\author{
Monograph \\ urn:lsid:zoobank.org:pub:F52DBAB0-38C7-400F-9BA1-E2D8E6B19E7E
}

\title{
Taxonomy and ontogeny of the Lituitida (Cephalopoda) from Orthoceratite Limestone erratics (Middle Ordovician)
}

\author{
Martina AUBRECHTOVÁ ${ }^{1, *}$ \& Dieter KORN ${ }^{\circledR 2}$ \\ ${ }^{1}$ Institute of Geology and Palaeontology, Faculty of Science, Charles University Prague, \\ Albertov 6, Prague, 12843, Czech Republic. \\ ${ }^{1}$ Institute of Geology, Czech Academy of Sciences, Rozvojová 269, Prague, 16500, Czech Republic. \\ ${ }^{2}$ Museum für Naturkunde, Leibniz-Institut für Evolutions- und Biodiversitätsforschung, \\ Invalidenstraße 43, 10115 Berlin, Germany. \\ ${ }^{*}$ Corresponding author: aubrech1@natur.cuni.cz, aubrechtova@gli.cas.cz \\ ${ }^{2}$ Email: dieter.korn@mfn.berlin \\ ${ }^{1}$ urn:lsid:zoobank.org:author:CAF4231-8787-4051-8D76-F983332517EE \\ ${ }^{2}$ urn:lsid:zoobank.org:author:286CA4F3-7EBC-4AEF-A66A-B2508D001367
}

\begin{abstract}
Ordovician ectocochleate cephalopods of the order Lituitida Starobogatov, 1983, mainly from erratics of the Orthoceratite Limestone embedded in Pleistocene glacio-fluvial sediments in Germany, Poland and the Kaliningrad Region of Russia are revised. In total, seven genera (Rhynchorthoceras, Ancistroceras, Angelinoceras, Holmiceras, Lituites, Trilacinoceras, Cyclolituites) and 28 species are identified. Eleven species are newly described: Rhynchorthoceras kranepuhlense sp. nov., $R$. rugium sp. nov., Holmiceras havelense sp. nov., Lituites baculus sp. nov., L. bottkei sp. nov., L. clavis sp. nov., L. dewitzi sp. nov., L. kruegeri sp. nov., L. nebeni sp. nov., Trilacinoceras filix sp. nov. and T. knoefleri sp. nov. The concept of several taxa described in the $19^{\text {th }}$ century, including the ambiguous species L. lituus de Montfort, 1808 and L. perfectus Wahlenberg, 1818, is refined. Neotypes are proposed for the latter two species.
\end{abstract}

Keywords. Lituitida, Orthoceratite Limestone, Middle Ordovician, ontogeny, intraspecific variation.

Aubrechtová M. \& Korn D. 2022. Taxonomy and ontogeny of the Lituitida (Cephalopoda) from Orthoceratite Limestone erratics (Middle Ordovician). European Journal of Taxonomy 799: 1-108.

https://doi.org/10.5852/ejt.2022.799.1681

\section{Introduction}

\section{General aspects}

Representatives of the Ordovician cephalopod order Lituitida Starobogatov, 1983 are among the iconic fossils of the Orthoceratite Limestone of Baltoscandia (Fig. 1). They were recognised already in the $18^{\text {th }}$ century because of their conspicuous conch shape, which resembles the "lituus", a curved Roman augur staff or war trumpet (Breyn 1732). Indeed, the conch of the genus Lituites Bertrand, 1763, and its type species L. lituus de Montfort, 1808, is coiled in its apical part, but only slightly curved or completely 
straight in the apertural part (Fig. 2). Another typical character is the strongly modified aperture, which forms ventral and lateral sinuses and deep and pronounced ventrolateral, dorsolateral and dorsal lappets. The shell surface is covered by a distinctive ornament consisting of sinuous annuli and lirae. The coiled and uncoiled parts of the phragmocone contain thick internal cameral deposits that can extend into the siphuncle through openings in the connecting rings.

Since the first description of $L$. lituus, many other lituitids expressing a wide range of conch morphologies have been recognised, e.g., Trilacinoceras Sweet, 1958, with a simplified, three-lappeted mature aperture, Angelinoceras Hyatt, 1894, with conspicuously large coiled conch, Cyclolituites Remelé, 1886, with a conch lacking the uncoiled part, Holmiceras Hyatt, 1894, and Ancistroceras Boll, 1857, with a rapidly expanding straight part of the conch, as well as Rhynchorthoceras Remelé, 1882, with a straight or only weakly cyrtoconic conch. The latter two genera comprise the stratigraphically oldest lituitids known to date (Fang et al. 2021).

Traditionally, the ancestry of the Lituitida has been sought among the coiled tarphyceratid or barrandeoceratid cephalopods (e.g., Flower 1955; Sweet 1958; Balashov 1962; Furnish \& Glenister 1964), but the morphology and stratigraphic occurrence of the earliest lituitids led to assumptions of orthoceratidan relationships (e.g., Schindewolf 1942; Dzik 1984; King 1999; Mutvei 2002; Kröger 2006; Kröger et al. 2007). Recently, Fang et al. (2021) and Pohle et al. (in press) proved that phylogenetic analyses can be successfully applied to Palaeozoic non-ammonoid cephalopods including lituitids; their results supported orthoceratidan (or at least orthoceratoid) relationships of the lituitids. This view is also followed in the present paper; for a further discussion of the phylogenetic relationships of the Lituitida, see the summary provided by King \& Evans (2019).

Although the Lituitida is a distinctive order of cephalopods with a good fossil record, the separation of individual species has always been problematic due to the existence of transitional morphologies and uncertainties about the taxonomic significance of individual characters. Moreover, it was further complicated by the incomplete preservation of nearly all of the specimens, which also includes the type material (discussion in Aubrechtová \& Meidla 2020). Because of these problems, we use the full set of characters (see below) here for the taxonomic treatment of the material.

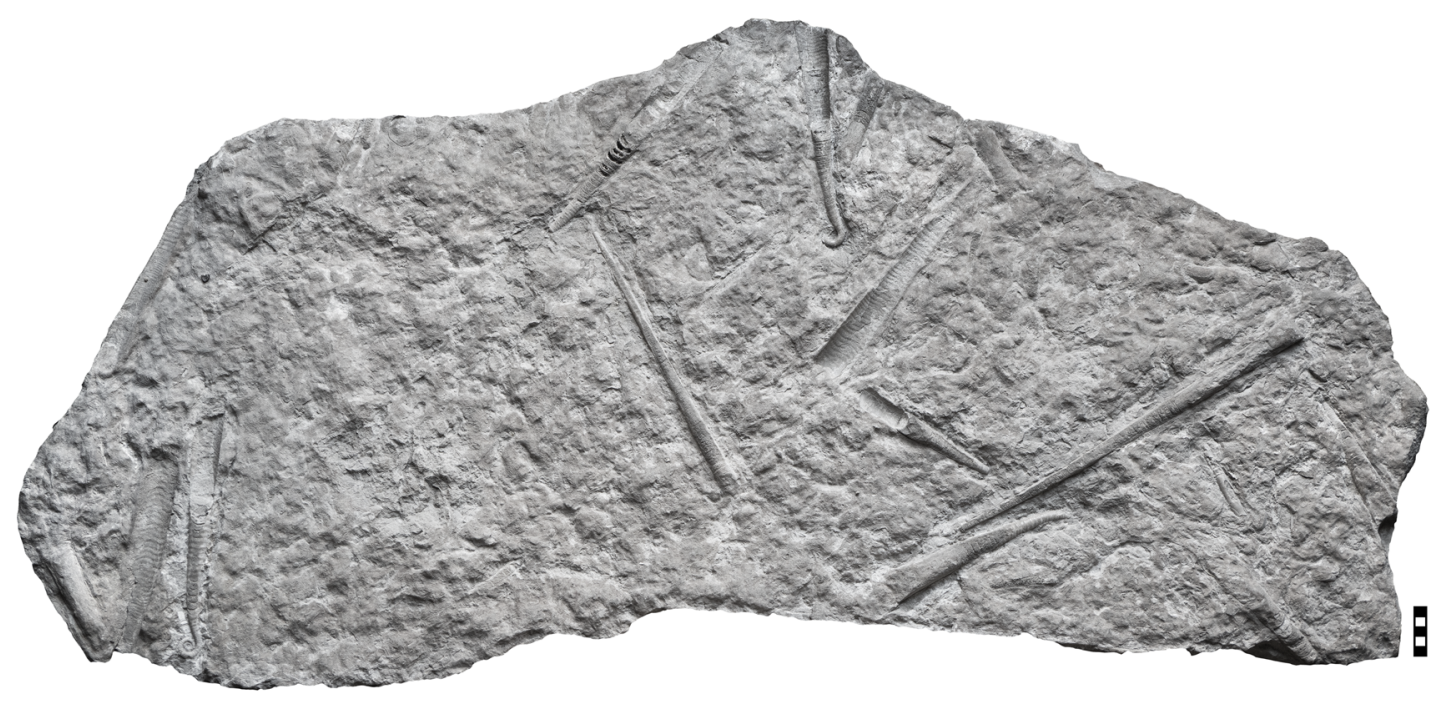

Fig. 1. Large slab of the Upper Grey Orthoceratite Limestone (late Darriwilian, Middle Ordovician) with scattered conchs of lituitid and orthoceratid cephalopods, sample MB.C.30490 from the Island of Öland (Sweden). Scale bar units $=10 \mathrm{~mm}$. 
Most species of Baltoscandian lituitids were described in the second half of the $19^{\text {th }}$ century (e.g., Boll 1857; Angelin 1880; Dewitz 1880; Remelé 1880, 1882, 1890; Holm 1891; Hyatt 1894) and are often known only from unrevised type collections. Some detailed taxonomic works on Baltoscandian lituitids were published later (Foerste 1930; Balashov 1953; Sweet 1958; Furnish \& Glenister 1964; Dzik 1984; Aubrechtová \& Meidla 2020), while numerous lituitid taxa were described from other regions, especially China (e.g., Lai 1965, 1986; Qi 1980; Fang et al. 2017). In Baltoscandia and China, the lituitids have been used as low-resolution biostratigraphic indicators (e.g., Jaanusson \& Mutvei 1953; Jaanusson 1960; Lai 1989; Xiao et al. 2006; Evans et al. 2014).

In the present study, we revise the Baltoscandian lituitids based on historical and more recent collections, mainly from the Middle Ordovician (Darriwilian) erratics in Pleistocene glacio-fluvial sediments in Germany and Poland, including type specimens of several species. The studied collection included also specimens from in-situ occurrences in Sweden (including the Island of Öland), Estonia and Norway. In addition to the material from Baltoscandia, one additional specimen was identified in the collections that originates from the brown limestone of the Datianba Formation (Middle or Late Ordovician) of the Songtao County (Guizhou, South China); this specimen was added to the study due to its exceptionally complete preservation. We further discuss the taxonomy and investigate the ontogenetic variation in some lituitid taxa.
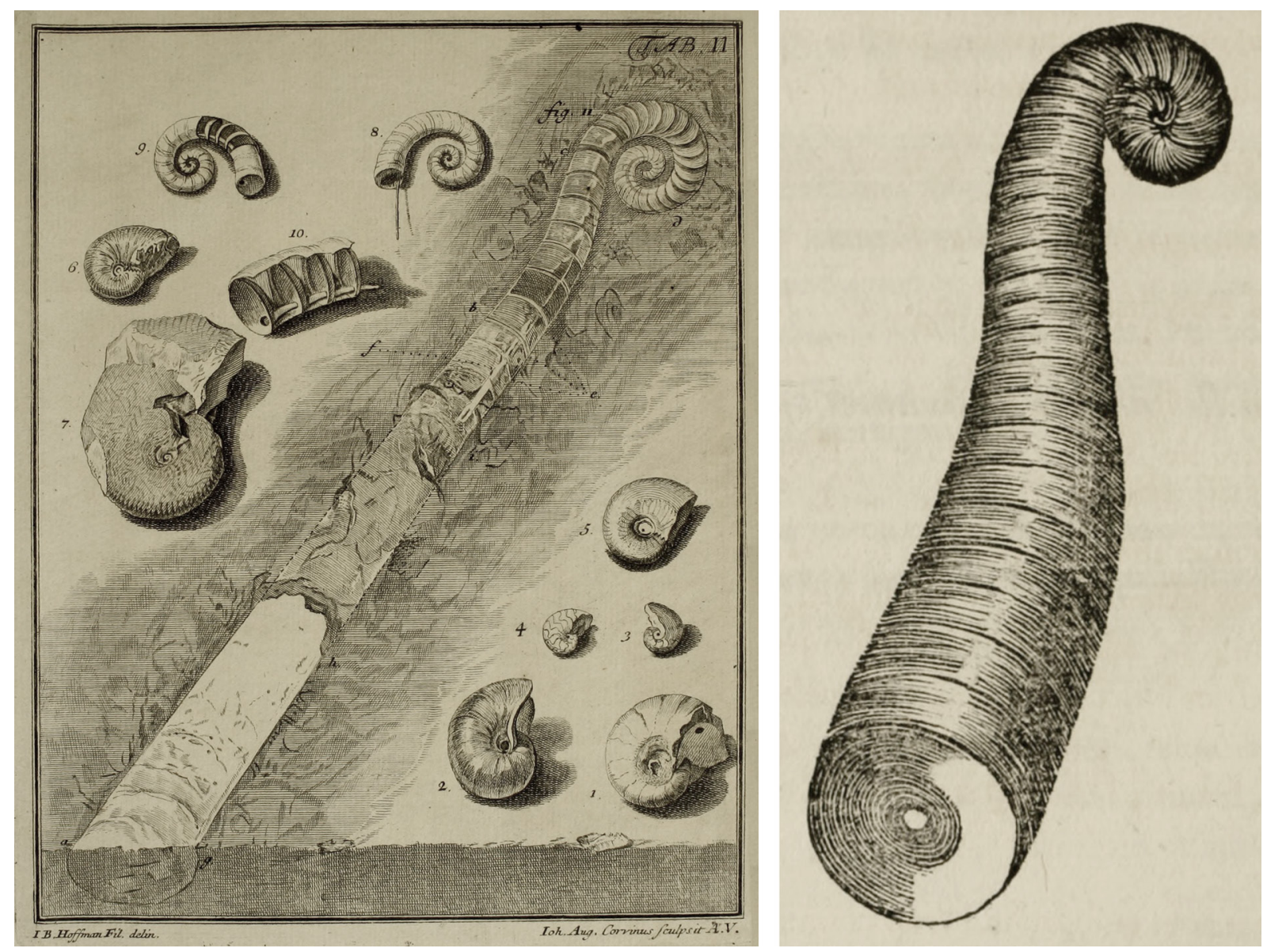

Fig. 2. Historical illustrations of Lituites specimens of Breyn (1732) (left) and de Montfort (1808) (right). 


\section{Geological and stratigraphic outline}

The Middle and Late Ordovician Orthoceratite Limestone is a succession of thin-bedded, condensed, cool-water carbonate sedimentary rocks that were deposited in an epicontinental sea on the continental margin of Baltica (Schmitz et al. 1996; Lindskog \& Eriksson 2017; Lindskog et al. 2020). Due to the gentle dipping of the marginal platform, the transport of weathering products was reduced; sedimentation was extremely slow, with recurring sedimentation breaks, development of hard-grounds and prolonged phases of erosion (e.g., Lindström 1971, 1979; Jaanusson 1973, 1982; Schmitz et al. 1996; Dronov \& Holmer 1999; Ekdale \& Bromley 2001; Lindskog et al. 2017). The character and distribution of the numerous facies of the Orthoceratite Limestone was strongly influenced by local bathymetric conditions, eustatic sea-level changes and the gradual drift of Baltica towards equatorial latitudes (Jaanusson 1973, 1982; Dronov \& Holmer 1999; Cocks \& Torsvik 2005; Dronov \& Rozhnov 2007; Dronov et al. 2011; Bergström et al. 2013; Torsvik \& Cocks 2017).

The Orthoceratite Limestone has a wide geographic distribution across Baltoscandia. It commonly occurs as erratic boulders within Pleistocene glacial and glacio-fluvial sediments in Western, Central and Eastern Europe. Research on erratic blocks in these regions has a long tradition and contributed substantially to the knowledge on the Orthoceratite Limestone in the source areas (Sendino \& Bochmann 2021).

Parts of the Orthoceratite Limestone succession are well-known to yield abundant and well-preserved body fossils, for example brachiopods (e.g., Rasmussen et al. 2009), ostracods (Tinn \& Meidla 2001; Tinn et al. 2006), molluscs (e.g., Lindskog et al. 2015; Sendino \& Bochmann 2021) as well as trace fossils (Toom et al. 2019). The most important index macrofossils of the Orthoceratite Limestone are trilobites (Pärnaste \& Bergström 2013; Pärnaste et al. 2013) and orthoconic cephalopods (King 1999; Kröger 2004b, 2006, 2012). The fossil content of the Orthoceratite Limestone, together with lithological features, enable the determination of the source areas and stratigraphic levels of erratic boulders (e.g., Remelé 1883; Hucke 1967; Neben \& Krueger 1971; Dzik \& Kiselev 1995; Malinky 2007; Maletz \& Schöning 2017).

The variable facies characters of the Orthoceratite Limestone cause some difficulties in correlation between individual confacies belts (Jaanusson 1976); hence, separate stratigraphic scales for the in-situ Orthoceratite Limestone occurrences were used in the western, central and eastern areas of Baltoscandia (Dronov \& Holmer 1999; Kröger 2004b; Ebbestad \& Högström 2007; Malinky 2007; Pärnaste et al. 2013; Sendino \& Bochmann 2021) and for the erratics (Hucke 1967; Neben \& Krueger 1971). However, recent research has enabled the unification of the Baltoscandian stratigraphic scheme and correlation with the global chronostratigraphic standard (e.g., Nõlvak et al. 2006; Bergström et al. 2009). This has been achieved mainly by the application of chemostratigraphic methods (e.g., Ainsaar et al. 2007, 2010; Bergström et al. 2015), conodont and graptolite biostratigraphic data (e.g., Bergström 2007a, 2007b; Bergström \& Löfgren 2008) and their integration (e.g., Wu et al. 2018).

\section{Material and methods}

\section{Studied material}

The present study is based on a total of 249 specimens of lituitid cephalopods (Supp. file 1, Supp. file 2) kept in the fossil invertebrate collection of the Museum für Naturkunde, Berlin (MB.C. prefix). The examined specimens were found in boulders of the Middle Ordovician Orthoceratite Limestone erratics embedded in Pleistocene glacio-fluviatile sediments in northern Germany, Poland and the Kaliningrad Region of Russia. Twenty-three specimens come from in-situ limestones at localities in Sweden (including the Island of Öland), Estonia and Norway (Fig. 3). An additional specimen (MB.C.29655) from the brown limestone of the Datianba Formation (Middle or Late Ordovician) of the Songtao County 
(Guizhou, South China) was included in the study, as well, because the preservation of the conch is exceptionally complete and enables direct comparisons with the Baltoscandian material.

Almost $50 \%$ of the specimens were collected at localities near Eberswalde (Brandenburg, Germany; Fig. 3B), where they came from erratic boulders of middle and/or late Darriwilian age. This leads to some collection and stratigraphy bias in the record, although the prevalence of specimens of the genera Lituites (42\% of all specimens) and Rhynchorthoceras (30\%) agrees with their general high abundance
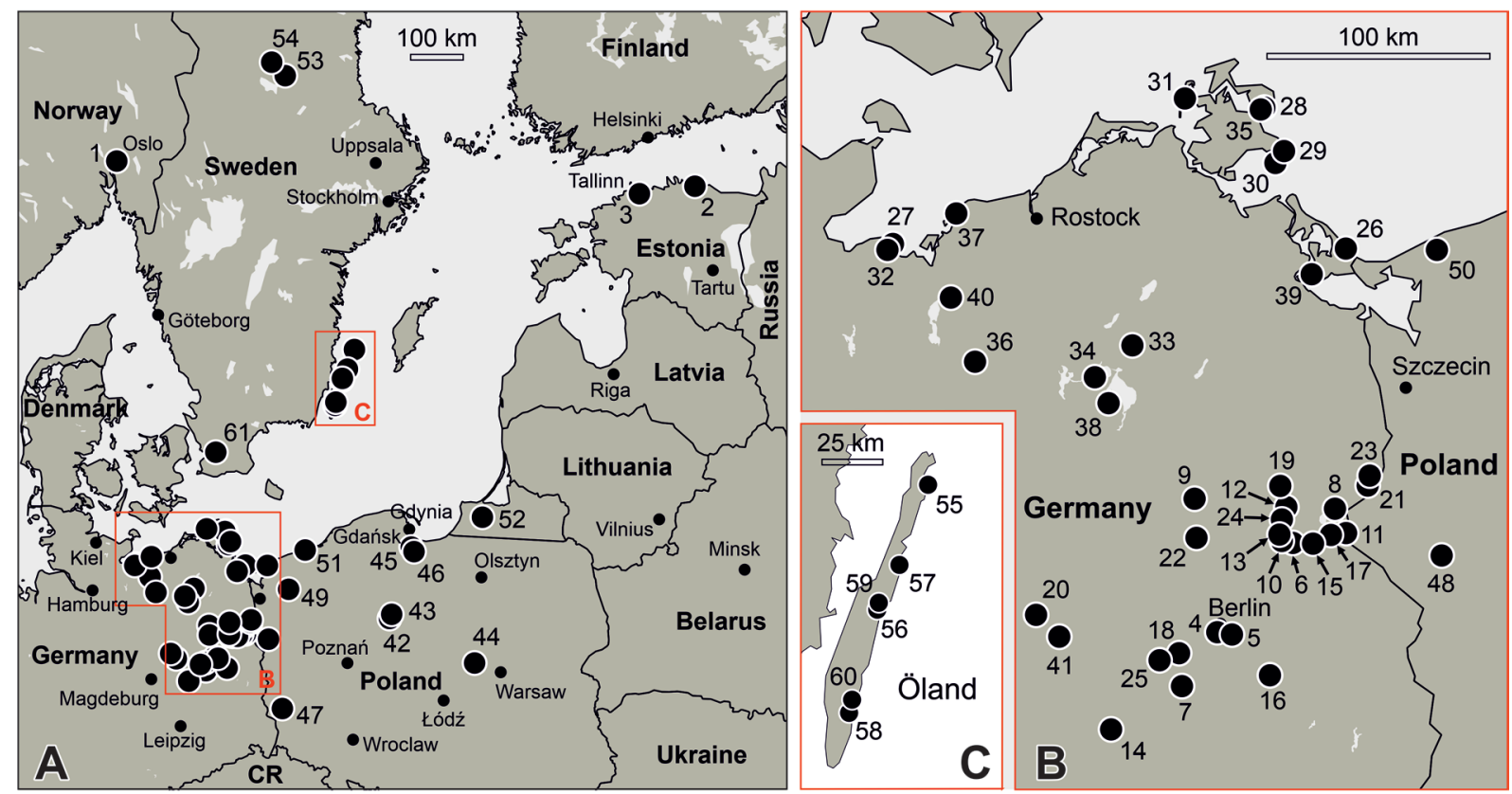

Fig. 3. A. Map with localities from which the herein studied specimens originated. B. Localities in north-eastern Germany and western Poland. C. Localities in the Island of Öland (Sweden). Map prepared using the QGIS software (using the open-source World Map, OpenStreetMap and "WISE Large rivers and large lakes F1v1 geodatabase" of the European Environment Agency). Number coding of localities: Norway: 1 - Oslo (former Christiania); Estonia: 2 - Karula (Lääne-Viru County), 3 Tallinn (former Reval, Harju County); Germany, Berlin: 4 - Schmargendorf, 5 - Tempelhofer Feld; Germany, Brandenburg: 6 - Eberswalde, 7 - Fresdorf, 8 - Gellmersdorf (Angermünde), 9 - Gransee (Ruppin), 10 - Heegermühle, 11 - Hohensaaten, 12 - Joachimsthal, 13 - Karlsröhe (Lichterfelde, Eberswalde), 14 - Kranepuhl, 15 - Niederfinow, 16 - Niederlehme, 17 - Oderberg, 18 - Potsdam, 19 - Ringenwalde, 20 - Schmetzdorf, 21 - Schwedt, 22 - Teschendorf (Löwenberg), 23 - Vierraden (Schwedt), 24 - Werbellinsee, 25 - Werder (Potsdam); Germany, Mecklenburg-Vorpommern: 26 Bansin (Usedom), 27 - Boltenhagen (Gross Klütz Höved), 28 - Dwasieden (Rügen), 29 - Göhren, 30 Groß Zicker (Rügen), 31 - Hiddensee Island, 32 - Klütz Höved, 33 - Lansen (Malchin), 34 - Lebbin, 35 - Mukran (Sassnitz, Rügen), 36 - Neu-Ruthenbeck (Parchim), 37 - Rerik, 38 - Röbel, 39 - Usedom, 40 - Ventschow; Germany, Saxony-Anhalt: 41 - Schlagenthin; Poland, Kujawi-Pomerania: 42 Bydgoszcz (former Bromberg), 43 - Osielsk (Bydgoszcz); Poland, Masovia: 44 - Czerwińsk; Poland, Pomerania: 45 - Juszkowo (former Gischkau), 46 -Skowarcz (former Schönwarling); Poland, Silesia: 47 - Żory (former Sorau); Poland, West Pomerania: 48 - Barnówko (former Berneuchen), 49 - Dewitz Castle (Dobra, former Dewitzburg bei Daber), 50 - Chrząszczewska Island (former Gristow), 51 Ustronie Morskie (former Henkenhagen); Russia: 52 - Kaliningrad; Sweden, Dalarna: 53 - Fjecka (Boda), 54 - Skattungbyn; Sweden, Öland: 55 - Böda Hamn, 56 - Gärdslösa, 57 - Kårehamn, 58 Skärlöv, 59 - Tjusby, 60 - Triberga; Sweden, Skåne: 61 - Södra Sandby. 
in Middle Ordovician strata of Baltoscandia and China. Other genera identified in the collection include Ancistroceras (ca 16\% of all specimens), Trilacinoceras (5\%), Angelinoceras (3\%), Cyclolituites (2\%) and Holmiceras (one single specimen).

A total of seven lituitid genera and 28 species were identified, eleven species are newly described below. Only four specimens could not be determined at the genus level, while 109 specimens (44\%) of all investigated specimens were determined at genus level but not at species level. The highest proportion of unidentifiable specimens is in the genus Ancistroceras (68\%), followed by Lituites (63\% of all specimens) and Rhynchorthoceras (19\%). The relatively high proportion of unidentifiable specimens in these genera is the result of fragmentary preservation, as diagnostic characters in many lituitid species are related to the coiled part of the conch.

The stratigraphic positions of the specimens were inferred from information on museum labels, as well as from the lithology and accompanying fossils (e.g., Jaanusson \& Mutvei 1953; Jaanusson 1960, 1963; Hucke 1967; Neben \& Krueger 1971, 1973; Ebbestad \& Högström 2007). In most cases, it was possible to reliably assign the specimens to regional Baltoscandian and global stages (Supp. file 1, Fig. 4).

Most of the specimens are isolated fragments of coiled or uncoiled parts of the conchs. The specimens are not significantly deformed or corroded, but the initial and apertural parts of the conchs are usually broken off. The shell ornament is generally well preserved; in some cases, the shell surface bears shallow, irregular pits resembling structures described by Pohle et al. (2019); the authors listed local, post-mortem dissolution of the shell and the role of bacteria or fungi among the possible explanations for the origin of these pits.

Along with photographs, we have reproduced illustrations of some of the specimens described by Angelin (1880), Noetling (1882, 1884), Remelé (1890), Holm (1891) and Dzik (1984) because these are very accurate and show additional details of the conch morphology.

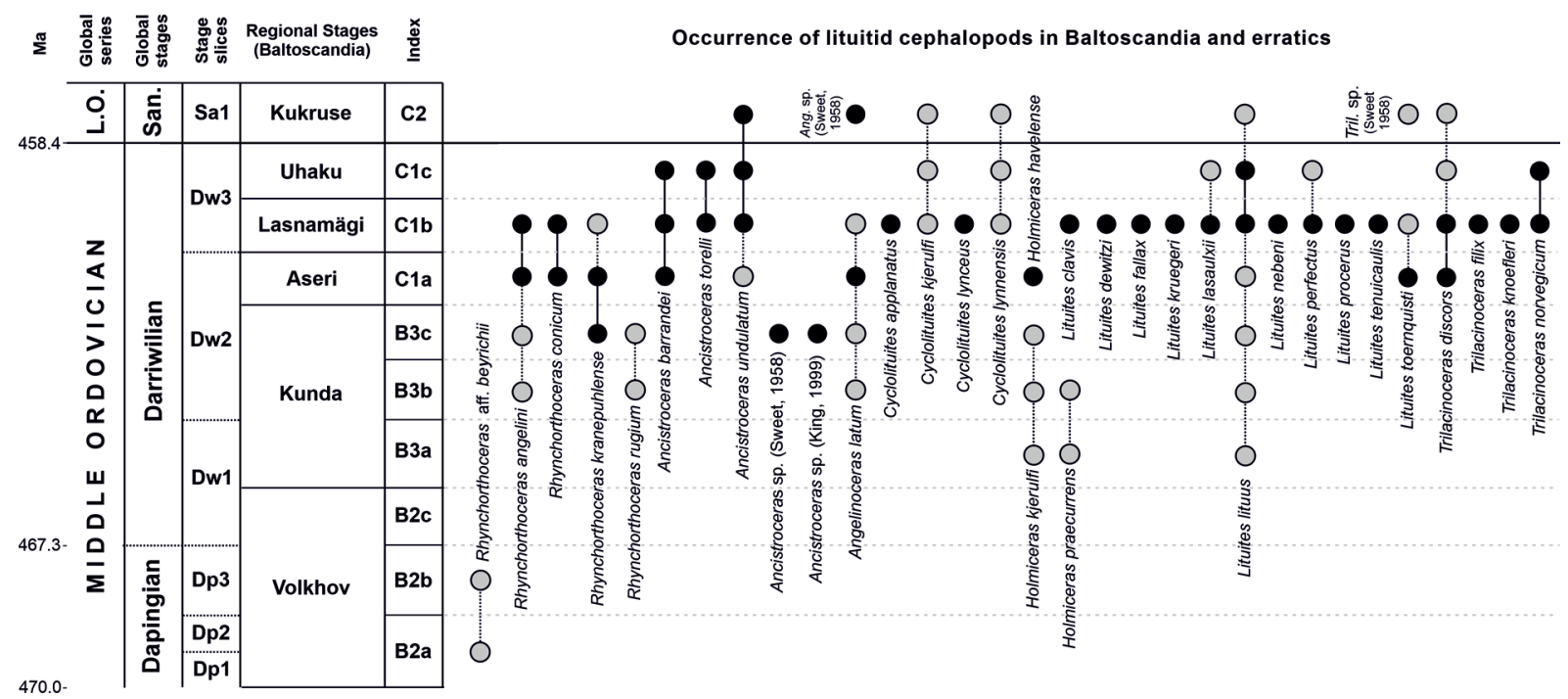

Fig. 4. Stratigraphic distribution of lituitid taxa in Ordovician strata of Baltoscandia and Ordovician erratics; black circles indicate unambiguous presence, grey circles indicate possible presence. Species with unknown stratigraphic occurrence are excluded from the scheme. Stratigraphic chart after Ebbestad \& Högström (2007) and Meidla et al. (2014); stage slices after Bergström et al. (2009). 
Macrofossils accompanying the lituitid specimens include endoceratid, orthoceratid and tarphyceratid cephalopods, asaphid, cheirurid, illaenid and lichid trilobites, gastropods of the genera Clathrospira Ulrich \& Scofield, 1897 and Lesueurilla Koken, 1898, rhynchonellid brachiopods of the genus Porambonites Pander, 1830 and hyoliths. Holdfasts of stalked echinoderms are attached to the shell surfaces in sixteen cephalopod specimens (Fig. 5). Ichnofossils are represented in eight cephalopod specimens by small (ca $1 \mathrm{~mm}$ in diameter), circular borings (possibly Trypanites Mägdefrau, 1932), which are either scattered on the shell surface or located on the concave surface of septa, where they are concentrated around the septal foramen (MB.C.11700). The internal mould of specimen MB.C.11629 bears burrows attributable to the ichnogenus Arachnostega Bertling, 1992. The shells of eight cephalopod specimens bear healed injuries (Fig. 6); similar damages have been reported before and interpreted as likely caused by a predatory attack during the animal's life (Kröger 2004a; Klug 2007).
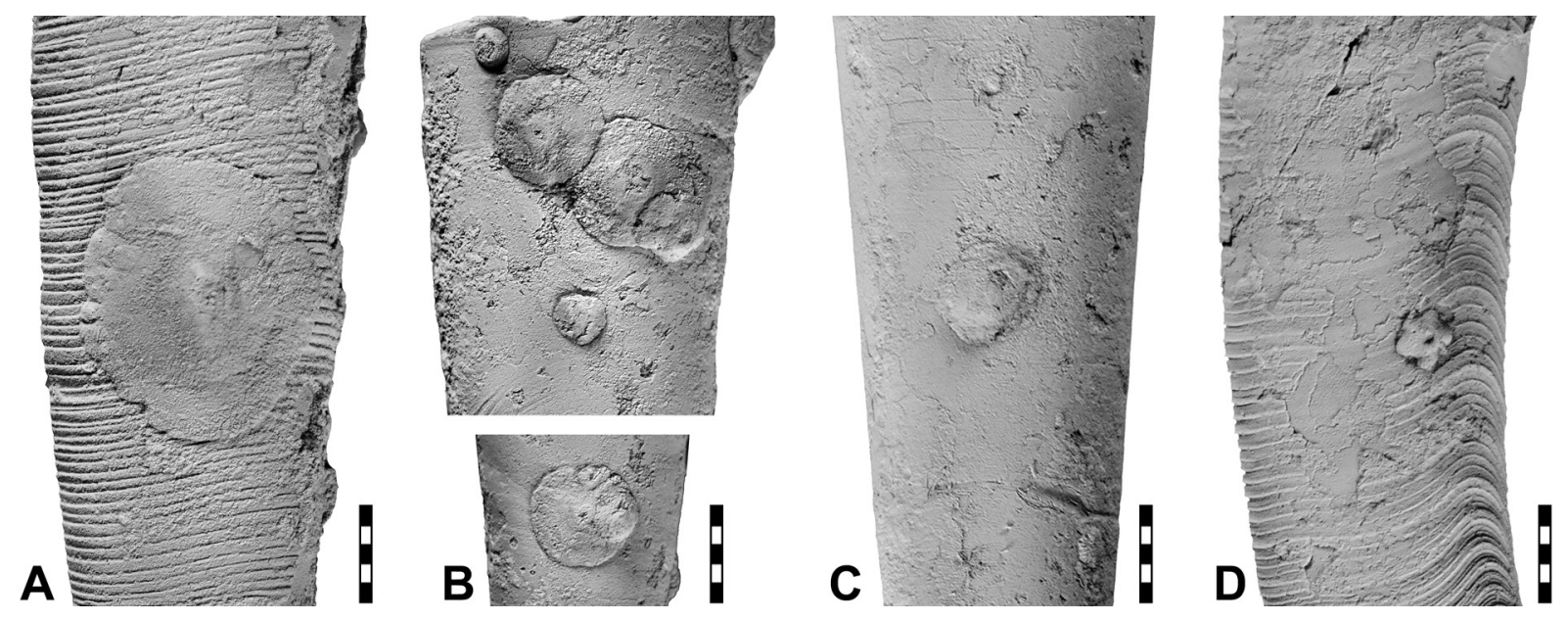

Fig. 5. Echinoderm holdfasts on shells of lituitid specimens. A. Rhynchorthoceras angelini (Boll, 1857), specimen MB.C.11727 (Schmidt Coll.) from near Berlin-Schmargendorf. B. Rhynchorthoceras conicum (Hisinger, 1837), specimen MB.C.30508 from Dewitz Castle, Dobra (former Dewitzburg bei Daber; West Pomerania, Poland). C. Rhynchorthoceras rugium sp. nov., holotype MB.C.11728 (Hoffmann \& Gager 1972 Coll.) from Mönchgut (Island of Rügen). D. Trilacinoceras knoefleri sp. nov., paratype MB.C.30559 (Krueger Coll.) from Mukran (Sassnitz, Island of Rügen) (Mecklenburg-Vorpommern). Scale bar units $=1 \mathrm{~mm}$.
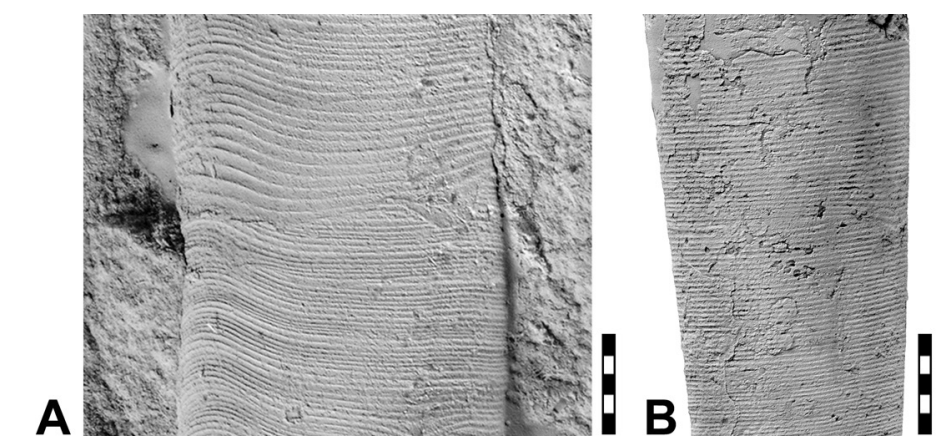

Fig. 6. Shell injuries of lituitid specimens (shown in the centre to the right in both A and B). A. Lituites bottkei sp. nov., holotype MB.C.29651 (Bottke Coll.) from Gärdslösa (Island of Öland, Sweden). B. Rhynchorthoceras angelini (Boll, 1857), specimen MB.C.29656 (Bottke Coll.) from Skärlöv (Island of Öland). Scale bar units $=1 \mathrm{~mm}$. 


\section{Morphological terminology}

The terminology used here to describe lituitid conchs is based on the work of Furnish \& Glenister (1964) and Flower (1964). The morphology of the coiled part of the conchs was quantified using parameters and ratios defined by Korn \& Klug (2003) and Korn (2010) for ammonoids, while the terminology of shell ornament follows Kröger (2008) and Klug et al. (2015). The used terminology is summarised in Table 1 and Fig. 7.

Below follows a short explanation of the terms used:

\section{Conch shape}

The lituitid conch is divided into three parts:

- coiled (juvenile) part - it consists of several, more or less tightly coiled, volutions (in the representatives of the family Sinoceratidae, the apical part of the conch is not coiled but cyrto- or orthoconic);

- backcoiled (preadult) part - the conch shows inverted coiling direction;

- straight (adult) part - conch part without coiling.

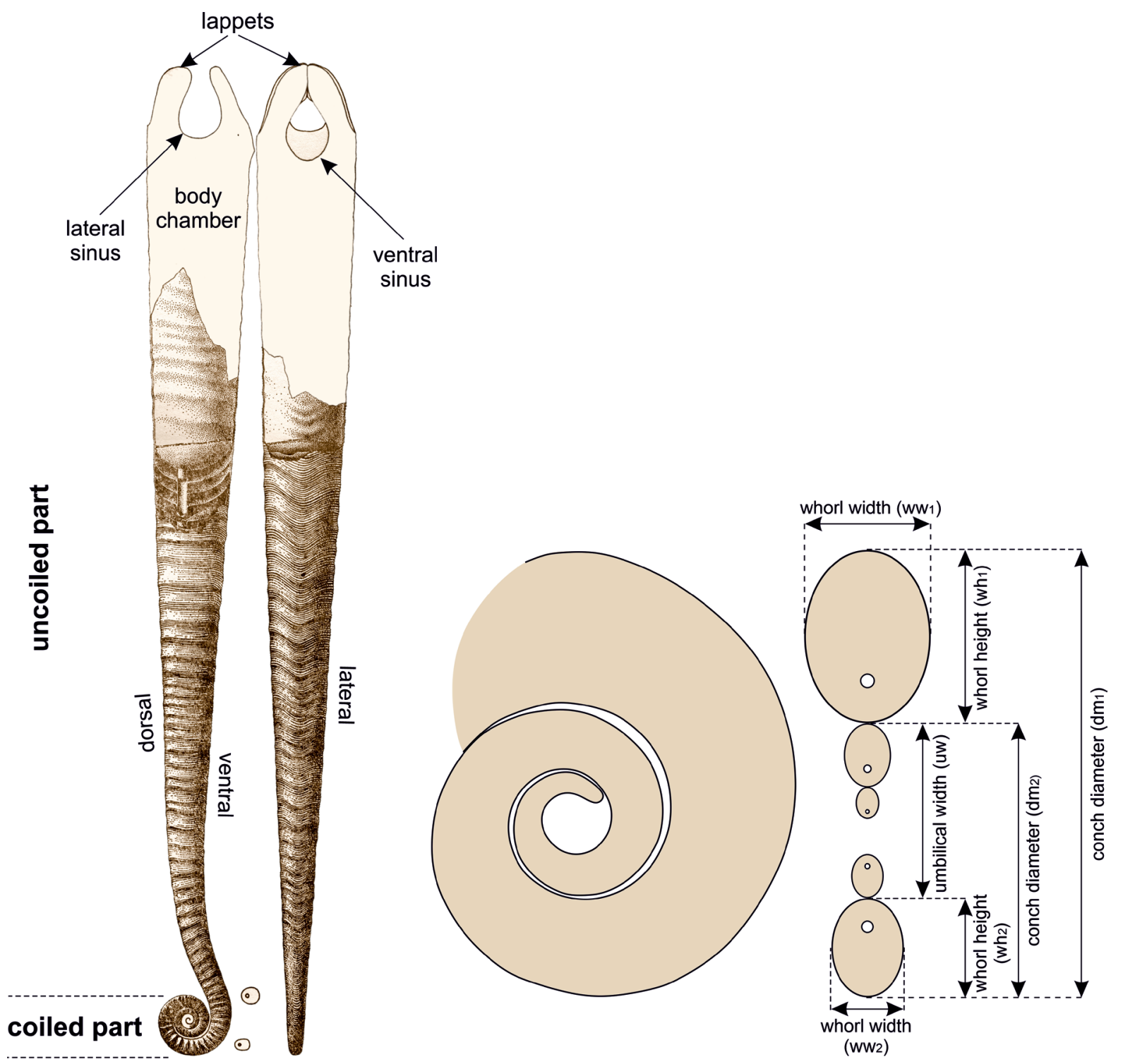

Fig. 7. Morphological terminology used in this study to describe lituitid specimens; drawing from Dzik (1984). 
Table 1. Terminology for the description of the specimens of lituitid cephalopods.

\begin{tabular}{|c|c|c|}
\hline Parameter [unit] & Abbreviation & Calculation \\
\hline conch diameter $[\mathrm{mm}]$ & $\mathrm{dm}$ & \\
\hline whorl height [mm] & wh & \\
\hline whorl width [mm] & ww & \\
\hline umbilical width $[\mathrm{mm}]$ & uw & $\mathrm{dm}_{1}-\mathrm{wh}_{1}-\mathrm{wh}_{2}$ \\
\hline apertural height [mm] & ah & \\
\hline interspace width & iw & $\left(\mathrm{dm}_{1}-\mathrm{dm}_{2}-\mathrm{wh}_{1}\right) / \mathrm{wh}_{1}$ \\
\hline whorl expansion rate (outline) & WERdm & $\left(\mathrm{dm}_{1} / \mathrm{dm}_{2}\right)^{2}$ \\
\hline whorl expansion rate apertural height) & WERah & {$\left[\mathrm{dm}_{1} /\left(\mathrm{dm}_{1}-\mathrm{ah}\right)\right]^{2}$} \\
\hline umbilical width index & UWI & $\mathrm{uw} / \mathrm{dm}$ \\
\hline whorl width index & WWI & ww/wh \\
\hline angle of expansion $\left[{ }^{\circ}\right]$ & EA & $\begin{array}{l}2 *((\operatorname{arctangens}(((\mathrm{d}- \\
\max -\mathrm{dmin}) / 2) / \mathrm{h})) * 180) / \pi\end{array}$ \\
\hline chamber length ratio & CLR & chamber length/wh \\
\hline siphuncule diameter $[\mathrm{mm}]$ & sd & \\
\hline siphuncular diameter ratio & SDR & $\mathrm{sd} / \mathrm{wh}$ \\
\hline siphuncle distance $[\mathrm{mm}]$ & $\mathrm{sp}$ & \\
\hline siphuncular position ratio & SPR & $\mathrm{spr} / \mathrm{wh}$ \\
\hline
\end{tabular}

The backcoiled and straight parts are collectively referred to as "uncoiled part" when a particular character applies to both conch parts. In some representatives of the family Lituitidae Phillips, 1848, such as the genus Ancistroceras, a backcoiled part is lacking; in the species of the genus Cyclolituites of the family Lituitidae, the uncoiled part of the conch is not developed, and the conch remains coiled through ontogeny.

For the description of the general geometry of the uncoiled conch, the expansion rate of the conch is used:

$$
\mathrm{EA}=\text { expansion angle }\left(\text { in }^{\circ}\right)
$$

For the description of the whorl profile, the terms whorl height (wh), apertural height (ah, which is identical with the whorl height in openly coiled conchs) and whorl width (ww) are used for both the coiled and uncoiled parts of the conch (including in Rhynchorthoceras, which lacks the coiled part). The umbilical width (uw) refers to the coiled conchs. The size of the coiled conch is measured by its diameter $(\mathrm{dm})$. In the descriptions, the following indexes are used:

$$
\begin{aligned}
& \mathrm{UWI}=\text { umbilical width index }=\mathrm{uw} / \mathrm{dm} \\
& \mathrm{WWI}=\text { whorl width index }=\mathrm{ww} / \mathrm{wh}
\end{aligned}
$$

We used two measurements of the whorl expansion rate (WER) to distinguish between the mode of coiling and the actual expansion of the conch:

$\mathrm{WER}_{\mathrm{dm}}=$ coiling rate calculated with the diameter of the conch $=\left(\mathrm{dm}_{1} / \mathrm{dm}_{2}\right)^{2}$; this describes the opening rate of the whorls along the venter; 
$\mathrm{WER}_{\mathrm{ah}}=$ coiling rate calculated with the apertural height $(\mathrm{ah})$ of the conch $=\left(\mathrm{dm}_{1} /\left(\mathrm{dm}_{1}-\mathrm{ah}_{1}\right)\right)^{2}$; this describes the expansion rate of the whorl tube that accommodates the soft body. Note that in lituitid cephalopods the apertural height equals the whorl height.

For tightly coiled conchs, the distinction is unnecessary because both modes lead to the same result; then the whorl expansion rate WER is given without an index.
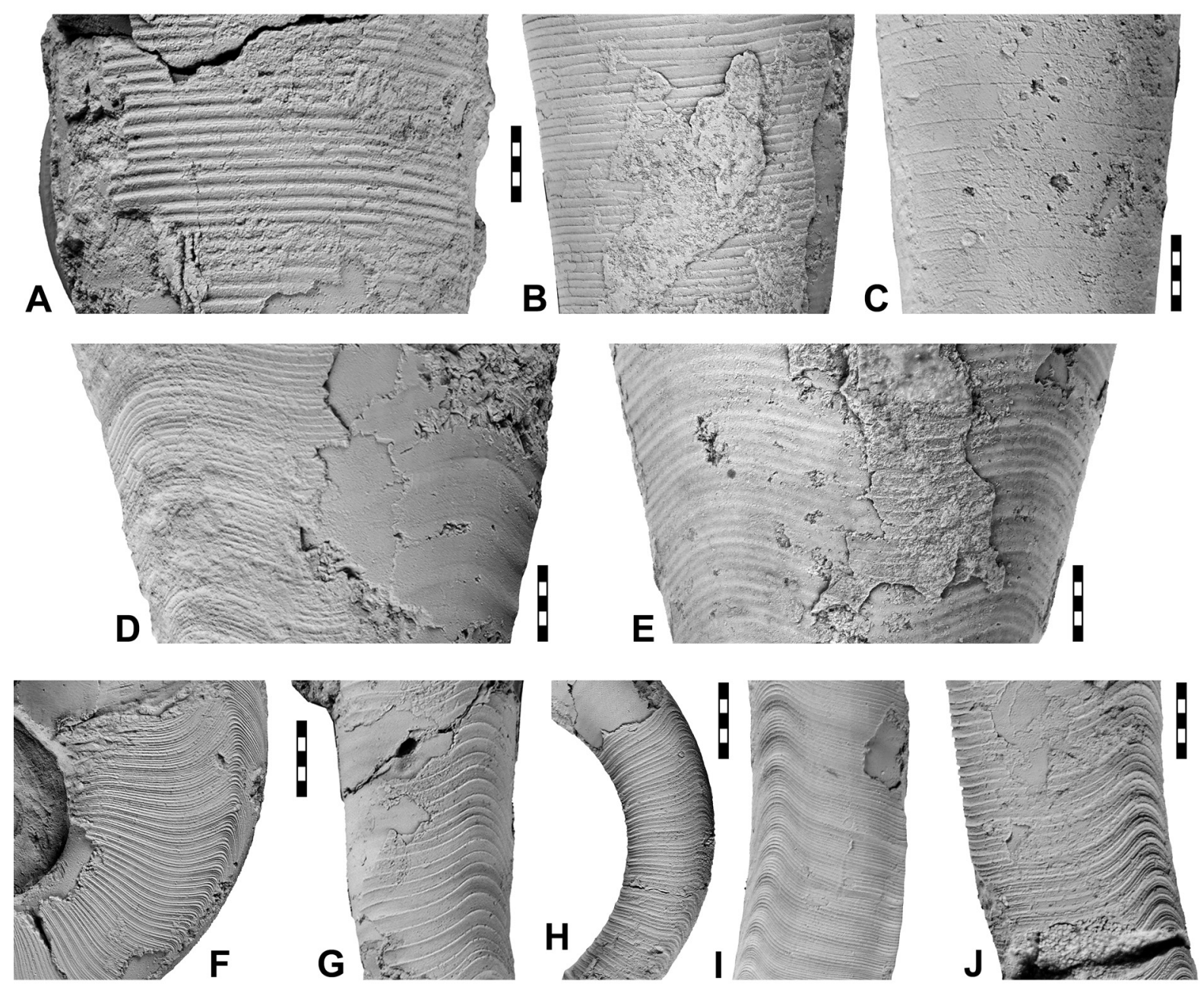

Fig. 8. Ornament details of lituitid specimens. A. Coarse lirae, symmetric crests; Rhynchorthoceras angelini (Boll, 1857), specimen MB.C.30495.1. B. Coarse lirae, asymmetric crests; R. angelini (Boll, 1857), specimen MB.C.11716. C. Faint, widestanding striae; R. rugium sp. nov., holotype MB.C.11728. D. Lirae and almost smooth internal shell; Ancistroceras torelli (Remelé, 1881), specimen MB.C.30519. E. Lirae and undulated internal shell; A. undulatum (Boll, 1857), specimen MB.C.11697. F. Narrow annuli, raised lirae and growth lines; Cyclolituites applanatus (Remelé, 1880), specimen MB.C.30560. G. Wide-standing, prorsiradiate lirae and very fine growth lines; Lituites dewitzi sp. nov., holotype MB.C.30538. H. Sharp lirae, straight on the flanks; L. fallax Remelé, 1890, holotype MB.C.11672.2. I. Sharp, prorsiradiate lirae and flat annuli; L. kruegeri sp. nov., holotype MB.C.30539. J. Wide-standing, sharp lirae and very flat annuli, straight on the flanks; Trilacinoceras knoefleri sp. nov., paratype MB.C.30559. Scale bar units $=1 \mathrm{~mm}$. 


\section{Chambers}

The distance of the septa is expressed as the relative length of phragmocone chambers as the chamber length ratio: $\mathrm{CLR}=$ length of the phragmocone chamber divided by the whorl height of the chamber.

\section{Siphuncle}

We refer to the relative size and position of the siphuncle using two ratios:

- $\mathrm{SDR}=$ siphuncular diameter ratio: dorso-ventral width of the septal foramen divided by the corresponding whorl height;

- $\mathrm{SPR}=$ siphuncular distance ratio: distance of the centre of the siphuncle from the dorsal shell wall divided by the corresponding whorl height.

\section{Shell ornament}

We distinguish between the following elements to describe the shell ornament:

- growth lines - the finest ornament, formed by the discontinuous secretion of the shell at the aperture (Klug et al. 2015) (Fig. 8F-G);

- lirae - transverse raised lines, coarser than growth lines and sometimes formed by a dense amalgamation of growth lines; transverse profile of lirae may be symmetric (Fig. 8A, D-I) or asymmetric (Fig. 8B);

- ribs - coarse transverse ornament, which may be limited to certain part of the conch circumference, usually to the flanks;

- annuli - transverse rings around the whole conch circumference, formed either by shell wall thickening or shell wall undulation (Fig. 8F, I-J);

- striae - minute transverse grooves (Fig. 8C).

The direction of ornament elements is classified as:

- rursiradiate $=$ general backward direction;

- rectiradiate $=$ general radial direction;

- prorsiradiate $=$ general forward direction .

The course of ornament elements is classified as:

- linear = with no remarkable projections and sinuses;

- convex = with only one wide lateral projection and a ventral sinus;

- concavo-convex = with a lateral sinus, ventrolateral projection and a ventral sinus;

- biconvex = with dorsolateral projection, a lateral sinus, a ventrolateral projection and a ventral sinus.

The measured parameters and ratios were plotted in diagrams to show changes of the characters through ontogeny. The logarithmic scale was used in the diagrams to account for the exponential conch size growth; the logarithmic scale was used also in the case of uncoiled conch parts and orthoconic conchs for consistency and to enable comparisons. In the illustrations of the growth lines, the arrow indicates the position of the middle of the venter, the double line the position of the middle of the dorsum. 


\section{Results}

Phylum Mollusca Linnaeus, 1758

Class Cephalopoda Cuvier, 1797

Order Lituitida Starobogatov, 1983

\section{Diagnosis}

Cephalopods with longiconic orthoconic or weakly cyrtoconic conchs, with cyrtoconic or coiled apical part. Siphuncle tubular, narrow (up to 0.20 of whorl height). Septal necks straight (orthochoanitic), rarely cyrtochoanitic in apical conch parts, and long (usually $0.25-0.30$ of chamber length but over 0.50 in some taxa). Connecting rings often disaggregated and covered with cameral deposits that extend to cover the septal neck and inner parts of the connecting ring. Cameral deposits often consist of longitudinal lamellae or sheets that longitudinally divide chambers. Initial chamber small (length = $0.4 \mathrm{~mm}$ ), subspherical, without cicatrix (after Kröger et al. 2007, emended).

Family Sinoceratidae Shimizu \& Obata, 1935

\section{Diagnosis}

Family of the order Lituitida with orthoconic or cyrtoconic apical part of the conch. Whorl profile elliptical to circular. Shell surface smooth or ornamented with growth lines and transverse lirae or striae; ventral sinus of ornament elements weakly developed. Siphuncle subcentral or central in position, septal necks orthochoanitic but sometimes cyrtochoanitic in the apical part (after Dzik 1984 and Kröger et al. 2007, emended).

\section{Genera included}

Rhynchorthoceras Remelé, 1882; Sinoceras Shimizu \& Obata, 1935; Tyrioceras Strand, 1934.

Genus Rhynchorthoceras Remelé, 1882

\section{Type species}

Lituites Breynii Boll, 1857; subsequent designation by Furnish \& Glenister (1964).

\section{Diagnosis}

Genus of the family Sinoceratidae with orthoconic, longiconic conch, slightly curved in the apical part; expansion angle between $8^{\circ}$ and $17^{\circ}$; whorl profile circular or compressed. Shell surface smooth or decorated with transverse lirae or striae. Siphuncle ca 15\% of whorl height, central or subcentral in position, displaced towards the convex side of the conch; septal necks orthochoanitic, connecting rings tubular or slightly expanded within chambers. Cameral deposits with single vertical lamellae on the concave side of the conch (after Kröger et al. 2007, emended).

\section{Species included}

Lituites angelini Boll, 1857; Rhynchorthoceras Beyrichii Remelé, 1882; Lituites Breynii Boll, 1857; Rhynchorthoceras blackduckense Stait, 1988; Rhynchorthoceras concavum Lai \& Wang, 1986; Orthoceratites conicus Hisinger, 1837; Cyrtoceras damesi Dewitz, 1879; Rhynchorthoceras guanyinqiaoense Lai, 1986; Rhynchorthoceras helgoeyense Sweet, 1958; Rhynchorthoceras jurongense Zou, 1988; Rhynchorthoceras kranepuhlense sp. nov.; Rhynchorthoceras lineatum Lai, 1987; Rhynchorthoceras lunshanense Zou, 1988; Rhynchorthoceras minor Kröger et al., 2007; Rhynchorthoceras paucisinum Lai, 1987; Rhynchorthoceras rugium sp. nov.; Rhynchorthoceras 
yizanense Fang et al., 2021; Rhynchorthoceras Zaddachi Remelé, 1882; Rhynchorthoceras zhejiangense Zou, 1987.

\section{Geographic and stratigraphic occurrence}

Argentine Precordillera, Canada, Baltoscandia, Wales (?), northern Germany, Poland, the Kaliningrad Region of Russia, northern Poland, Bohemia and China; Middle to Late Ordovician.

\section{Remarks}

Rhynchorthoceras includes the stratigraphically oldest, Dapingian, lituitid species (Kröger et al. 2007; Aubrechtová \& Turek 2018; Fang et al. 2021).

Species of Rhynchorthoceras differ from the species of Sinoceras by a greater expansion angle and shorter septal necks, and from the species of Tyrioceras in shorter phragmocone chambers. Fang et al. (2021) suggested to synonymise Tyrioceras with Rhynchorthoceras, but the collection studied here is not sufficient to address this issue.

Species of Ancistroceras and Holmiceras of the family Lituitidae differ from the species of Rhynchorthoceras in the coiled juvenile conch. Also, the conchs in the species of Ancistroceras and Holmiceras usually expand more strongly and are more prominently ornamented (with annuli). However, some species of the three genera might be difficult to separate, if apical portions of the conchs are missing (Kröger et al. 2007; Aubrechtová \& Meidla 2020; Fang et al. 2021).

\section{Rhynchorthoceras angelini (Boll, 1857)}

Figs 9-12, Tables 2-3

Lituites Angelini Boll, 1857: 89.

Rhynchorthoceras Oelandicum Remelé, 1882: 134-135, pl. 5 fig. 5.

Rhynchorthoceras tenuistriatum Remelé, 1882: 137-138.

Rhynchorthoceras Angelini var. lineata Remelé, 1882: 136.

Rhynchorthoceras Angelini var. virgata Remelé, 1882: 136.

Orthoceras Angelini - Boll 1857: pl. 4 fig. 11.

Ancistroceras Angelini - Remelé 1881: 195.

Rhynchorthoceras Angelini - Remelé 1882: 135; 1890: 19. — Rüdiger 1889: 37.

Rhynchorthoceras Oelandicum - Rüdiger 1889: 40.

Rhynchorthoceras tenuistriatum - Remelé 1890: 74, pl. 5 fig. 7.

Rhynchorthoceras Angelini var. lineata - Remelé 1890: pl. 5 fig. 6, pl. 6 fig. 6.

Rhynchorthoceras Angelini var. virgata - Remelé 1890: pl. 3 fig. 5, pl. 5 figs 3-5.

Rhynchorthoceras angelini var. lineata- Neben \& Krueger 1971: pl. 21 figs 10-12.

? Rhynchorthoceras angelini - Sweet 1958: 140.

\section{Diagnosis}

Species of the genus Rhynchorthoceras with expansion angles between $8^{\circ}$ and $13^{\circ}$; whorl profile circular, in the apical part of the conch sometimes slightly compressed and flattened on the dorsum. Shell surface consists of lirae with oblique and straight course across the flank, not oblique and straight ventrally, a low dorsal projection. Transverse profile of lirae either crested or flat, commonly asymmetric. Shell wall sometimes faintly undulated. Distance of lirae regular or slightly fluctuating, gradually decreases during ontogeny. Siphuncle $0.12-0.19$ of whorl height, central or almost central in position. 


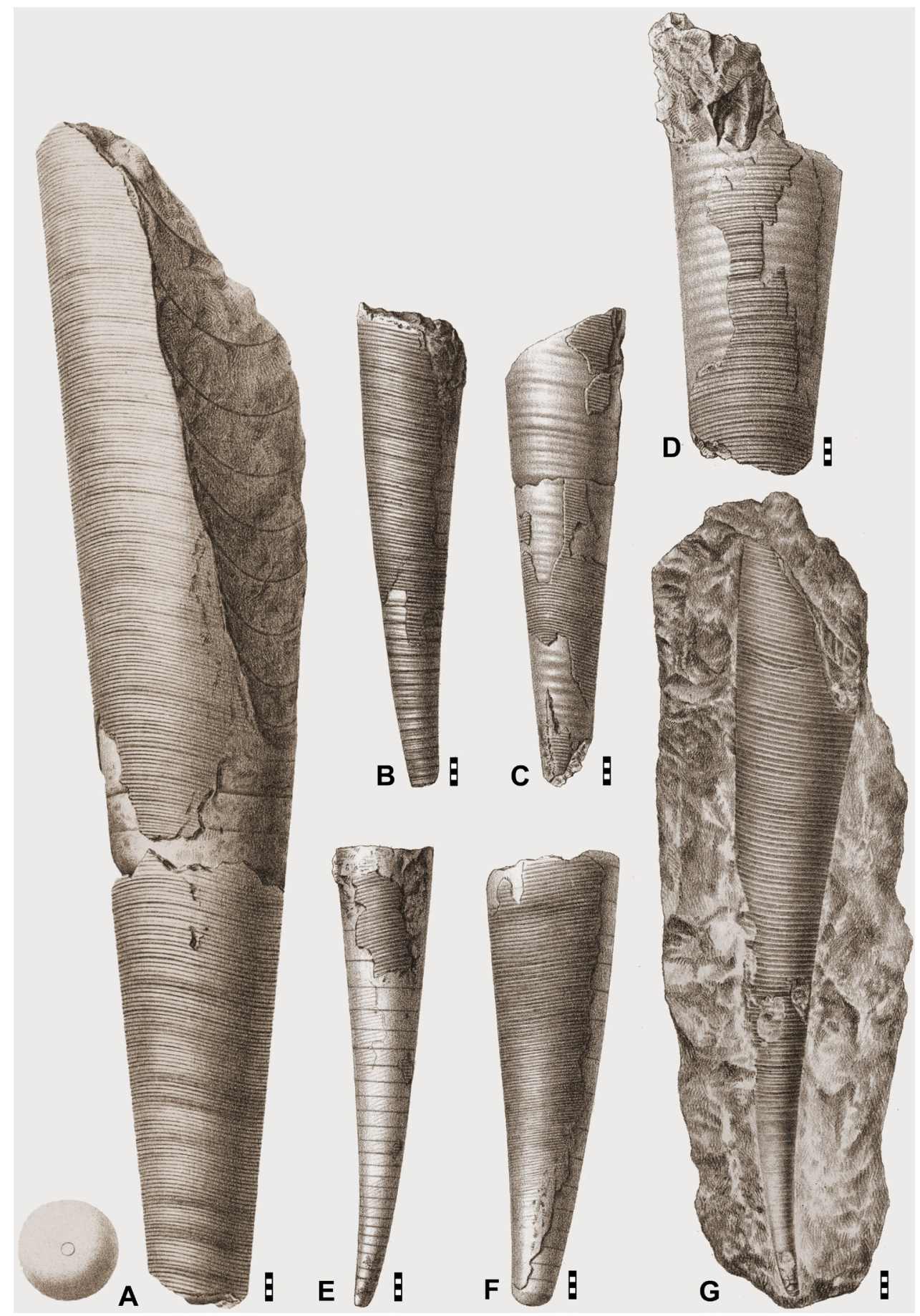

Fig. 9. Rhynchorthoceras angelini (Boll, 1857); reproductions of illustrations by Remelé (1890). A. Specimen MB.C.11724 from Heegermühle (Brandenburg), illustrated by Remelé (1890: pl. 3 fig. 5). B. Specimen MB.C. 11725.1 from Heegermühle (Brandenburg), illustrated by Remelé (1890: pl. 5 fig. 3). C. Specimen from Heegermühle (Brandenburg), illustrated by Remelé (1890: pl. 5 fig. 4). D. Specimen MB.C.11732.2 from Heegermühle (Brandenburg), illustrated by Remelé (1890: pl. 5 fig. 5). E. Specimen MB.C.11726.1 from Heegermühle (Brandenburg), illustrated by Remelé (1890: pl. 5 fig. 6). F. Specimen MB.C.11716 from Joachimsthal (Brandenburg), illustrated by Remelé (1890: pl. 5 fig. 7). G. Specimen MB.C.22577 from Heegermühle, illustrated by Remelé (1890: pl. 6 fig. 6). Scale bar units $=1 \mathrm{~mm}$. 

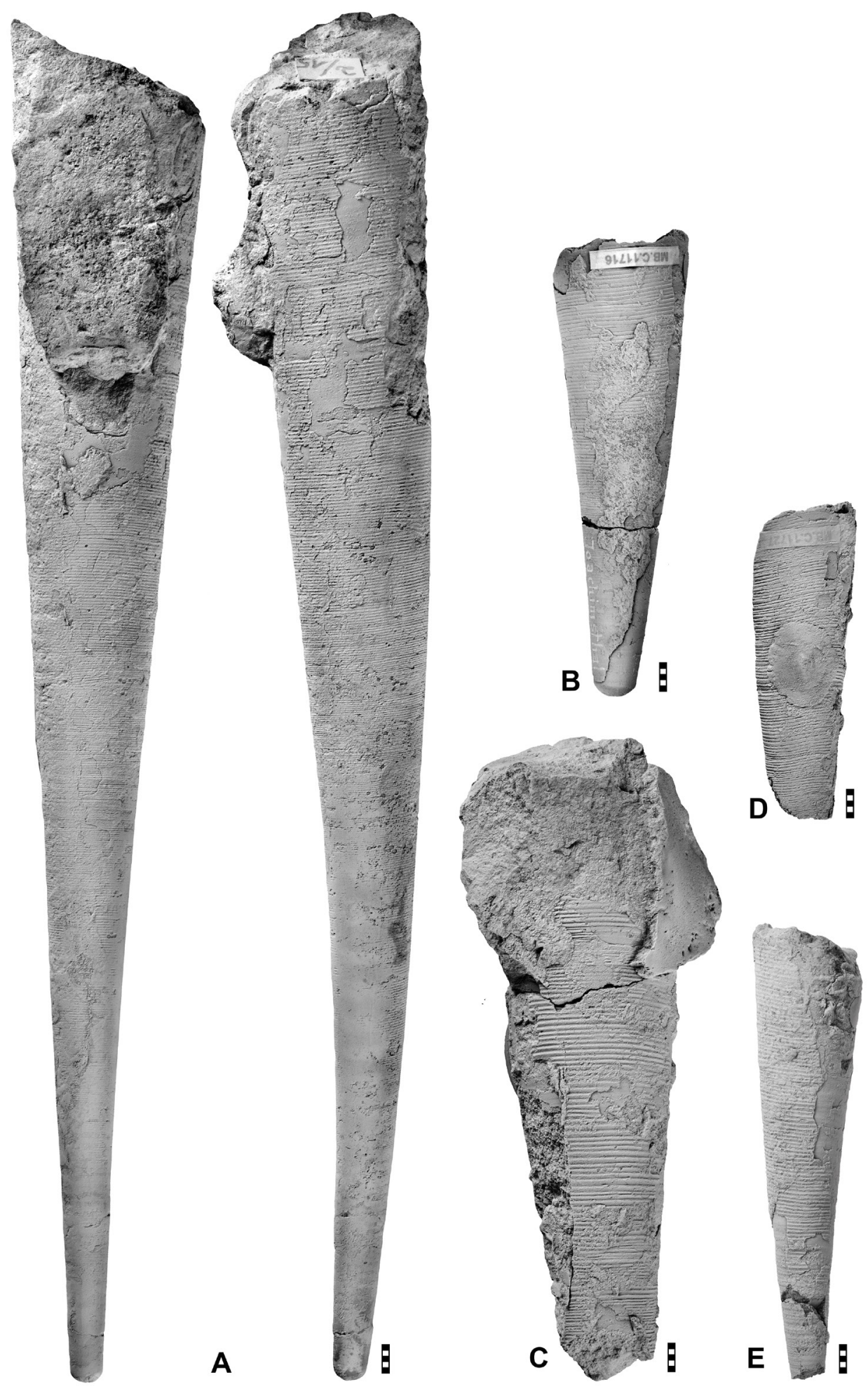

Fig. 10. Rhynchorthoceras angelini (Boll, 1857) from the Upper Red Orthoceratite Limestone. A. Specimen MB.C.29656 (Bottke Coll.) from Skärlöv (Island of Öland); ventral and lateral views. B. Specimen MB.C.11716 (Hentig 1880 Coll.) from Joachimsthal (Brandenburg); lateral view. C. Specimen MB.C.30495.1 from Heegermühle (Brandenburg); dorsal? view. D. Specimen MB.C.11727 (Schmidt Coll.) from near Berlin-Schmargendorf; lateral view. E. Specimen MB.C.11725.1 (Remelé 1879 Coll.) from Heegermühle (Brandenburg); lateral view. Scale bar units $=1 \mathrm{~mm}$. 


\section{Type material}

Not available for study; Boll (1857) did not specify a type but he had at least three specimens available, of which one was figured (Boll 1857: pl. 4 fig. 11).

\section{Material examined}

GERMANY • 1 spec.; Berlin-Schmargendorf; Ordovician, Upper Red Orthoceratite Limestone; Schmidt Coll.; MB.C.11727 - 12 specs; Brandenburg, Heegermühle; Ordovician, Upper Red Orthoceratite Limestone; Kgl. Forstakademie Eberswalde Coll.; MB.C.11724, MB.C.11726.1 to MB.C.11726.7, MB.C.11729.2 to MB.C.11729.4, MB.C.11732.2 - 8 specs; Brandenburg, Heegermühle; Ordovician, Upper Red Orthoceratite Limestone; Remelé Coll.; MB.C.11725.1, MB.C.11725.2, MB.C.11731.1 to MB.C.11731.6 • 6 specs; Brandenburg, Heegermühle; Ordovician, Upper Red Orthoceratite Limestone; MB.C.22577, MB.C.30494, MB.C.30495.1, MB.C.30495.2, MB.C.30496, MB.C.30497 • 1 spec.; Brandenburg, Hohensaaten; Ordovician, Upper Red Orthoceratite Limestone; Neben and Krueger Coll.; MB.C.30498 • 1 spec.; Brandenburg, Joachimsthal (Uckermark); Ordovician, Upper Grey Orthoceratite Limestone; Hentig 1880 Coll.; MB.C.11716 • 1 spec.; Mecklenburg-Vorpommern, Neu-Ruthenbeck (Parchim); Ordovician, Upper Grey Orthoceratite Limestone; Helms 1974 Coll.; MB.C.11717.

SWEDEN - 1 spec.; Dalarna, Skattungbyn; Ordovician, Upper Red Orthoceratite Limestone; Dames 1890 Coll.; MB.C.11720.1 • 1 spec.; Island of Öland; Ordovician; MB.C.11723 • 2 specs; Island of Öland, Skärlöv; Ordovician, Segerstad Limestone (upper part of the Upper Red Orthoceratite Limestone); Bottke Coll.; MB.C.29656, MB.C.29653.

COUNTRY UNKNOWN • 1 spec.; Ordovician; Otto Coll.; MB.C.11729.1.

\section{Description}

All available specimens are fragments of faintly curved or orthoconic phragmocones (Figs 9-10) and represent various growth stages; the smallest preserved whorl height is $3 \mathrm{~mm}$ and the largest is $40 \mathrm{~mm}$. Initial parts of the phragmocones and also mature body chambers are not preserved in any of the specimens. The expansion angles vary between $8^{\circ}$ and $13^{\circ}$ (median $=11^{\circ}, \mathrm{n}=13$; Fig. 13A). The relative chamber length is variable with a CLR between 0.25 and 0.50 (Fig. 11). The siphuncle has a central or almost central position, with diameters between 0.12 and 0.19 (median $=0.14, \mathrm{n}=13$; Fig. 13B) of the whorl height.

The shell ornament consists of lirae, which are up to $1.3 \mathrm{~mm}$ apart in the largest specimens. The distance of lirae is more or less regular, fluctuates only slightly and gradually decreases during ontogeny (e.g., MB.C. 11724, relative distance from ca 0.04 at wh $19 \mathrm{~mm}$ to ca 0.02 at wh $39 \mathrm{~mm}$, Fig. 12B-C). The lirae extend straight across the venter; they are oblique and straight on the flanks and form a low projection on the dorsum (Fig. 12A, MB.C.11725.1). Their profile is crested and symmetric (MB.C.30495.1, MB.C.11724, MB.C.29656), crested and asymmetric (MB.C.11725.1) or flat and weakly asymmetric or symmetric (MB.C.11727, MB.C.22577).

\section{Remarks}

Rhynchorthoceras angelini differs from $R$. tenuistriatum (from Middle Ordovician erratics of northern Germany) in the slightly lower expansion angle $\left(8-12^{\circ}\right.$ vs $\left.13^{\circ}\right)$ and from $R$. oelandicum (from Middle Ordovician strata of Öland and erratics of northern Germany) in the central (vs slightly eccentric) position of the siphuncle in large growth stages. In all other characters, including the shell ornament, $R$. angelini is indistinguishable from $R$. tenuistriatum and $R$. oelandicum. Consequently, both $R$. tenuistriatum and $R$. oelandicum are synonymised with $R$. angelini herein. 
Table 2 (continued on next page). Conch measurements (in $\mathrm{mm}$ ), and expansion rates of specimens of Rhynchorthoceras Remelé, 1882.

\begin{tabular}{|c|c|c|c|c|c|c|c|c|}
\hline $\operatorname{tax} o n$ & catalogue nr & $\max . w h$ & max. ww & min. wh & $\min . w w$ & $\begin{array}{c}\min \\
\text { WWI }\end{array}$ & $\begin{array}{l}\text { fragm. } \\
\text { length }\end{array}$ & $\mathbf{E A}\left({ }^{\circ}\right)$ \\
\hline R. rugium & MB.C. 11728 & 22.2 & 22.2 & 3.6 & 3.6 & 1.00 & 103.2 & 10.3 \\
\hline R. kranepuhlense & MB.C. 11730 & 24.0 & - & 3.6 & 3.6 & 1.00 & 111.0 & 10.5 \\
\hline R. kranepuhlense & MB.C.30491 & 23.3 & - & 2.7 & 2.6 & 0.96 & 126.6 & 9.3 \\
\hline R. kranepuhlense & MB.C.30492 & 23.5 & - & 9.0 & - & - & 77.4 & 10.7 \\
\hline R. kranepuhlense & MB.C.30493 & 21.0 & 21.0 & 10.2 & 10.2 & 1.00 & 74.4 & 8.3 \\
\hline R. angelini & MB.C. $11723 b$ & - & 30.0 & - & 13.0 & - & 82.2 & 11.8 \\
\hline R. angelini & MB.C. 11729.4 & 17.8 & - & 13.4 & - & - & 25.1 & 10.0 \\
\hline R. angelini & MB.C.11727 & - & 20.6 & - & 11.8 & - & 48.8 & 10.3 \\
\hline R. angelini & MB.C.11726.1 & 17.0 & 16.5 & 4.0 & 4.0 & 1.00 & 67.5 & 11.0 \\
\hline R. angelini & MB.C.29656 & - & 33.0 & 5.7 & 5.6 & 0.98 & 209.0 & 7.5 \\
\hline R. angelini & MB.C.30495.1 & 29.3 & 29.3 & 18.0 & 18.0 & 1.00 & 52.0 & 12.4 \\
\hline R. angelini & MB.C.30495.2 & 38.0 & - & 23.0 & - & - & - & - \\
\hline R. angelini & MB.C.30497 & - & 26.0 & 11.4 & 11.4 & 1.00 & 75.8 & 11.0 \\
\hline R. angelini & MB.C.11724 & 39.0 & & 18.5 & 18.3 & 0.99 & 143.0 & 8.2 \\
\hline R. angelini & MB.C.11725.1 & 19.0 & 19.0 & 6.3 & 6.2 & 0.98 & 63.6 & 11.4 \\
\hline R. angelini & MB.C. 11732.2 & 29.7 & - & 22.7 & - & - & 36.7 & 10.9 \\
\hline R. angelini & MB.C. 11720.1 & 39.5 & - & 11.4 & 11.0 & 0.96 & - & - \\
\hline R. angelini & MB.C.30498 & 29.0 & - & 15.4 & 15.4 & 1.00 & 74.0 & 10.5 \\
\hline R. angelini & MB.C.29653 & 35.3 & - & 3.3 & 3.0 & 0.91 & 166.1 & 11.0 \\
\hline R. angelini & MB.C.11716 & 23.0 & 22.5 & 7.6 & 7.5 & 0.99 & 69.7 & 12.6 \\
\hline R. beyrichii & MB.C.11718a,b & 26.0 & - & 15.5 & - & - & 34.5 & 17.3 \\
\hline R. conicum & MB.C.30499 & 21.7 & 21.0 & 5.5 & 5.5 & 1.00 & 77.1 & 12.0 \\
\hline R. conicum & MB.C.11723a & 21.0 & 19.3 & 10.5 & 10.3 & 0.98 & 60.0 & 10.0 \\
\hline R. conicum & MB.C.30507 & 21.0 & 20.1 & 7.2 & 7.1 & 0.99 & 78.1 & 10.1 \\
\hline R. conicum & MB.C.30508 & 16.5 & 16.5 & 8.3 & 8.0 & 0.96 & 39.3 & 11.9 \\
\hline R. conicum & MB.C.11702 & 46.0 & - & 6.0 & - & - & 178.3 & 12.8 \\
\hline R. conicum & MB.C.11703 & 38.0 & - & 8.0 & - & - & 174.9 & 9.8 \\
\hline R. conicum & MB.C.11719.1 & 36.0 & - & 8.3 & 8.2 & 0.99 & 150.7 & 10.5 \\
\hline R. conicum & MB.C.11719.2 & 15.3 & 15.1 & 8.0 & 7.7 & 0.96 & 44.4 & 9.4 \\
\hline R. conicum & MB.C. 11721 & 19.0 & - & 8.6 & 8.8 & 1.02 & 66.1 & 9.0 \\
\hline R. conicum & MB.C.30505 & 27.0 & - & 7.6 & 7.4 & 0.97 & 116.7 & 9.5 \\
\hline R. conicum & MB.C.30501 & 18.0 & - & 2.8 & - & - & 84.3 & 10.3 \\
\hline R. conicum & MB.C.30506 & 17.3 & 17.3 & 3.0 & - & - & 78.6 & 10.4 \\
\hline R. conicum & MB.C.30502 & 40.0 & - & 4.4 & - & - & 172.2 & 11.8 \\
\hline
\end{tabular}


Table 2 (continued). Conch measurements (in $\mathrm{mm}$ ), and expansion rates of specimens of Rhynchorthoceras Remelé, 1882.

\begin{tabular}{lcccccccc}
\hline taxon & catalogue nr & max. wh & max. ww & min. wh & min. ww & $\begin{array}{c}\text { min } \\
\text { WWI }\end{array}$ & $\begin{array}{c}\text { fragm. } \\
\text { length }\end{array}$ & EA ( $)$ \\
\hline$R$. conicum & MB.C.30503 & 41.5 & - & 6.2 & - & - & 176.8 & 11.4 \\
$R$. conicum & MB.C.11715 & 20.6 & - & 5.0 & - & - & 79.5 & 11.2 \\
$R$. sp. & MB.C.11712 & - & 46.0 & 30.0 & 30.0 & 1.00 & 76.1 & 12.0 \\
$R$. sp. & MB.C.11713 & 28.0 & - & 12.0 & - & 1.00 & 91.4 & 10.0 \\
$R$. sp. & MB.C.29652 & 27.0 & - & 5.0 & - & - & 101.2 & 12.4 \\
$R$. sp. & MB.C.30511 & 39.0 & - & 9.0 & 8.7 & 0.97 & 124.9 & 13.7 \\
$R$. sp. & MB.C.30512 & 40.0 & - & 8.0 & - & - & 152.2 & 12.0 \\
$R$. sp. & MB.C.30514 & 41.0 & - & 5.2 & 5.2 & 1.00 & 194.8 & 10.5 \\
$R$. sp. & MB.C.30513 & 38.0 & - & 10.0 & 10.0 & 1.00 & 120.1 & 13.3 \\
$R$. sp. & MB.C.11711 & 46.0 & - & 11.0 & 11.0 & 1.00 & 163.7 & 12.2 \\
\hline
\end{tabular}

The intraspecific variation of $R$. angelini also concerns the shell ornament. Remelé $(1882,1890)$ recognised two varieties within the species: $R$. angelini var. virgata with more prominent lirae with acute, symmetric or asymmetric crests, while the lirae in $R$. angelini var. lineata are flat and only very slightly asymmetric. Remelé considered them as varieties of a single species because of common transitions between the two types of ornament. Furthermore, the specimens do not differ in any other morphological characters. Based on the study of original specimens of Remelé $(1882,1890)$ and subsequently collected material, the varieties are not distinguished here and only the name $R$. angelini is used.
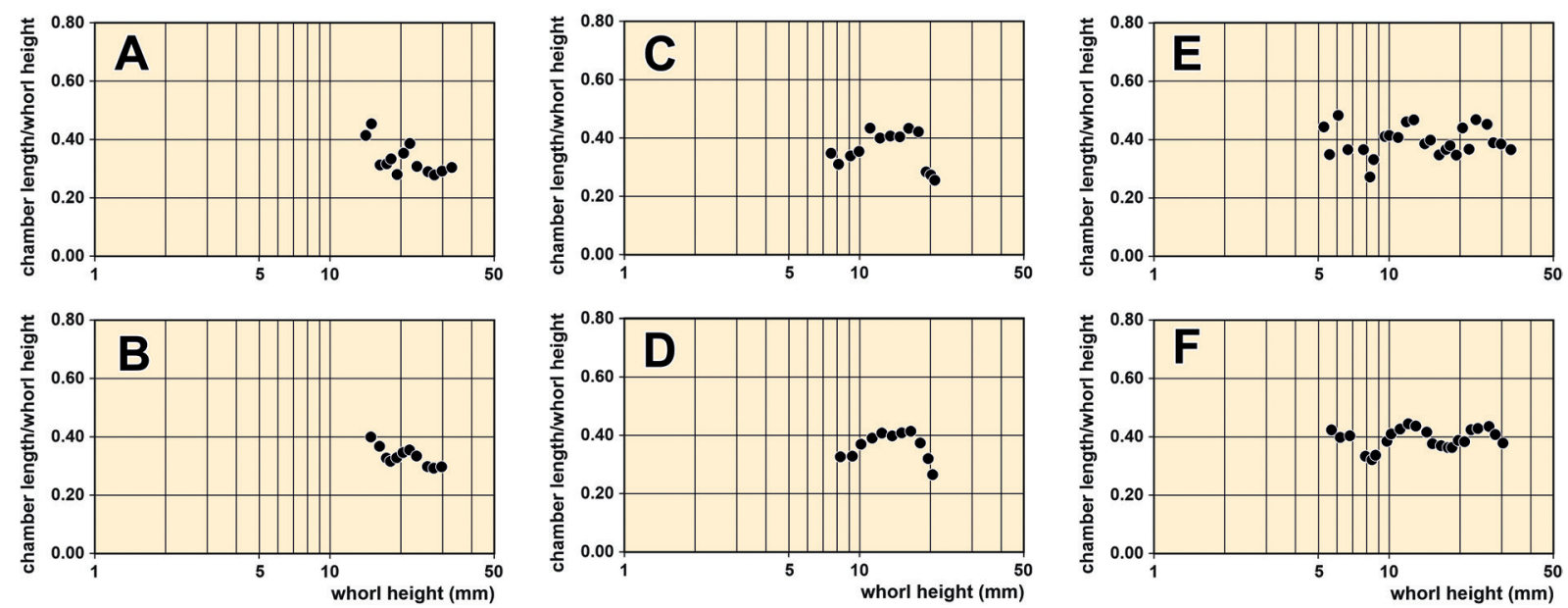

Fig. 11. Septum distances in Rhynchorthoceras angelini (Boll, 1857) from the Upper Red Orthoceratite Limestone. Upper row $=$ empirical data points; lower row $=$ three data points averaged. A-B. Specimen MB.C.11725.1 (Remelé 1879 Coll.) from Heegermühle (Brandenburg). C-D. Specimen MB.C.11716 (Hentig 1880 Coll.) from Joachimsthal (Brandenburg). E-F. Specimen MB.C.29653 (Bottke Coll.) from Gärdslösa (Island of Öland, Sweden). 
Rhynchorthoceras angelini is, together with $R$. conicum, by far the most abundant representative of Rhynchorthoceras in the Aserian and Lasnamägian (Middle Ordovician) strata of Baltoscandia and erratics in Germany and Poland. Most of the reported occurrences come from the Upper Red Orthoceratite Limestone, where $R$. angelini co-occurs with Trilacinoceras discors (Holm, 1891) and possibly other lituitids (e.g., Jaanusson 1960). The species is palaeogeographically widespread and stratigraphically long-ranging compared to other species of the genus; it probably occurs already in the latest Dapingian (early Middle Ordovician) rocks of central Bohemia (Marek 1999; Manda 2008; Aubrechtová \& Turek 2018).

\section{Geographic and stratigraphic occurrence}

Norway (?), Sweden (in situ) and northern Germany (in erratics within Pleistocene gravels), central Bohemia (?); middle Volkhov (?), Kunda to Lasnamägi regional stages (latest Dapingian (?) to late Darriwilian, Middle Ordovician).

$\uparrow$

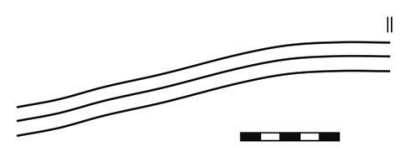

A

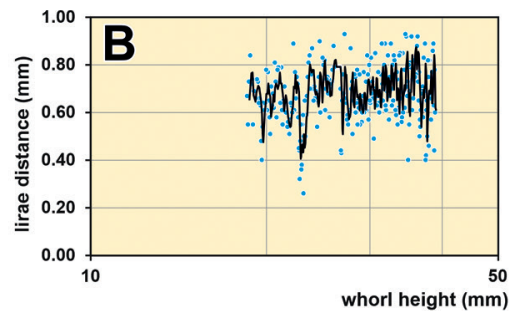

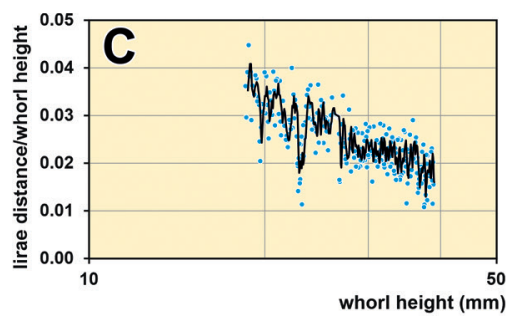

Fig. 12. Rhynchorthoceras angelini (Boll, 1857) from the Upper Red Orthoceratite Limestone. A. Lirae of specimen MB.C.11725.1 (Remelé 1879 Coll.) from Heegermühle (Brandenburg), at wh $=14 \mathrm{~mm}$. B-C. Ontogenetic development of lirae distance (in $\mathrm{mm}$ ) and lirae distance/whorl height of specimen MB.C.11724 (Kgl. Forstakademie Eberswalde Coll.) from Heegermühle (Brandenburg). Blue dots = individual measurements, black lines $=$ three data point averaged values. Scale bar units $=1 \mathrm{~mm}$.
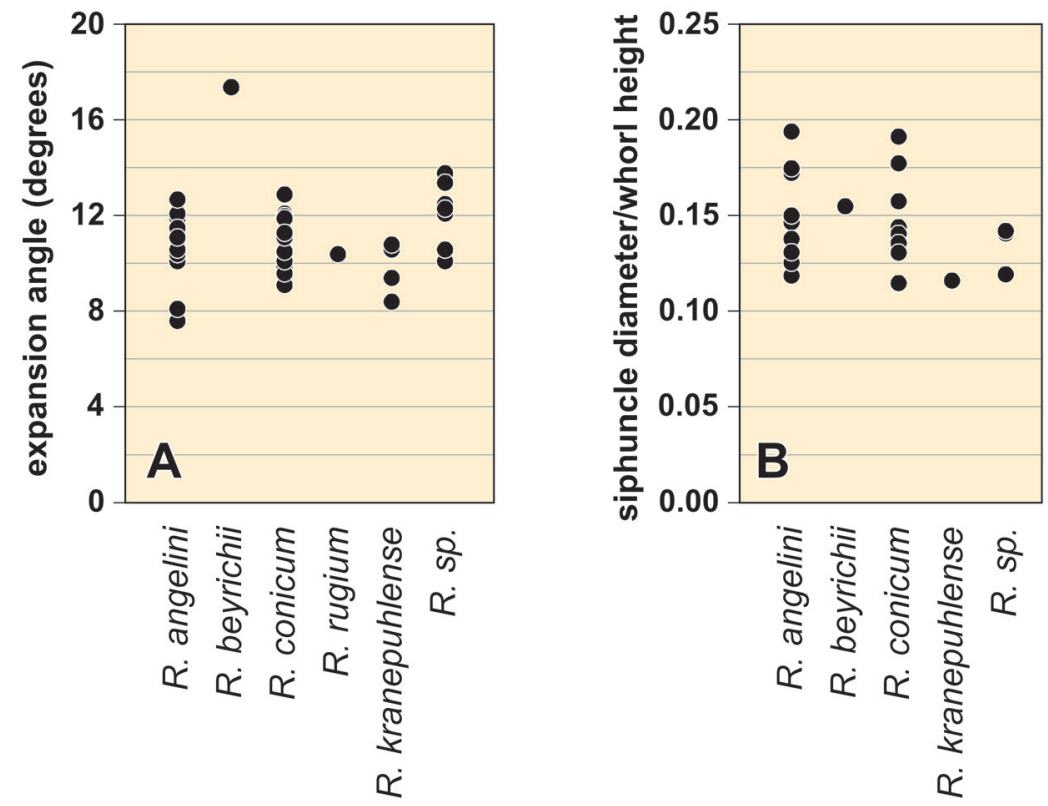

Fig. 13. Conch expansion rates (A) and siphuncle diameter rates (B) in species of Rhynchorthoceras Remelé, 1882. 
Rhynchorthoceras conicum (Hisinger, 1837)

Fig. 14A-C, Tables $2-3$

Orthoceratites conicus Hisinger, 1837: 29, pl. 9 fig. 5.

Orthoceras conicum - Boll 1857: 72, pl. 4 fig. 12. - Angelin 1880: 5, pl. 9 figs 2-3. — Rüdiger 1889: 18, pl. 1 fig. 4.

? Orthoceras conicum - Angelin 1880: pl. 9 fig. 1

Conorthoceras conicus - Troedsson 1931: 24

Rhynchorthoceras angelini - Hardt 1953: 44, text-fig. 9.

Rhynchorthoceras conicum - Dzik 1984: 133, pl. 38 figs 3-4, text-fig. 50d-e. — Kröger 2004b: 65. Kröger et al. 2007: 1280.

Sinoceratidae, gen et sp. nov. cf. "Conorthoceras" conicum - King 1999: fig. 6a-b.

non Orthoceras conicum - Woodward 1856: 379, pl. 6 fig. 2.

non Nevadaceras conicum - Flower 1968: 43.

\section{Diagnosis}

Species of the genus Rhynchorthoceras with expansion angle of $9-13^{\circ}$; whorl profile circular. Shell surface smooth or decorated with extremely fine transverse and/or longitudinal lines. Siphuncle diameter $0.11-0.19$ of whorl height, central or nearly central in position.

\section{Type material}

Not available for study; Hisinger (1837: pl. 9 fig. 5) did not specify a type but he figured one specimen that was re-figured by Boll (1857: pl. 4 fig. 12).

\section{Material examined}

GERMANY • 1 spec.; Brandenburg, Gellmersdorf (Angermünde); Ordovician; Schröter 1979 Coll.; MB.C.11715 - 2 specs; Brandenburg, Heegermühle; Ordovician, Upper Red Orthoceratite Limestone; MB.C.30499, MB.C.30500 • 3 specs; Brandenburg, Niederfinow; Ordovician, Upper Red Orthoceratite Limestone; Neben and Krueger Coll.; MB.C.30501 to MB.C.30503 • 1 spec.; Brandenburg, Niederfinow; Ordovician, Upper Red Orthoceratite Limestone; Neben and Krueger Coll.; MB.C.30504 • 1 spec.; Brandenburg, Niederlehme; Ordovician; Siegert 1914 Coll.; MB.C.11703 - 2 specs; Brandenburg, Oderberg; Ordovician, Upper Red Orthoceratite Limestone; Neben and Krueger Coll.; MB.C.30505, MB.C.30506 - 1 spec.; Brandenburg, Oderberg; Ordovician, Upper Red Orthoceratite Limestone; Remelé Coll.; MB.C.30507.

POLAND • 1 spec.; West Pomerania, Dewitz Castle, Dobra (former Dewitzburg bei Daber); Ordovician, Upper Red Orthoceratite Limestone; MB.C.30508 - 1 spec.; West Pomerania, Skowarcz (former Schönwarling), Gdańsk County; Ordovician, Upper Red Orthoceratite Limestone; Hoyers 1912 Coll.; MB.C.30509.

SWEDEN • 1 spec.; Dalarna; Ordovician; Coll.; MB.C.11721 • 2 specs; Island of Öland; Ordovician; Coll.; MB.C.11702, MB.C.11723 - 1 spec.; Island of Öland, Triberga; Ordovician, Upper Red Orthoceratite Limestone; Dames 1881 Coll.; MB.C.11722.

COUNTRY UNKNOWN • 2 specs; Ordovician; Otto Coll.; MB.C.11719.1, MB.C.11719.2. 


\section{Description}

All specimens are fragments of faintly curved or orthoconic phragmocones (Fig. 14A-C) and represent various growth stages of the conch, with the smallest preserved whorl height of $3 \mathrm{~mm}$ and the largest of $40 \mathrm{~mm}$. None of the specimens has initial parts of the phragmocone or a mature body chamber preserved. The expansion angles vary between $9^{\circ}$ and $13^{\circ}$ (median $=11^{\circ}, \mathrm{n}=15$; Fig. 13A). The relative chamber length is variable, the CLR is between 0.18 and 0.32 . The siphuncle is central or almost central in position and its diameter is between 0.11 and 0.19 (median $=0.14, n=9$; Fig. 13B) of the whorl height. The shell surface is nearly smooth; only some specimens (MB.C. 11723a, MB.C.11721, MB.C.30501) possess delicate longitudinal and/or transverse lines or impressions.

\section{Remarks}

Troedsson (1931) stated that Orthoceratites conicus is the type species of a new genus Conorthoceras. However, Troedsson did not formally describe the genus, nor did he provide any diagnosis, descriptions or figures. The validity of the name Conorthoceras was disputed by Jaanusson \& Mutvei (1953) and Teichert (1964), but Sweet (1958) considered the name as valid. The systematic position of O. conicus remained unclear, until Dzik (1984) assigned the species to Rhynchorthoceras, thereby acknowledging its lituitid affinities. King $(1990,1999)$ agreed that $O$. conicus represented a lituitid but suggested that the smooth shell surface would justify a separate genus. Later authors (e.g., Kröger 2004b; Kröger et al. 2007) retained the species in Rhynchorthoceras, which is also the approach followed herein.

Rhynchorthoceras conicum must not be confused with Nevadaceras conicum Flower, 1968. The latter is known from a single, fragmentary specimen, which has oblique sutures, compressed whorl profile and a wider siphuncle ( 0.25 of whorl height) located between the centre and venter. Thus, $N$. conicum can neither be synonymised with $R$. conicum, nor assigned to the order Lituitida.

Rhynchorthoceras conicum is almost identical, in conch proportions and internal conch morphology, to $R$. angelini, $R$. kranepuhlense sp. nov. and $R$. rugium sp. nov. (all described herein), but it can be readily distinguished by the smooth surface of its shell.

\section{Geographic and stratigraphic occurrence}

Sweden (in situ) and northern Germany and Poland (in erratics within Pleistocene gravels); Aseri to Lasnamägi regional stages (middle to late Darriwilian, Middle Ordovician).

Rhynchorthoceras beyrichii Remelé, 1882

Fig. 14D, Tables 2-3

Rhynchorthoceras Beyrichii Remelé, 1882: 128, pl. 5 fig. 3a-b.

Orthoceratites - Breyn 1732: 33, pl. 4 figs 1-3.

Ancistroceras Breynii-Remelé 1881: 194.

Rhynchorthoceras beyrichi - Foerste 1930: 277, pl. 42 fig. 2a-c. — Balashov 1962: pl. 7 fig. 3.

\section{Diagnosis}

Species of the genus Rhynchorthoceras with an expansion angle of $15-17^{\circ}$. Shell surface with pronounced lirae, straight in the apical part but faintly sinuous later in ontogeny. Distance of lirae increasing up to $1.5 \mathrm{~mm}$ during ontogeny; distance and thickness of lirae might be irregular. Siphuncle eccentric in position (after Remelé 1882). 
Table 3. Siphuncular diameter ratio (SDR) and siphuncular distance ratio (SPR) at their corresponding whorl height in specimens of Rhynchorthoceras Remelé, 1882.

\begin{tabular}{llcccc}
\hline taxon & catalogue $\mathbf{n r}$ & wh & SDR & wh & SPR \\
\hline$R$. kranepuhlense & MB.C. 11730 & 20.0 & 0.12 & - & - \\
$R$. angelini & MB.C. 11729.4 & 17.8 & 0.13 & - & - \\
$R$. angelini & MB.C. 11727 & 20.6 & 0.15 & - & - \\
$R$. angelini & MB.C. 11726.1 & 17.0 & 0.12 & 17.0 & 0.47 \\
$R$. angelini & MB.C. 29656 & 5.7 & 0.19 & - & - \\
$R$. angelini & MB.C. 30495.1 & 28.0 & 0.17 & - & - \\
$R$. angelini & MB.C. 11724 & 18.5 & 0.12 & 18.5 & 0.49 \\
$R$. angelini & MB.C. 11725.1 & 19.0 & 0.14 & 19.0 & 0.47 \\
$R$. angelini & MB.C. 11720.1 & 11.4 & 0.15 & - & - \\
$R$. angelini & MB.C. 30498 & 15.4 & 0.13 & - & 0.50 \\
$R$. angelini & MB.C. 11716 & 23.0 & 0.17 & 23.0 & 0.48 \\
$R$. beyrichii & MB.C. $11718 \mathrm{a}, \mathrm{b}$ & 26.0 & 0.15 & 26.0 & 0.42 \\
$R$. conicum & MB.C. 30499 & 21.0 & 0.14 & - & - \\
$R$. conicum & MB.C. $11723 \mathrm{a}$ & 10.5 & 0.19 & 10.5 & 0.44 \\
$R$. conicum & MB.C. 30507 & 7.2 & 0.14 & 7.2 & 0.50 \\
$R$. conicum & MB.C. 30508 & 16.5 & 0.14 & 16.5 & 0.50 \\
$R$. conicum & MB.C. 11702 & 26.0 & 0.13 & - & - \\
$R$. conicum & MB.C. 11719.1 & 8.3 & 0.16 & - & - \\
$R$. conicum & MB.C. 11719.2 & 15.3 & 0.18 & - & - \\
$R$. conicum & MB.C. 30505 & 27.0 & 0.13 & - & - \\
$R$. conicum & MB.C. 30502 & 4.4 & 0.11 & - & - \\
$R$. sp. & MB.C. 11713 & 26.5 & 0.14 & 26.5 & 0.49 \\
$R$. sp. & MB.C. 30511 & 39.0 & 0.14 & 39.0 & 0.46 \\
$R$. sp. & MB.C. 30514 & - & - & - & 0.50 \\
$R$. sp. & MB.C. 11711 & 11.0 & 0.12 & 11.0 & 0.48 \\
\hline & & & & &
\end{tabular}

\section{Type material}

Not available for study; Remelé (1882: pl. 5 fig. 3a-b) did not specify a type, but he mentioned and illustrated only one specimen from Szczecin (formerly Stettin; West Pomerania, Poland), found in Upper Grey Orthoceratite Limestone erratics in Pleistocene gravel (late Darriwilian, Middle Ordovician).

\section{Material examined}

POLAND • 1 spec.; Osselsk; Ordovician; Henke 1901 Coll.; MB.C.11718.

\section{Description}

Specimen MB.C.11718 (Fig. 14D) is a $50 \mathrm{~mm}$ long fragment of an orthoconic phragmocone; it is sectioned along the median plane (a thin section was also produced by a previous researcher). The conch expands with an expansion angle of $17^{\circ}$. The ornament consists of flat, asymmetric lirae (the steeper side facing the aperture), which form a shallow lateral sinus and a low dorsal projection. The shell wall 

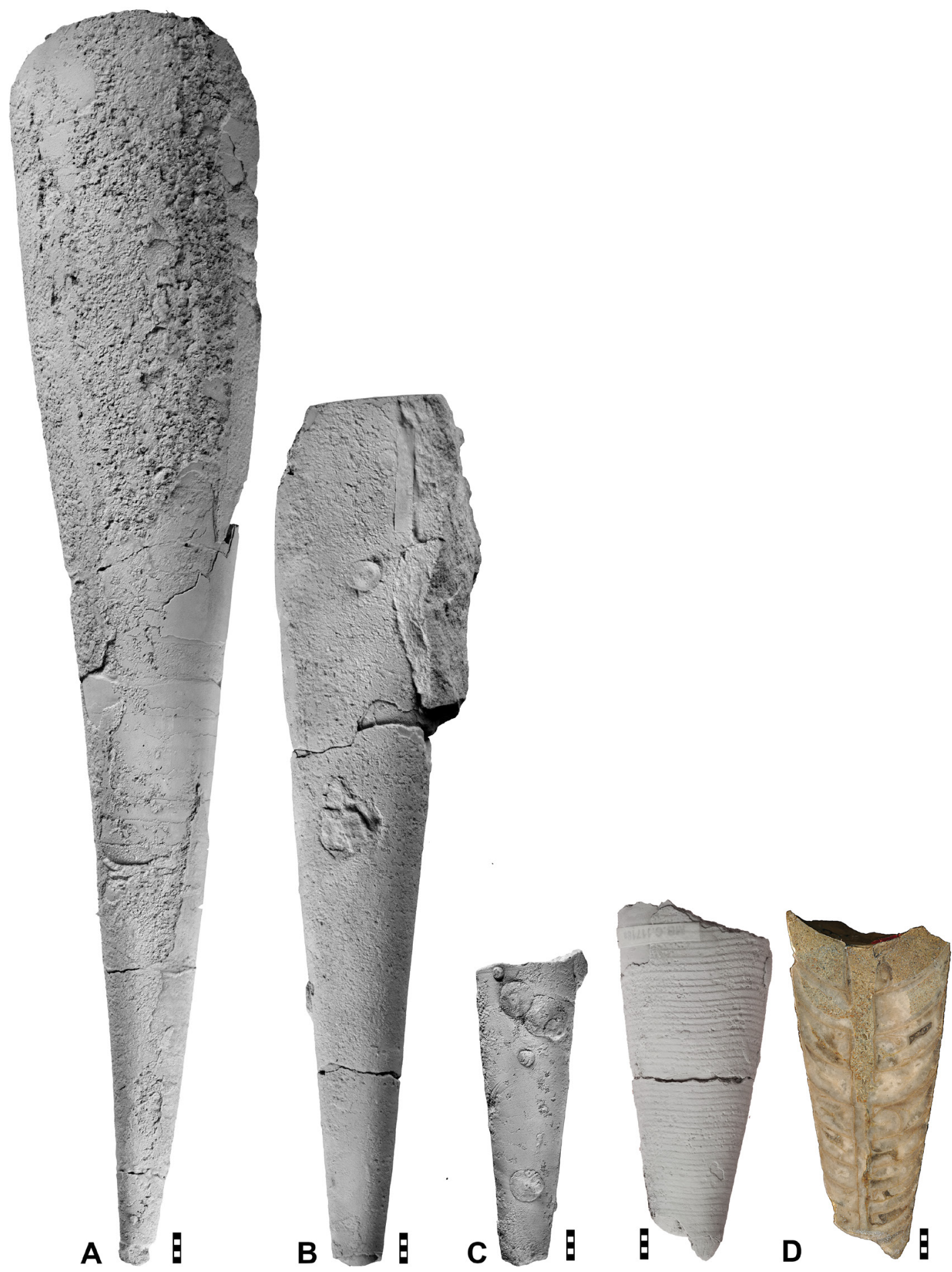

Fig. 14. Species of Rhynchorthoceras Remelé, 1882 from the Upper Red Orthoceratite Limestone. A. Rhynchorthoceras conicum (Hisinger, 1837), specimen MB.C.30503 (Neben \& Krueger Coll.) from Niederfinow (Brandenburg); lateral view. B. Rhynchorthoceras conicum (Hisinger, 1837), specimen MB.C.11719.1 (Otto Coll.) from an unknown locality; dorsal? view. C. Rhynchorthoceras conicum (Hisinger, 1837), specimen MB.C.30508 from Dewitz Castle, Dobra (former Dewitzburg bei Daber; West Pomerania, Poland); lateral? view. D. Rhynchorthoceras beyrichii Remelé, 1882, specimen MB.C.11718 (Henke 1901 Coll.) from Osselsk (Poland); previously figured by Foerste (1930: pl. 42 fig. 2); lateral view and polished median section. Scale bar units $=1 \mathrm{~mm}$. 
is not preserved on the ventral side. During ontogeny, the siphuncle shifts slightly in position (from $0.40-0.45)$; it has a diameter of 0.15 of the whorl height. The connecting rings are slightly expanded in their first half. The chamber length is stable (CLR $=0.25-0.27)$.

\section{Remarks}

Rhynchorthoceras beyrichii is distinguished from the other species of the genus by the moderately high expansion angle $\left(15^{\circ}-17^{\circ}\right)$ and an ornament with sinuous lirae. The lirae are much less sinuous and narrower than in the otherwise similar $R$. breynii (from Middle Ordovician erratics of northern Germany) and R. zaddachi (Remelé, 1882) (from Darriwilian erratics of the Kaliningrad Region, Russia).

Rhynchorthoceras beyrichii is a rare species that is unequivocally known only from two specimens figured by Remelé (1882) and Foerste (1930); the latter specimen was available for study herein. Dzik (1984) figured a specimen of Rhynchorthoceras from Volkhovian (early Middle Ordovician) strata of Poland that he assigned to $R$. aff. beyrichi.

\section{Geographic and stratigraphic occurrence}

Poland (in erratics within Pleistocene gravels); Upper Grey Orthoceratite Limestone, late Lasnamägi Regional Stage (late Darriwilian, Middle Ordovician).

Rhynchorthoceras rugium $\mathrm{sp}$. nov. urn:1sid:zoobank.org:act:3285F969-0E64-45B9-87BA-52BECCB14B9E

Fig. 15A, Table 2

\section{Diagnosis}

Species of the genus Rhynchorthoceras with an expansion angle of $10^{\circ}$; whorl profile circular. Shell surface with transverse striae, which are arranged conspicuously far apart from each other (up to $4 \mathrm{~mm}$ at wh $=22 \mathrm{~mm}$ ), distance increasing more or less regularly during ontogeny. Striae oblique but straight laterally, directly transverse and straight ventrally, with a low projection dorsally.

\section{Etymology}

From Rugia, the Latin name of the Island of Rügen, from which the holotype originates.

\section{Type material}

\section{Holotype}

GERMANY • Mecklenburg-Vorpommern, Mönchgut Penninsula (Island of Rügen); Ordovician, Upper Red Orthoceratite Limestone (Kunda Regional Stage, middle Darriwilian); Hoffmann 1972 Coll.; MB.C.11728 (illustrated in Fig. 15A).

\section{Description}

Holotype MB.C.11728 (Fig. 15A) is an orthoconic but apically weakly curved phragmocone of $125 \mathrm{~mm}$ length. At its maximum whorl height of $22 \mathrm{~mm}$, the conch has a circular cross section; the expansion angle is $10^{\circ}$. The shell ornament is preserved in more than half of the specimen and consists of transverse striae. The distances of these increase gradually along the conch and stand conspicuously far apart (up to $4 \mathrm{~mm}$ ). Only at a whorl height of $18 \mathrm{~mm}$, the striae stand closer together. They extend in oblique direction with straight course across the flanks and are straight on the venter; on the dorsum they form a low projection. 


\section{Remarks}

Rüdiger (1889) was the first to recognise striated forms of Rhynchorthoceras and considered them as representing a separate species. Patrunky (1926) named these forms $R$. ruedigeri but did not provide any further description or figures. The name Rhynchorthoceras ruedigeri is thus a nomen nudum and two striated species of Rhynchorthoceras are newly defined here (see also the text below).

Rhynchorthoceras rugium sp. nov. might be confused with $R$. angelini (described above), if lirae in the latter are very flat or poorly preserved. However, the ornament elements are apparently more widely spaced in $R$. rugium sp. nov. The other striated species, $R$. kranepuhlense sp. nov. (described below), differs from $R$. rugium sp. nov. in its finer, more irregularly spaced striae; furthermore, the conch is locally slightly constricted in $R$. kranepuhlense sp. nov.
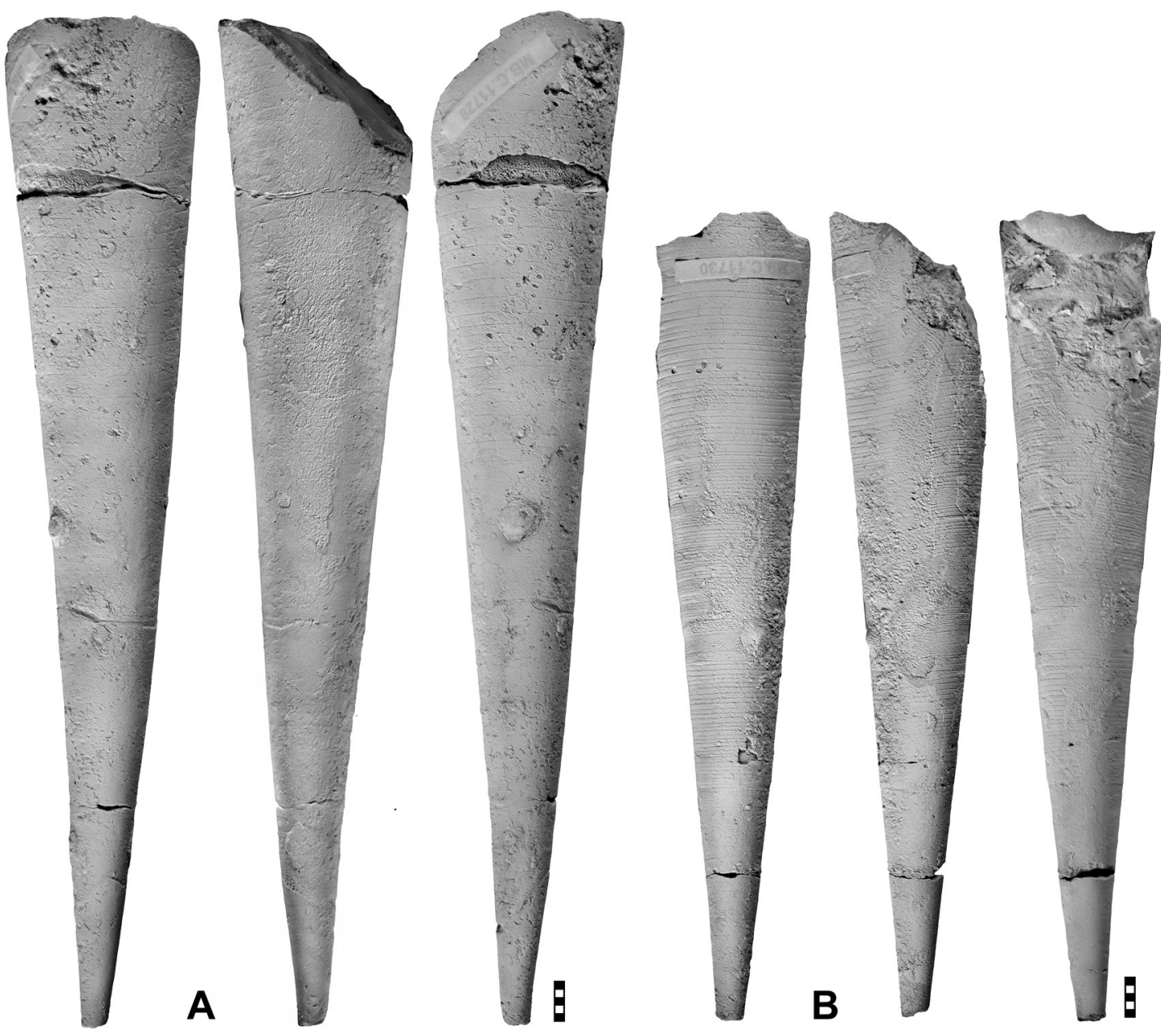

Fig. 15. Species of Rhynchorthoceras from the Upper Red Orthoceratite Limestone. A. Rhynchorthoceras rugium sp. nov., holotype MB.C.11728 (Hoffmann \& Gager 1972 Coll.) from Mönchgut (Island of Rügen); lateral, dorsal and ventral views. B. Rhynchorthoceras kranepuhlense sp. nov., holotype MB.C.11730 (Kummerow Coll.) from Kranepuhl (Brandenburg); ventral, lateral and dorsal views. Scale bar units $=1 \mathrm{~mm}$. 
Rhynchorthoceras kranepuhlense sp. nov. urn:1sid:zoobank.org:act:C6275788-FF3A-4730-9E8B-237DC086E929

Figs 15B, 16, Tables 2-3

\section{Diagnosis}

Species of the genus Rhynchorthoceras with expansion angles between $8^{\circ}$ and $11^{\circ}$; whorl profile circular. Shell surface with transverse striae, up to $1 \mathrm{~mm}$ apart (at wh $=21 \mathrm{~mm}$ ) and spaced irregularly. Conch slightly constricted, where the striae are finest. The striae extend oblique but straight laterally and directly transverse and straight ventrally, with a low projection dorsally. Siphuncle ca 0.12 in diameter, central or almost central in position.

\section{Etymology}

From the type locality Kranepuhl.

\section{Type material}

\section{Holotype}

GERMANY - Brandenburg, Kranepuhl; Ordovician, Upper Red Orthoceratite Limestone (Aseri Regional Stage, middle Darriwilian); Kummerow Coll.; MB.C.11730 (illustrated in Fig. 15B).
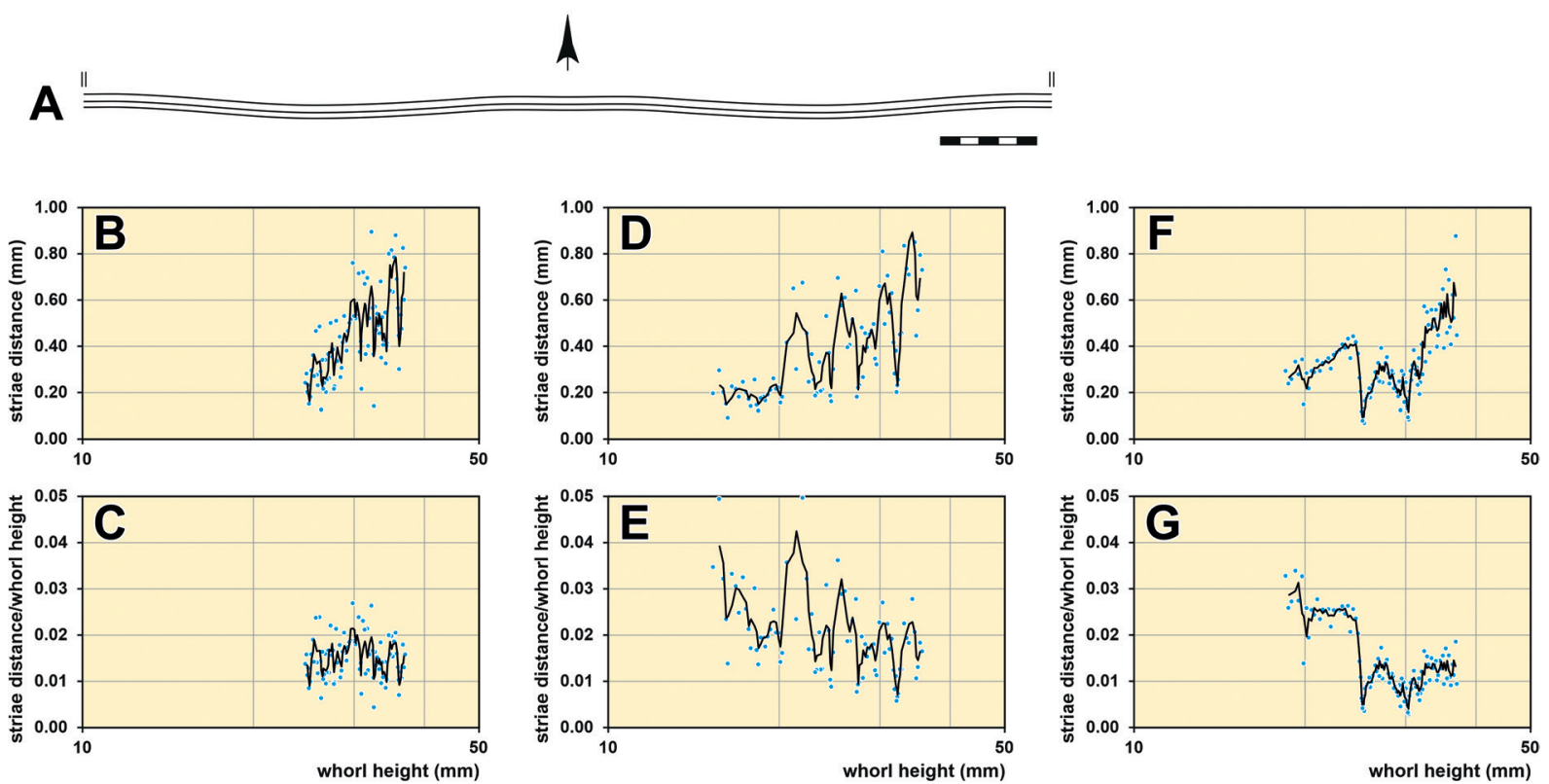

Fig. 16. Rhynchorthoceras kranepuhlense sp. nov. from the Upper Red Orthoceratite Limestone. A. Striae of holotype MB.C.11730 (Kummerow Coll.) from Kranepuhl (Brandenburg), at wh $=16 \mathrm{~mm}$. B-C. Ontogenetic development of striae distance (in $\mathrm{mm}$ ) and striae distance/whorl height of specimen MB.C.30492 (Neben \& Krueger Coll.) from Oderberg (Brandenburg). D-E. Ontogenetic development of striae distance (in $\mathrm{mm}$ ) and striae distance/whorl height of specimen MB.C.30491 (Neben \& Krueger Coll.) from Niederfinow (Brandenburg). F-G. Ontogenetic development of striae distance (in $\mathrm{mm}$ ) and striae distance/whorl height of holotype MB.C.11730 (Kummerow Coll.) from Kranepuhl (Brandenburg). Blue dots $=$ individual measurements, black lines $=$ three data point averaged values. Scale bar units $=1 \mathrm{~mm}$. 


\begin{abstract}
Paratypes
GERMANY • 1 spec.; Brandenburg, Niederfinow; Ordovician, Upper Red Orthoceratite Limestone; Neben and Krueger Coll.; MB.C.30491 • 1 spec.; Brandenburg, Oderberg; Ordovician, Upper Red Orthoceratite Limestone; Neben and Krueger Coll.; MB.C.30492.
\end{abstract}

POLAND • 1 spec.; West Pomerania, Dewitz Castle, Dobra (former Dewitzburg bei Daber); Ordovician, Upper Red Orthoceratite Limestone; MB.C.30493.

\title{
Description
}

Holotype MB.C.11730 (Fig. 15B) is a fragment of an orthoconic phragmocone with $100 \mathrm{~mm}$ length. The conch has a circular whorl profile and expands with an angle of $11^{\circ}$. The shell ornament is preserved along the whole length of the specimen. It consists of transverse striae, which are up to $1.5 \mathrm{~mm}$ apart (at the maximum whorl height of $24 \mathrm{~mm}$ ). The distance of the striae changes irregularly during ontogeny (Fig. 16F-G); at about $10 \mathrm{~mm}$ whorl height, the striae become extremely fine and the conch is slightly constricted at this position (Fig. 15B). The shell wall is slightly undulated in the second half of the specimen. The striae are oblique but straight on the flanks, completely transverse and straight on the venter; they possess a low projection on the dorsum (Fig. 16A). The siphuncle is seen at the latest preserved septum; it is narrow ( 0.12 of whorl height) and central in position.

\section{Remarks}

Rhynchorthoceras kranepuhlense sp. nov. is morphologically closest to R. rugium sp. nov. (described above) because of its striated shell surface. However, the striae in $R$. kranepuhlense sp. nov. stand much closer together and their distance is much more irregular. Also, at places where the distance of the striae is decreased, shallow conch constrictions (Fig. 15B) appear around the conch circumference.

\section{Geographic and stratigraphic occurrence}

Northern Germany and Poland (in erratics within Pleistocene gravels); late Kunda to early Lasnamägi regional stages (middle to late Darriwilian, Middle Ordovician).

\section{Rhynchorthoceras sp.}

\section{Material examined}

GERMANY • 1 spec.; Brandenburg, Eberswalde; Ordovician, Upper Grey Orthoceratite Limestone; MB.C.30510 1 spec.; Brandenburg, Gransee(Ruppin); Ordovician, Upper Grey Orthoceratite Limestone; Kirchner Coll.; MB.C.11689 • 2 specs; Brandenburg, Hohensaaten; Ordovician, Upper Grey Orthoceratite Limestone; Neben and Krueger Coll.; MB.C.30511, MB.C.30512 • 2 specs; Brandenburg, Niederfinow; Ordovician, Upper Grey Orthoceratite Limestone; MB.C.30513, MB.C.30514 • 1 spec.; MecklenburgVorpommern, Dwasieden (Island of Rügen); Ordovician, Upper Grey Orthoceratite Limestone; MfN excursion 1964 Coll.; MB.C.11711 • 1 spec.; Mecklenburg-Vorpommern, Lebbin; Ordovician; Böhm 1906 Coll.; MB.C.11713 • 2 specs; Mark?; Ordovician; MB.C.11705.1, MB.C.11705.2.

POLAND • 1 spec.; Silesia, Kunzendorf; Ordovician; MB.C.11712 • 1 spec.; West Pomerania, Island of Chrząszczewska (former Gristow); Ordovician; MB.C.11710.

SWEDEN • 1 spec.; Island of Öland, Gärdslösa; Ordovician; Bottke Coll.; MB.C.29652.

\section{Remarks}

In the collection under study, there are several specimens of orthoconic or weakly cyrtoconic lituitids, which have expansion angles between $10-14^{\circ}$ (Fig. 13A, Table 2), a circular whorl profile and a 
centrally located siphuncle with SDR between 0.12 and 0.14 (Fig. 13B, Table 3). Thus, the specimens are assigned here to the genus Rhynchorthoceras. Since the shell surface in the above specimens is covered by conspicuously sinuous and asymmetric lirae, which form deep sinuses on the flanks and the venter, they should be assigned either to $R$. breynii from the Middle Ordovician erratics of northern Germany, or the other European species of Rhynchorthoceras with sinuous lirae, i.e., R. beyrichii (from late Darriwilian erratics of Poland), $R$. helgoeyense Sweet, 1958 (from the late Middle or early Late Ordovician of Norway) and $R$. zaddachi (from the Darriwilian erratics of the Kaliningrad Region, Russia). Unfortunately, these species are rare and unequivocally known only from the type material, which has not been revised since the species descriptions and was not available for study herein. In addition, the ornament in the specimens in discussion is often incompletely or poorly preserved. Any species-level assignment of these specimens is thus avoided herein.

Family Lituitidae Phillips, 1848

\section{Diagnosis}

Family of the order Lituitida with coiled apical part of the conch; whorls detached or weakly impressed dorsally. Whorl profile elliptic in the coiled stage, elliptic or circular in the uncoiled stage. Shell surface with growth lines, transverse lirae and/or annuli; ornament elements variable in outline but typically with conspicuous lateral and ventral sinus. Terminal aperture characterised by two to five lappets and deep ventral and lateral sinuses. Siphuncle ventral in the earliest phragmocone chambers, subdorsal in the following part of the coiled stage and subcentral or central in the uncoiled stage (after Furnish \& Glenister 1964).

\section{Genera included}

Ancistroceras Boll, 1857; Angelinoceras Hyatt, 1894; Cyclolituites Remelé, 1886; Holmiceras Hyatt, 1894; Jingshanlingoceras Zou, 1987; Lituites Bertrand, 1763; Pseudoancistroceras Xu \& Lai, 1987; Sinoceroides Xu \& Lai, 1987; Tapinolituites Gao, 1982; Trilacinoceras Sweet, 1958; Yangjiapingoceras $\mathrm{Xu}, 1977$.

Genus Ancistroceras Boll, 1857

\section{Type species}

Lituites undulatus Boll, 1857; by monotypy.

\section{Diagnosis}

Genus of the family Lituitidae with 1.5-2 tightly coiled or only slightly separated early volutions; long, rapidly expanding straight part; umbilical window small. Whorl profile elliptic or circular in the coiled stage, circular in the uncoiled stage. Uncoiled part expands with an angle of $18-35^{\circ}$ and is straight in longitudinal profile. Shell surface with sinuous growth bands and annulations, which form five projections in the coiled part, three and finally two in the straight part. Aperture of mature conch with broad dorsal and ventral projections and shallow lateral sinus (after Aubrechtová \& Meidla 2020).

\section{Species included}

Ancistroceras Barrandei Dewitz, 1880; Ancistroceras Bollii Remelé, 1882; Ancistroceras clinotum Xu \& Lai, 1987; Ancistroceras densum Qi, 1980; Sinoceras fengxiangense Chang, 1964; Ancistroceras magnum Flower, 1975; Ancistroceras ristnensis Aubrechtová \& Meidla, 2020; Ancistroceras subcurvatum Qi, 1980; Strombolituites Torelli Remelé, 1881; Lituites undulatus Boll, 1857; Ancistroceras vahikuelaensis Aubrechtová \& Meidla, 2020. 


\section{Remarks}

The authorship of Ancistroceras is a confusing matter. Boll (1857: 87) stated in the description of his new species Lituites undulatus that he originally planned to define a new genus Ancistroceras for this species, but then changed his mind. However, Boll (1857: 3, fig. 25) presented the species as Ancistroceras undulatum. Dewitz (1880: 387) restored the genus name and designated L. undulatus as the type species. Boll (1857) was then accepted throughout the literature as the author of the genus Ancistroceras. This view is also followed here.

In contrast to Rhynchorthoceras, species of the genus Ancistroceras are characterised by a coiled early juvenile conch, a greater expansion angle, a larger chamber length ratio and a strongly annulated shell surface. Representatives of the genus Holmiceras are similar to species of Ancistroceras, but the former are distinguished by an openly coiled juvenile conch part and a sigmoidally shaped backcoiled part with a smaller expansion angle.

\section{Geographic and stratigraphic occurrence}

North America, Wales (?), Baltoscandia, northern Germany, the Kaliningrad Region of Russia, northern Poland and China; Middle to Late Ordovician. The stratigraphically oldest species of Ancistroceras were described from early Dapingian strata of China and hence belong to the earliest lituitids known to date (Kröger et al. 2007; Fang et al. 2021).

\section{Ancistroceras undulatum (Boll, 1857)}

Figs 17-18, Tables 5-6

\section{Lituites undulatus Boll, 1857: 87.}

Ancistroceras undulatum - Boll 1857: pl. 8 fig. 25a. - Dewitz 1880: 387, pl. 17 fig. 5. - Holm 1885: 21, pl. 3 fig. 2, pl. 4 figs 1, 3-20. — Patrunky 1926: 120. - Foerste 1930: 272, pl. 41 figs 1a-b, 3a-b, 4a-c, pl. 42 figs 3-4. - Balashov 1953: 236, pl. 14 figs 5a-b, 8. — Sweet 1958: 129, pl. 13 figs 2-3, 5, pl. 18 fig. 1. - Zhuravleva 1961: pl. 12 figs 2-3. — Aubrechtová \& Meidla, 2020: 272, text-figs 5-6.

Strombolituites undulatus - Remelé 1881: 191, text-fig. 1; 1882: 11, pl. 5 fig. 1.

Ancistroceras cf. undulatum - Schindewolf 1942: 348, text-fig. 4c.

non Ancistroceras undulatum - Noetling 1884: pl. 18 fig. 6-6a. — Rüdiger 1889: 44. — Balashov 1953:

pl. 14 figs 6-7. — Neben \& Krueger 1971: pl. 17 fig. 1. —Qi 1980: 254, pl. 2 fig. 6, text-fig. 5. non Ancistroceras cf. undulatum - Chen 1987: 178, pl. 6 fig. 18, text-fig. 38.

\section{Diagnosis}

Species of the genus Ancistroceras with a moderately curved end of the coiled part of the conch; uncoiled part conical with an expansion angle of $25-27^{\circ}$. Whorl profile circular throughout ontogeny. Relative chamber length ca 0.35 . Ornament with wide and low annuli (spaced at $2 \mathrm{~mm}$ distance after uncoiling and $4 \mathrm{~mm}$ distance in later growth stages) and lirae $(0.5 \mathrm{~mm}$ in distance after uncoiling and $0.5-1 \mathrm{~mm}$ in distance in later growth stages); crests of annuli commonly with raised pairs of lirae. Course of the lirae with ventral sinus and lateral sinus; dorsal projection roof-shaped and flanked by shallow dorsolateral sinuses. Position of the siphuncle slightly more dorsad in the juvenile part of the conch and gradually relocated to central or almost central position. Connecting rings thin, slightly expanded, siphuncular segments thus slightly constricted at the septal necks (after Aubrechtová \& Meidla 2020, emended). 
Table 4. Conch measurements (in mm), ratios and rates of coiled conch parts of Ancistroceras Boll, 1857.

\begin{tabular}{llcccccc}
\hline taxon & catalogue $\mathbf{~ n r}$ & $\mathbf{d m}$ & $\mathbf{w h}$ & uw & WERdm & WERah & UWI \\
\hline A. barrandei & MB.C.11991a & 17.6 & 8.9 & 4.6 & 4.19 & 4.09 & 0.26 \\
A. torelli & MB.C.22575 & 20.6 & 11.4 & 4.7 & 5.01 & $>3.00$ & 0.23 \\
A. torelli & MB.C.30519 & 19.6 & 11.0 & - & 5.19 & 5.00 & - \\
A. sp. & MB.C.1860 & 23.4 & 13.0 & 5.6 & 4.53 & 5.06 & 0.24 \\
\hline
\end{tabular}

\section{Type material}

Holotype not available for study; Boll (1857: pl. 8 fig. 25) figured one specimen from Usadel near Neubrandenburg (Mecklenburg-Vorpommern, Germany), found in erratics from Pleistocene gravel (Uhaku Regional Stage, late Darriwilian, Middle Ordovician).

\section{Material examined}

GERMANY • 1 spec.; Brandenburg, Niederfinow; Ordovician, Upper Grey Orthoceratite Limestone; Neben 1936 Coll.; MB.C.11696 2 specs; Brandenburg, Oderberg; Ordovician, Upper Grey Orthoceratite Limestone; Neben and Krueger Coll.; MB.C.30520, MB.C.30521.

POLAND - 1 spec.; West Pomerania, Juszkowo (former Gischkau); Ordovician, Upper Grey Orthoceratite Limestone; Neben and Krueger Coll.; MB.C.30522 • 1 spec.; West Pomerania, Skowarcz (former Schönwarling), Gdańsk County; Ordovician; Hoyers 1912 Coll.; MB.C.11697.
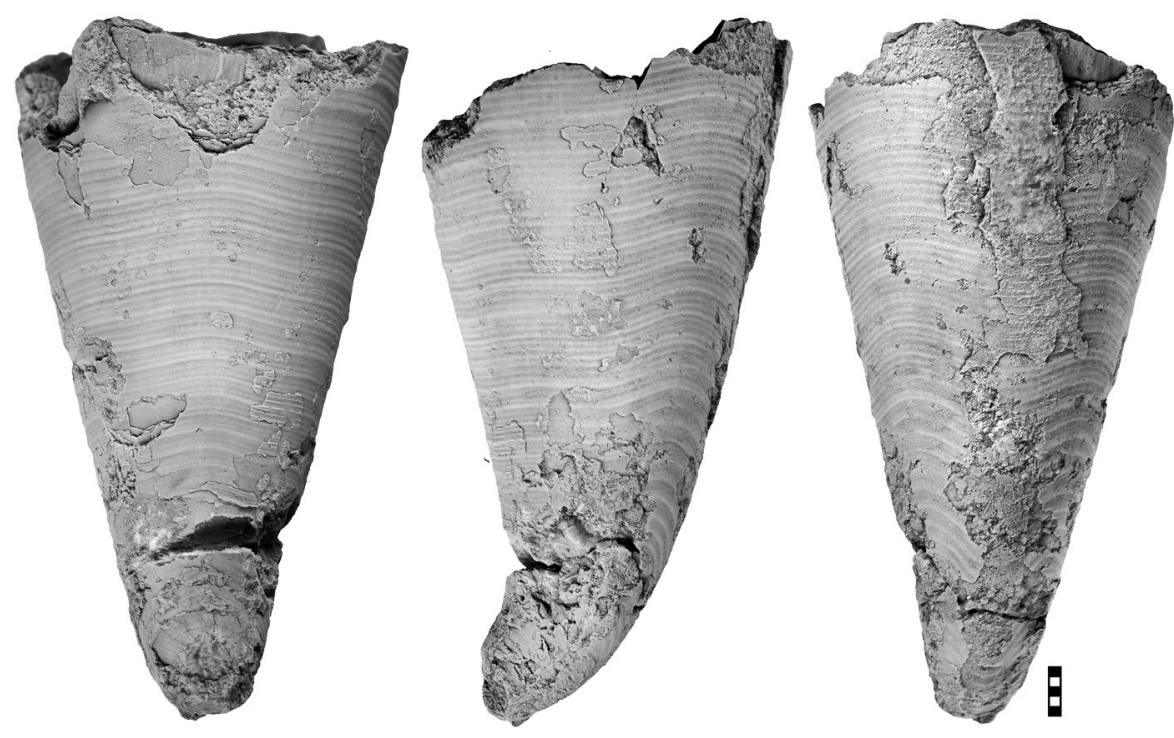

Fig. 17. Ancistroceras undulatum (Boll, 1857) from the Upper Grey Orthoceratite Limestone; specimen MB.C.11697a (Hoyers 1912 Coll.) from Skowarcz (former Schönwarling); previously figured by Foerste (1930: pl. 41 fig. 1); dorsal, lateral and ventral views. Note imprints of the vascular system near the apex visible in the photograph on the left. Scale bar units $=1 \mathrm{~mm}$. 


\section{Description}

The five specimens are fragments of the uncoiled parts of conchs (only the very end of the coiled parts are preserved). The conchs expand with angles of $25-27^{\circ}$ (Fig. 19A). The largest specimen is MB.C.30520, which attains $57 \mathrm{~mm}$ whorl height; at this size, the whorl profile is circular with centrally located siphuncle and an SDR of 0.13 (Fig. 19B). The shell ornament is preserved in all specimens. It consists of annuli (up to $3.5 \mathrm{~mm}$ apart), which bear raised pairs of lirae (up to $1 \mathrm{~mm}$ apart) on their crests. The ornament elements form a ventral sinus, lateral sinuses and a dorsal projection that is roof-shaped and flanked by low dorsolateral sinuses (Figs 17-18).

\section{Remarks}

Ancistroceras undulatum is very similar to A. barrandei (described below), from which it differs chiefly in the weaker curvature at the end of the coiled part of the conch (Aubrechtová \& Meidla 2020). However, the present material reveals further differences in the shell ornament: the dorsal projection is roof-shaped, flanked by low dorsolateral sinuses in A. undulatum. By contrast, the dorsal projection in A. barrandei is continuously rounded and lacks dorsolateral sinuses.

Specimen MB.C.11687 is the largest Ancistroceras in the collection with the length of $226 \mathrm{~mm}$ and maximum whorl height of $49 \mathrm{~mm}$. The conch is, however, incompletely preserved and the specimen is thus assigned to $A$. cf. undulatum.

A regular network of radial lines and impressions is preserved in the posterior surface of cameral deposits in the specimen MB.C.11696. These were interpreted as remains of a vascular system by Aubrechtová \& Meidla (2020: fig. 5f-g). The same structures are found also in the specimen MB.C.11697a (Fig. 17).

\section{Geographic and stratigraphic occurrence}

Norway, Sweden, Estonia (in situ) and northern Germany, northern Poland and the Kaliningrad Region (Russia) (in erratics within Pleistocene gravels); Lasnamägi, Uhaku and early Kukruse regional stages (Darriwilian to early Sandbian, Middle to early Late Ordovician).

Ancistroceras undulatum is a stratigraphically significant species in Baltoscandia indicating the Uhakuan age (e.g., Jaanusson 1960; Evans et al. 2014).

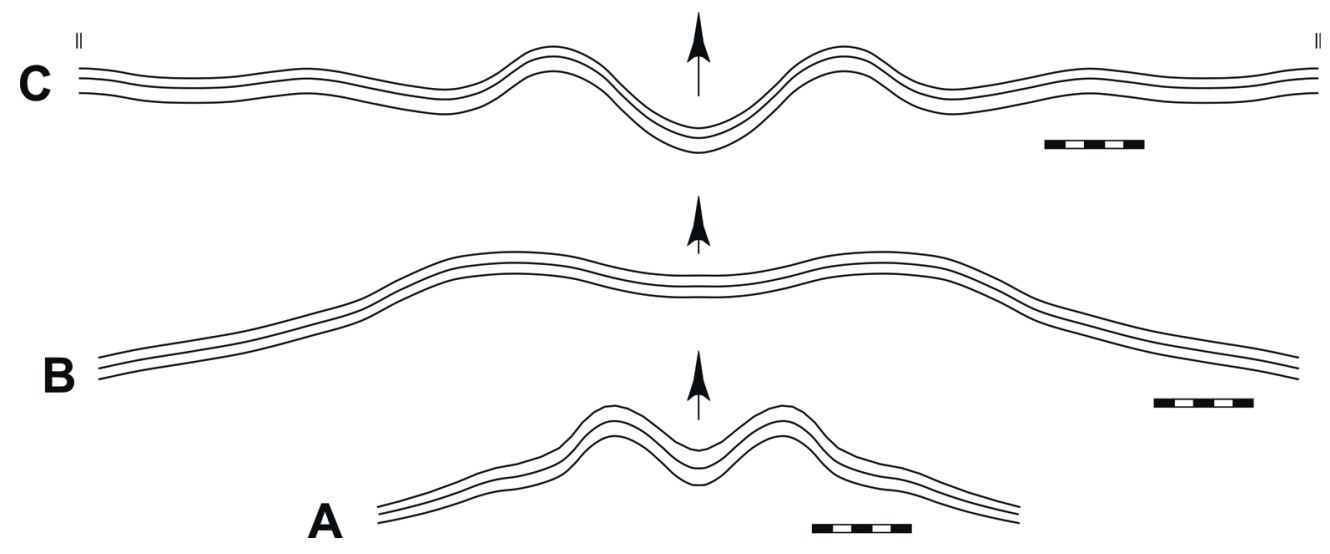

Fig. 18. Ancistroceras undulatum (Boll, 1857), lirae course in selected specimens. A. Specimen MB.C.30522 (Neben \& Krueger Coll.) from Juszkowo (former Gischkau), Gdańsk County (Pomerania, Poland), at $w h=10 \mathrm{~mm}$. B. The same specimen, at $w h=27 \mathrm{~mm}$. C. Specimen MB.C.30521 (Neben \& Krueger Coll.) from Oderberg (Brandenburg), at $w h=18 \mathrm{~mm}$. Scale bar units $=1 \mathrm{~mm}$. 
Table 5. Conch measurements (in $\mathrm{mm}$ ), and expansion rates of uncoiled conch parts of Ancistroceras Boll, 1857.

\begin{tabular}{|c|c|c|c|c|c|c|c|}
\hline taxon & catalogue nr & max. wh & max. ww & min. wh & min. ww & $\begin{array}{l}\text { fragm. } \\
\text { length }\end{array}$ & $\mathbf{E A}\left(^{\circ}\right)$ \\
\hline A. barrandei & MB.C. 11700 & - & 38.0 & - & 17.5 & 48.2 & 24.0 \\
\hline A. barrandei & MB.C.11991a & 27.1 & - & 11.4 & 10.4 & 53.5 & 16.7 \\
\hline A. barrandei & MB.C.30516 & 40.0 & - & 9.6 & 8.5 & 84.5 & 20.4 \\
\hline A. barrandei & MB.C.30517 & 35.7 & 35.4 & 7.0 & - & 71.2 & 22.8 \\
\hline A. barrandei & MB.C.30518 & 45.0 & 46.0 & 13.0 & 13.3 & 99.3 & 18.3 \\
\hline A. torelli & MB.C. 22575 & 32.0 & - & 17.5 & 16.0 & 25.3 & 32.0 \\
\hline A. torelli & MB.C.30519 & 30.7 & 32.5 & 17.0 & 18.0 & 26.5 & 29.0 \\
\hline A. undulatum & MB.C.11696 & 29.0 & - & 8.0 & 8.0 & 47.4 & 25.0 \\
\hline A. undulatum & MB.C.11697a & 32.0 & - & 10.0 & - & 47.8 & 25.9 \\
\hline A. undulatum & MB.C.30521 & 39.0 & 39.0 & 15.2 & 15.2 & 49.6 & 27.0 \\
\hline A. undulatum & MB.C.30520 & 57.0 & 57.0 & 16.0 & - & 87.7 & 26.3 \\
\hline A. undulatum & MB.C.30522 & 36.0 & - & 14.0 & - & - & - \\
\hline A. cf. barrandei & MB.C.11692.1, 3 & 39.1 & - & 21.1 & - & 36.1 & 28.0 \\
\hline A. cf. undulatum & MB.C.11687 & 49.0 & - & 14.4 & - & 72.0 & 27.0 \\
\hline A. cf. undulatum & MB.C.11692.2, 4 & 28.8 & - & 14.6 & - & 24.8 & 32.0 \\
\hline A. cf. undulatum & MB.C.30565 & 38.0 & 40.0 & 14.0 & 15.3 & 54.1 & 25.0 \\
\hline A. cf. undulatum & MB.C.30564 & 45.0 & 46.0 & 10.5 & 11.0 & 81.5 & 23.9 \\
\hline A. sp. & MB.C.30566 & 54.0 & - & 11.0 & 11.0 & 89.5 & 27.0 \\
\hline
\end{tabular}

Ancistroceras barrandei Dewitz, 1880

Figs 20-22, 23A-C, Tables 4-6

Ancistroceras Barrandei Dewitz, 1880: 389, pl. 17 fig. 6-6a.

Strombolituites Barrandei-Remelé 1881: 192.

Ancistroceras Barrandei-Noetling 1884: 128. - Patrunky 1926: 120.

Ancistroceras undulatum - Noetling 1884: pl. 18 fig. 6-6a. — Rüdiger 1889: 44. — Qi 1980: 254, pl. 2

fig. 6, text-fig. 5. — Neben \& Krueger 1971: pl. 17 fig. 1

Endoceras barrandei - Foerste 1930: 300.

Ancistroceras barrandei - Neben \& Krueger 1971: pl. 21 fig. 9.

\section{Diagnosis}

Species of the genus Ancistroceras with strongly curved end of the coiled part of the conch, expansion angle of straight part $17-21^{\circ}$. Tubular connecting rings. Dorsal projection of ornament elements continuously rounded, without dorsolateral sinuses (after Aubrechtová \& Meidla 2020, emended).

\section{Type material}

Not available for study; Dewitz (1880) mentioned three specimens, one of them was figured (Dewitz 1880: pl. 17 fig. 6), from Mayakovskoye (former Nemmersdorf; Kaliningrad Region, Russia), Middle Ordovician erratics from Pleistocene gravel. 


\section{Material examined}

GERMANY • 1 spec.; Brandenburg, Heegermühle; Ordovician; MB.C.11700 • 1 spec.; Brandenburg, Niederfinow; Ordovician, Upper Grey Orthoceratite Limestone; Neben and Krueger Coll.; MB.C.30515 - 1 spec.; Mecklenburg-Vorpommern, Groß Zicker (Island of Rügen); Ordovician, Upper Grey Orthoceratite Limestone; Helms 1966 Coll.; MB.C.11991a • 2 specs; Mecklenburg-Vorpommern, Rerik (Ostsee); Ordovician, Upper Grey Orthoceratite Limestone; MB.C.30516, MB.C.30517 • 1 spec.; Mecklenburg-Vorpommern, Rerik (Ostsee); Ordovician, Upper Grey Orthoceratite Limestone; Neben and Krueger 1971 Coll.; MB.C.30518.

\section{Description}

Specimen MB.C.30518 (Figs 21A, 23A) consists of the coiled part ( $\mathrm{dm}=12 \mathrm{~mm}$; inner whorls not preserved, last quarter of the last whorl detached from preceding whorl) and a part of the straight uncoiled part of the conch (length $=140 \mathrm{~mm}$; wh $=45 \mathrm{~mm}$; EA $\sim 18^{\circ}$ ). The shell ornament in the coiled and beginning of the uncoiled part consists of annuli $(1 \mathrm{~mm}$ apart $)$ that bear raised pairs of lirae $(0.3-0.5 \mathrm{~mm}$ apart) on their crests. In the remaining part of the uncoiled conch, the annuli are wide and flat and the lirae are standing up to $1.3 \mathrm{~mm}$ apart. The dorsal projection of ornament elements is low and continuously rounded, i.e., not flanked by dorsolateral sinuses. The length of the phragmocone chambers can be measured only in the middle part of the straight part (CLR $=0.34$ at $w h=40.5 \mathrm{~mm})$.

Specimen MB.C.11991 (Figs 21C, 23C) consists of the almost complete coiled part ( $\mathrm{dm}=15 \mathrm{~mm}$; coiling tight, only the last part of the last volution is detached; WER $=4.20$ ) and a part of the weakly sigmoid uncoiled part (length $=90 \mathrm{~mm}$; wh $=27 \mathrm{~mm}$; EA $\left.\sim 17^{\circ}\right)$. The shell ornament consists of narrow annuli (up to $1.4 \mathrm{~mm}$ in distance) and lirae (up to $0.3 \mathrm{~mm}$ in distance) in the coiled part and beginning of the uncoiled part; the annuli become wider and applanate in the remaining uncoiled part; the distance of lirae increases up to $1 \mathrm{~mm}$. The ventral sinus is deep but becomes shallower during ontogeny. On the flanks, the ornament elements extend transversely with a lateral sinus that develops at a whorl height of ca $17 \mathrm{~mm}$. The dorsal projection is low, continuously rounded and is not flanked by any dorsolateral sinuses. The chamber length increases during ontogeny $(C L R=0.32-0.42)$.
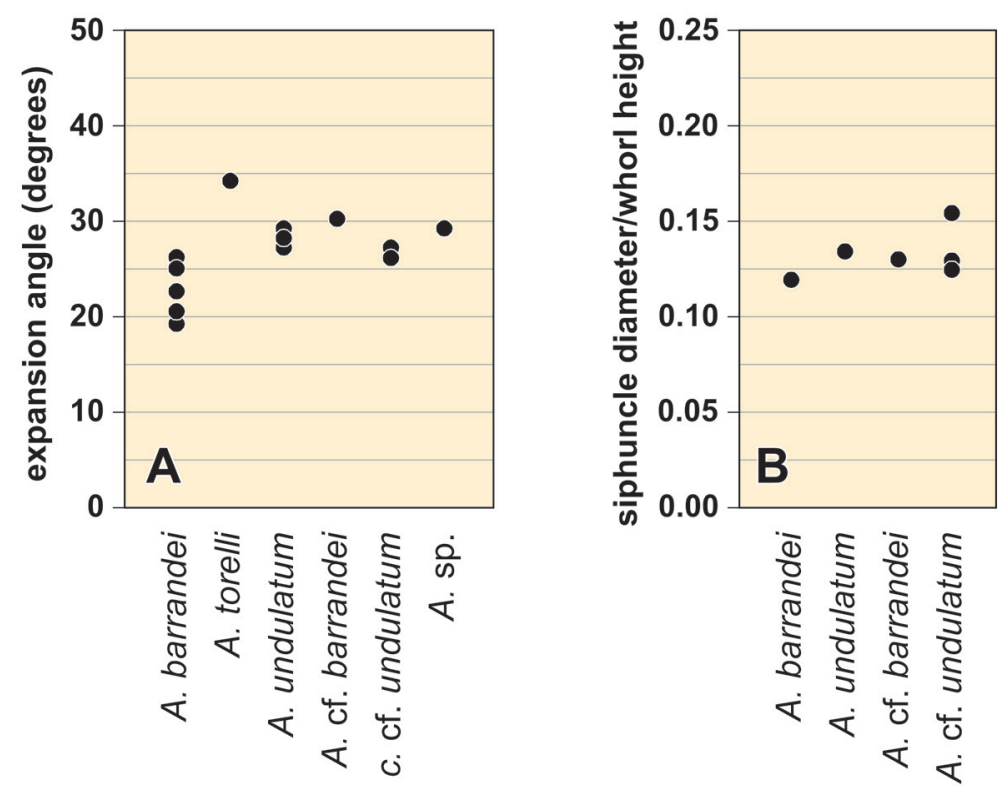

Fig. 19. Conch expansion rates (A) and siphuncle diameter rates (B) in species of Ancistroceras Boll, 1857. 
Specimen MB.C.30516 (Figs 21B, 23B) consists of the almost complete coiled part (inner whorls are tightly coiled and the last whorl widely detaches from preceding whorls; $\mathrm{dm}=10 \mathrm{~mm}$ ) and a part of the straight uncoiled part (length $=115 \mathrm{~mm}$; wh $=40 \mathrm{~mm}$; EA $\sim 20^{\circ}$ ) of the conch. The shell ornament in the coiled part of the specimen and after uncoiling consists of indistinct annuli and raised pairs of lirae (up to $0.5 \mathrm{~mm}$ apart). In the larger half of the specimen, the annuli are very wide and flat, and the shell surface is ornamented by slightly irregularly developed lirae (up to $0.7 \mathrm{~mm}$ apart). The ornament elements form deep sinuses on the venter and flanks of the conch; the dorsal projection is low and continuously rounded. The chamber length is variable (CLR $=0.16-0.33)$ and decreases towards the aperture (Fig. 22).

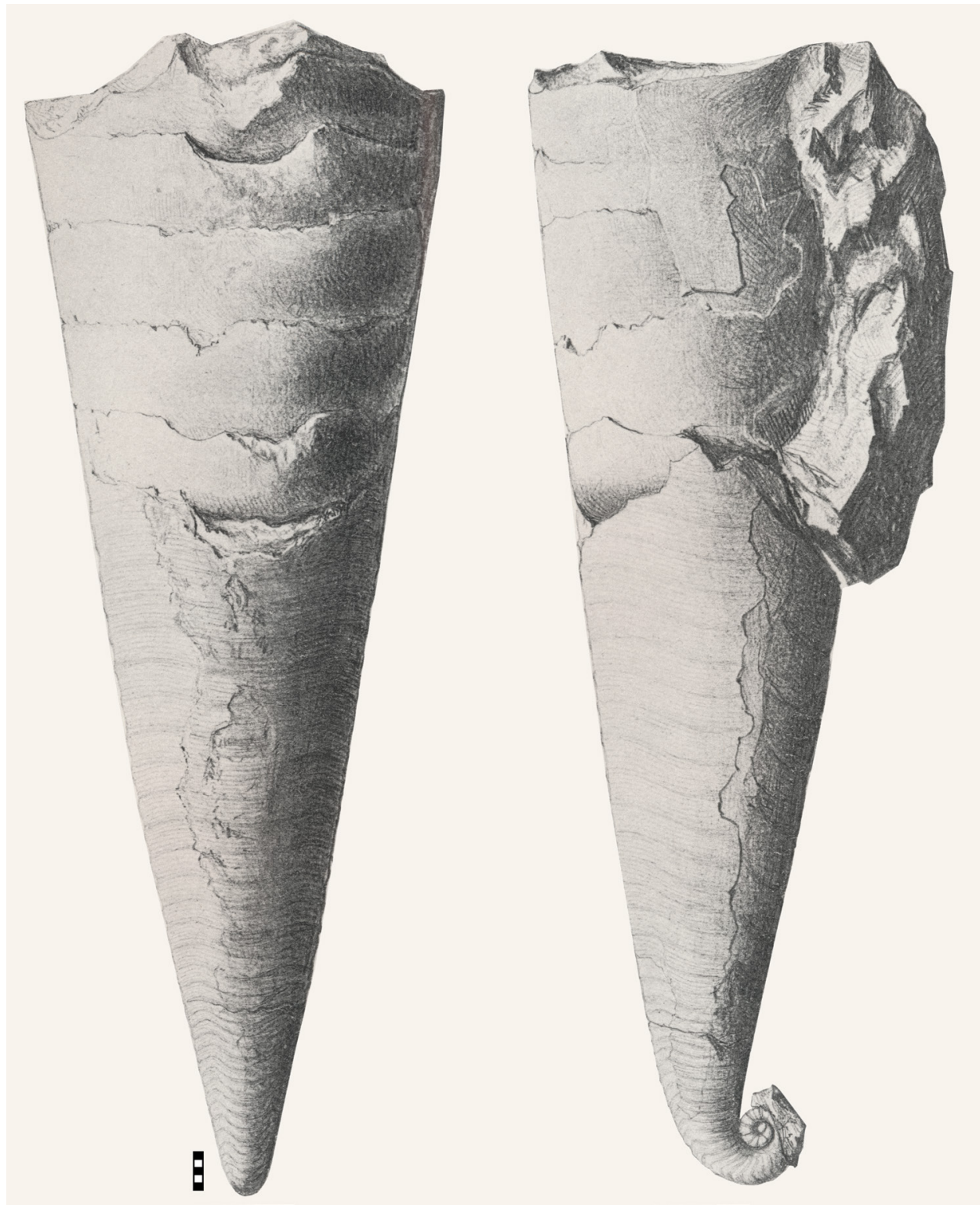

Fig. 20. Ancistroceras barrandei Dewitz, 1880, reproduction of the figure provided by Noetling (1884: pl. 16 Fig. 6-6a). Scale bar units $=1 \mathrm{~mm}$. 


\section{Remarks}

Ancistroceras barrandei is very similar to A. undulatum (described above), from which it differs in the stronger curvature at the end of the coiled part of the conch (Aubrechtová \& Meidla 2020). The specimens studied here also show that the dorsal projection of the ornament is continuously rounded
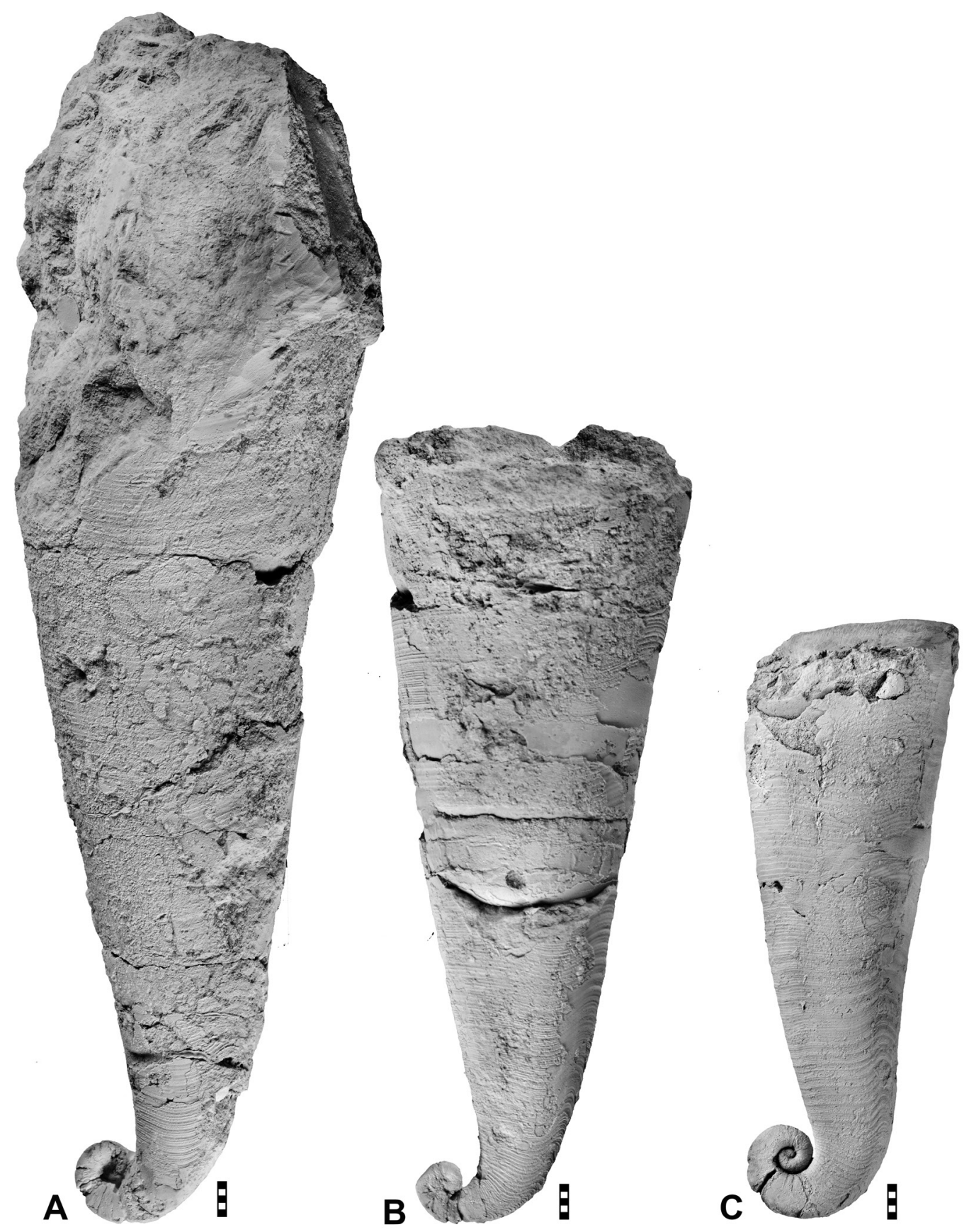

Fig. 21. Ancistroceras barrandei Dewitz, 1880 from the Upper Grey Orthoceratite Limestone. A. Specimen MB.C.30518 (Neben \& Krueger Coll.) from Rerik (Ostsee); previously figured by Neben \& Krueger (1971: pl. 17 fig. 1). B. Specimen MB.C.30516 (Neben \& Krueger Coll.) from Rerik (Ostsee). C. Specimen MB.C.11991 (Helms 1966 Coll.) from Groß Zicker (Island of Rügen). Scale bar units = $1 \mathrm{~mm}$. 

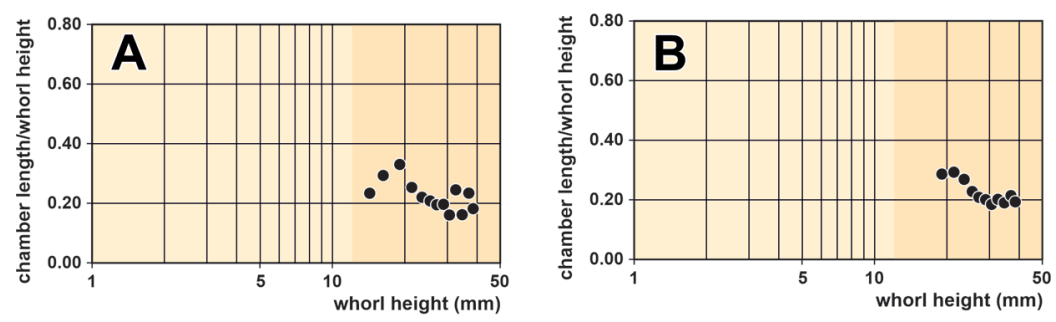

Fig. 22. Ancistroceras barrandei Dewitz, 1880, chamber length/whorl height of specimen MB.C.30516 (Neben \& Krueger Coll.) from Rerik (Ostsee). Left $=$ empirical data, right $=$ three data point averaged.

without dorsolateral sinuses in $A$. barrandei, while the dorsal projection is roof-shaped with shallow adjacent dorsolateral sinuses in $A$. undulatum.

In $A$. barrandei, the coiled conch is so far known only from a single specimen (Noetling 1884: pl. 18 fig. 6) (Fig. 20). Here, we describe additional specimens with preserved coiled parts. Their morphology is variable in the degree to which the last whorl loses contact with the preceding whorl (Fig. 23). In other characters, the specimens are similar to each other.

Specimen MB.C.11991 has a weakly sigmoid uncoiled part of the conch and a rather low expansion angle $\left(17^{\circ}\right)$, which might suggest it should be assigned to Holmiceras. However, the specimen has a tightly, not loosely coiled apical part of the conch and at the conch length of $90 \mathrm{~mm}$, it does not reach the mature growth stage.

\section{Geographic and stratigraphic occurrence}

Estonia (in situ) and northern Germany, northern Poland and the Kaliningrad Region (Russia) (in erratics within Pleistocene gravels); Aseri to Uhaku regional stages, Middle Ordovician. According to Dewitz (1880), the type material of $A$. barrandei comes from the "lower Silurian" of Königsberg (= Kaliningrad), where it was found in co-occurrence with Ancistroceras undulatum. The co-occurrence of the two species suggests a late Darriwilian age.

\section{Ancistroceras torelli (Remelé, 1881)}

Figs 23D-E, 24-25, Tables 4-5

Strombolituites Torelli Remelé, 1881: 192, text-fig. 2.

Ancistroceras Torelli - Noetling 1884: pl. 18 fig. 7. - Holm 1885: pl. 4 fig. 2. - Remelé 1890: pl. 4 fig. 1.

Ancistroceras torelli - Balashov 1962: pl. 9 fig. 8. — Neben \& Krueger 1971: pl. 17 figs 2, 7.

? Ancistroceras torelli - Foerste 1930: pl. 41 fig. 2a-b. — Dzik 1984: pl. 39 figs 8-9, pl. 40 figs 1-2.

\section{Diagnosis}

Species of the genus Ancistroceras with strongly curved end of the coiled part of the conch; uncoiled part of the conch straight; expansion angle ca $30^{\circ}$. Whorl profile slightly depressed in the coiled part and circular in the uncoiled part of the conch. Ornament with distinct, narrow annuli and lirae, welldeveloped even in the coiled part of the conch. Ornament with shallow lateral sinus, low dorsal projection and ventral sinus; the latter deep at the coiled part and flattened out in the uncoiled part of the conch. 
Table 6. Siphuncular diameter ratio (SDR) and siphuncular distance ratio (SPR) at their corresponding whorl height in specimens of Ancistroceras Boll, 1857.

\begin{tabular}{llcccc}
\hline taxon & catalogue $\mathbf{~ r}$ & wh & SDR & wh & SPR \\
\hline A. barrandei & MB.C.11700 & 38.0 & 0.12 & 38.0 & 0.41 \\
A. undulatum & MB.C. 30521 & - & - & 41.0 & 0.56 \\
A. undulatum & MB.C.30520 & 57.0 & 0.13 & 57.0 & 0.49 \\
A. cf. barrandei & MB.C.11692.1, 3 & 32.5 & 0.13 & 32.5 & 0.50 \\
A. cf. undulatum & MB.C. $11692.2,4$ & 21.5 & 0.15 & 21.5 & 0.52 \\
A. cf. undulatum & MB.C. 30565 & 14.0 & 0.13 & 14.0 & 0.41 \\
A. cf. undulatum & MB.C. 30564 & 10.5 & 0.12 & 10.5 & 0.48 \\
\hline
\end{tabular}
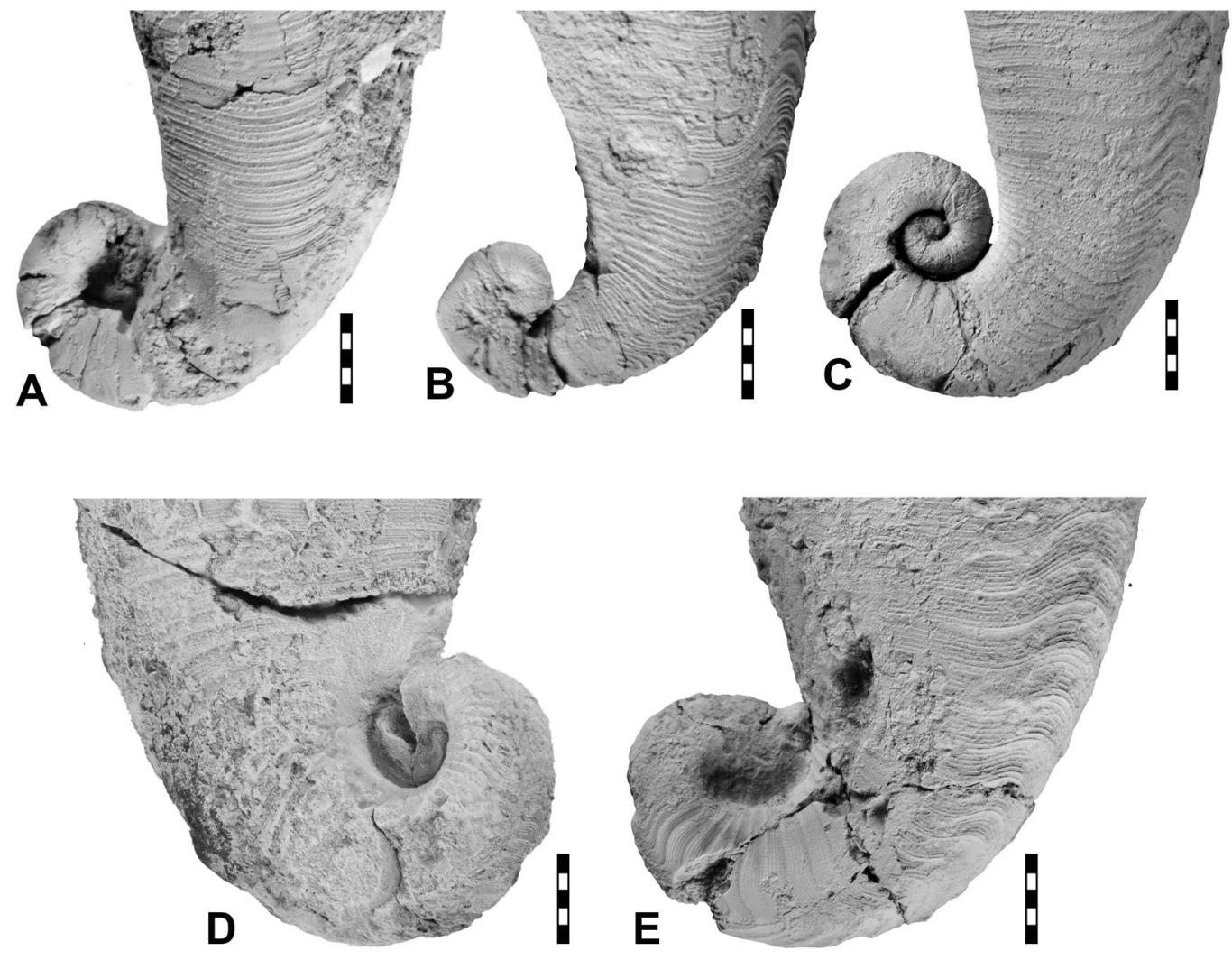

Fig. 23. Comparison of the coiled parts of species of Ancistroceras Boll, 1857 from the Upper Grey Orthoceratite Limestone. A. Ancistroceras barrandei Dewitz, 1880, specimen MB.C.30518 (Neben \& Krueger Coll.) from Rerik (Ostsee). B. Ancistroceras barrandei Dewitz, 1880, specimen MB.C.30516 (Neben \& Krueger Coll.) from Rerik (Ostsee). C. Ancistroceras barrandei Dewitz, 1880, specimen MB.C.11991 (Helms 1966 Coll.) from Groß Zicker (Island of Rügen). D. Ancistroceras torelli (Remelé, 1881), lectotype MB.C.22575 from Heegermühle (Brandenburg). E. Ancistroceras torelli (Remelé, 1881), specimen MB.C.30519 (Neben \& Krueger Coll.) from Schmetzdorf (Brandenburg). Scale bar units $=1 \mathrm{~mm}$. 


\section{Type material}

\section{Lectotype (designated here)}

GERMANY • Brandenburg, Heegermühle; erratics in Pleistocene gravel, Ordovician, Upper Grey Orthoceratite Limestone; illustrated by Remelé (1881: text-fig. 2; 1890: pl. 4 fig. 1) and Neben \& Krueger (1971: pl. 17 fig. 7); re-illustrated here in Fig. 23D, 24, 25A; MB.C.22575.

\section{Paralectotype}

GERMANY • Brandenburg, Schmetzdorf; Ordovician, Upper Grey Orthoceratite Limestone; Neben and Krueger Coll.; MB.C.30519.

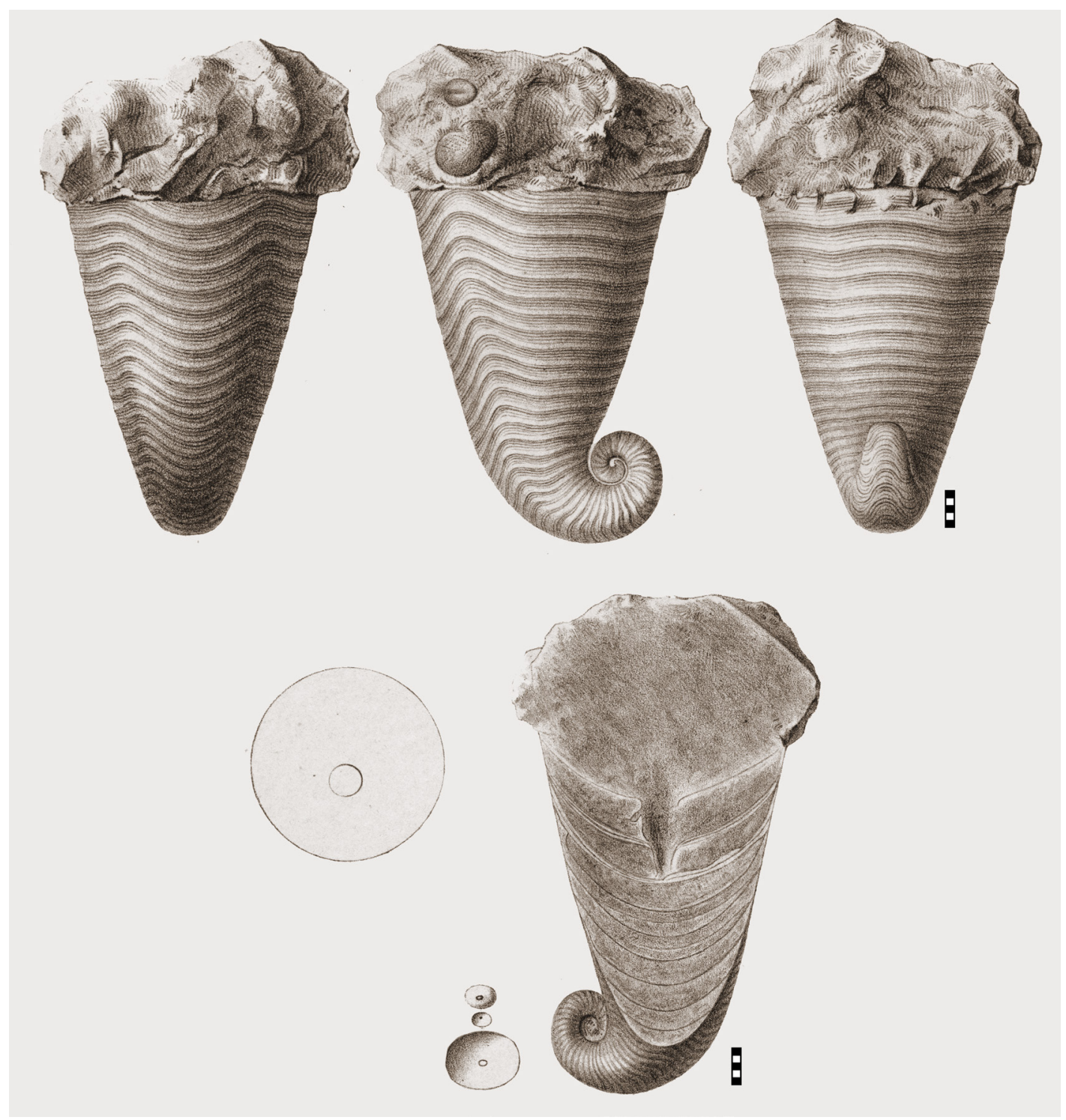

Fig. 24. Ancistroceras torelli (Remelé, 1881) from the Upper Grey Orthoceratite Limestone. Reproduction of the illustration of lectotype MB.C.22575 from Heegermühle (Brandenburg) from Remelé (1890: pl. 4 fig. 1). Scale bar units $=1 \mathrm{~mm}$. 


\section{Description}

Lectotype MB.C.22575 (Figs 23D, 24, 25A) is undeformed but some measurements are difficult to obtain because of an imprecise, oblique section that was ground by a previous researcher. The conch consists of the coiled part $(\mathrm{dm}=20.5 \mathrm{~mm}$; tightly coiled; WER $>3)$ and the straight uncoiled part (length $=33 \mathrm{~mm}$ long; $w \mathrm{wh} 32 \mathrm{~mm}$; EA $\sim 32^{\circ}$ ). The shell ornament consists of raised lines in the coiled part of the conch, but towards the uncoiled part of the conch, these lines grade into narrow but clearly marked annuli ( $2.5 \mathrm{~mm}$ apart) with lirae $0.5 \mathrm{~mm}$ apart. The chamber length can be measured precisely only at the end of the uncoiled part of the specimen (CLR $=0.18$ at wh $=28 \mathrm{~mm}$ ). The siphuncle has a central position and measures ca 0.12 of the whorl height.

Paralectotype MB.C.30519 (Figs 23E, 25B) is similar in size to the lectotype. The conch consists of the coiled part $(\mathrm{dm}=19.7 \mathrm{~mm}$; tightly coiled; WER $\sim 5)$ and the straight uncoiled part (length $=41 \mathrm{~mm}$; $\mathrm{wh}=31 \mathrm{~mm} ; \mathrm{EA} \sim 29^{\circ}$ ). The shell ornament consists of narrow annuli that are clearly visible along the whole extension of the conch including the coiled part. Their distances increase gradually from $0.7 \mathrm{~mm}$ to $2.5 \mathrm{~mm}$. The annuli are accompanied by lirae $(0.5 \mathrm{~mm}$ apart). The ornament elements form a low dorsal projection, a shallow lateral sinus and a ventral sinus, which is deep in the coiled part and flattens out in the uncoiled part.

\section{Remarks}

Unlike the other species of the genus, Ancistroceras torelli has distinctly developed annuli even in the coiled part of the conch. Additionally, the species differs from the above described A. undulatum in the stronger curvature at the end of the coiled part and from $A$. barrandei in a much larger expansion angle $\left(\right.$ ca $30^{\circ}$ ). Ancistroceras bollii (Remelé, 1882) from the Darriwilian erratics of northern Germany has a more bulbous conch than A. torelli and it is generally smaller, ventrally curved and retains the circular whorl profile during ontogeny.
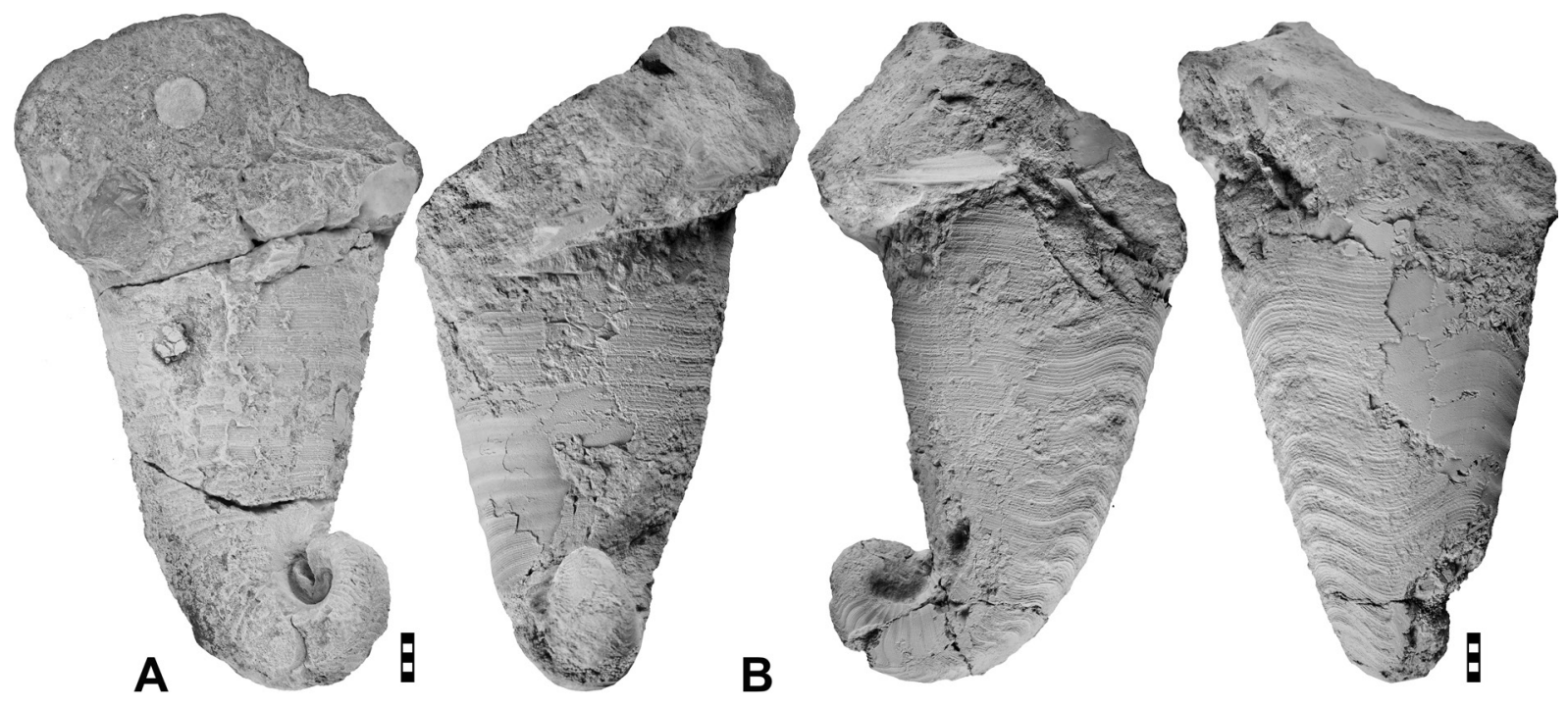

Fig. 25. Ancistroceras torelli (Remelé, 1881) from the Upper Grey Orthoceratite Limestone. A. Lectotype MB.C.22575 from Heegermühle (Brandenburg); dorso-lateral view. B. Specimen MB.C.30519 (Neben \& Krueger Coll.) from Schmetzdorf (Brandenburg); dorsal, lateral and ventral views. Scale bar units $=1 \mathrm{~mm}$. 


\section{Geographic and stratigraphic occurrence}

Northern Germany and northern Poland (in erratics within Pleistocene gravels); late Darriwilian, Middle Ordovician.

According to Remelé (1881), the lectotype originated from the "light grey orthoceratite limestone", where it co-occurs with Lituites perfectus and the trilobites Asaphus sp., Illaneus sp. and Hoplolichas tricuspidatus Beyrich, 1846. This co-occurrence suggests a late Darriwilian (probably Lasnamägian) age of the lectotype.

Genus Angelinoceras Hyatt, 1894

\section{Type species}

Lituites latus Angelin, 1880; subsequent designation by Sweet (1958).

\section{Diagnosis}

Genus of the family Lituitidae with loosely coiled apical part of the conch, 30 to over $50 \mathrm{~mm}$ in diameter, and moderately expanded (ca $8^{\circ}$ ) sigmoidal backcoiled part. Whorl profile compressed throughout (WWI $\sim 0.90$ at the last whorl). Whorl expansion rate based on whorl height decreases during ontogeny from 3.00 to 2.00. Ornament with regularly spaced narrow annuli/raised lirae and finer lirae in between; annuli with deep ventral sinus, prominent ventrolateral projections, broad and asymmetric lateral sinuses, low dorsolateral projections, and a broad, nearly straight dorsal sinus subdivided, at least in the early stages, by a mid-dorsal projection. Ventral band with ventrolateral ridges may be present (after Sweet 1958; Furnish \& Glenister 1964).

\section{Species included}

Only the type species.

\section{Remarks}

Fang et al. (2021) proposed, among others, to synonymise Angelinoceras with Lituites. The species of the two genera are indeed similar, essentially differing only in the conch size (coiled conch diameters in Angelinoceras may exceed $50 \mathrm{~mm}$ ). The herein studied material is, however, too incomplete in preservation to make a proper decision on this matter.

The genus Angelinoceras consists only of the type species A. latum. This species is known from the middle Darriwilian strata of mainland Sweden and the Island of Öland, and also from erratics in Germany that derived from Darriwilian rocks of Baltoscandia. With its narrow stratigraphic range, A. latum is a stratigraphically significant taxon in Baltoscandia (e.g., Jaanusson \& Mutvei 1953; Evans et al. 2014).

Sweet (1958) described a probable second, stratigraphically younger species from the Ampyx Limestone of the Oslo-Asker district (Sandbian, early Late Ordovician). However, because of its fragmentary preservation, he assigned this specimen as Angelinoceras sp. Aceñolaza et al. (1977) reported Angelinoceras sp. from the San Juan Formation (Middle Ordovician) of the Argentine Precordillera, but that specimen differs in the geometry of the coiled conch part and has a lower expansion rate than characteristic representatives of Angelinoceras. In fact, based on the photograph provided by Aceñolaza et al. (1977: pl. 1g), it seems the specimen might actually belong to the family Estonioceratidae (order Tarphyceratida Flower, 1950), rather than the lituitids. 


\section{Geographic and stratigraphic occurrence}

Norway and Sweden (in situ) and northern Germany and northern Poland (in erratics within Pleistocene gravels); Kunda to early Kukruse regional stages (Middle to early Late Ordovician).

\section{Angelinoceras latum (Angelin, 1880)}

Figs 26-28, Table 7

Lituites latus Angelin, 1880: 9, pl. 11 figs 1-4.

Lituites Hageni Remelé, 1880: 228, pl. 1 figs 4-5, pl. 3 fig. 3.

Lituites Hageni-Remelé 1890: 19, pl. 1 figs 4-5, pl. 3 fig. 3.

Lituites latus - Jaanusson \& Mutvei 1953: 18, fig. 3b.

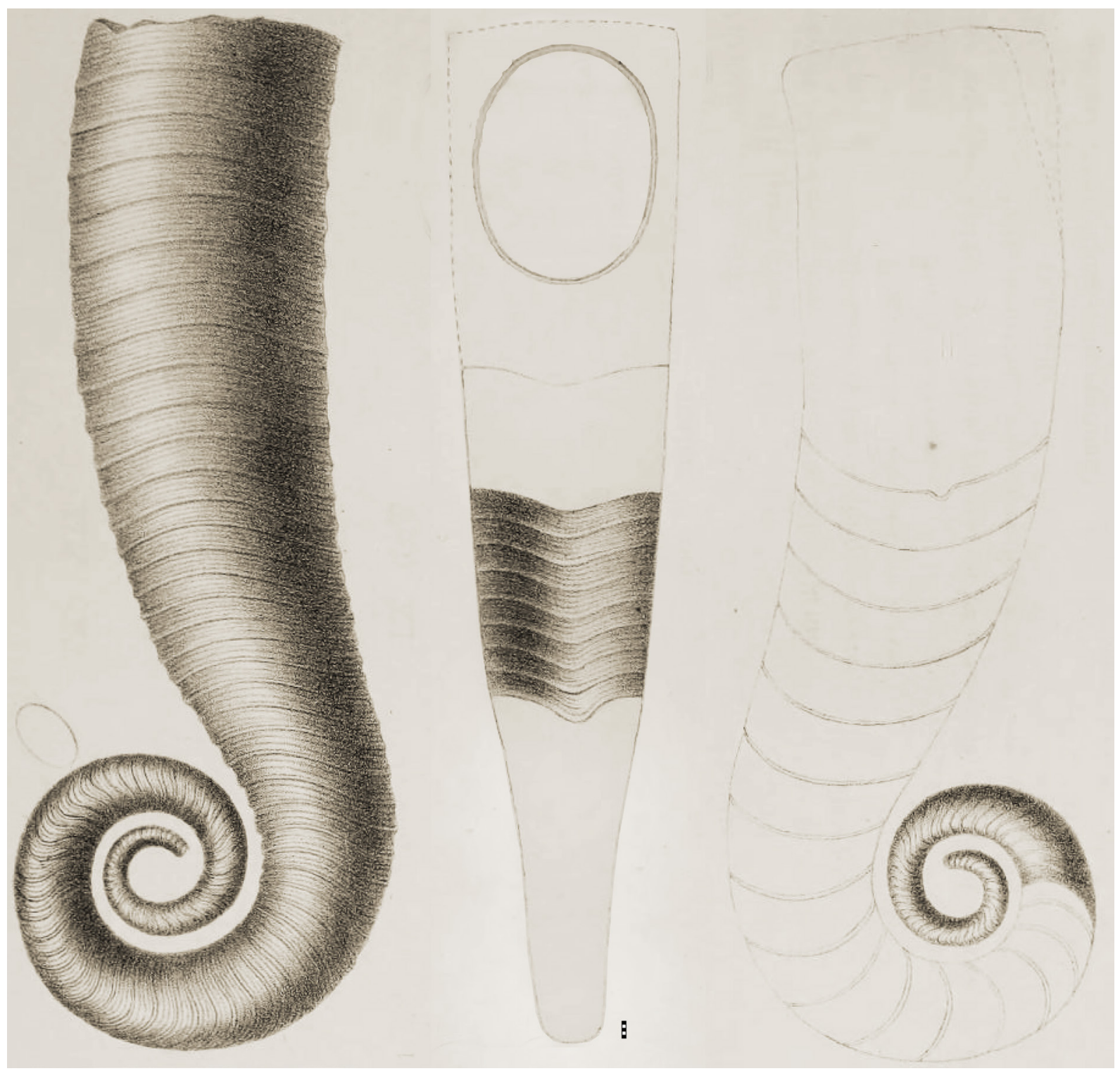

Fig. 26. Angelinoceras latum (Angelin, 1880); reproduction of illustrations by Angelin (1880: pl. 3 fig. 5). Scale bar units $=1 \mathrm{~mm}$. 
Table 7. Conch measurements (in mm), ratios and rates of coiled conch parts of Angelinoceras Hyatt, 1894.

\begin{tabular}{lccccccccc}
\hline taxon & catalogue $\mathbf{~ n r}$ & $\mathbf{d m}$ & wh & uw & ww & WERdm & WERah & UWI & WWI \\
\hline A. latum & MB.C.11681 & - & 19.7 & 21.0 & - & - & - & - & - \\
A. latum & MB.C.11682 & 52.2 & - & 18.6 & 21.9 & - & 2.63 & 2.41 & 0.42 \\
A. latum & MB.C.11683 & 53.6 & 16.0 & 18.2 & 24.7 & 47.2 & - & 2.29 & 0.46 \\
A. latum & MB.C.30525 & 41.5 & 15.0 & 16.0 & 15.8 & 39.0 & 3.15 & 2.65 & 0.38 \\
A. sp. & MB.C.29658 & 32.9 & - & 11.0 & - & 21.7 & 2.20 & 2.26 & - \\
\hline
\end{tabular}

Angelinoceras latum - Sweet 1958: 132. - Balashov 1962: pl. 7 fig. 2.

Lituites hageni - Neben \& Krueger 1971: pl. 21 figs 4-5.

Lituites cf. hageni - Neben \& Krueger 1971: pl. 21 fig. 6.

\section{Diagnosis}

As for the genus.

\section{Type material}

\section{Lectotype}

Not re-studied; the specimen figured by Angelin (1880: pl. 11 figs 1-4; illustration reproduced here in Fig. 26), from Vikarbyn (Dalarna, Sweden) and was found in the lower part of the Segerstad Limestone (Upper Red Orthoceratite Limestone, Aseri Regional Stage, middle Darriwilian, Middle Ordovician; designated and re-illustrated by Jaanusson \& Mutvei (1953: 18, fig. 3b).

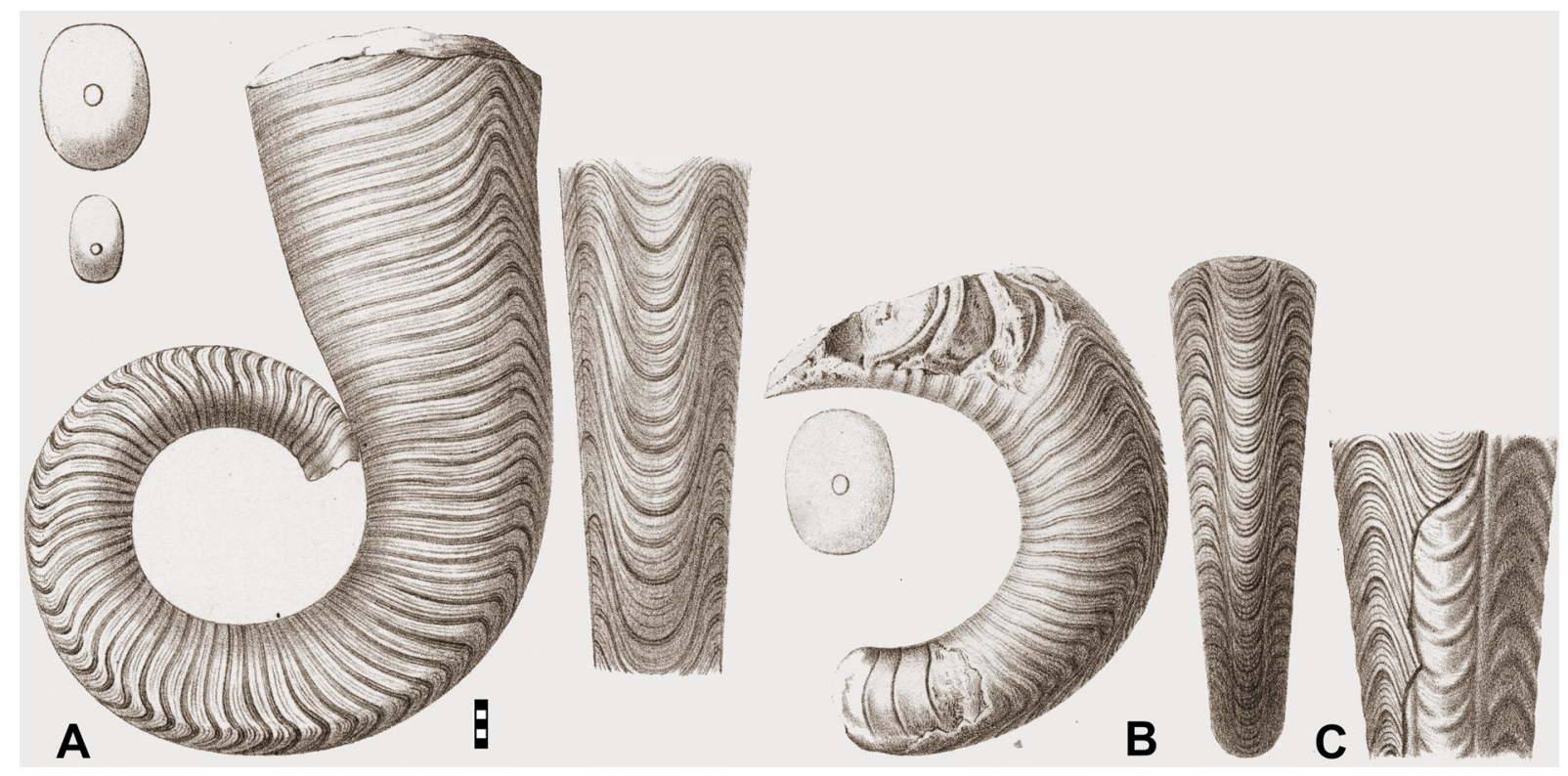

Fig. 27. Angelinoceras latum (Angelin, 1880); reproductions of illustrations of Remelé (1890). A. Specimen MB.C.11682 from Eberswalde (Brandenburg), illustrated by Remelé (1890: pl. 1 fig. 4). B. Specimen MB.C.11683 from Heegermühle (Brandenburg), illustrated by Remelé (1890: pl. 3 fig. 3). C. Specimen MB.C.11681 from Eberswalde (Brandenburg), illustrated by Remelé (1890: pl. 1 fig. 5). Scale bar units $=1 \mathrm{~mm}$. 


\section{Material examined}

GERMANY - 1 spec.; Brandenburg, Vierraden (Schwedt); Ordovician, Upper Grey Orthoceratite Limestone; Krueger 1974 Coll.; MB.C.11687 • 1 spec.; Brandenburg, Eberswalde; Ordovician; MB.C.11681 • $1 \mathrm{spec}$.; Brandenburg, Eberswalde railway station; Ordovician, Upper Red Orthoceratite Limestone; Remelé 1878 Coll.; MB.C.11682 • 1 spec.; Brandenburg, Heegermühle; Ordovician, Upper Red Orthoceratite Limestone; Kgl. Forstakademie Eberswalde Coll.; MB.C.11683 • 2 specs; Brandenburg, Niederfinow; Ordovician, Upper Red Orthoceratite Limestone; MB.C.30523, MB.C.30524 • 1 spec.; Brandenburg, Oderberg; Ordovician, Upper Red Orthoceratite Limestone; Neben Coll.; MB.C.30525.

POLAND • 1 spec.; Silesia, probably Żory (former Sorau); Ordovician, Upper Red Orthoceratite Limestone; Kirchner Coll.; MB.C.11684.

\section{Description}

The seven specimens are fragments of the last whorl of the coiled part (coiling tight at least in the last whorl; 42-54 mm in diameter; WWI $\left.=0.88-0.94 ; \mathrm{WER}_{\mathrm{ah}}=2.30-2.60 ; \mathrm{WER}_{\mathrm{dm}}=2.60-3.10\right)$. Only the specimen MB.C.11682 (Fig. 28A) has a short part of the uncoiled part (27 mm long; $29 \mathrm{~mm}$ whorl height) of the conch. The shell ornament consists of narrow annuli (up to $2 \mathrm{~mm}$ apart) and fine lirae in between (up to $1 \mathrm{~mm}$ apart); a ventral band flanked by ventrolateral ridges is formed on the venter (Fig. 27). Annuli may have pairs of raised lirae on their crests.

\section{Remarks}

Three of the seven specimens (MB.C.11681-MB.C.11683; Fig. 27) studied here are syntypes of Lituites hageni from Darriwilian erratics of northern Germany. Rüdiger (1889) and Dzik (1984) suggested that L. hageni is a junior synonym of Angelinoceras latum. This view is followed and supported here because the syntypes of L. hageni differ from the lectotype of A. latum (Fig. 26) only in the larger diameter of their coiled parts. Moreover, the additional specimen MB.C.30525, figured by Neben \& Krueger (1971: pl. 21 fig. 6), is even smaller than the lectotype, while closely resembling all other investigated specimens.

\section{Geographic and stratigraphic occurrence}

Sweden (in situ) and northern Germany and northern Poland (in erratics within Pleistocene gravels); upper Kunda to Aseri (possibly up to lower Lasnamägi) regional stages (middle to late Darriwilian, Middle Ordovician).

\section{Angelinoceras sp.}

Fig. 28B, Table 7

\section{Material examined}

GERMANY - 1 spec.; Brandenburg, Oderberg; Ordovician, Upper Red Orthoceratite Limestone; Krueger Coll.; MB.C.29658.

\section{Description}

Specimen MB.C.29658 (Fig. 28B) consists of the coiled part (coiling tight; $33 \mathrm{~mm}$ diameter; WWI = $0.66 ; \mathrm{WER}_{\mathrm{dm}}=2.20$ and $\mathrm{WER}_{\mathrm{ah}}=2.30$ ) of a conch. The shell surface is only locally and indistinctly preserved. Narrow annuli are separated by very thin lirae and both form a deep ventral sinus, which is delineated by paired longitudinal grooves. 

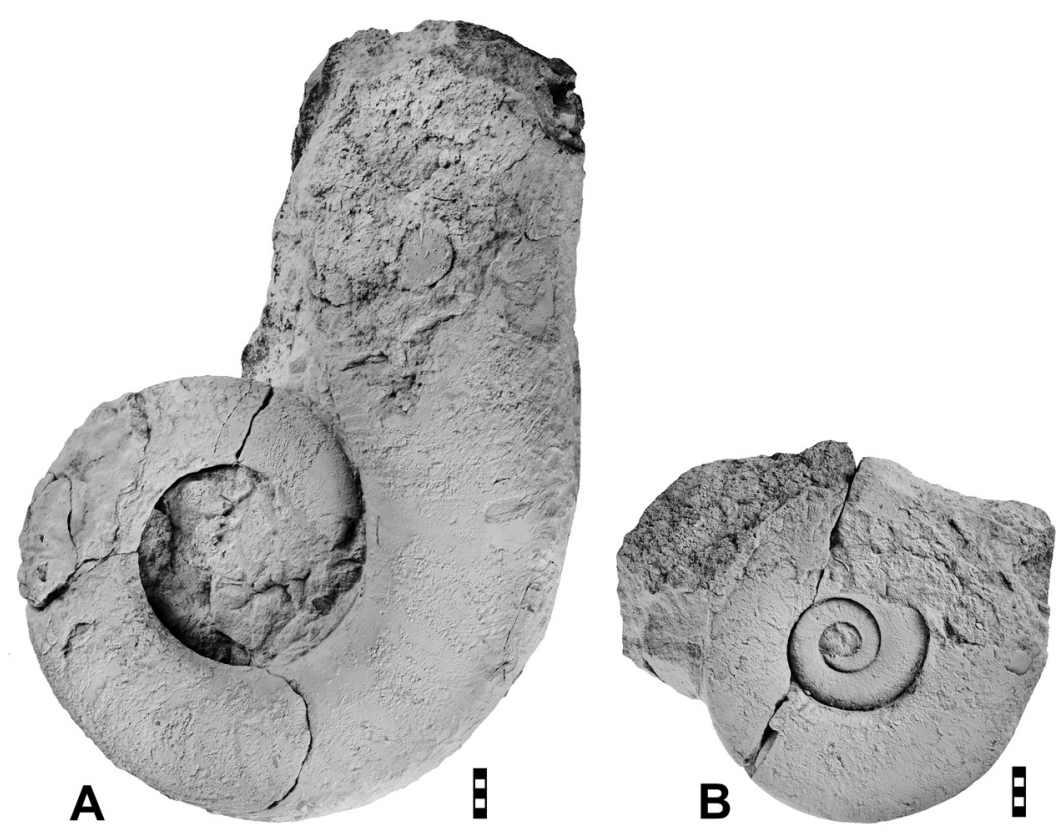

Fig. 28. Angelinoceras Hyatt, 1894 from the Upper Red Orthoceratite Limestone. A. Angelinoceras latum (Angelin, 1880), specimen MB.C.11682 (Remelé 1878 Coll.) from Eberswalde (Brandenburg); lateral view. B. Angelinoceras sp., specimen MB.C.29658 (Krueger Coll.) from Oderberg (Brandenburg). Scale bar units $=1 \mathrm{~mm}$.

\section{Remarks}

The specimen represents an Angelinoceras as indicated by its conch ratios and type of ornament. The specimen differs from A. latum in the smaller, tightly coiled conch with a slightly lower whorl expansion rate. The incomplete preservation of the last whorl and of the early uncoiled part makes it difficult to decide whether the specimen should be assigned to a new species or whether it only reflects morphological variation within A. latum.

Genus Holmiceras Hyatt, 1894

\section{Type species}

Lituites praecurrens Holm, 1891; subsequent designation by Sweet (1958).

\section{Diagnosis}

Genus of the family Lituitidae with 1 to 1.5 loosely coiled volutions of the coiled conch; uncoiled part short, sigmoidal, with expansion angles of $7^{\circ}-20^{\circ}$. Whorl profile either slightly compressed or somewhat depressed. Chamber length between 0.20 and 0.30 of the whorl height. Shell surface with annuli and/or lirae; lateral and dorsal sinuses and ventrolateral and dorsolateral projections in the apical parts of the conch, but adorally, the ventral and dorsal sinuses disappear so, that on the mature body chamber, the venter and dorsum are occupied by broad projections (after Sweet 1958). 


\section{Species included}

Holmiceras benneti Flower, 1975; Orthoceras coreanicum Kobayashi, 1928; Lituites Kjerulfi Brøgger, 1882; Lituites praecurrens Holm, 1891; Holmiceras sichuanense Lai, 1986; Holmiceras havelense sp. nov.

\section{Remarks}

The species of Holmiceras are morphologically closely similar to species of Ancistroceras, which have a smaller and tightly coiled juvenile conch and attain greater expansion angles (usually between 20 and $30^{\circ}$ ). The conch shapes in the species of Holmiceras are also somewhat similar to those in Angelinoceras because the uncoiled conch in both genera expands rapidly. The species of Angelinoceras have much larger general dimensions, though, with coiled conch diameters of $30-50 \mathrm{~mm}$. The species of the genus Lituites generally have lower expansion angles (Fig. 30), larger overall conch sizes and mature aperture with five projections and deep sinuses on the ventral and lateral sides of the conch. Sweet (1958), Dzik (1984) and Fang et al. (2021) discussed the phylogenetic relationships of Holmiceras in greater detail.

\section{Geographic and stratigraphic occurrence}

Canada, Norway, Sweden, northern Germany, Korea and China; Middle to Late Ordovician.

The type species $H$. praecurrens is a stratigraphically significant species in the Orthoceratite Limestone of Baltoscandia, indicating a Kundan age (Evans et al. 2014).

Holmiceras havelense sp. nov. urn:1sid:zoobank.org:act:C92771A7-17B5-4838-8B38-62884C9AAA5C

Fig. 29, Table 8

Lituites aff. praecurrens - Neben \& Krueger 1971: pl. 21 figs 2-3.
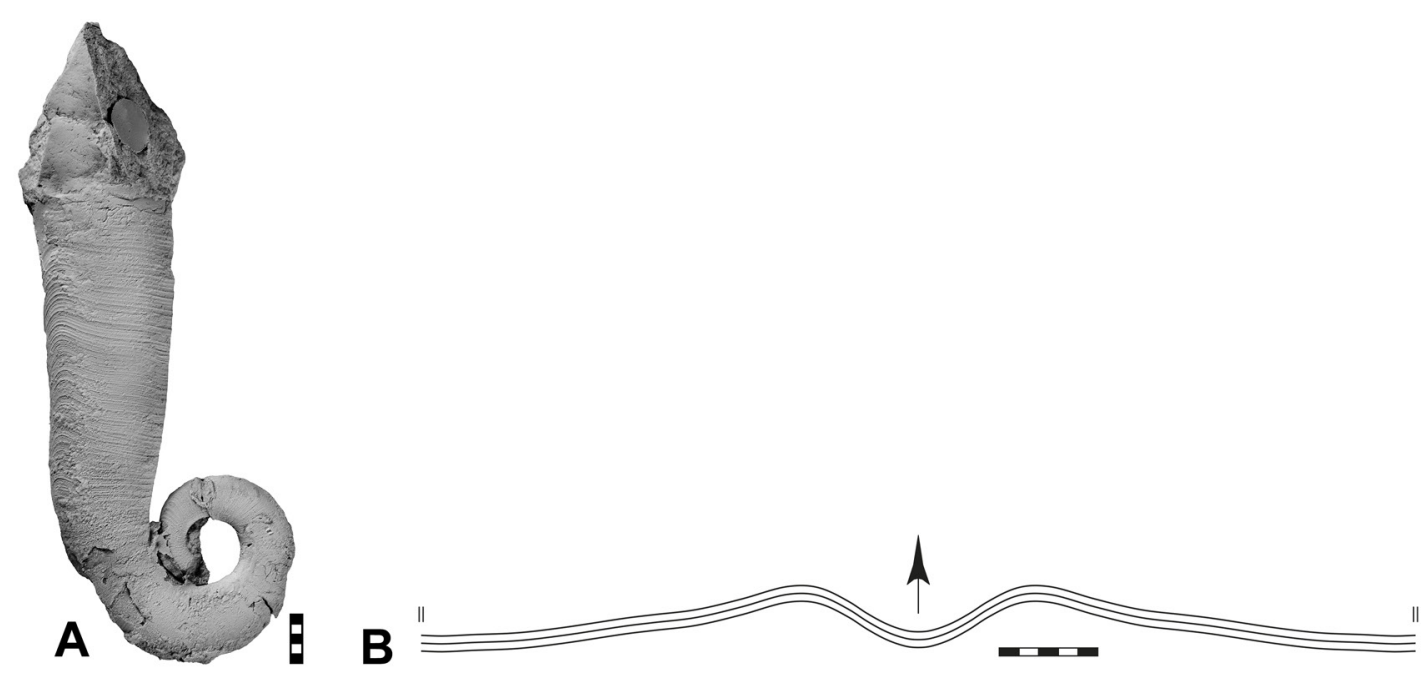

Fig. 29. Holmiceras havelense sp. nov. from the Upper Red Orthoceratite Limestone. A. Holotype MB.C.30526 (Neben \& Krueger Coll.) from Werder (Brandenburg); previously figured by Neben \& Krueger (1971: pl. 21 figs 2-3). B. Lirae of holotype MB.C.30526 at wh $=14 \mathrm{~mm}$. Scale bar units = $1 \mathrm{~mm}$. 
Table 8. Conch measurements (in mm), ratios and rates of coiled conch parts of Holmiceras Hyatt, 1894.

\begin{tabular}{llcccccccc}
\hline taxon & catalogue $\mathbf{~ n r}$ & $\mathbf{d m}$ & wh & uw & ww & WERdm & WERah & UWI & WWI \\
\hline H. havelense & MB.C.30526 & 20.6 & 7.8 & 7.8 & - & 2.85 & 2.59 & 0.38 & - \\
\hline
\end{tabular}

\section{Diagnosis}

Species of the genus Holmiceras with coiled part $21 \mathrm{~mm}$ in diameter; uncoiled part nearly straight; expansion angle $7^{\circ}$. Shell surface with growth lines and fine, irregularly spaced lirae.

\section{Etymology}

From the river Havel, which flows through the type region.

\section{Type material}

\section{Holotype}

GERMANY - Brandenburg, Werder (Potsdam); Ordovician, Upper Red Orthoceratite Limestone; Neben and Krueger Coll.; previously illustrated by Neben \& Krueger (1971: pl. 21 figs 2-3), reillustrated here in Fig. 29A; MB.C.30526.

\section{Description}

Holotype MB.C.30526 (Fig. 29A) consists of the coiled part ( $\mathrm{dm}=21 \mathrm{~mm}$; coiling probably loose, the end of the last volution nearly in contact with the preceding whorl; $\mathrm{WER}_{\mathrm{ah}}=2.60 ; \mathrm{WER}_{\mathrm{dm}}=2.90$ ) and a short part of the almost straight uncoiled part (length $=29 \mathrm{~mm}$; wh $=14 \mathrm{~mm}$; EA $\sim 7^{\circ}$ ). The delicate shell ornament consists of growth lines and thin lirae, some of which are more raised than others; any prominent annulation is absent. The lirae are laterally oblique, sloping towards the dorsal side; the ventral sinus is deep and rounded and the dorsal projection is flat (Fig. 29B). The CLR is between 0.20 and 0.25 .

\section{Remarks}

Specimen MB.C.30526 fits in the diagnosis of Holmiceras but differs from all species of this genus in the more delicate ornament and a much smaller expansion angle of the uncoiled conch part $\left(7^{\circ}\right.$ in the new species but $20^{\circ}$ in the others).

\section{Geographic and stratigraphic occurrence}

The holotype is from Werder (Brandenburg, Germany) and comes from erratics (Aseri Regional Stage, middle Darriwilian, Middle Ordovician) in Pleistocene gravel.

Genus Lituites Bertrand, 1763

\section{Type species}

Lituites lituus de Montfort, 1808; by original designation.

\section{Diagnosis}

Genus of the family Lituitidae with tightly or loosely coiled apical part of the conch; uncoiled part straight or variably curved; expansion angle up to ca $8^{\circ}$. Whorl profile compressed in the coiled and backcoiled part and circular in the straight part of the conch. Shell surface with sinuous annuli and/or lirae. Siphuncle position changes from subdorsal to subcentral during ontogeny. Fully mature aperture 
with a pair of pronounced ventrolateral lappets, similar but shorter dorsolateral lappets and a low dorsal projection (after Furnish \& Glenister 1964, emended).

\section{Species included}

Lituites anguinus Angelin, 1880; Lituites anhuiense Qi, 1980; Lituites baculus sp. nov.; Lituites bottkei sp. nov.; Lituites clavis sp. nov.; Lituites dewitzi sp. nov.; Lituites evolutus Fang, Chen \& Zhang in Fang et al., 2017; Lituites fallax Remelé, 1890; Lituites hengshanensis Qi, 1980; Lituites kruegeri sp. nov.; Lituites lii Yü, 1930; Lituites Lasaulxii Remelé, 1890; Lituites lituus de Montfort, 1808; Lituites nebeni sp. nov., Lituites ningkiangense Lai, 1965; Lituites perfectus Wahlenberg, 1818; Lituites procerus Remelé, 1890; Lituites tenuicaulis Remelé, 1890; Lituites Törnquisti Holm, 1891; Lituites wuweiense Qi, 1980 (synonym of L. ningkiangense Lai, 1965); Lituites xizangense Lai, 1982.

\section{Remarks}

Most species of the genus Lituites known from Baltoscandia and erratics in north central and eastern Europe were described already in the $19^{\text {th }}$ century. Differences between the species concern mainly the mode of coiling, the shape of the whorl profile, the degree of curvature of the backcoiled part, the expansion angle and the shell ornament (Aubrechtová \& Meidla 2020: 278, table 2). However, the apparently high intraspecific variation and common morphological transitions between the species make it often difficult to distinguish between them. An additional problem is that the species were originally defined based on the coiled and backcoiled parts of the conch. The straight part and mature aperture are not known in most of the species, which makes it impossible to taxonomically determine specimens consisting only of the uncoiled part (Holm 1891).

\section{Geographic and stratigraphic occurrence}

Argentina, Baltoscandia, northern Germany, northern Poland, Kaliningrad Region of Russia, Bohemia, Lhasa Terrane (North Tibet), North and South China; Middle to Late Ordovician.

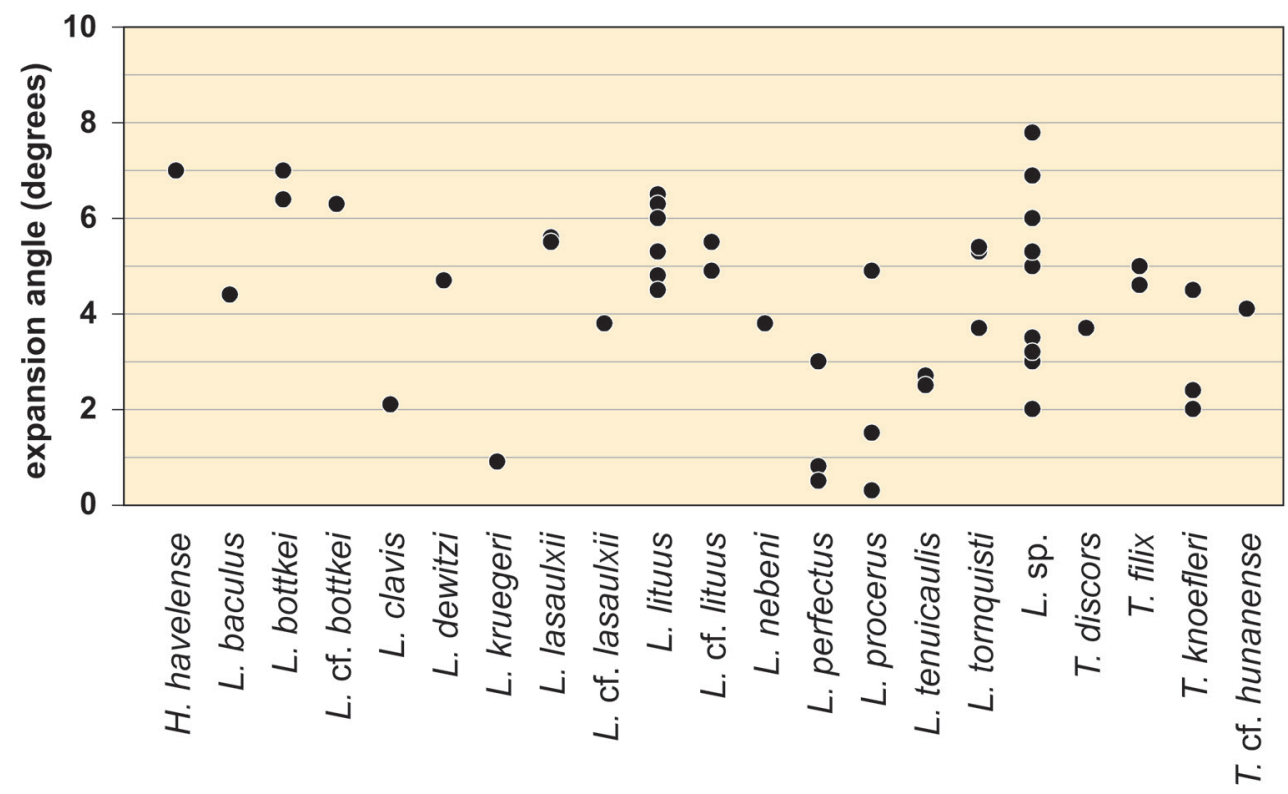

Fig. 30. Conch expansion rates in species of the Lituitidae Phillips, 1848. 
Lituites lituus de Montfort, 1808

Figs 31-32, 33A-B, 34-35, Tables 9-10

Lituites lituus de Montfort, 1808: 278, text-fig. on p. 278.

Lituites lituus - Lossen 1860: 15, pl. 1a-d. — Remelé 1880: 432; 1890: 7, pl. 1 fig. 1. — Angelin 1880: 8, pl. 9 fig. 8. - Noetling 1882: 156, pl. 11 fig. 1. - Holm 1891: 20, pl. 3 figs 1-2. - Sweet 1958: 141, pl. 14 fig. 5, pl. 15 fig. 4. - Neben \& Krueger 1971: pl. 31 fig. 1. — Dzik 1984: 137, pl. 41 fig. 1. - Aubrechtová \& Meidla 2020: 279, text-figs 9, 10f, h-i, k.

Lituites procerus - Balashov 1953: 233, pl 14 fig. 2; 1962: pl. 7 fig. 9.

\section{Diagnosis}

Species of the genus Lituites with coiled conch ca $25-30 \mathrm{~mm}$ in diameter; coiling tight or whorls slightly detached. Backcoiled part of the conch moderately to strongly curved, expansion angle ca $5^{\circ}$. Straight part of the conch orthoconic or slightly cyrtoconic with expansion angle ca $8^{\circ}$. Shell ornament with coarse annuli, clearly developed along the whole length of the conch including the coiled part and terminal body chamber; growth lines and lirae present in between the annuli. Ornament elements rectiradiate or weakly prorsiradiate (backcoiled part); ventral sinus moderately deep, lateral sinus comparatively wider and shallower, dorsolateral sinus shallow, dorsal projection low.

\section{Type material}

\section{Neotype}

GERMANY - Brandenburg, Oderberg (Bralitz); Ordovician (late Lasnamägi Regional Stage, late Darriwilian), Upper Grey Orthoceratite Limestone; Neben and Krueger Coll.; previously illustrated by Neben \& Krueger (1971: pl. 31 fig. 1), re-illustrated here in Fig. 33A; MB.C.30527.

\section{Additional material}

GERMANY • 1 spec.; near Berlin; Ordovician; MB.C.11639 • 1 spec.; Mecklenburg-Vorpommern, Bansin (Gothensee, Usedom); Ordovician; v. Mensebach Coll.; MB.C.11657 • 2 specs; MecklenburgVorpommern, Groß Zicker (Island of Rügen); Ordovician, Upper Grey Orthoceratite Limestone; Krueger 1966 Coll.; MB.C.2497, MB.C.11990.

SWEDEN • 1 spec.; Södra Sandby, Skåne; Ordovician, Seby Limestone (transition between the Upper Red and Upper Grey Orthoceratite Limestone); Bottke Coll.; MB.C.29650.

ESTONIA • 1 spec.; Karula, Lääne-Viru County; Ordovician, Upper Grey Orthoceratite Limestone; Dames 1876 Coll.; MB.C.9714.

COUNTRY UNKNOWN • 1 spec.; "West Prussia"; Ordovician, Echinosphaerites Limestone; Kiesow 1901 Coll.; MB.C.30528 • 1 spec.; Ordovician; MB.C.11640.

\section{Description}

Neotype MB.C.30527 (Figs 33A, 34A-E) consists of the coiled part (2.5 tightly coiled volutions; $\mathrm{dm}=$ $29 \mathrm{~mm} ; \mathrm{WER}_{\mathrm{dm}}=2.17, \mathrm{WER}_{\mathrm{ah}}=2.14 ; \mathrm{WWI}=0.86$ at $\mathrm{wh}=9 \mathrm{~mm}$ ) and the moderately curved uncoiled part (length $=220 \mathrm{~mm}$; EA $\sim 6^{\circ}$ ). The terminal aperture is not preserved. The shell ornament in the penultimate whorl consists of shallow annuli standing $1.6 \mathrm{~mm}$ apart. These annuli bear five sharp growth lines, while the interspaces between the annuli are either smooth or occupied by very delicate growth lines. The annuli weaken on the last whorl and are only barely visible at the beginning of the backcoiled part. In the middle of the backcoiled part, about $50 \mathrm{~mm}$ apart from the beginning, the shell ornament shows raised lirae in distances of $0.8-1.1 \mathrm{~mm}$; between them there are four or five delicate growth 

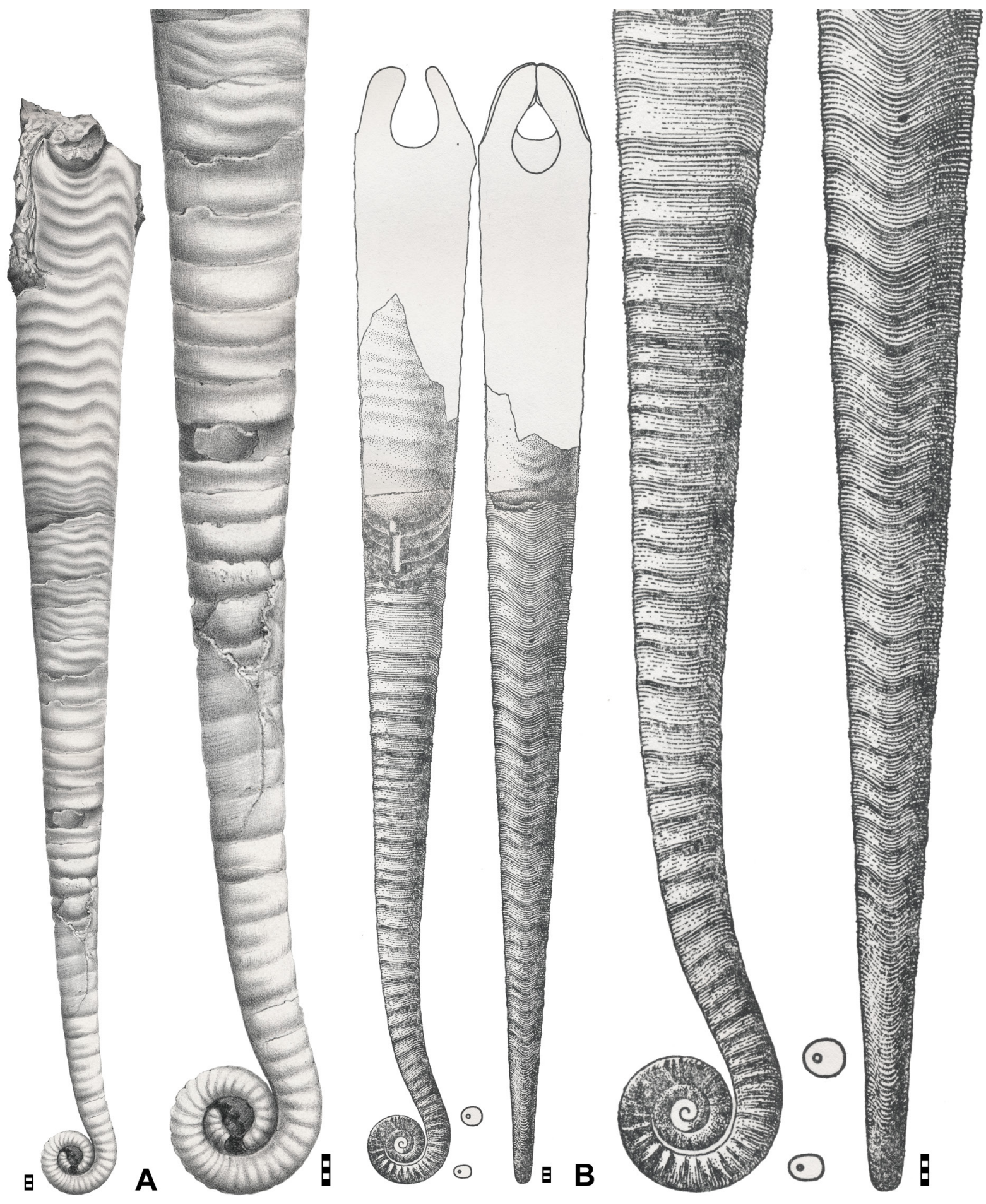

Fig. 31. Lituites lituus de Montfort, 1808; reproductions from the literature. A. Reproduction of the illustration by Noetling (1882: pl. 11 fig. 1). B. Reproduction of the illustration by Dzik (1984: pl. 41 fig. 1). Scale bar units $=1 \mathrm{~mm}$. 
lines. The lirae are imprinted on the internal mould and appear as shallow undulation. They extend with shallow ventral sinus, low and symmetric ventrolateral projection, wide and very shallow lateral sinus and low dorsal projection. In the backcoiled part of the conch, narrow annuli appear again (up to $4 \mathrm{~mm}$ apart) and are covered by lirae (up to $0.7 \mathrm{~mm}$ apart); ventral sinus is deep but rounded. The phragmocone chambers are variable in length but the CLR generally decreases towards the aperture from 0.56-0.42.

Specimens MB.C.11990 (Fig. 32) and MB.C.2497 (Fig. 33B) are rather well-preserved conchs which consist of the coiled parts (2.25-2.5 tightly coiled volutions; $\mathrm{dm}=30 \mathrm{~mm}$; Fig. 34$)$ and the moderately curved uncoiled parts (length more than $200 \mathrm{~mm}$; EA $\sim 5^{\circ}$ ). The whorl expansion rate is between 2.10 and 2.20 (Fig. 34F-O). Terminal apertures are not preserved. In specimen MB.C.2497, the coiled part has regularly spaced annuli standing $1.5 \mathrm{~mm}$ apart. Sharp growth lines occur on the annuli and also in
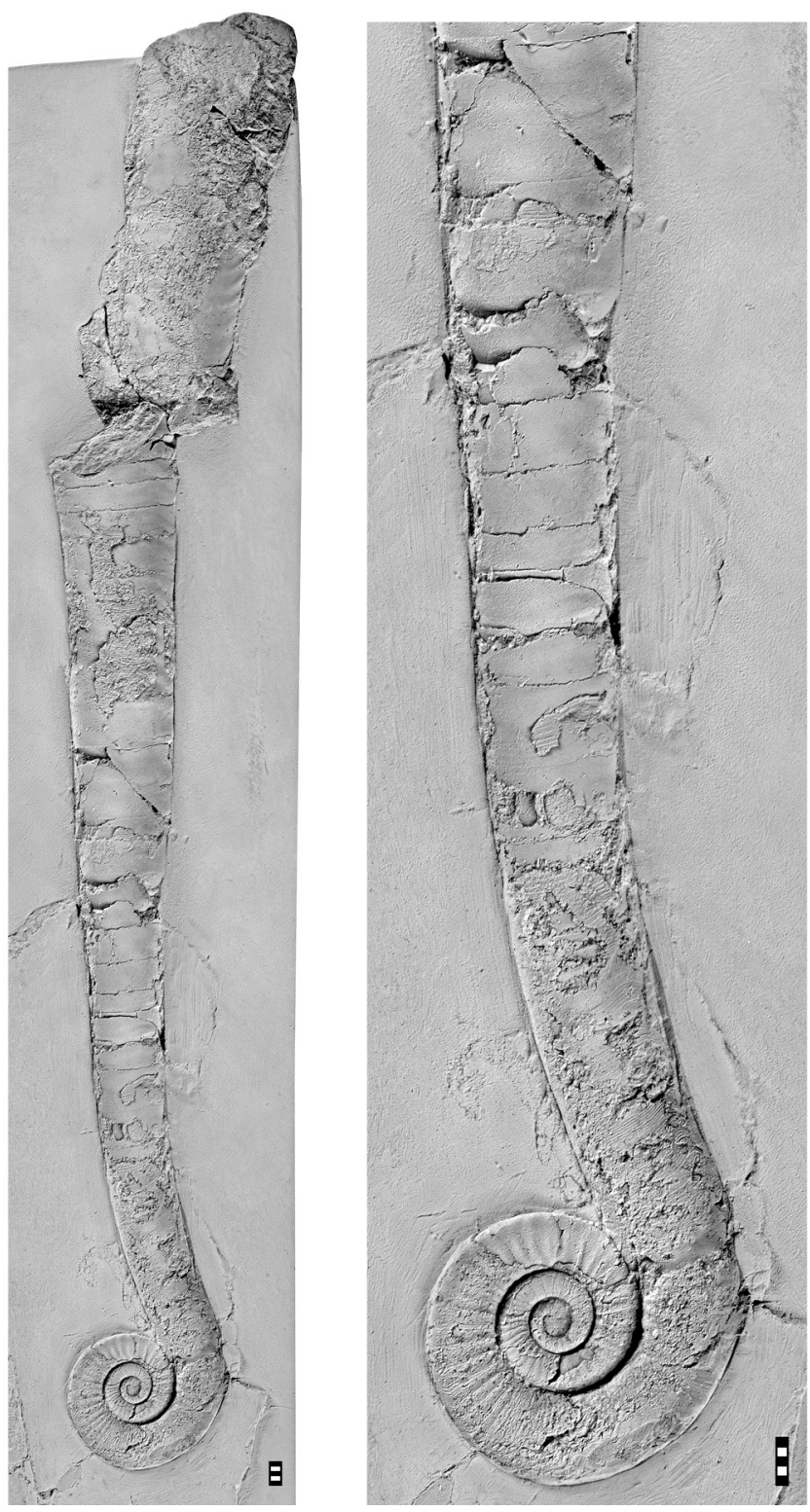

Fig. 32. Lituites lituus de Montfort, 1808 from the Upper Grey Orthoceratite Limestone; specimen MB.C.11990 (Helms 1966 Coll.) from Groß Zicker (Island of Rügen, Mecklenburg-Vorpommern). Scale bar units $=1 \mathrm{~mm}$. 
their interspaces. In contrast to the annuli, the growth lines are not imprinted on the internal mould. The backcoiled part is ornamented with irregularly spaced, rectiradiate to prorsiradiate lirae $(0.2-0.4 \mathrm{~mm}$ apart) that do not leave traces on the internal mould; strong annuli are not developed. The straight part of the conch bears lirae (up to $0.5 \mathrm{~mm}$ apart) and the internal mould bears imprints or relatively narrow annuli; ventral sinus is deep, lateral sinus is comparatively shallow. The phragmocone chambers are variable in length, both within individual specimens and between the two specimens. In specimen MB.C.11990, the chamber length ratio varies between 0.18 and 0.56 without any ontogenetic trend. Only the chambers in front of the body chamber are shorter (Fig. 35C-D). In specimen MB.C.2497, the
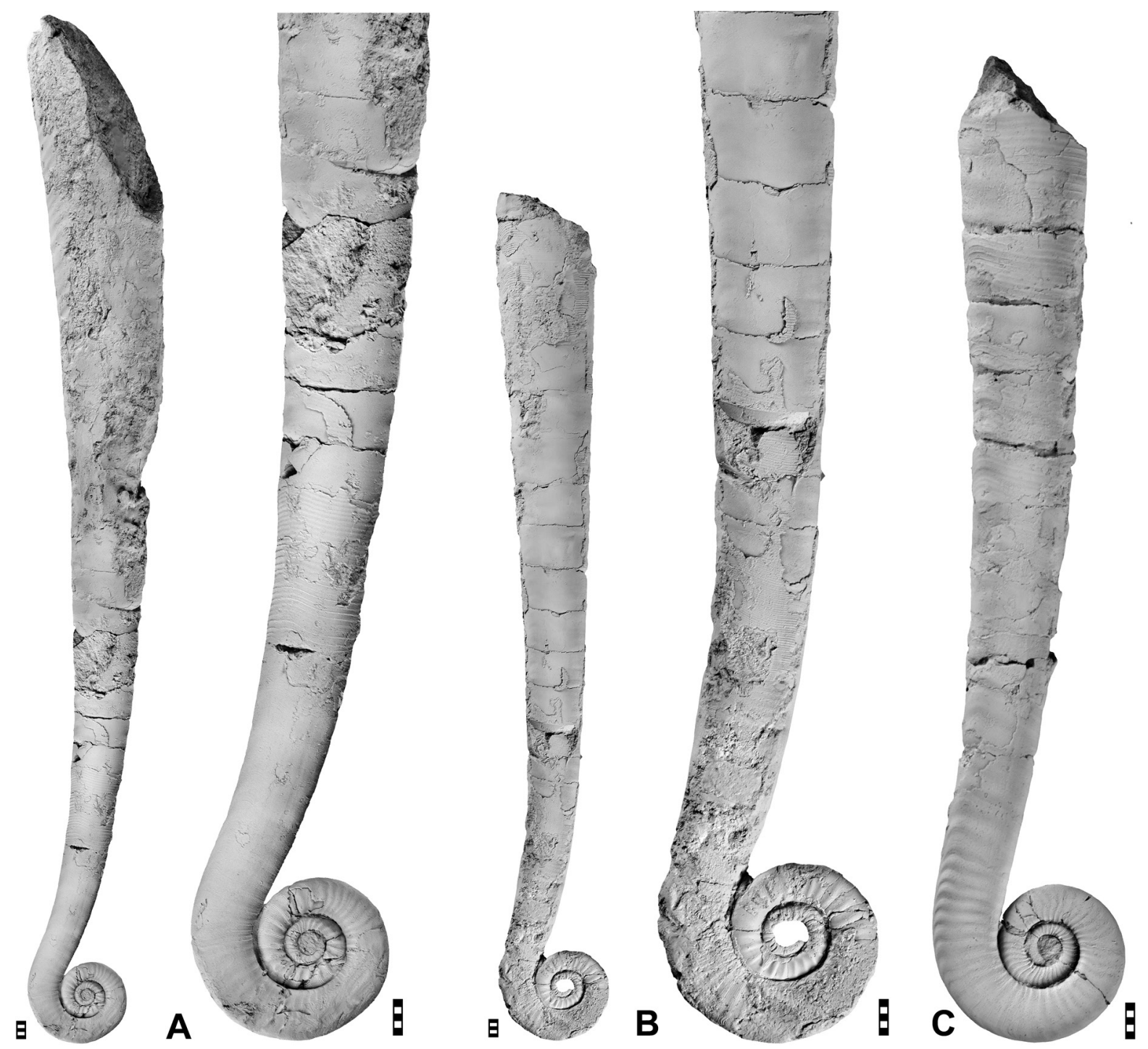

Fig. 33. Lituites lituus de Montfort, 1808 (A-B) and Lituites cf. lituus de Montfort, 1808 (C) from the Upper Grey Orthoceratite Limestone. A. Neotype MB.C.30527 (Neben \& Krueger Coll.) from Oderberg, Bralitz (Brandenburg); previously figured by Neben \& Krueger (1971: pl. 31 fig. 1); magnification of the coiled part on the right. B. Specimen MB.C.2497 (Helms 1966 Coll.) from Groß Zicker (Island of Rügen, Mecklenburg-Vorpommern); magnification of the coiled part on the right. C. Specimen MB.C.30529 (Münchner Coll.) from the Island of Chrząszczewska (former Gristow), West Pomerania, Poland. Scale bar units $=1 \mathrm{~mm}$. 

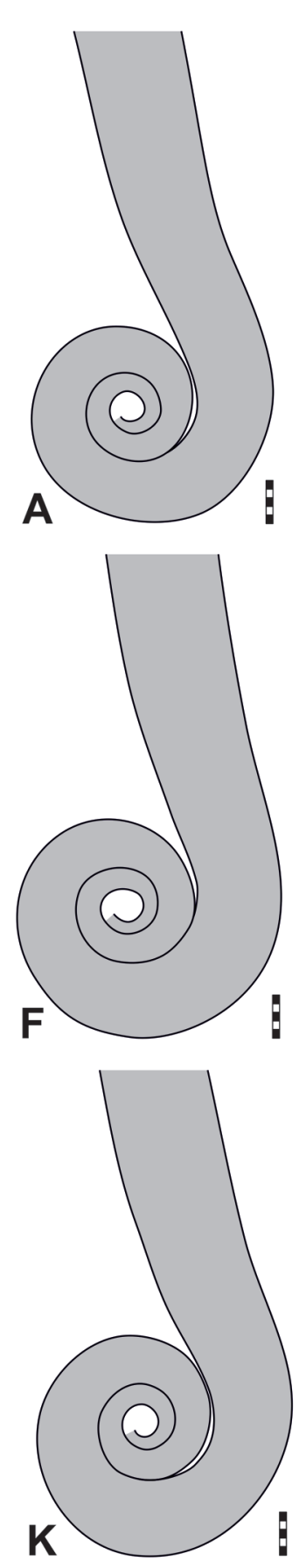
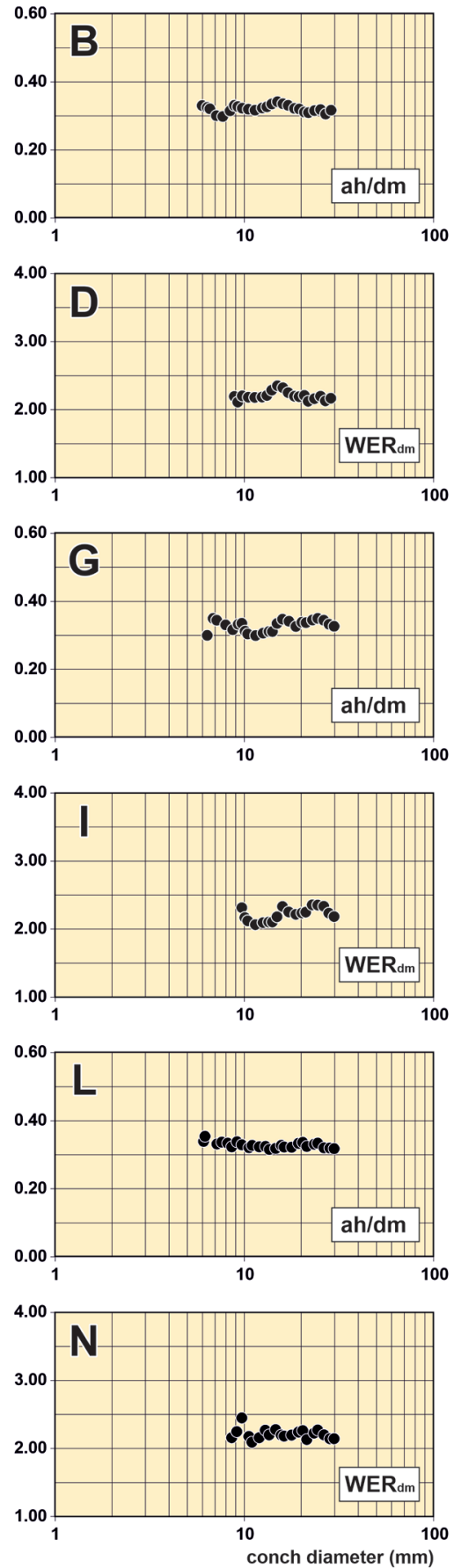
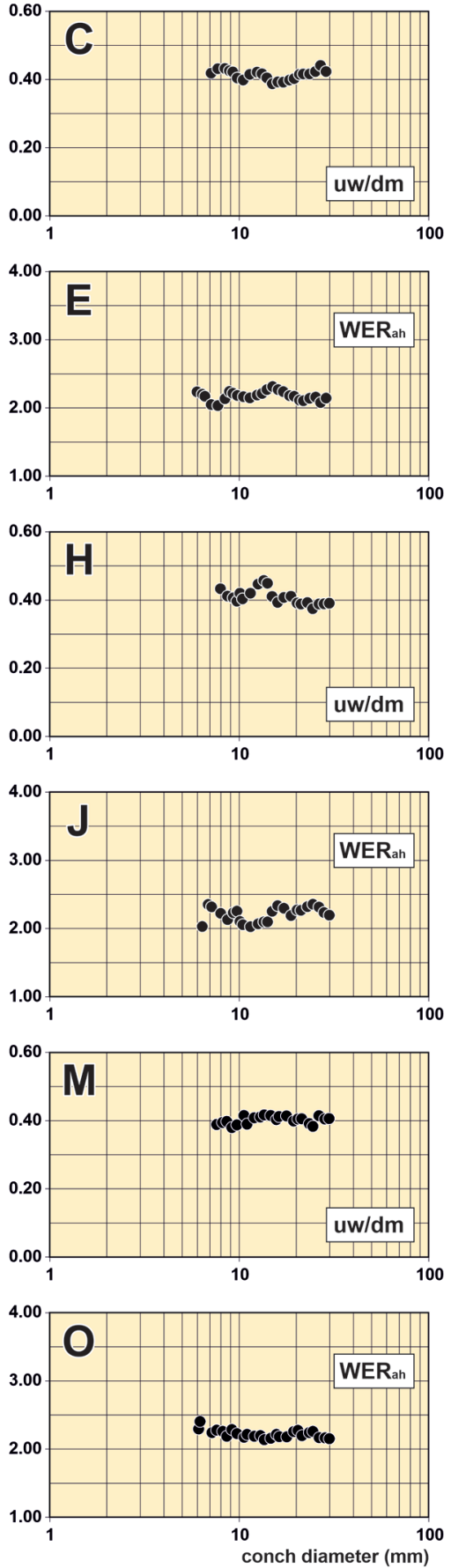

Fig. 34. Lituites lituus de Montfort, 1808. A. Outline of coiled conch part of neotype MB.C.30527. B-E. Conch proportions and coiling rates of neotype MB.C.30527. F. Outline of coiled conch part of specimen MB.C.2497. G-J. Conch proportions and coiling rates of specimen MB.C.2497. K. Outline of coiled conch part of specimen MB.C. 11990. L-O. Conch proportions and coiling rates of specimen MB.C. 11990. Scale bar units $=1 \mathrm{~mm}$. 
Table 9. Conch measurements (in mm), ratios and rates of coiled conch parts of Lituites Bertrand, 1763.

\begin{tabular}{|c|c|c|c|c|c|c|c|}
\hline $\operatorname{tax} o n$ & catalogue nr & $\mathbf{d m}$ & wh & uw & WERdm & WERah & UWI \\
\hline L. lituus & MB.C.9714 & 27.0 & 8.0 & 12.7 & - & 2.02 & 0.47 \\
\hline L. lituus & MB.C.11657 & 24.0 & 6.5 & 12.2 & 2.31 & 1.88 & 0.51 \\
\hline L. lituus & MB.C.2497 & 29.8 & 9.7 & 13.4 & 2.18 & 2.20 & 0.45 \\
\hline L. lituus & MB.C. 11990 & 29.8 & 9.5 & 13.4 & 2.13 & 2.15 & 0.45 \\
\hline L. lituus & MB.C.30527 & 28.7 & 9.1 & 13.2 & 2.17 & 2.14 & 0.46 \\
\hline L. lituus & ZPAL N/851 & 24.7 & 7.2 & 12.1 & 2.14 & 1.99 & 0.49 \\
\hline L. cf. lituus & MB.C.30529 & 27.0 & 9.0 & 11.6 & 2.25 & 2.25 & 0.43 \\
\hline L. cf. lituus & MB.C.30530 & 22.1 & 7.4 & 9.3 & 2.42 & 2.26 & 0.42 \\
\hline L. toernquisti & MB.C.30533 & 18.0 & 7.0 & 7.4 & - & 2.68 & 0.41 \\
\hline L. toernquisti & MB.C.30535 & - & 9.0 & - & - & - & - \\
\hline L. baculus & MB.C.29654 & 20.8 & 8.2 & 7.7 & 2.81 & 2.73 & 0.37 \\
\hline L. bottkei & MB.C.29651 & 25.5 & 7.6 & 12.5 & 2.20 & 2.03 & 0.49 \\
\hline L. clavis & MB.C. 30537 & 34.4 & 9.5 & 16.9 & 1.94 & 1.91 & 0.49 \\
\hline L. dewitzi & MB.C.30538 & 26.5 & 8.6 & 12.7 & 2.43 & 2.19 & 0.48 \\
\hline L. fallax & MB.C.11672.2 & 40.0 & 9.3 & - & - & 1.70 & - \\
\hline L. kruegeri & MB.C.30539 & 33.4 & 10.0 & 17.0 & 2.71 & 2.04 & 0.51 \\
\hline L. cf. kruegeri & MB.C. 30540 & 27.5 & 9.3 & 12.4 & 2.62 & 2.28 & 0.45 \\
\hline L. lasaulxii & MB.C.11678 & 28.0 & 9.5 & 11.2 & - & 2.29 & 0.40 \\
\hline L. nebeni & MB.C.30541 & 23.7 & 7.2 & 11.4 & 2.01 & 2.06 & 0.48 \\
\hline L.perfectus & MB.C.30544 & 39.0 & 10.9 & 19.5 & 2.09 & 1.93 & 0.50 \\
\hline L. perfectus & MB.C.30542 & 33.8 & 10.1 & 17.2 & 2.20 & 2.03 & 0.51 \\
\hline L. perfectus & MB.C.30545 & 32.1 & 9.0 & 16.7 & 2.05 & 1.93 & 0.52 \\
\hline L. perfectus & MB.C. 30543 & 28.9 & 9.1 & 13.6 & 2.49 & 2.13 & 0.47 \\
\hline L. perfectus & MB.C.11646 & 29.0 & 8.9 & 14.5 & 2.26 & 2.08 & 0.50 \\
\hline L. procerus & MB.C.2498 & 29.5 & 9.7 & 13.6 & 2.31 & 2.22 & 0.46 \\
\hline L. procerus & MB.C.30546 & 24.5 & 7.6 & 12.0 & 2.20 & 2.10 & 0.49 \\
\hline L. procerus & MB.C.30547 & 28.6 & 9.4 & 12.9 & 2.22 & 2.22 & 0.45 \\
\hline L. tenuicaulis & MB.C.5389 & 27.9 & 8.7 & 13.1 & 2.25 & 2.11 & 0.47 \\
\hline L. tenuicaulis & MB.C. 30550 & 29.7 & 9.8 & 13.4 & 2.23 & 2.23 & 0.45 \\
\hline L. tenuicaulis & MB.C. 30548 & 29.4 & 9.2 & 13.8 & 2.23 & 2.12 & 0.47 \\
\hline L. tenuicaulis & MB.C.30551 & 24.7 & 8.3 & - & 2.32 & 2.27 & - \\
\hline L. sp. & MB.C.9716 & 25.3 & 8.1 & - & - & - & - \\
\hline L. sp. & MB.C.29649 & 22.6 & 8.9 & 9.5 & 3.38 & 2.72 & 0.42 \\
\hline L. sp. & MB.C.11653 & 31.0 & 8.6 & 15.5 & & 1.92 & 0.50 \\
\hline L. sp. & MB.C.30570 & 28.0 & 9.3 & 12.6 & 2.75 & 2.24 & 0.45 \\
\hline L. sp. & MB.C.30572 & 28.0 & 8.9 & 13.2 & 2.17 & 2.15 & 0.47 \\
\hline L. sp. & MB.C.30576 & 20.4 & 7.2 & 9.0 & 2.39 & 2.39 & 0.44 \\
\hline L. sp. & MB.C. 29648 & 26.2 & 9.1 & 11.5 & 2.32 & 2.35 & 0.44 \\
\hline L. sp. & MB.C.30569 & 23.9 & 8.9 & 9.1 & 2.79 & 2.54 & 0.38 \\
\hline L. sp. & MB.C.30575 & 29.5 & 9.2 & - & 2.24 & 2.11 & - \\
\hline L. sp. & MB.C.30568 & 32.0 & 11.0 & - & - & 2.32 & - \\
\hline
\end{tabular}


phragmocone chambers are much longer $(\mathrm{CLR}=0.33-0.69)$ and shorter chambers are usually restricted to an earlier ontogenetic stage, while longer chambers occur later in ontogeny (Fig. 35A-B).

Specimen MB.C.11657 consists of the coiled conch $(\mathrm{dm}=24 \mathrm{~mm}$; the whorls are only very slightly detached from the preceding, detachment increases gradually and the maximum interspace width is $0.70 \mathrm{~mm}$ just before uncoiling) and the moderately curved backcoiled part of the conch (length = $100 \mathrm{~mm}$; wh $=20 \mathrm{~mm}$ ). The shell ornament of the coiled part consists of annuli and very fine growth lines (preserved only on the inner half of the last whorl). In the innermost whorl, the annuli appear only as imprints on the internal mould and are $1.3 \mathrm{~mm}$ apart. In the remaining coiled conch, the annuli are up to $1.9 \mathrm{~mm}$ apart. The lateral sinus is shallow and disappears towards the end of the coiled part. At the end of the backcoiled part and in the straight part, the ornament consists of annuli, which become wider (up to ca $7 \mathrm{~mm}$ apart) and flat; the intercalated lirae have distances of up to $0.5 \mathrm{~mm}$. Annuli as well as lirae are visible on the internal mould. The lateral sinus of the ornament elements is very shallow in the straight conch, but its depth increases during ontogeny; the dorsal projection is low and flanked by a shallow dorsolateral sinus.

\section{Remarks}

Modéer (1796) introduced the name Orthocera lituus (without referring to or depicting any specimens); some authors consequently considered Modéer (1796) the author of Lituites lituus and the type species of Lituites. Most researchers, however, regarded de Montfort (1808) as the author as he was the first to use the name Lituites lituus and is herein assumed as the author of the species name. De Montfort (1808) himself did not refer to the work of Modéer (1796).

De Montfort (1808) made only a general description of the species and did not mention or describe any particular type specimens and any type locality. The only provided illustration shows a lituiticonic conch with tightly coiled apical part and a sigmoidal backcoiled part. However, since the illustration is only an artistic representation, it cannot be determined whether it shows a particular specimen of Lituites lituus or only a general conch morphology based on multiple specimens; moreover, there are several species of the genus Lituites with tightly coiled apical part of the conch, such as L. lasaulxii.
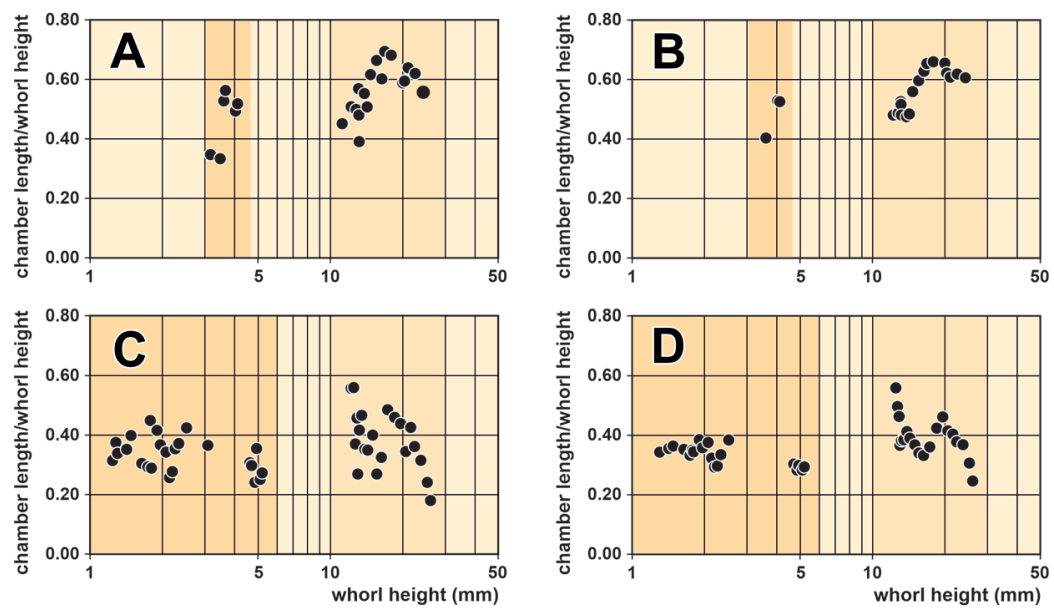

Fig. 35. Septum distances in Lituites lituus de Montfort, 1808 from the Upper Grey Orthoceratite Limestone. A, C = empirical data points; B, D = three data points averaged. A-B. Specimen MB.C.2497 (Helms 1966 Coll.) from Groß Zicker (Island of Rügen, Mecklenburg-Vorpommern). C-D. Specimen MB.C.11990 (Helms 1966 Coll.) from Groß Zicker (Island of Rügen, Mecklenburg-Vorpommern). 
Lituites lituus and L. perfectus (discussed below) were the first and for quite some time the only species assigned to Lituites. Their initial descriptions were only very general and indicated that the distinction between the two species is the tightly (L. lituus) or loosely (L. perfectus) coiled apical part of the conch. The use of the names L. lituus and L. perfectus was inconsistent during the $19^{\text {th }}$ century, when many authors developed own ideas for the species definition. Remelé (1880) attempted to draw firm lines between the two species based on the degree of coiling, the coiled conch diameter, the shape of whorl profile, the shape of the backcoiled conch part, the expansion angle and the ornament. He also defined some new species (Remelé 1880, 1890) of Lituites. Noetling (1882) and Holm (1891) stressed out the great intraspecific variation and ontogenetic changes of the characters and questioned their validity for the separation of L. lituus and L. perfectus.

Not much was added to the discussion on this particular matter during the $20^{\text {th }}$ century, but several specimens were illustrated and described (Balashov 1953; Sweet 1958; Neben \& Krueger 1971; Dzik 1984). In their study of Estonian lituitids, Aubrechtová \& Meidla (2020) synonymised Lituites lituus and L. perfectus because of transitional morphologies between the two species and a great amount of ontogenetic variation in their material. However, the presently studied collection contains more completely preserved specimens, particularly specimens from the Neben \& Krueger and the Bottke collections. The
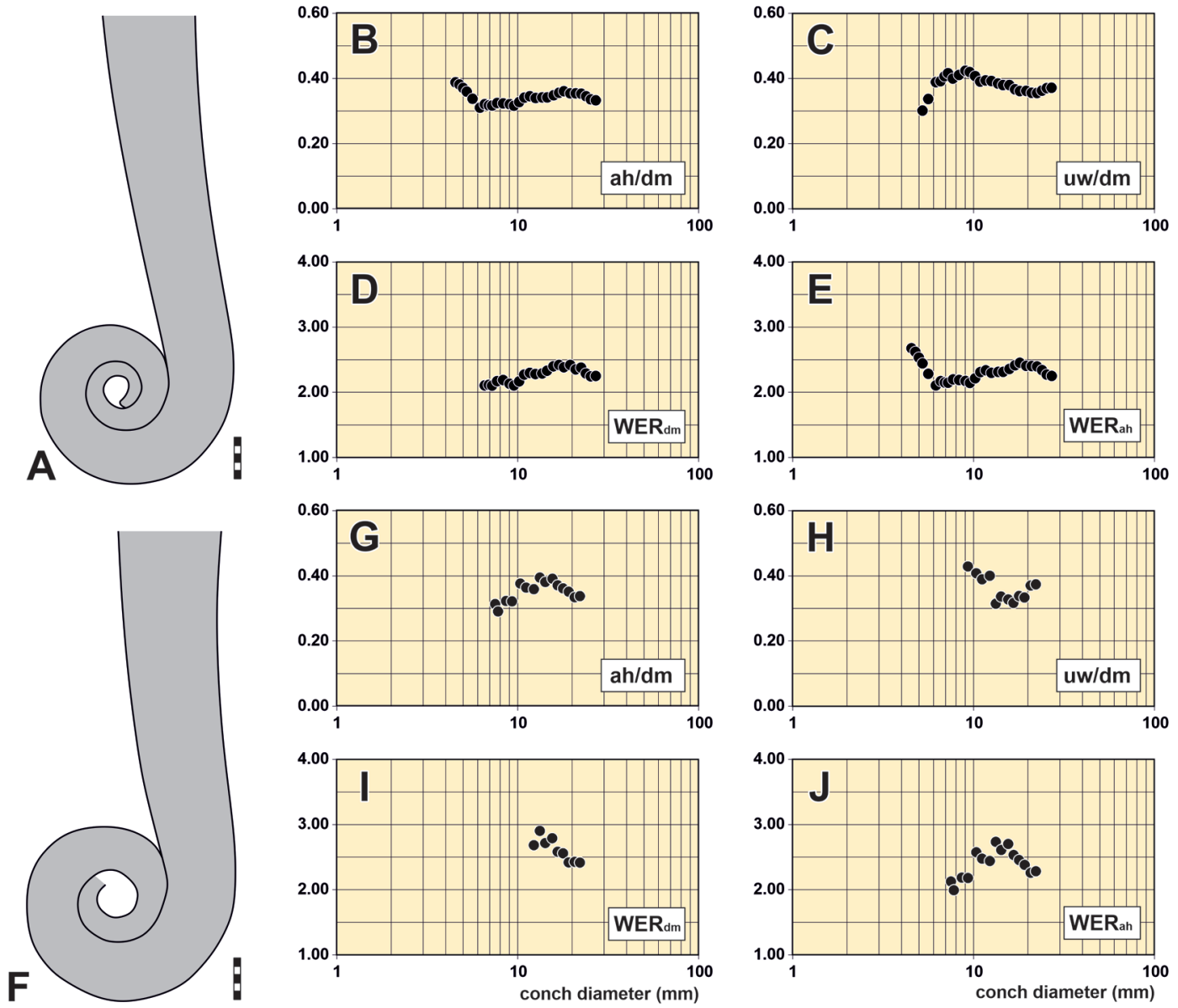

Fig. 36. Lituites cf. lituus de Montfort, 1808. A. Outline of coiled conch part of specimen MB.C.30529. B-E. Conch proportions and coiling rates of specimen MB.C.30529. F. Outline of coiled conch part of specimen MB.C.30530. G-J. Conch proportions and coiling rates of specimen MB.C.30530. Scale bar units $=1 \mathrm{~mm}$. 
study of these specimens enabled the revision of the concepts of L. lituus and L. perfectus. Since the type material of the two species is not sufficiently known, neotypes were selected for both taxa.

The neotypes were chosen based on the most reliable and detailed descriptions and illustrations in previous literature, i.e., Remelé (1880, 1890), Noetling (1882) (Fig. 31A), Holm (1891) and Dzik (1984) (Fig. 31B).

Lituites lituus differs from $L$. perfectus in having a smaller diameter of the coiled conch (up to $30 \mathrm{~mm}$ but up to $40 \mathrm{~mm}$ in L. perfectus) and tightly or almost tightly coiled volutions (openly coiled in L. perfectus); in addition, the backcoiled part of $L$. lituus is moderately to strongly curved (weakly curved or straight in $L$. perfectus), the conch has a greater expansion angle $\left(5^{\circ}-8^{\circ}\right.$ but $1^{\circ}-4^{\circ}$ in $L$. perfectus $)$ and the shell has a coarser ornament (annuli along the whole conch length).

The species most similar to L. lituus is L. lasaulxii, which has more strongly curved backcoiled part and the shell ornament lacks annuli at the coiled part of the conch and the straight part only has growth lines (not lirae) on the surface of the annuli.

Lituites procerus Remelé, 1890 also has a tightly coiled conch up to $30 \mathrm{~mm}$ in diameter as L. lituus, but its uncoiled part is only weakly curved or straight; the shell of the coiled part has ribs instead of annuli in some specimens. Lituites bottkei sp. nov. has loosely coiled volutions and a finer ornament with biconvex ornament elements in the coiled part. Lituites clavis is tightly coiled but its coiled part has a greater diameter $(34 \mathrm{~mm})$ than that in L. lituus, the backcoiled part expands rather slowly (expansion angle of $\sim 2^{\circ}$ ) and the uncoiled part is ornamented with flat (instead of prominent) annuli. The uncoiled part in L. nebeni sp. nov. is only weakly curved and very slender (almost tubular upon uncoiling) with expansion angle up to $4^{\circ}$; the shell ornament consists of flat (instead of prominent) annuli.

\section{Geographic and stratigraphic occurrence}

Norway, Sweden, Estonia (in situ) and northern Germany, northern Poland and the Kaliningrad Region (Russia) (in erratics within Pleistocene gravels); Darriwilian to early Sandbian (Middle to early Late Ordovician).

Lituites lituus is a stratigraphically significant species in Baltoscandia indicating a mid-Lasnamägian age (e.g., Jaanusson 1960; Evans et al. 2014).

Lituites cf. lituus de Montfort, 1808

Figs 33C, 36, Tables 9-10

\section{Material examined}

POLAND • 2 specs; West Pomerania, Island of Chrząszczewska (former Gristow); Ordovician, Upper Grey Orthoceratite Limestone; Müchner Coll.; MB.C.30529, MB.C.30530.

SWEDEN • 1 spec.; Island of Öland, Island of Öland; Ordovician; Technische Universität Berlin Coll.; MB.C.30531.

COUNTRY UNKNOWN・1 spec.; Ordovician; MB.C.11650.

\section{Description}

Specimen MB.C.30529 (Fig. 33C) consists of the coiled part (2.25 tightly coiled volutions; $\mathrm{dm}=27 \mathrm{~mm}$; WER 2.3; Fig. 36A-E) and the weakly curved backcoiled part (length $=102 \mathrm{~mm}$; wh $=18 \mathrm{~mm}$; EA $\sim 5^{\circ}$ ). The initial chamber of the phragmocone is cup-shaped and small (whorl height ca $1.4 \mathrm{~mm}$ ). The initial 
Table 10. Conch measurements (in $\mathrm{mm}$ ), and expansion rates of uncoiled conch parts of Lituites Bertrand, 1763.

\begin{tabular}{|c|c|c|c|c|c|c|c|}
\hline taxon & catalogue $n r$ & max. wh & max. ww & min. wh & min. ww & fragm. length & $\mathbf{E A}\left({ }^{\circ}\right)$ \\
\hline L. lituus & MB.C.2497 & 25.4 & 24.0 & 12.3 & 9.8 & 156.3 & 4.8 \\
\hline L. lituus & MB.C.11990 & 25.0 & - & 11.4 & - & 146.9 & 5.3 \\
\hline L. lituus & MB.C. 29650 & 35.8 & - & 25.8 & 24.4 & 88.0 & 6.5 \\
\hline L. lituus & MB.C.30527 & 32.0 & 32.0 & 10.5 & 9.4 & 195.3 & 6.3 \\
\hline L. lituus & MB.C.30528 & 45.0 & - & 35.0 & - & 127.2 & 4.5 \\
\hline L. lituus & ZPAL N/851 & 30.8 & - & 8.7 & - & 210.8 & 6.0 \\
\hline L. cf. lituus & MB.C.30529 & 18.3 & 18.0 & 9.8 & 8.0 & 99.3 & 4.9 \\
\hline L. cf. lituus & MB.C.30530 & 13.0 & - & 9.0 & 7.3 & 41.6 & 5.5 \\
\hline L. toernquisti & MB.C.30532 & 12.0 & - & 9.6 & 7.8 & 25.4 & 5.4 \\
\hline L. toernquisti & MB.C.30533 & 10.0 & 8.5 & 7.2 & 6.3 & 43.3 & 3.7 \\
\hline L. toernquisti & MB.C.30534 & 13.0 & - & 8.0 & - & 54.0 & 5.3 \\
\hline L. toernquisti & MB.C.30535 & 15.6 & 15.0 & 7.7 & - & 83.7 & 5.4 \\
\hline L. baculus & MB.C.29654 & 15.6 & - & 8.1 & - & 97.6 & 4.4 \\
\hline L. bottkei & MB.C.29651 & 41.9 & - & 9.7 & - & 287.9 & 6.4 \\
\hline L. bottkei & MB.C.30536 & 36.0 & - & 19.5 & - & 134.9 & 7.0 \\
\hline L. cf. bottkei & MB.T.4492.52 & 40.0 & 38.0 & 28.0 & - & 109.0 & 6.3 \\
\hline L. clavis & MB.C.30537 & 16.0 & 15.6 & 12.0 & - & 109.1 & 2.1 \\
\hline L. dewitzi & MB.C.30538 & 14.1 & - & 9.1 & - & 60.9 & 4.7 \\
\hline L. kruegeri & MB.C.30539 & 11.0 & 10.4 & 10.8 & 9.3 & 12.7 & 0.9 \\
\hline L. lasaulxii & MB.C. 11678 & 18.4 & - & 10.4 & - & 81.8 & 5.6 \\
\hline L. lasaulxii & MB.C.11645 & 16.2 & - & 10.0 & - & 64.5 & 5.5 \\
\hline L. cf. lasaulxii & MB.C.11677 & 24.0 & - & 19.0 & - & 75.4 & 3.8 \\
\hline L. nebeni & MB.C.30541 & 12.7 & 12.3 & 8.6 & 7.3 & 61.8 & 3.8 \\
\hline L. perfectus & MB.C.30544 & 11.4 & 10.2 & 11.3 & 9.7 & 10.0 & 0.8 \\
\hline L. perfectus & MB.C.30542 & & 11.0 & 10.3 & 9.0 & 229.2 & 0.5 \\
\hline L. perfectus & MB.C.30543 & 15.2 & 13.7 & 10.9 & 9.6 & 82.1 & 3.0 \\
\hline L. procerus & MB.C.2498 & 9.8 & - & 9.7 & - & 19.1 & 0.3 \\
\hline L. procerus & MB.C.30546 & 10.0 & 9.0 & 8.7 & - & 49.6 & 1.5 \\
\hline L. procerus & MB.C. 30547 & 12.8 & - & 10.6 & - & 25.7 & 4.9 \\
\hline L. tenuicaulis & MB.C.5389 & 12.4 & - & 10.3 & - & 44.5 & 2.7 \\
\hline L. tenuicaulis & MB.C.30550 & 11.7 & - & 10.2 & - & 34.4 & 2.5 \\
\hline L. sp. & MB.C.11673.2 & 19.2 & 19.0 & 14.0 & - & 59.5 & 5.0 \\
\hline L. sp. & MB.C.29649 & 20.7 & - & 10.1 & - & 77.7 & 7.8 \\
\hline L. sp. & MB.C. 11628 & 47.4 & - & 22.7 & 22.2 & 204.8 & 6.9 \\
\hline L. sp. & MB.C.11653 & 11.1 & - & 10.1 & - & 28.6 & 2.0 \\
\hline L. sp. & MB.C.30572 & 11.9 & - & 9.7 & - & 42.0 & 3.0 \\
\hline L. sp. & MB.C.30576 & 11.8 & 11.0 & 9.1 & 7.4 & 44.2 & 3.5 \\
\hline L. sp. & MB.C.29648 & 16.6 & - & 10.0 & - & 63.0 & 6.0 \\
\hline L. sp. & MB.C.30569 & 21.4 & 21.4 & 10.6 & 9.2 & 103.0 & 6.0 \\
\hline L. sp. & MB.C.9706 & 37.0 & - & 29.0 & - & 86.4 & 5.3 \\
\hline L. sp. & MB.C.30575 & 12.4 & 12.0 & 10.0 & 8.3 & 43.0 & 3.2 \\
\hline L. sp. & MB.C.30568 & 19.0 & - & 12.7 & 11.0 & 52.2 & 6.9 \\
\hline
\end{tabular}


ca $4 \mathrm{~mm}$ of conch length is ornamented by fine growth lines $(0.1-0.2 \mathrm{~mm}$ apart); after that pairs of raised lirae appear (up to $0.7 \mathrm{~mm}$ apart) with extremely fine growth lines in between them. From about the beginning of the second whorl, a weak lateral sinus is developed. The ornament of the rest of the coiled and backcoiled part of the conch consists of biconvex lirae and flat ribs. The ribs are barely discernible in the second half of the specimen and only coarse lirae are visible (1.3 $\mathrm{mm}$ apart). Lateral sinus is either very shallow or the ornament elements are straight, ventral sinus is deep and rounded, dorsal projection and dorsolateral sinuses are not developed. At the end of the specimen, only lirae (1 mm apart) are present.

\section{Remarks}

The specimens resemble Lituites lituus in their overall dimensions, but the backcoiled part in specimens MB.C.30529, MB.C.30530 (Fig. 36F-J) and MB.C.30531 is only weakly curved and the shell ornament is slightly finer. Specimen MB.C.30529 differs with its biconvex lirae and flat ribs on the shell surface. Specimen MB.C.11650 is a fragmentary and slightly deformed body chamber, which has a finer shell ornament; the ornament elements form a flatter lateral sinus compared to L. lituus.

Lituites perfectus Wahlenberg, 1818

Figs 37-42, Tables 9-11

Lituites perfectus Wahlenberg, 1818: 83.

Lituites perfectus - Remelé 1880: pl. 1 fig. 2; 1890: pl. 1 fig. 2, pl. 6 fig. 3. - Holm 1891: 12, pl. 2 figs 1-5. - Hardt 1953: 45, text-fig. 10.

Lituites lituus? - Aubrechtová \& Meidla 2020: 286, text-fig. 141.

? Lituites perfectus - Balashov 1953: pl. 14 fig. 4. - Sweet 1958: 144, pl. 16 fig. 4.

\section{Diagnosis}

Species of the genus Lituites with coiled part ca $29-40 \mathrm{~mm}$ in diameter; coiling open, eccentric, only innermost whorls contiguous, end part of the last whorl might be in the proximity or in contact with preceding whorl; whorl expansion rate ca 2.00. Backcoiled part of the conch weakly curved, expansion angle ca $1^{\circ}$, later up to $4^{\circ}$. Shell ornament with growth lines and annuli or ribs; rectiradiate in the coiled part and prorsiradiate in the backcoiled part. Ventral sinus deep with a ventral band, shallow lateral sinus just in front of the moderately high ventrolateral projection.

\section{Type material}

\section{Neotype}

GERMANY • Mecklenburg-Vorpommern, Lansen (Malchin); Ordovician (late Lasnamägi or Uhaku regional stages, late Darriwilian), Upper Grey Orthoceratite Limestone; Krueger Coll.; MB.C.30544 (illustrated in Fig. 38A).

\section{Additional material}

GERMANY - 2 specs; Brandenburg, Eberswalde; Ordovician, Upper Grey Orthoceratite Limestone; Kgl. Forstakademie Eberswalde Coll.; MB.C.11622, MB.C.11646 • 1 spec.; Brandenburg, Niederfinow; Ordovician, Upper Grey Orthoceratite Limestone; Neben Coll.; MB.C.30542 • 1 spec.; Brandenburg, Oderberg (Bralitz); Ordovician, Upper Grey Orthoceratite Limestone; Krueger Coll.; MB.C.30543.

POLAND • 1 spec.; Kujawi-Pomerania, Bydgoszcz (former Bromberg); Ordovician, Upper Grey Orthoceratite Limestone; MB.C.30545. 


\section{Description}

Neotype MB.C.30544 (Fig. 38A) consists of the coiled part $(\mathrm{dm}=39 \mathrm{~mm}, 2.5$ openly, eccentrically coiled volutions not touching each other, Fig. 39A-E) and a short part of the backcoiled part (length = $32 \mathrm{~mm}$; wh $=11.4 \mathrm{~mm} ; \mathrm{EA}<1^{\circ}$ ). The shell ornament is best preserved at the transition of the coiled part to the backcoiled part of the conch. Here, it consists of narrow annuli (1.8-2.4 mm apart) and delicate growth lines (up to $0.2 \mathrm{~mm}$ apart). They extend with a broad and shallow lateral sinus across the flanks and then turn forward for a moderately high ventrolateral projection. On the venter they form a deep sinus. The close approximation of the growth lines leads to the formation of a ventral band (Fig. 42). The dorsal projection is very low. The ornament elements are concavo-convex and change from rectiradiate to prorsiradiate towards the backcoiled part of the conch. The phragmocone chambers are 0.60 of whorl height.

Specimen MB.C.30542 (Figs 38B, 39F-J) consists of a coiled and uncoiled part of the conch and has essentially the same dimensions as the neotype. The shell ornament, however, differs as it possesses much coarser growth lines that stand in distances of $0.3-0.6 \mathrm{~mm}$ at the beginning of the backcoiled part. In the coiled part, at $18 \mathrm{~mm}$ diameter, there are sharp annuli standing about $1.2 \mathrm{~mm}$ apart (mid-flank area); they weaken out in the outer flank area. Sharp growth lines (irregularly spaced 0.05-0.2 mm) occur between and on the crests of the annuli. In the backcoiled part, the shell wall is mostly not preserved; ornament is visible only as imprints of narrow annuli. The ornament elements extend straight across the flank with a very shallow sinus close to the ventrolateral projection. The CLR is $\sim 0.57$, with an increasing trend during ontogeny; however, a rapid decrease in the CLR followed by a rapid increase occurs at the end of the coiled part (Fig. 41A-B).

Specimen MB.C.11646 (Figs 37B, 38C) is a coiled part of a conch with $29 \mathrm{~mm}$ diameter; only a very short portion of the uncoiled part preserved. The volutions are slightly more regularly coiled compared to the other specimens (Fig. 39K-O). The CLR is ca 0.38 with a general decreasing ontogenetic trend up to the end of the coiled part, where the CLR starts to increase (Fig. 41E-F). In specimen MB.C.30543, the CLR also appears to be relatively higher, where the conch uncoiling starts (Fig. 41C-D).

\section{Remarks}

The name Lituites perfectus was introduced by Wahlenberg (1818); the original work was then republished later (Wahlenberg 1821); this caused some later authors to erroneously use the latter year of the species description. Wahlenberg (1818) did not describe or illustrate any type material and only referred to a

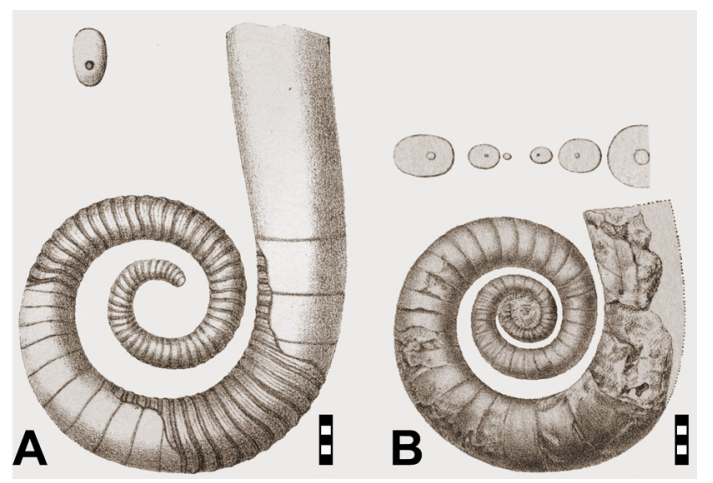

Fig. 37. Lituites perfectus Wahlenberg, 1818; reproductions of illustrations of Remelé (1890). A. Specimen MB.C.11622 from Eberswalde (Brandenburg), illustrated by Remelé (1890: pl. 1 fig. 2). B. Specimen MB.C.11646 from Eberswalde (Brandenburg), illustrated by Remelé (1890: pl. 6 fig. 3). 
specimen depicted previously by Walch (1771: pl. 4 fig. 1) as "the best example" of L. perfectus. Later, Holm (1891) reviewed the species and identified two probable originals of Wahlenberg (1818) in the collections of the Uppsala University, Sweden. However, Holm (1891) concluded that both specimens are too poorly preserved to be determined and might even represent two different species. He also pointed out that the specimen figured by Walch (1771) contradicts the brief description of Wahlenberg (1818) because its apical part is loosely, not tightly coiled. Despite that, Holm (1891) and other authors regarded the specimen of Walch (1771) as the type of Lituites perfectus.

The illustration of the specimen of Walch (1771: pl. 4 fig. 1) is a drawing, which shows a section through a lituiticonic conch with loosely coiled apical portion and a slightly curved, almost tubular uncoiled portion. Based on this illustration, it is not possible to determine the species identity of the specimen because the shell ornament is not shown and the above combination of characters is present in several lituitid species, such as Lituites nebeni sp. nov., Trilacinoceras discors or T. filix sp. nov.

The ambiguous interpretation of Lituites perfectus led to an inconsistent use of the name and specimens with variable conch shapes were thus assigned to the species. Lituites perfectus was most commonly confused with $L$. lituus. The herein studied material enabled the recovery and re-definition of $L$. perfectus and selection of a neotype. For further discussion, see remarks under L. lituus above.

Lituites perfectus differs from $L$. lituus in the larger diameter of the coiled conch, openly coiled volutions (tightly or almost tightly coiled in L. lituus), in the backcoiled part being weakly curved or straight (moderately to strongly curved in L. lituus), in the lower expansion angle of the conch (less than $1^{\circ}-4^{\circ}$ but $5^{\circ}-8^{\circ}$ in L. lituus) and in the generally finer ornament of the shell (L. lituus has annuli along the whole conch length).
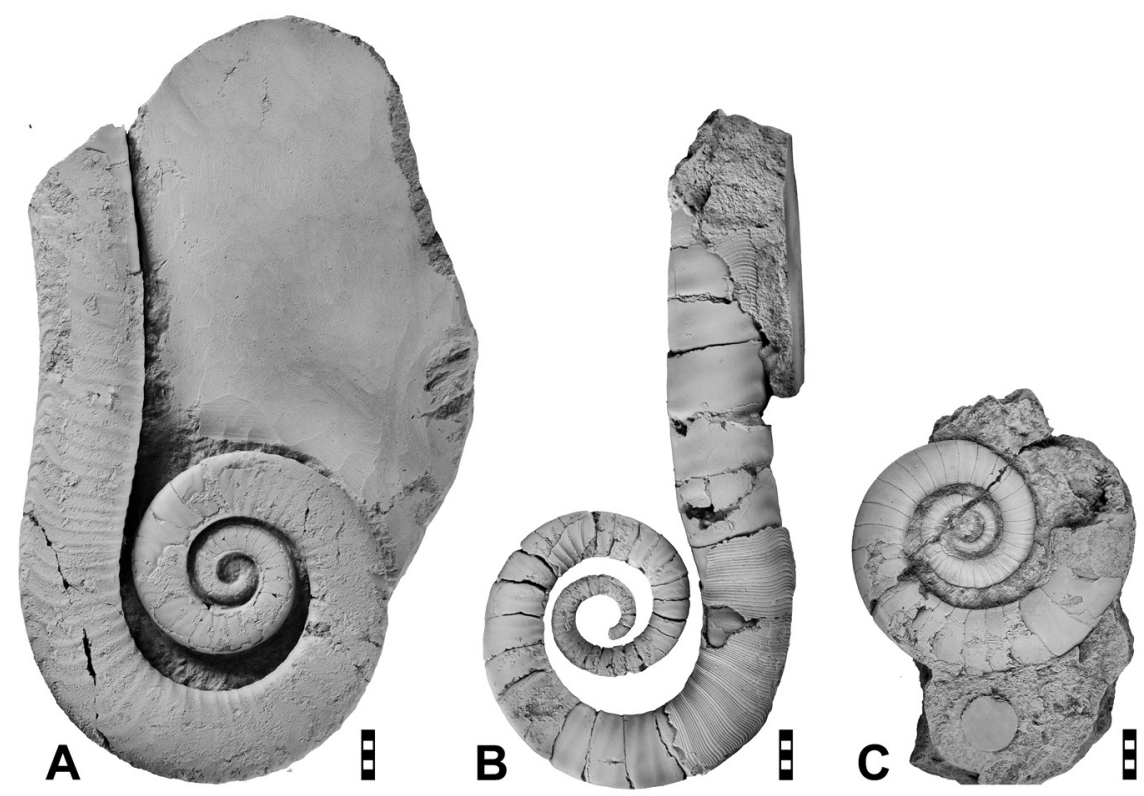

Fig. 38. Lituites perfectus Wahlenberg, 1818 from the Upper Grey Orthoceratite Limestone. A. Neotype MB.C.30544 (Krueger Coll.) from Lansen near Malchin (Mecklenburg-Vorpommern, Germany). B. Specimen MB.C.30542 (Neben Coll.) from Niederfinow (Brandenburg). C. Specimen MB.C.11646 (Kgl. Forstakademie Eberswalde Coll.) from Eberswalde (Brandenburg). Scale bar units $=1 \mathrm{~mm}$. 

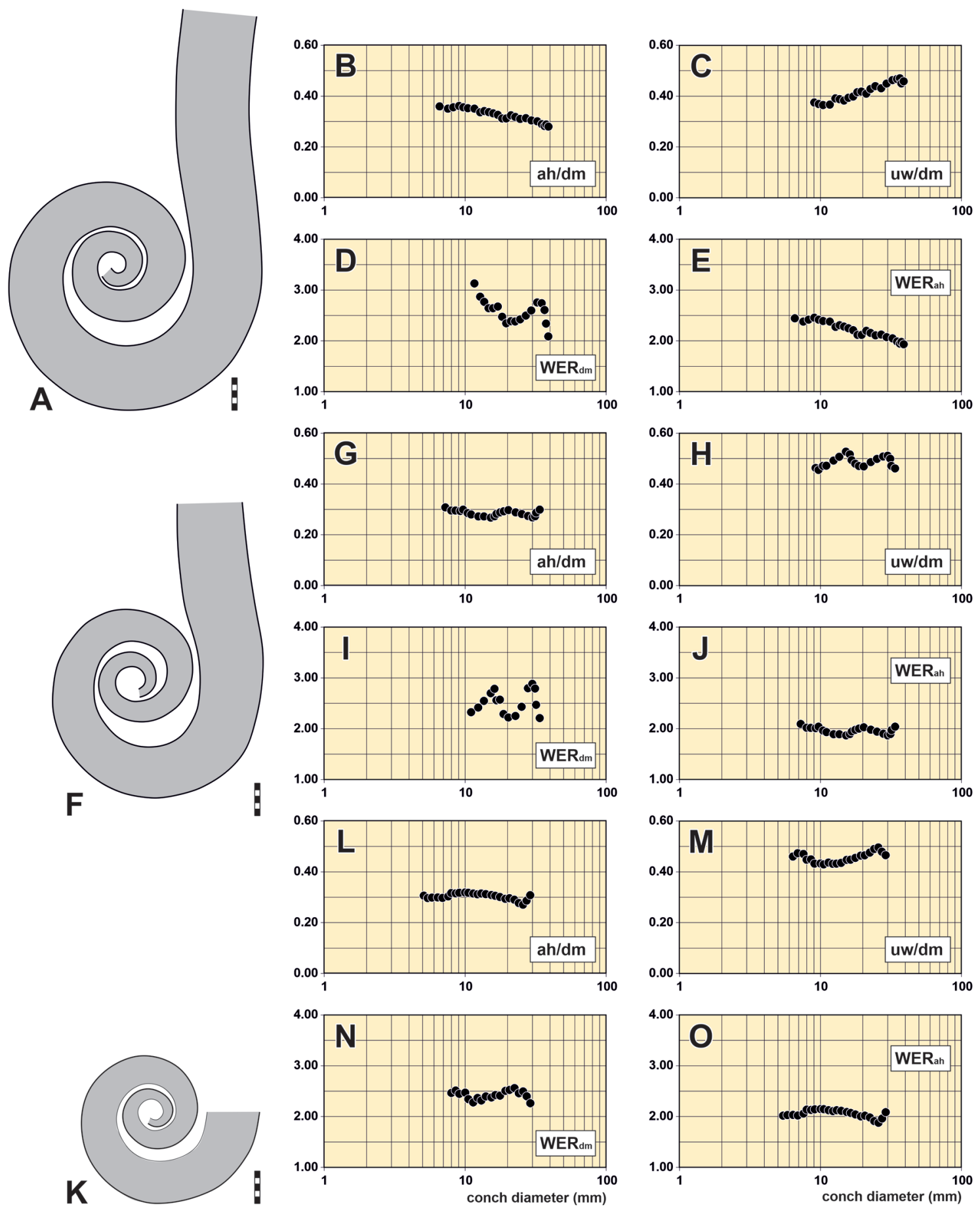

Fig. 39. Lituites perfectus Wahlenberg, 1818. A. Outline of coiled conch part of neotype MB.C.30544. B-E. Conch proportions and coiling rates of neotype MB.C.30544. F. Outline of coiled conch part of specimen MB.C.30542. G-J. Conch proportions and coiling rates of specimen MB.C.30542. K. Outline of coiled conch part of specimen MB.C.11646. L-O. Conch proportions and coiling rates of specimen MB.C.11646. Scale bar units $=1 \mathrm{~mm}$. 
Table 11. Siphuncular diameter ratio (SDR) and siphuncular distance ratio (SPR) at their corresponding whorl height in specimens of Lituites Bertrand, 1763.

\begin{tabular}{llcccc}
\hline taxon & catalogue $\mathbf{~ r r}$ & wh & SDR & wh & SPR \\
\hline L. baculus & MB.C.29654 & 16.0 & 0.16 & 16.0 & 0.46 \\
L. kruegeri & MB.C.30539 & 11.0 & 0.18 & 11.0 & 0.35 \\
L. lasaulxii & MB.C.11678 & 18.4 & 0.11 & - & - \\
L. perfectus & MB.C.30543 & 15.2 & 0.16 & 15.2 & 0.29 \\
L. tenuicaulis & MB.C.5389 & 12.5 & 0.18 & 12.5 & 0.32 \\
L. sp. & MB.C.11628 & 22.7 & 0.13 & 22.7 & 0.34 \\
L. sp. & MB.C.30576 & - & - & 11.8 & 0.30 \\
L. sp. & MB.C.29648 & 10.0 & 0.16 & - & - \\
\hline
\end{tabular}
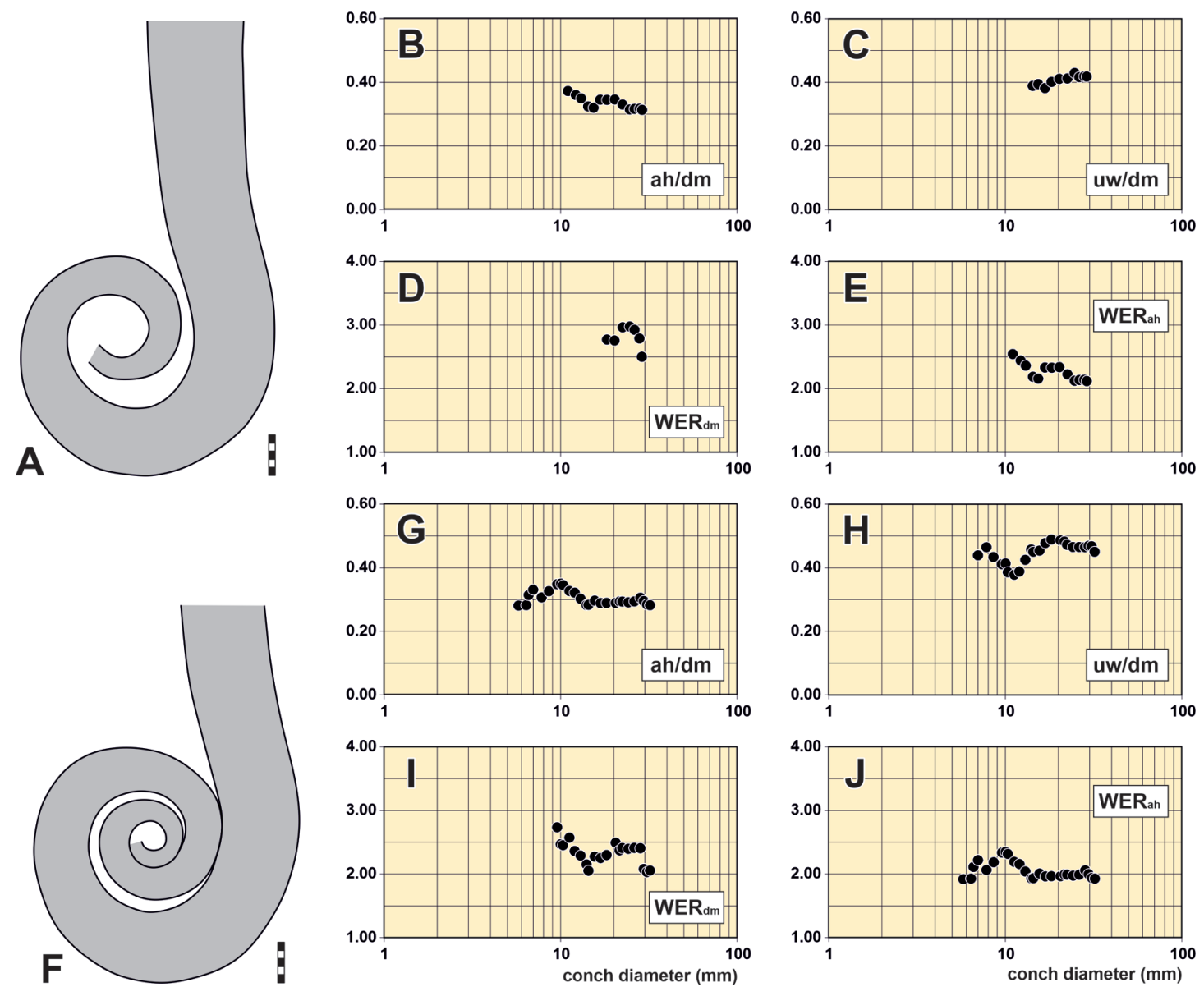

Fig. 40. Lituites perfectus Wahlenberg, 1818. A. Outline of coiled conch part of specimen MB.C.30543. B-E. Conch proportions and coiling rates of specimen MB.C.30543. F. Outline of coiled conch part of specimen MB.C.30545. G-J. Conch proportions and coiling rates of specimen MB.C.30545. Scale bar units $=1 \mathrm{~mm}$. 
The species most similar to L. perfectus is $L$. kruegeri sp. nov.; the coiled part of both species is relatively large (more than $30 \mathrm{~mm}$ in diameter), the volutions are openly coiled and the uncoiled part is almost straight with a low expansion angle $\left(\sim 1^{\circ}\right)$. However, L. perfectus, has a less regular (eccentric) coiling geometry and a more prominent shell ornament compared to L. kruegeri sp. nov.

Lituites bottkei sp. nov. is openly coiled but its conch diameter is smaller (26 mm) compared to $L$. perfectus, the coiling is regular (not eccentric) and the uncoiled part is moderately curved with a greater expansion angle $\left(6^{\circ}-7^{\circ}\right.$ vs $1-3^{\circ}$ in $L$. perfectus). In $L$. dewitzi sp. nov., only the last half whorl is detached from the preceding (inner volutions are tightly coiled), the coiled part diameter is smaller $(27 \mathrm{~mm})$ than in L. perfectus, the uncoiled part has an expansion angle of $5^{\circ}$ and the general character of ornament is different (especially in the prorsiradiate direction of ornament elements in the coiled part of the conch).

The variation in L. perfectus concerns mainly the conch diameter and the degree of eccentricity of coiling (Figs 39-40).
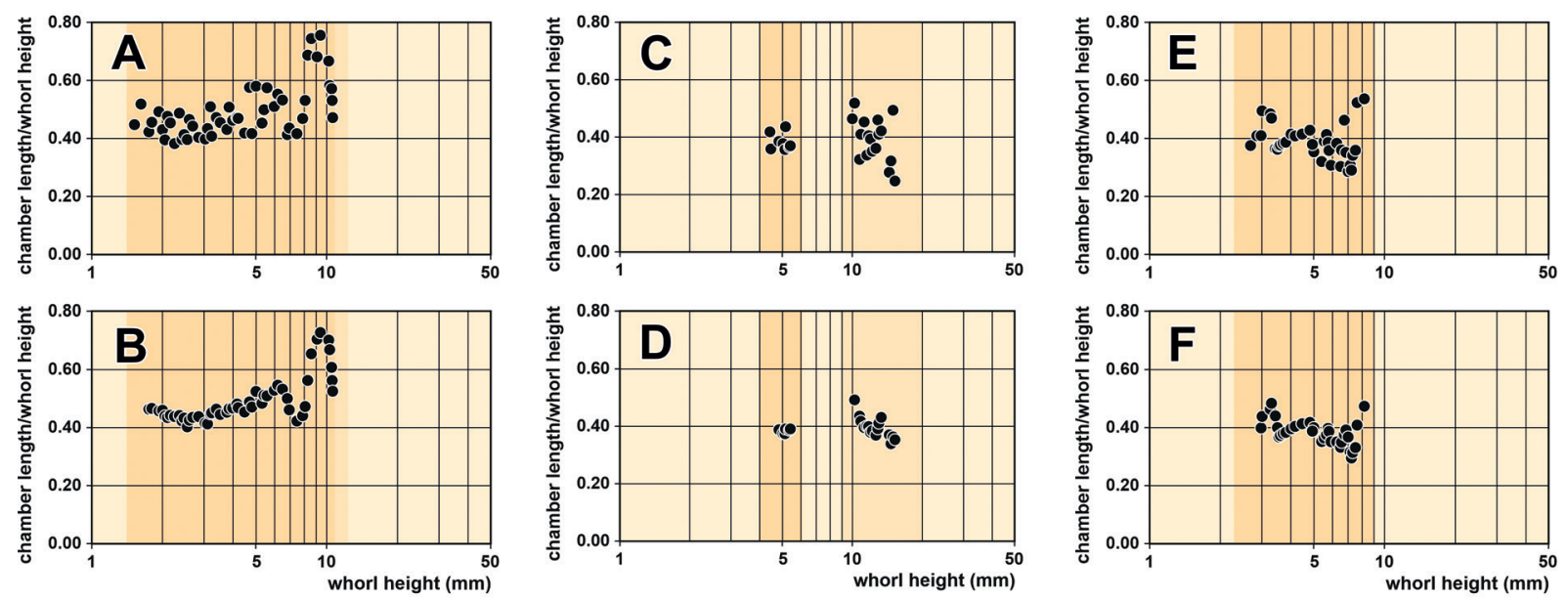

Fig. 41. Septum distances in Lituites perfectus Wahlenberg, 1818 from the Upper Grey Orthoceratite Limestone. Upper row $=$ empirical data points; lower row $=$ three data points averaged. A-B. Specimen MB.C.30542 (Neben Coll.) from Niederfinow (Brandenburg). C-D. Specimen MB.C.30543 (Krueger Coll.) from Oderberg (Bralitz) (Brandenburg). E-F. Specimen MB.C.11646 (Kgl. Forstakademie Eberswalde Coll.) from Eberswalde (Brandenburg).

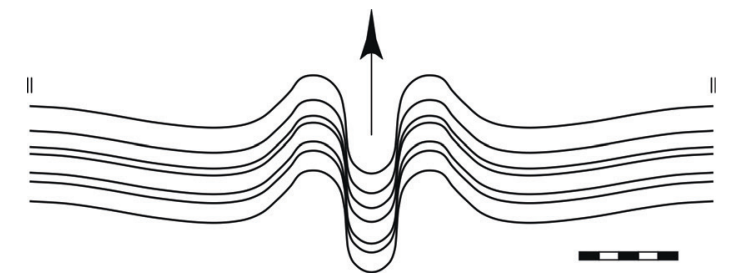

Fig. 42. Lituites perfectus Wahlenberg, 1818 from the Upper Grey Orthoceratite Limestone; lirae in the neotype MB.C.30544 (Neben Coll.) from Niederfinow (Brandenburg), at wh $=11 \mathrm{~mm}$. Scale bar units = $1 \mathrm{~mm}$. 
The illustration of specimen MB.C.11622 in Remelé (1890: pl. 1 fig. 2; reproduced here in Fig. 37A) is an idealised reconstruction of a rather poorly preserved, fragmentary specimen. Re-study of the specimen revealed, however, that the diagnostic characters of L. perfectus are present and the assignment to this species is plausible.

\section{Geographic and stratigraphic occurrence}

Norway (?), Sweden (?), Estonia (in situ) and northern Germany and northern Poland (in erratics within Pleistocene gravels); late Darriwilian, Middle Ordovician.

Lituites perfectus is a stratigraphically significant species in Baltoscandia indicating the late Lasnamägian age (e.g., Jaanusson 1960; Evans et al. 2014).

Lituites toernquisti Holm, 1891

Figs 43-44, Tables 9-10

Lituites Törnquisti Holm, 1891: 9, pl. 1 figs 1-4.

Lituites törnquisti - Sweet 1958: 124, 147.

? Lituites lituus - Hucke 1967: 56, pl. 17 fig. 5.

Lituites sp. - Neben \& Krueger 1971: pl. 21 fig. 7.

Lituites toernguisti - Chen 1987: 77.

non Lituites tornquisti - Jaanusson \& Mutvei 1953: text-fig. 3a.

non Lituites törnquisti - Neben \& Krueger 1971: pl. 21 fig. 8.

\section{Diagnosis}

Species of the genus Lituites with coiled conch diameter of 16-20 mm; whorls contiguous but not in contact. Uncoiled part moderately curved, expansion angle of $3-5.5^{\circ}$ in early growth stages and $7^{\circ}$ in later growth stages; whorl height at maturity of ca $25 \mathrm{~mm}$. Mature aperture with broad lateral sinuses and a deep ventral sinus; dorsolateral lappets not indicated by the shape of ornament elements (after Holm 1891 and Sweet 1958).

\section{Type material}

Not available for study; Holm (1891: pl. 1 figs 1-4) illustrated one specimen (reproduced here in Fig. 43A), it is from Sollerön (Dalarna, Sweden), Red Lituites Limestone (Lituites tornquisti Zone, Segerstad Limestone, upper part of the Upper Red Orthoceratite Limestone, Aseri Regional Stage, middle Darriwilian, Middle Ordovician).

\section{Material examined}

GERMANY - 1 spec.; Brandenburg, Niederfinow; Ordovician, Upper Red Orthoceratite Limestone; Neben Coll.; MB.C.30532 • 3 specs; Brandenburg, Niederfinow; Ordovician, Upper Red Orthoceratite Limestone; Neben and Krueger Coll.; MB.C.30533 to MB.C.30535.

\section{Description}

Specimen MB.C.30533 (Fig. 43C) is a fragment of a coiled part (last half of a coiled volution preserved) and a short part of the moderately curved backcoiled part (length $=20 \mathrm{~mm}$; wh $=12.4 \mathrm{~mm}$; EA $\sim 4^{\circ}$ ) of a conch with a compressed whorl profile (WWI $=0.85$ ). The shell surface is weathered but coarse annuli are well-discernible even in the coiled part of the conch; just behind the coiled part of the conch, fine lirae or growth lines are preserved between the annuli. 
Additional information about the ornament is provided by the specimens MB.C.30532 (Fig. 43B) and MB.C.30534 (Fig. 44), which have coarse, prorsiradiate annuli and lirae; the elements form a relatively deep and sharp ventral sinus, while the lateral sinus and dorsal projection are not developed.

\section{Remarks}

Specimen MB.C.30533 corresponds to the species description given by Holm (1891) in the very small dimensions, the low expansion angle of the backcoiled part and a relatively coarse ornament. The other three specimens differ in larger expansion angles (5.3 $3^{\circ}$ in MB.C.30534, and 5.4 ${ }^{\circ}$ in MB.C.30532 and MB.C.30535), but they are also assigned to L. toernquisti here, since they correspond to specimen MB.C.30533 both in size and ornament.

On the contrary, specimen MB.C.30568 (Neben \& Krueger 1971: pl. 21 fig. 8) and also the specimen figured by Jaanusson \& Mutvei (1953: text-fig. 3a) are not included in L. toernquisti here because they
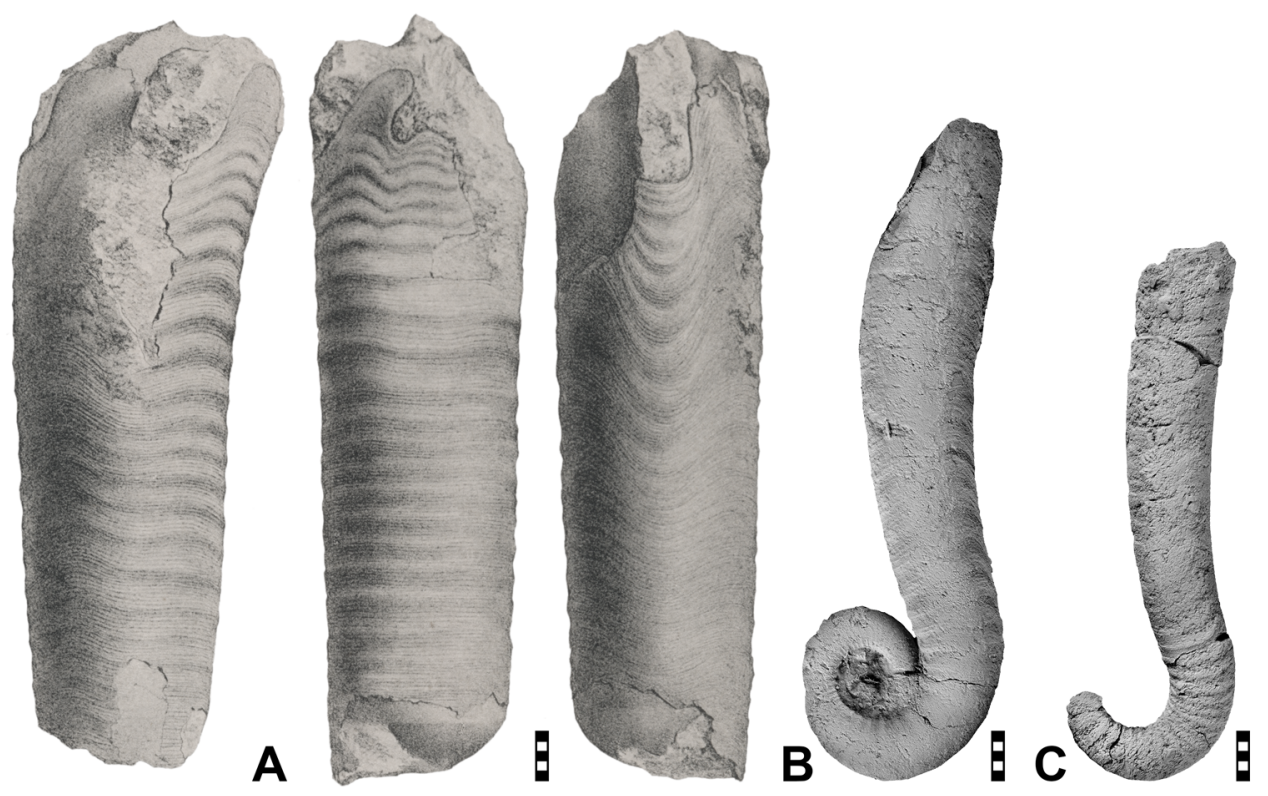

Fig. 43. Lituites toernquisti Holm, 1891 from the Upper Grey Orthoceratite Limestone. A. Reproduction of the illustration by Holm (1891: pl. 1 figs 1-3); from left to right - lateral, dorsal and ventral view of specimen (mature aperture). B. Specimen MB.C.30532 (Neben Coll.) from Niederfinow (Brandenburg); previously figured by Neben \& Krueger (1971: pl. 21 fig. 7); lateral view of specimen. C. Specimen MB.C.30533 (Neben \& Krueger Coll.) from Niederfinow (Brandenburg); lateral view of specimen. Scale bar units $=1 \mathrm{~mm}$.

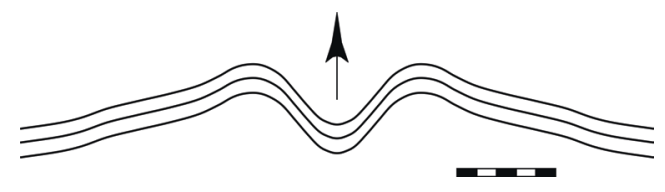

Fig. 44. Lituites toernquisti Holm, 1891 from the Upper Grey Orthoceratite Limestone; lirae in specimen MB.C.30534 (Neben \& Krueger Coll.) from Niederfinow (Brandenburg), at wh $=11 \mathrm{~mm}$. Scale bar units $=1 \mathrm{~mm}$. 
are much larger in overall proportions (diameter of the coiled part $\sim 30 \mathrm{~mm}$ ) and have greater expansion angles $\left(7^{\circ}\right)$.

Lituites toernquisti may be difficult to distinguish from Trilacinoceras discors when the body chamber is not completely preserved. However, L. toernquisti belongs to Lituites because it possesses a fivelappeted aperture (Fig. 43A), i.e., not three-lappeted as is diagnostic for Trilacinoceras (for further discussion, see Holm 1891; Sweet 1958; Aubrechtová \& Meidla 2020). Lituites toernquisti differs from other species of the genus Lituites chiefly by the small size of its conch (coiled part diameters up to $20 \mathrm{~mm}$, whorl height at maturity about $25 \mathrm{~mm}$ ). The only exception to this is L. baculus sp. nov., which is comparable in overall size to L. toernquisti; however, the coiled part in the former species is composed of only 1.5 rapidly expanding volutions and the shell ornament is different (annuli in the coiled part are absent and ornament elements in the backcoiled part have prorsiradiate direction).

\section{Geographic and stratigraphic occurrence}

Sweden (in situ) and northern Germany (in erratics within Pleistocene gravels); Aseri and possibly Lasnamägi regional stages, Darriwilian, Middle Ordovician.

Lituites toernquisti is a stratigraphically significant species in the Upper Red Orthoceratite Limestone of Baltoscandia indicating the late Aserian Lituites toernquisti Zone (Jaanusson \& Mutvei 1953; Evans et al. 2014).

Lituites lasaulxii Remelé, 1890

Fig. 45, Tables 9-11

Lituites Lasaulxii Remelé, 1890: pl. 3 fig. 1.

? Lituites cf. Lasaulxii - Remelé 1890: pl. 6 fig. 2.

Lituites perfectus? - Remelé 1890: pl. 6 fig. 4.

\section{Diagnosis}

Species of the genus Lituites with diameter of the coiled conch of 25-27 mm; coiling tight or almost tight; backcoiled part strongly curved; juvenile expansion angle of ca $5.5^{\circ}$. Shell surface with narrow annuli and very fine lirae in the coiled part and more prominent annuli and lirae after uncoiling; ventral sinus deeply rounded, becoming shallow and wide on the backcoiled part.

\section{Type material}

Lectotype (designated here)

GERMANY • Brandenburg, Heegermühle; Ordovician (late Lasnamägi Regional Stage, late Darriwilian), Upper Grey Orthoceratite Limestone; Kgl. Forstakademie Eberswalde Coll.; illustrated by Remelé (1890: pl. 3 fig. 1), re-illustrated here in Fig. 45A; MB.C.11678.

\section{Additional material}

GERMANY • 1 spec.; Brandenburg, Eberswalde; Ordovician, Upper Grey Orthoceratite Limestone; Remelé Coll.; MB.C.11645 • 1 spec.; Brandenburg, Heegermühle; Ordovician, Upper Grey Orthoceratite Limestone; Kgl. Forstakademie Eberswalde Coll.; MB.C.11677.

\section{Description}

Lectotype MB.C.11678 (Fig. 45A) consists of the coiled part ( $\mathrm{dm}=28 \mathrm{~mm}$; only the last three quarters of the last volution are preserved, coiling is probably nearly tight or tight) and the backcoiled part (length $=93 \mathrm{~mm} ; \mathrm{wh}=18.4 \mathrm{~mm} ; \mathrm{EA}=5.6^{\circ}$ ) of the conch. The shell surface is preserved mainly in the 
coiled part and the beginning of the backcoiled part; there the ornament consists of raised lirae (up to $1.2 \mathrm{~mm}$ apart); ventrolaterally they bend steeply backwards to form a deep, U-shaped ventral sinus. The ornament grades into marked annuli (up to $3.4 \mathrm{~mm}$ apart) with lirae during ontogeny; the ventral sinus becomes wide. After uncoiling of the conch, there are two conspicuous, raised lines of ornament. The development of the ornament can be subdivided into four successive stages: (1) The last whorl bears lirae, which run almost straight on the inner half of the flank and bend into a narrow projection in the ventrolateral area. The lirae are almost $1 \mathrm{~mm}$ apart (on the mid-flank). (2) In the transition from the coiled part to the backcoiled part, the distances between the lirae decrease for a length of $11 \mathrm{~mm}$. The distances between the lirae are somewhat irregular between 0.3 and $0.5 \mathrm{~mm}$. (3) In the following area of the backcoiled part of about $7.5 \mathrm{~mm}$ in length, flat annuli appear for the first time; these are superimposed by very fine growth lines. The annuli alternate with some intermediate lirae that form groups of three or four. (4) The remaining extent of the backcoiled and straight part has then only annuli with intervals of 2.5 to $3.5 \mathrm{~mm}$. They are occupied by fine growth lines with 0.1 to $0.15 \mathrm{~mm}$ wide intervals. At this stage the growth lines extend with shallow lateral sinus, low ventrolateral projection, and shallow, broadly rounded ventral sinus.
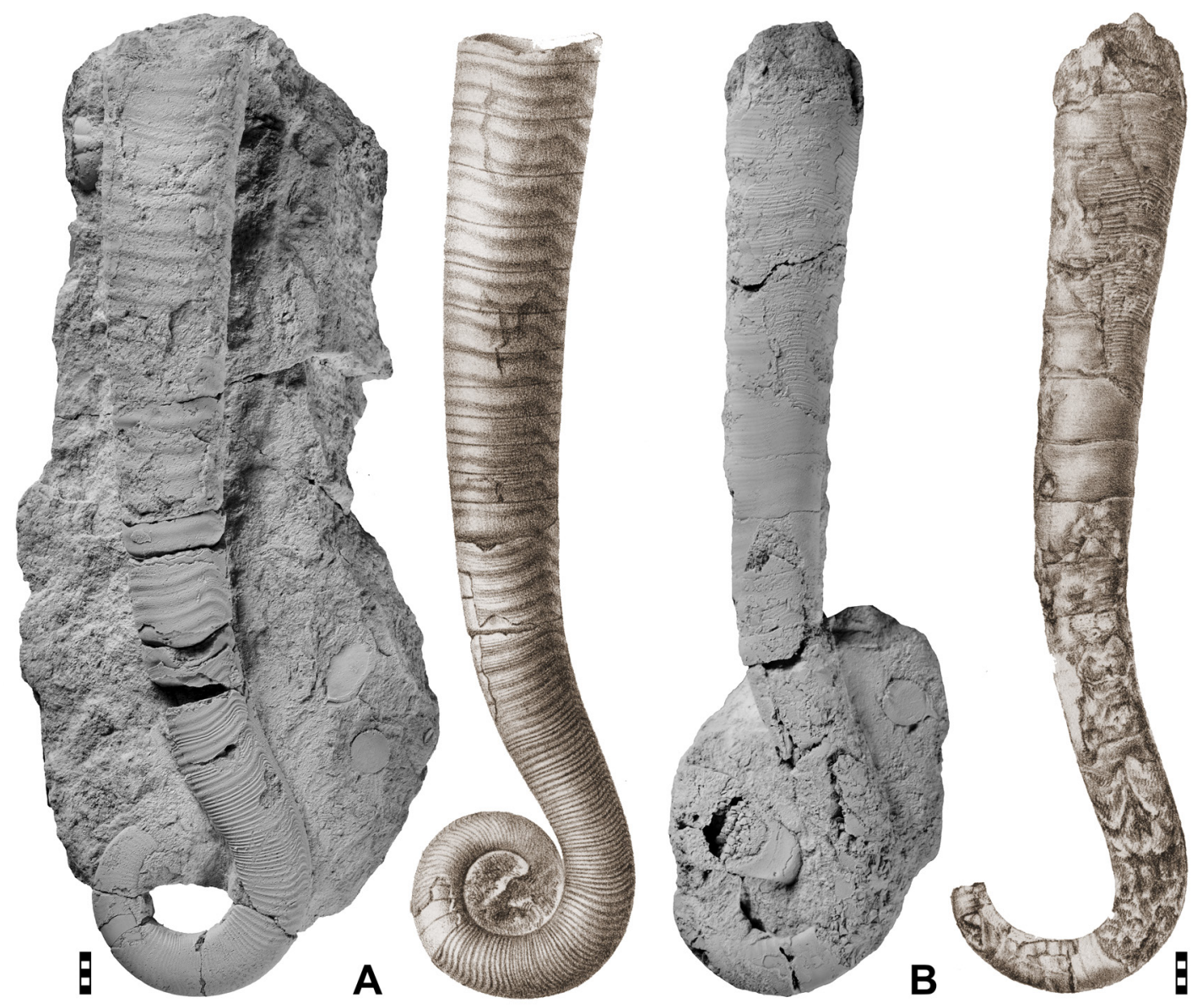

Fig. 45. Lituites lasaulxii Remelé, 1890 from the Upper Grey Orthoceratite Limestone. A. Lectotype MB.C.11678 (Kgl. Forstakademie Eberswalde Coll.) from Heegermühle (Brandenburg); photograph and reproduction of the illustration by Remelé (1890: pl. 3 fig. 1). B. Specimen MB.C.11645 (Remelé Coll.) from Eberswalde (Brandenburg); photograph and reproduction of the illustration by Remelé (1890: pl. 6 fig. 4). Scale bar units $=1 \mathrm{~mm}$. 
Specimen MB.C.11645 (Fig. 45B) is similar to the lectotype in general proportions and shape. The shell ornament has wider and flatter annuli in the uncoiled part of the conch.

\section{Remarks}

Specimen MB.C.11677 (Remelé 1890: pl. 6 fig. 2) is a laterally compressed and crushed, straight phragmocone, which is ornamented by narrow, regularly spaced annuli similar to those of the lectotype. However, the specimen differs from the lectotype in having a lower expansion angle $\left(4^{\circ}\right)$. Because the specimen in discussion does not have anything of the coiled part preserved, it is placed in open nomenclature as Lituites cf. lasaulxii.

Lituites lasaulxii is most similar to L. lituus but differs in the stronger curvature of the backcoiled part; also, in L. lasaulxii, annuli are not developed at the coiled part of the conch and in the straight part, annuli are covered by growth lines instead of lirae.

\section{Geographic and stratigraphic occurrence}

Northern Germany (in erratics within Pleistocene gravels); late Darriwilian, Middle Ordovician.

Lituites fallax Remelé, 1890

Fig. 46, Table 9

Lituites fallax Remelé, 1890: 59, pl. 5 fig. 1.

\section{Diagnosis}

Species of the genus Lituites with coiled conch diameter of ca $40 \mathrm{~mm}$; whorl expansion rate 1.70. Shell surface of the coiled part of lirae $(0.5-1.0 \mathrm{~mm}$ apart), raised in ca $2 \mathrm{~mm}$ wide intervals. Deep, rounded ventral sinus, very low dorsal projection; lirae straight laterally, direction rectiradiate.

\section{Type material}

Lectotype (designated herein)

GERMANY • Brandenburg, Heegermühle; Ordovician (late Lasnamägi Regional Stage, late Darriwilian), Upper Grey Orthoceratite Limestone; Ramann Coll.; previously illustrated by Remelé (1890: pl. 5 fig. 1), re-illustrated here in Fig. 46; MB.C.11672.2.

\section{Description}

Lectotype MB.C.11672.2 (Fig. 46) is a fragment of a third of the last whorl of the coiled part (40 mm estimated diameter; $\left.\mathrm{WER}_{\mathrm{ah}} \sim 1.70\right)$ of a conch. The ornament consists of sharp lirae (0.5-1.0 mm apart), raised in more or less regular intervals (every ca $2 \mathrm{~mm}$ ); the lirae are straight on the flanks, with a narrow ventrolateral projection. The ventral sinus is deep and rounded, dorsal projection is very low with a shallow dorsolateral sinus.

\section{Remarks}

The lectotype of Lituites fallax is incompletely preserved and therefore, it cannot be excluded that it represents a morphological variant of some other species of the genus Lituites. Most similar to L. fallax are $L$. kruegeri sp. nov. and $L$. cf. kruegeri, both of which differ from L. fallax in having a smaller conch diameter ( 33 and $28 \mathrm{~mm}$, respectively) and a higher $\mathrm{WER}_{\text {ah }}$ ( 2 and 2.30, respectively). Also, L. fallax is ornamented with lirae, which are straight on the flanks, while prorsiradiate lirae and flat annuli are developed in L. kruegeri sp. nov. (Fig. 8) and also in L. cf. kruegeri. Some specimens of L. perfectus have a large conch diameter (39 mm in the neotype MB.C.30544) and a low WER ah $_{\text {(1.9 }}$ in MB.C.30544 and MB.C.30545) as L. fallax but the former species differs in the shell ornament of the coiled part; 

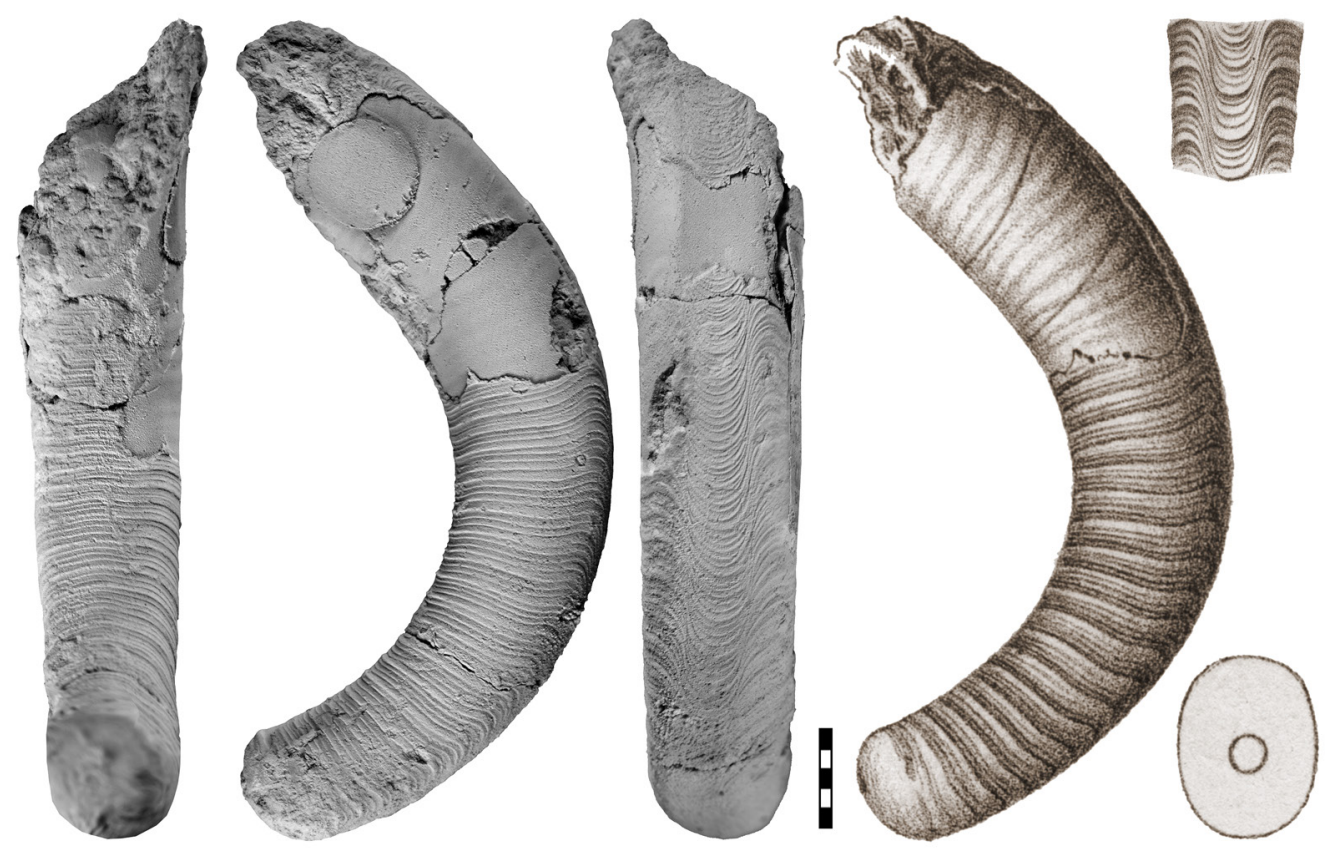

Fig. 46. Lituites fallax Remelé, 1890 from the Upper Grey Orthoceratite Limestone. Lectotype MB.C.11672.2 (Ramann, Kgl. Forstakademie Eberswalde Coll.) from Heegermühle (Brandenburg, Germany); photograph (with dorsal, lateral and ventral views) and reproduction of the illustration by Remelé (1890: pl. 5 fig. 1). Scale bar units $=1 \mathrm{~mm}$.

it consists of growth lines and rectiradiate annuli or ribs instead of sharp lirae. With only the holotype MB.C.11672.2 at hand, it is therefore not possible to confidently synonymise L. fallax with any other species of the genus Lituites.

Remelé (1890: pl. 1 fig. 3) assigned a second specimen (MB.C.11673.2) from coeval strata to Lituites fallax? but in this specimen nothing of the coiled part is preserved and hence its correspondence to the holotype cannot be validated. Holm (1891) and Sweet (1958) argued that the specimen probably represents Trilacinoceras discors. Indeed, this specimen is similar in ornament, expansion angle and general adult size to T. discors. However, the specimen is still chambered and its whorl profile is circular. Its identity is thus left unresolved herein; the holotype remains the only specimen unequivocally attributable to L. fallax.

Lituites procerus Remelé, 1890

Figs 47-49, Tables 9-10

Lituites procerus Remelé, 1890: 57, pl. 6 fig. 1.

non Lituites procerus - Foerste 1932: 166, text-fig. 7.

\section{Diagnosis}

Species of the genus Lituites with a coiled conch $24-30 \mathrm{~mm}$ in diameter; coiling tight or almost tight, 2.5-3 volutions; whorl expansion rate 2.10-2.50. Uncoiled part straight or slightly curved, juvenile expansion angle of up to $5^{\circ}$. Shell surface with widely spaced ribs or annuli and prominent, widely spaced lirae. Ornament elements biconvex or concavo-convex in the coiled part, and concavo-convex in the backcoiled part; ventral sinus deep and rounded, with ventral band (after Balashov 1953, emended). 


\section{Type material}

\section{Lectotype}

Not available for study, designated by Balashov (1953); illustrated by Remelé (1890: pl. 6 fig. 1) and reproduced here in Fig. 47D. It is from Drewin near Neustrelitz (Mecklenburg-Vorpommern, Germany), Upper Grey Orthoceratite Limestone erratics from Pleistocene gravel (late Darriwilian, Middle Ordovician).

\section{Material examined}

GERMANY • 1 spec.; Brandenburg, Hohensaaten; Ordovician, Upper Grey Orthoceratite Limestone; Neben and Krueger Coll.; MB.C.30546 • 1 spec.; Brandenburg, Niederfinow; Ordovician, Upper Grey Orthoceratite Limestone; MB.C.2498 - 1 spec.; Brandenburg, Oderberg; Ordovician, Upper Grey Orthoceratite Limestone; Krueger Coll.; MB.C.30547.

\section{Description}

Specimen MB.C.2498 (Fig. 47C) consists of a nearly complete coiled part ( $\mathrm{dm}=30 \mathrm{~mm} ; 2.5$ essentially tight, barely detached volutions; Fig. 48F-J) and a short part of the backcoiled part (length $=15 \mathrm{~mm}$; $\mathrm{wh}=9.8 \mathrm{~mm} ; \mathrm{EA}<1^{\circ}$ ). The ornament is produced by ribs (up to $3.5 \mathrm{~mm}$ apart) and lirae (up to $0.5 \mathrm{~mm}$ apart). The spacing of ribs and lirae increases gradually and regularly during ontogeny. Their ventral sinus is deep and rounded. In the coiled part of the conch, the ornament elements are biconvex; in the backcoiled part, they are concavo-convex and form a shallow lateral sinus.
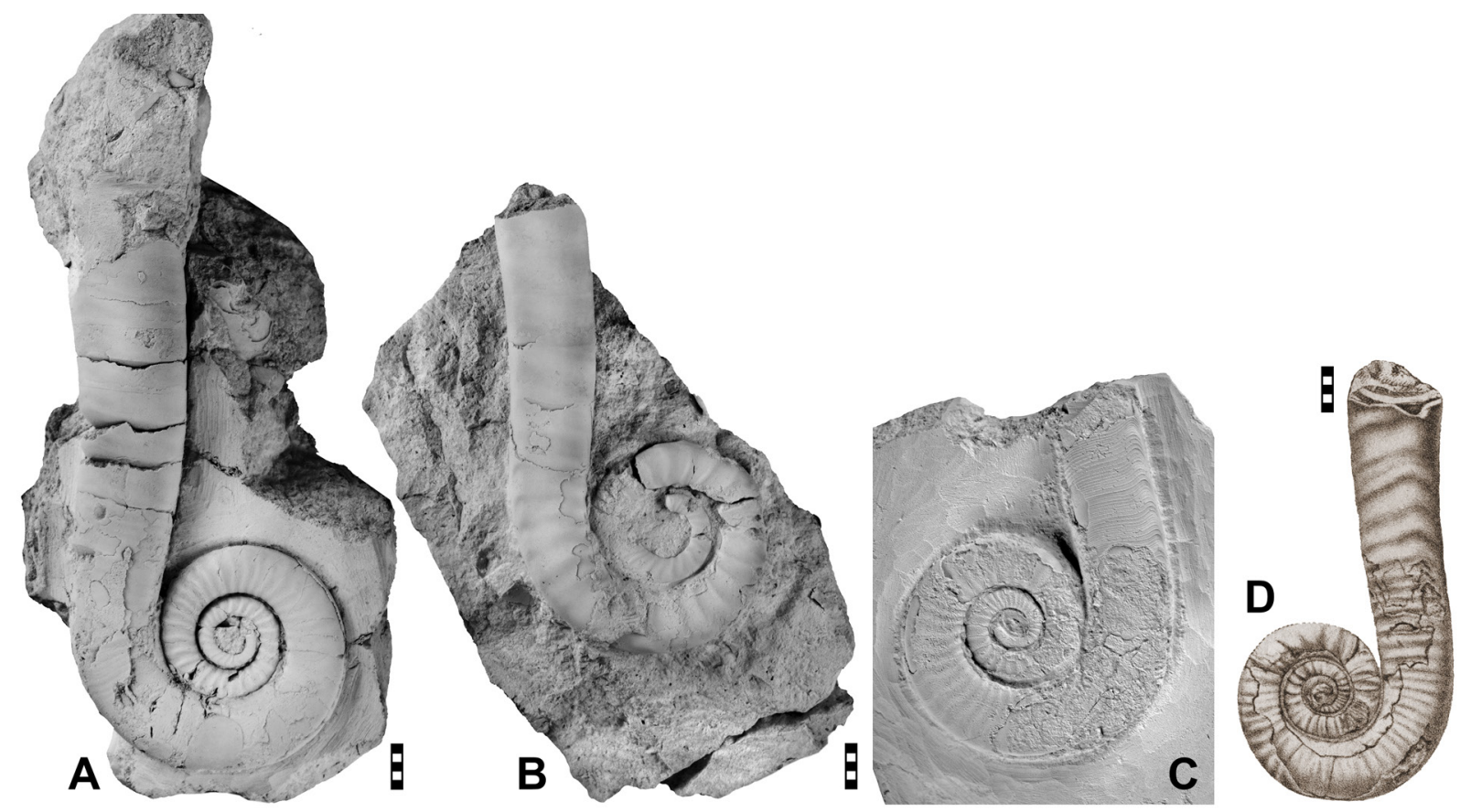

Fig. 47. Lituites procerus Remelé, 1890 from the Upper Grey Orthoceratite Limestone. A. Specimen MB.C.30547 (Krueger Coll.) from Oderberg (Brandenburg). B. Specimen MB.C.30546 (Neben \& Krueger Coll.) from Hohensaaten (Brandenburg). C. Specimen MB.C.2498 from Niederfinow (Brandenburg). D. Reproduction of the illustration by Remelé (1890: pl. 6 fig. 1). Scale bar units = $1 \mathrm{~mm}$. 
Specimen MB.C.30546 (Fig. 47B) is a part and counterpart of the coiled part ( $\mathrm{dm}=25 \mathrm{~mm} ; 1.5$ nearly tight, slightly detached volutions;) and a short part of the backcoiled part (length $=28 \mathrm{~mm}$; $w h=10 \mathrm{~mm}$; EA $\sim 1.5^{\circ}$ ). The ornament has coarse annuli, which are less than $1 \mathrm{~mm}$ in distance in the coiled part and towards backcoiled part of the specimen they are broad and flat and $4 \mathrm{~mm}$ apart. The spacing of annuli increases gradually and regularly during ontogeny. Lirae are not visible. The CLR is between 0.53 and 0.79 , without an ontogenetic trend.

Specimen MB.C.30547 (Fig. 47A) consists of the nearly complete coiled part (dm $=33 \mathrm{~mm} ; 2.5$ tightly coiled volutions; Fig. 48A-E) and a short part of the backcoiled part (length $=33 \mathrm{~mm}$; $w h=13 \mathrm{~mm}$; EA $\left.\sim 5^{\circ}\right)$. The ornament has coarse annuli (1-2 mm apart), lirae are not visible. The phragmocone chambers are variable in length (CLR between 0.24 and 0.58), without an ontogenetic trend (Fig. 49).

\section{Remarks}

Lituites procerus is most similar to L. lituus, because it is tightly coiled with conch diameters of up to $30 \mathrm{~mm}$; however, the uncoiled part in L. lituus is moderately curved with a greater expansion angle $\left(5^{\circ}-8^{\circ}\right)$. Lituites clavis $\mathrm{sp}$. nov. is also tightly coiled but its conch diameter is larger $(34 \mathrm{~mm})$ and the uncoiled conch part is moderately curved.
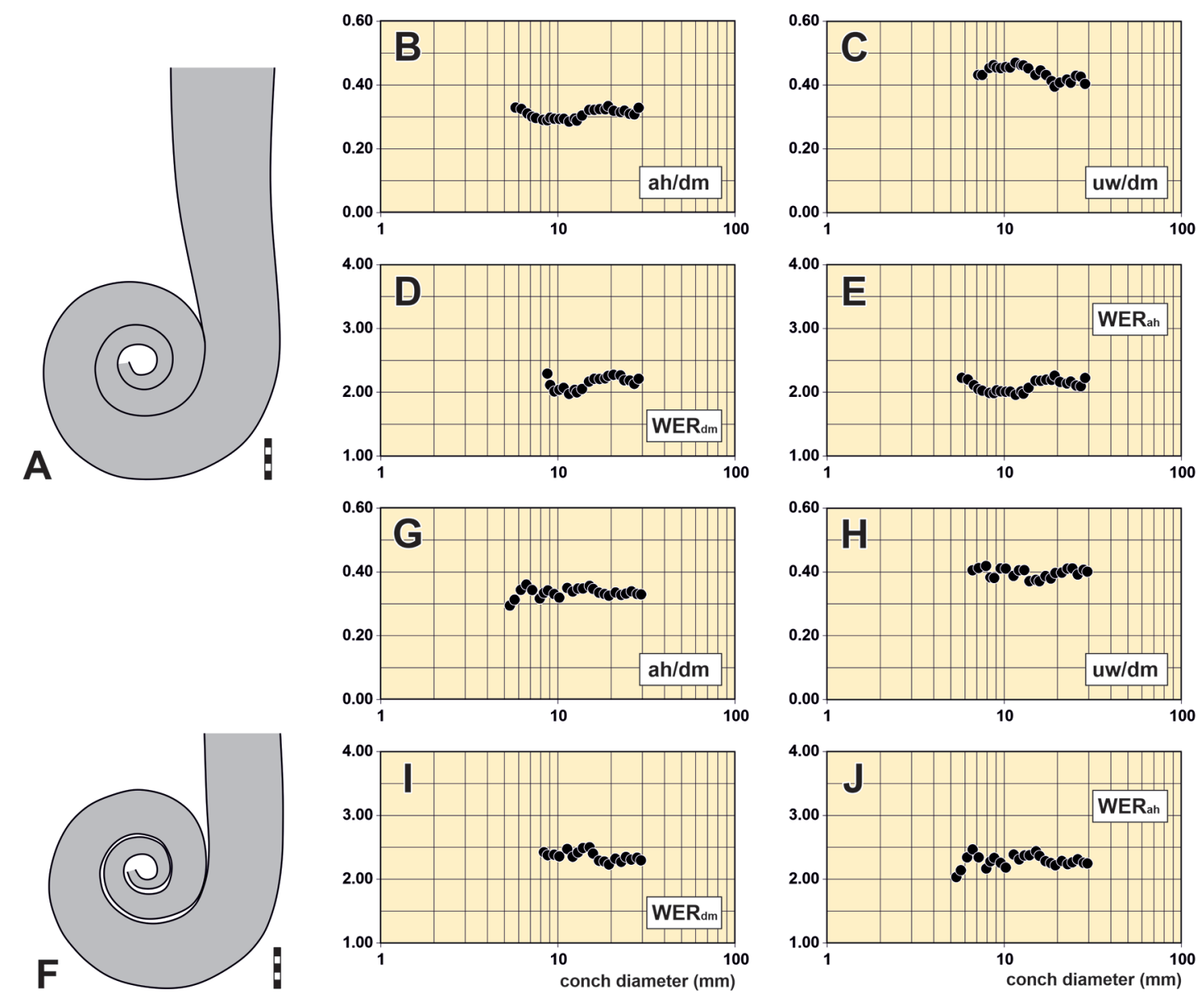

Fig. 48. Lituites procerus Remelé, 1890. A. Outline of coiled conch part of specimen MB.C.30547. B-E. Conch proportions and coiling rates of specimen MB.C.30547. F. Outline of coiled conch part of specimen MB.C.2498. G-J. Conch proportions and coiling rates of specimen MB.C.2498. Scale bar units $=1 \mathrm{~mm}$. 

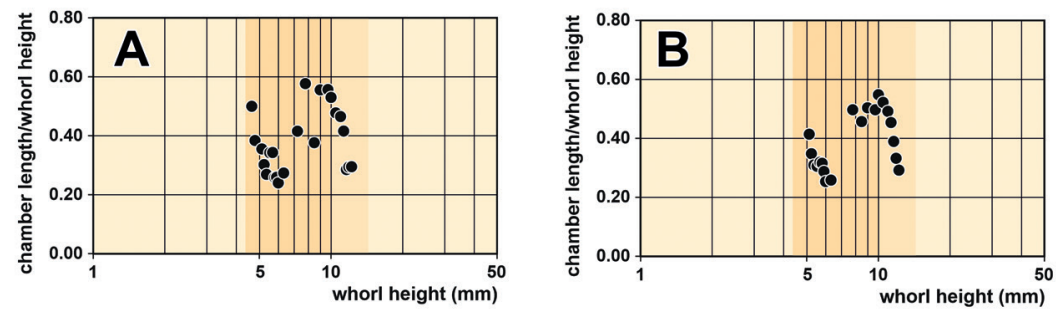

Fig. 49. Lituites procerus Remelé, 1890, chamber length/whorl height of specimen MB.C.30547 (Krueger Coll.) from Oderberg (Brandenburg). A. Empirical data. B. Three data point averaged.

The variation of Lituites procerus concerns mainly the expansion angle at the beginning of the uncoiled stage; it is lower in specimens MB.C.2498 and MB.C.30546 but higher in the specimen figured by Remelé (1890) and specimen MB.C.30547. Furthermore, the latter specimen has narrower lirae at the end of the uncoiled part. Specimen MB.C.2498 is also unique due to the presence of biconvex ribs in the coiled part of the conch.

The late Darriwilian specimen figured by Balashov (1953: pl. 14 fig. 2) from northern Estonia has coarse annuli in the coiled and uncoiled part of the conch and the backcoiled part is rather strongly curved; the specimen is thus here attributed to L. lituus.

\section{Geographic and stratigraphic occurrence}

Northern Germany, Upper Grey Orthoceratite Limestone erratics from Pleistocene gravel (late Darriwilian, Middle Ordovician).

Lituites tenuicaulis Remelé, 1890

Figs 50-53, Tables 9-11

Lituites tenuicaulis Remelé, 1890: pl. 3 fig. 2.

Lituites procerus - Foerste 1932: 166, text-fig. 7.

Lituites tenuicaulis - Balashov 1953: 231, pl. 14 fig. 1. — Aubrechtová \& Meidla 2020: 278.

\section{Diagnosis}

Species of the genus Lituites with the coiled conch $30 \mathrm{~mm}$ in diameter; $2-3$ tightly coiled whorls, only the mid-part of the last whorl sometimes detached; whorl expansion rate 1.90-2.30. Uncoiled part straight in shape or slightly curved, expansion angle $2-3^{\circ}$. Shell surface in coiled part with fine growth lines and sharp lirae, sometimes with narrow annuli; in the backcoiled part with lirae and low annuli (after Balashov 1953; emended).

\section{Type material}

\section{Lectotype}

GERMANY • Brandenburg, Oderberg; Ordovician (late Lasnamägi Regional Stage, late Darriwilian), Upper Grey Orthoceratite Limestone; Kgl. Forstakademie Eberswalde Coll.; designated by Balashov (1953); illustrated by Remelé (1890: pl. 3 fig. 2), re-illustrated here in Fig. 50A; MB.C.5389. 


\section{Additional material}

GERMANY • 1 spec.; Brandenburg, Eberswalde; Ordovician, Upper Grey Orthoceratite Limestone; Remelé 1884 Coll.; MB.C.11651 - 2 specs; Brandenburg, Niederfinow; Ordovician, Upper Grey Orthoceratite Limestone; Neben and Krueger Coll.; MB.C.30548, MB.C.30549 • 1 spec.; Brandenburg, Ringenwalde; Ordovician, Upper Grey Orthoceratite Limestone; Neben and Krueger Coll.; MB.C.30550.

POLAND • 1 spec.; West Pomerania, Island of Chrząszczewska (former Gristow); Ordovician, Upper Grey Orthoceratite Limestone; Müchner Coll.; MB.C.30551.

\section{Description}

Lectotype MB.C.5389 (Fig. 50A) consists of the coiled part ( $\mathrm{dm}=28 \mathrm{~mm} ; 1.5$ tightly coiled volutions slightly detached in the last half volution) and a part of the backcoiled part (length $=50 \mathrm{~mm}$; wh $=$ $12.4 \mathrm{~mm} ; \mathrm{EA}=2.7^{\circ}$ ). The whorl profile is compressed (WWI $=0.88$ ). The shell wall is preserved only in the last portion of the coiled part; there the ornament consists of sharp lirae (less than $1 \mathrm{~mm}$ apart) and fine growth lines between them. The backcoiled part of the specimen additionally shows imprints of annuli of about $1 \mathrm{~mm}$ apart. The chamber length increases during ontogeny from CLR $\sim 0.36$ to $\sim 0.52$ (Fig. 52A-B). The siphuncle is visible at the last preserved septum, where it has a relative diameter of 0.18 and a position of 0.32 .

A more completely preserved ornament is seen in the specimen MB.C.30551 (Fig. 50B). In this specimen, the coiled part has lirae and narrow annuli, which grade into flat annuli after uncoiling (3-4 mm apart). The annuli of the backcoiled part have coarse lirae in between them (0.3-0.5 mm apart). The ventral sinus of ornament elements is deep and rounded (Fig. 53). In the coiled part, the ornament elements are laterally straight, while in the backcoiled part, they have a shallow lateral sinus.
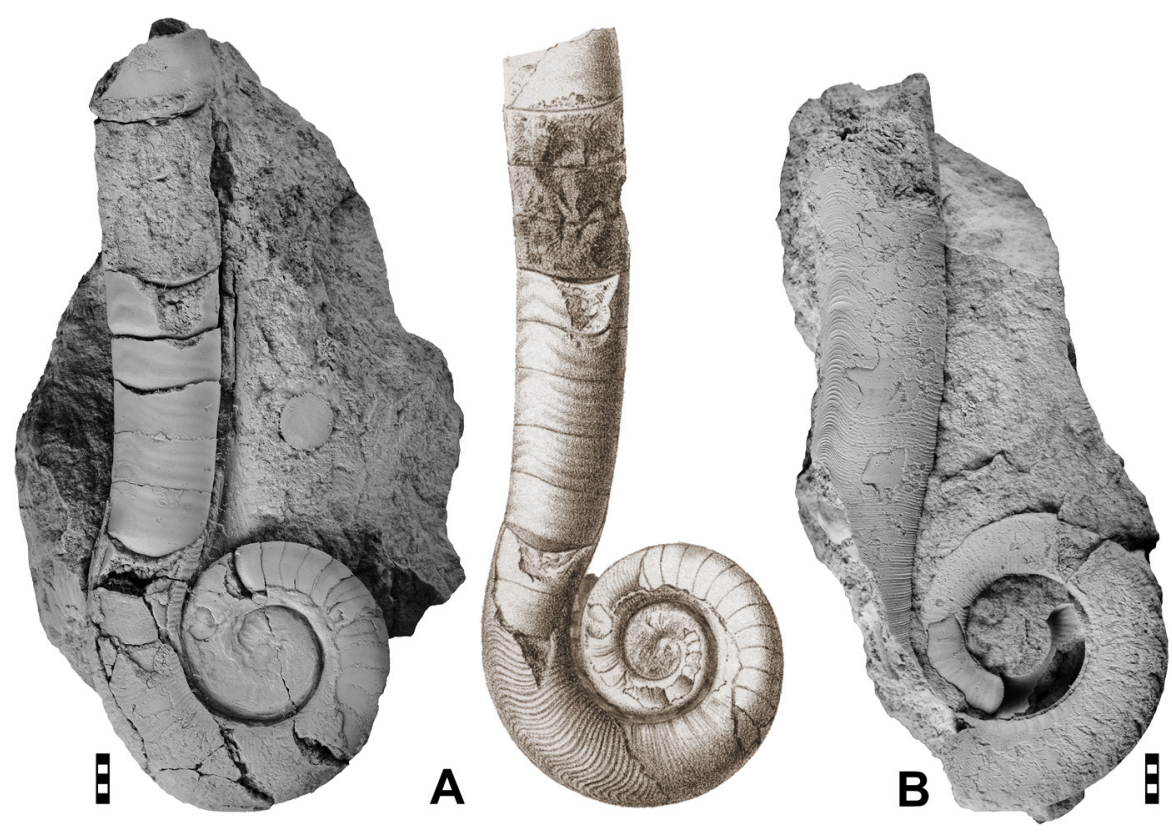

Fig. 50. Lituites tenuicaulis Remelé, 1890 from the Upper Grey Orthoceratite Limestone. A. Lectotype MB.C.5389 (Kgl. Forstakademie Eberswalde Coll.) from Oderberg (Brandenburg); photograph and reproduction of the illustration by Remelé (1890: pl. 3 fig. 2). B. Specimen MB.C.30551 (Münchner Coll.) from Island of Chrząszczewska (former Gristow; West Pomerania, Poland). Scale bar units = $1 \mathrm{~mm}$. 
Specimen MB.C.30548 has a well-preserved coiled part (Fig. 51), which consists of nearly two tightly coiled volutions that are slightly detached in the last half volution. By contrast to the lectotype, the chamber length in MB.C.30548 decreases during ontogeny from CLR $\sim 0.40$ to $\sim 0.25$ (Fig. 52C-D).

\section{Remarks}

Lituites tenuicaulis is distinguished from other species of Lituites by a comparatively large, tightly or nearly tightly coiled conch, an almost straight, slowly expanding backcoiled part and an ornament with lirae in the coiled part, low and wide annuli in the backcoiled part. In these characters, the species is similar to Trilacinoceras discors but that species has smaller, more slender and openly coiled conch.
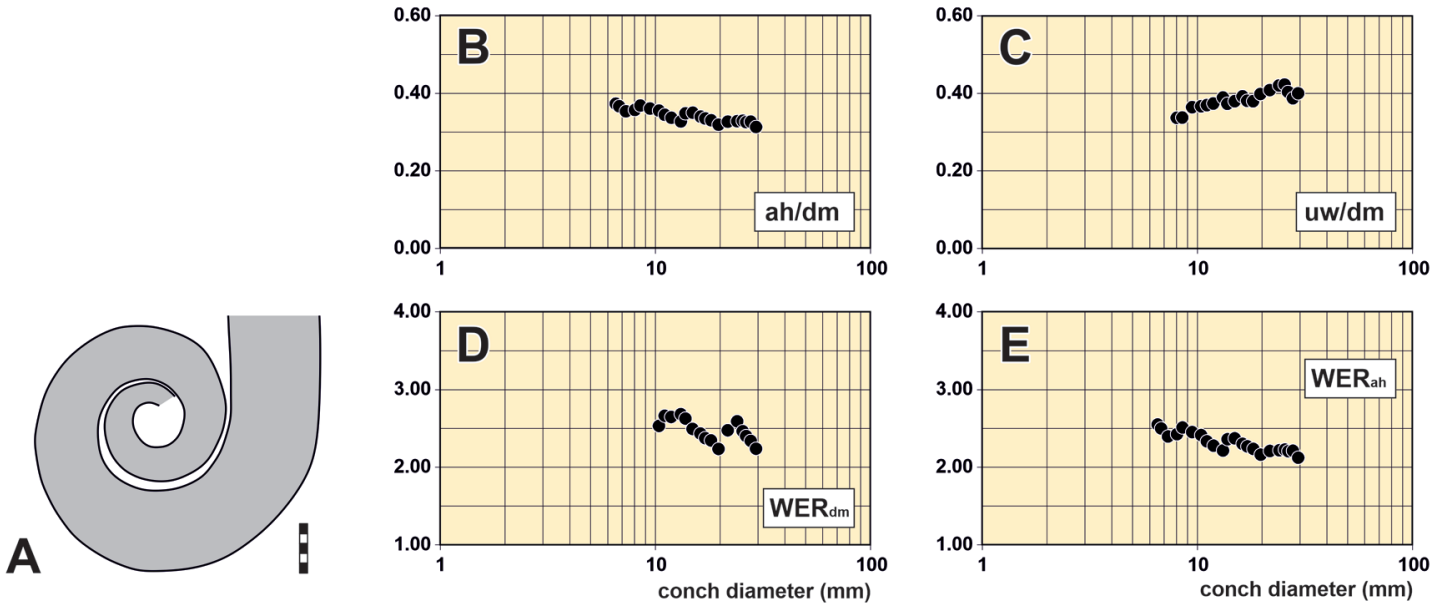

Fig. 51. Lituites tenuicaulis Remelé, 1890. A. Outline of coiled conch part of specimen MB.C.30548. B-E. Conch proportions and coiling rates of specimen MB.C.30548. Scale bar units $=1 \mathrm{~mm}$.
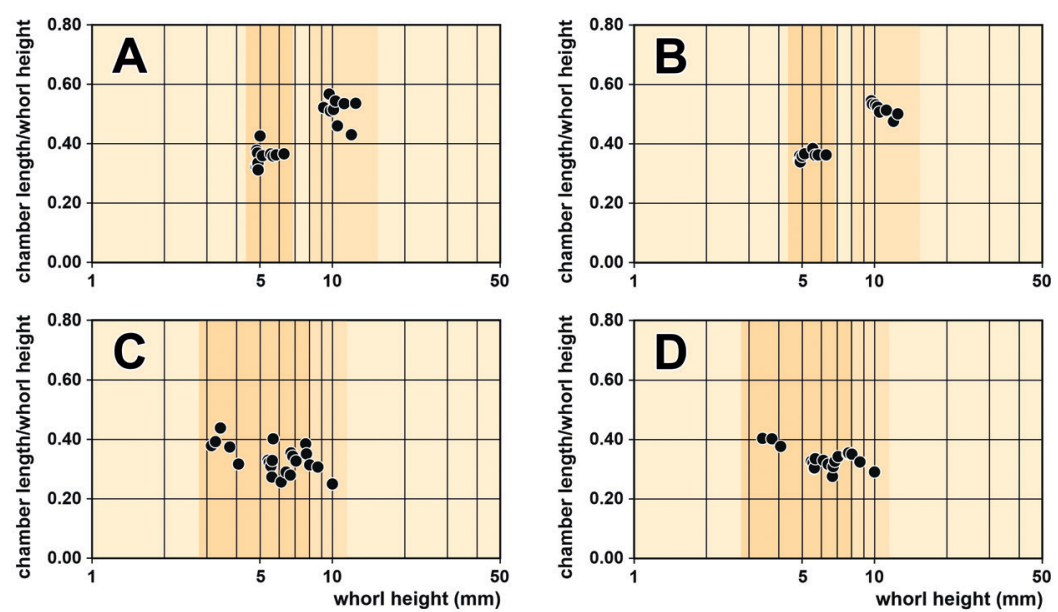

Fig. 52. Septum distances in Lituites tenuicaulis Remelé, 1890 from the Upper Grey Orthoceratite Limestone. A, C = empirical data points; $\mathrm{B}, \mathrm{D}=$ three data points averaged. A-B. Lectotype MB.C.5389 (Kgl. Forstakademie Eberswalde Coll.) from Oderberg (Brandenburg). C-D. Specimen MB.C.30548 (Neben \& Krueger Coll.) from Niederfinow (Brandenburg). 


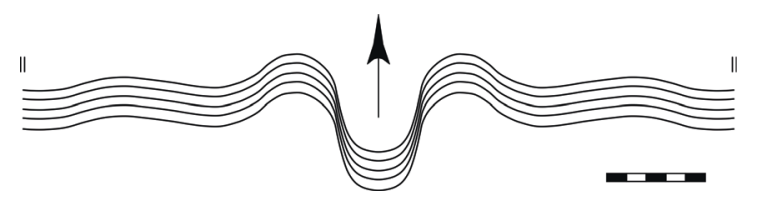

Fig. 53. Lituites tenuicaulis Remelé, 1890 from the Upper Grey Orthoceratite Limestone; lirae in specimen MB.C.30551 (Münchner Coll.) from Island of Chrząszczewska (former Gristow; West Pomerania, Poland), at $\mathrm{wh}=12.5 \mathrm{~mm}$. Scale bar units $=1 \mathrm{~mm}$.

\section{Geographic and stratigraphic occurrence}

Estonia (in situ), northern Germany and northern Poland (in erratics within Pleistocene gravels); late Darriwilian, Middle Ordovician.

Lituites baculus sp. nov. urn:1sid:zoobank.org:act:4683F88A-1A93-436C-87E0-6A8E2996F9A8

Figs 54A, 55, Tables 9-11

\section{Diagnosis}

Species of the genus Lituites with a small coiled part (ca $21 \mathrm{~mm}$ in diameter); 1.5 tightly coiled volutions (only the last half volution slightly detached). Whorl expansion rate 2.70 . Uncoiled part weakly curved, expansion angle $4^{\circ}$. Shell ornament with rectiradiate lirae in the coiled part and lirae (up to $0.5 \mathrm{~mm}$ distance) and annuli (up to $4 \mathrm{~mm}$ apart) in the uncoiled part. Ornament elements in the backcoiled part prorsiradiate with shallow lateral sinus.

\section{Etymology}

From the Latin 'baculus' (nomen) = 'a stick', referring to the shape of the holotype.

\section{Type material}

\section{Holotype}

SWEDEN • Island of Öland, Gärdslösa; Middle Ordovician; Bottke Coll.; MB.C.29654 (illustrated in Fig. 54A).

\section{Description}

Holotype MB.C. 29654 (Fig. 54A) consists of the complete coiled part ( $\mathrm{dm}=20.8 \mathrm{~mm} ; 1.5$ tightly coiled volutions, of which the last half volution is slightly detached from the preceding; $\mathrm{WER}_{\mathrm{ah}}=2.70$; Fig. 55) and the weakly curved backcoiled and straight parts (length $=110 \mathrm{~mm}$; wh $=15.6 \mathrm{~mm}$; EA $\sim 4^{\circ}$ ). The whorl profile is compressed $(\mathrm{WWI}=0.88$ ). The initial chamber of the phragmocone is $0.46 \mathrm{~mm}$ in length and the whorl height at the first septum is $0.94 \mathrm{~mm}$. The ornament is rather coarse and regular. In the coiled part, only transverse, rectiradiate lirae are visible ( $<0.5 \mathrm{~mm}$ apart). In the backcoiled and straight part, coarse annuli are added and are up to $4 \mathrm{~mm}$ apart with lirae of up to $0.5 \mathrm{~mm}$ distance; the ornament elements are prorsiradiate with a shallow lateral sinus. The chamber length ratio is ca 0.44 and increases during ontogeny.

\section{Remarks}

Lituites baculus sp. nov. is most similar to Lituites toernquisti because of the small overall size, the weak curvature of the backcoiled part and relatively low expansion angle of the backcoiled part. However, 
the new species has only 1.5 volutions, which expand rather rapidly (WER 2.70). The shell ornament is also different: L. baculus sp. nov. lacks annuli in the coiled conch part and in the backcoiled part, the ornament elements have prorsiradiate direction.
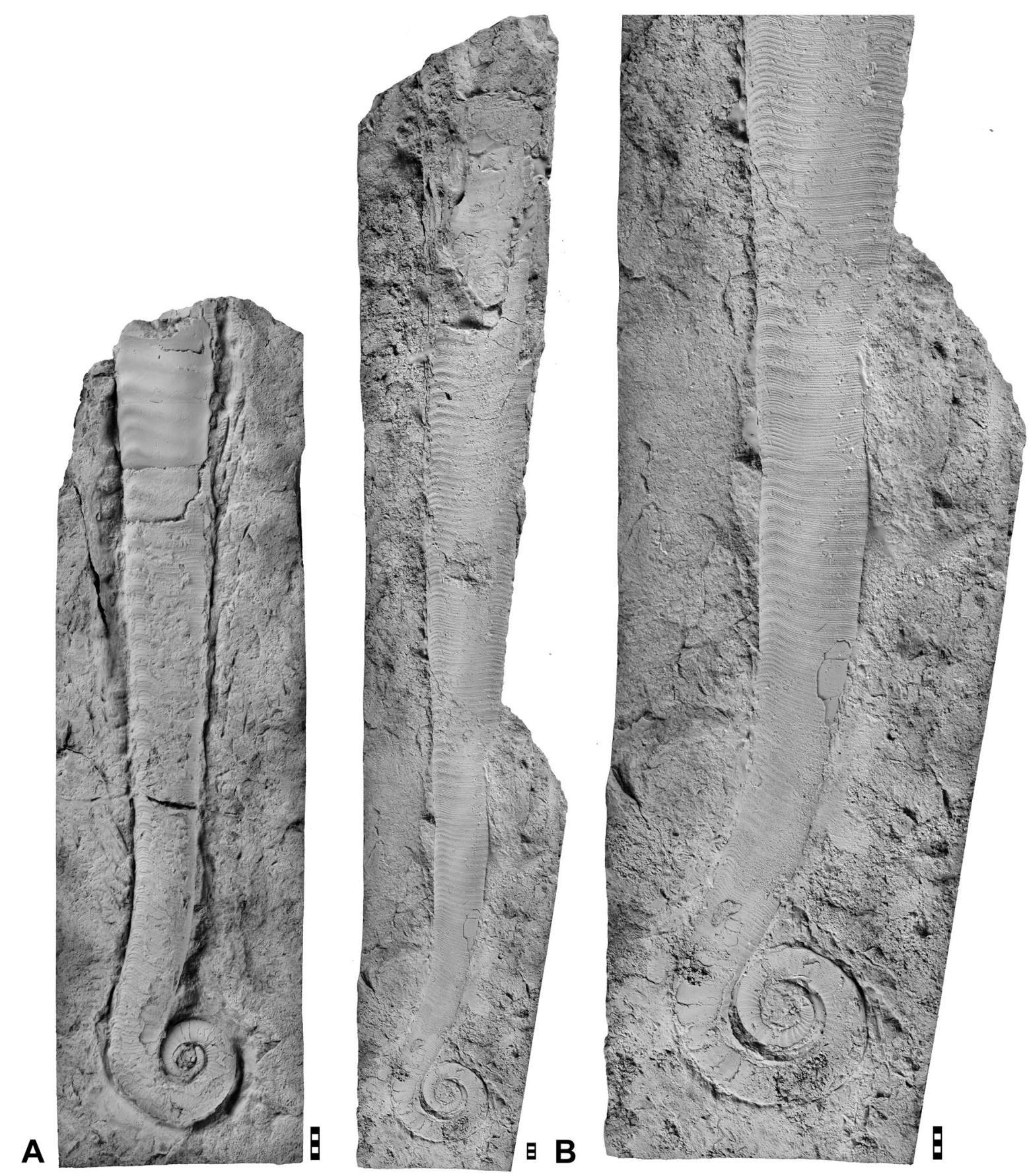

Fig. 54. Species of Lituites from the Middle Ordovician of Gärdslösa (Island of Öland, Sweden). A. Lituites baculus sp. nov., holotype MB.C.29654 (Bottke Coll.). B. Lituites bottkei sp. nov., holotype MB.C.29651 (Bottke Coll.). Scale bar units $=1 \mathrm{~mm}$. 

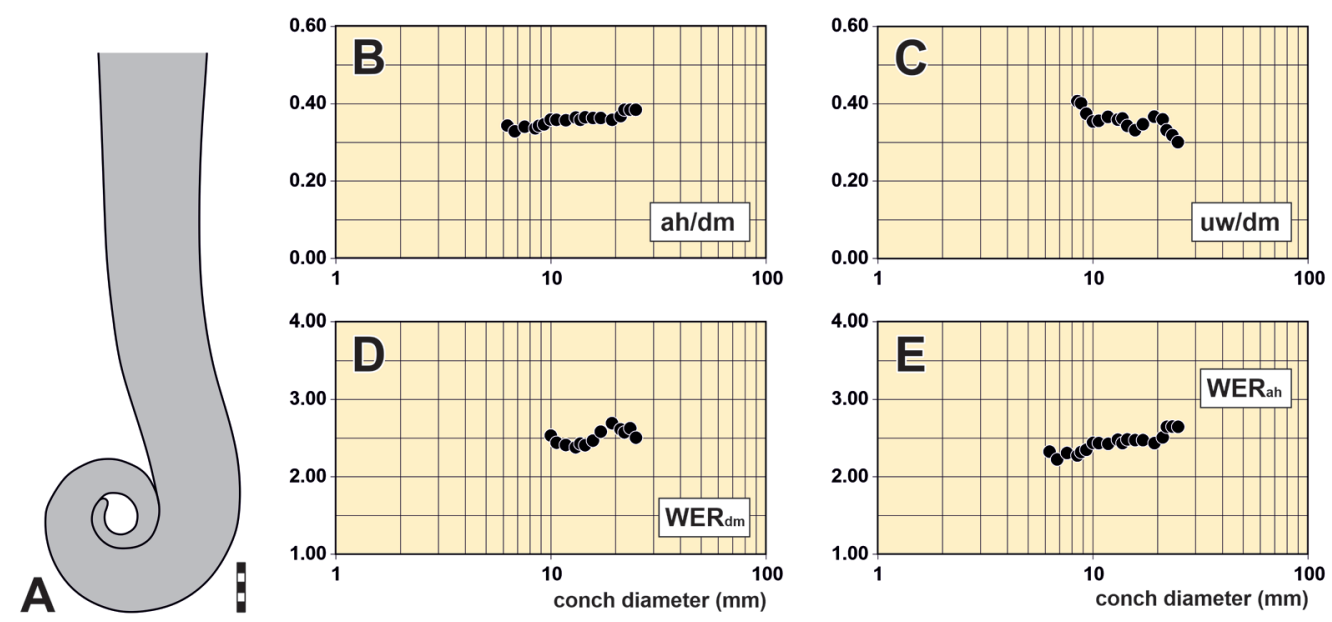

Fig. 55. Lituites baculus sp. nov. A. Outline of coiled conch part of holotype MB.C.29654. B-E. Conch proportions and coiling rates of holotype MB.C.29654. Scale bar units $=1 \mathrm{~mm}$.

Lituites bottkei sp. nov.

urn:1sid:zoobank.org:act:E0CCF553-04EB-4E2C-9E3F-6653ABF2432A

Figs 54B, 56-57, Tables 9-10

\section{Diagnosis}

Species of the genus Lituites with coiled part ca $26 \mathrm{~mm}$ in diameter; coiling open, the last whorl approaches preceding whorls just before uncoiling. Uncoiled part moderately curved, expansion angle $6-7^{\circ}$. Shell ornament with growth lines, transverse lirae and annuli; irregularly developed in thickness and spacing. Ornament elements biconvex in the coiled conch. Ventral sinus moderately deep, lateral sinus wide and shallow, dorsolateral sinus shallow, dorsal projection low.

\section{Etymology}

After the late Werner Bottke (1943-2020), the collector of the holotype.

\section{Type material}

\section{Holotype}

SWEDEN • Island of Öland, Gärdslösa; Middle Ordovician; Bottke Coll.; MB.C.29651 (illustrated in Fig. 54B).

\section{Paratype}

POLAND • West Pomerania, Ustronie Morskie (former Henkengahen); Ordovician; Müldner? Coll.; MB.C.30536.

\section{Description}

Holotype MB.C.29651 (Fig. 54B) consists of the coiled part ( $\mathrm{dm}=26 \mathrm{~mm}$; coiling is open with the whorls not in contact; only the last whorl nearly touches the preceding just before uncoiling; Fig. 56) and the moderately curved backcoiled and straight parts (length $=300 \mathrm{~mm}$; wh $=42 \mathrm{~mm}$; EA $\sim 6^{\circ}$ ). The ornament is best preserved in the penultimate whorl. It is here composed of various successive elements including shallow, rounded annuli, irregularly spaced growth lines and raised lirae. In the backcoiled part, very weak annuli are developed with irregular distances (between 0.5 and $1.0 \mathrm{~mm}$ apart); they 

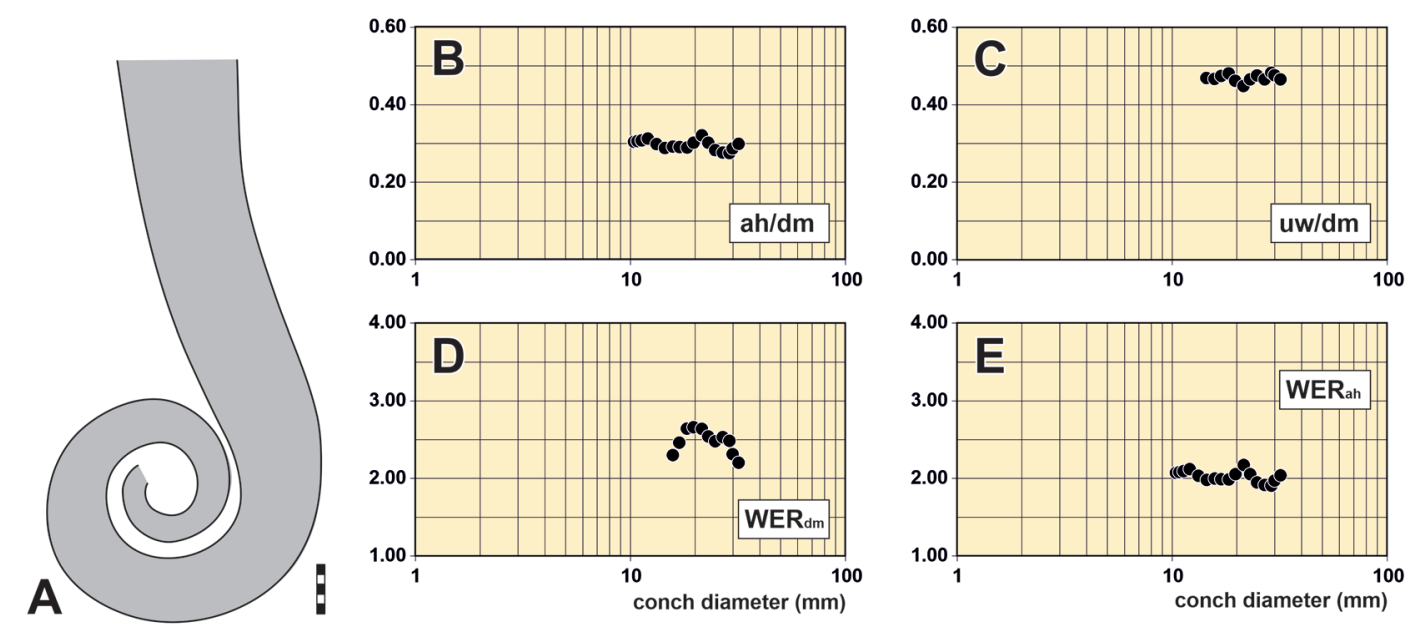

Fig. 56. Lituites bottkei sp. nov. A. Outline of coiled conch part of holotype MB.C.29651. B-E. Conch proportions and coiling rates of holotype MB.C.29651. Scale bar units $=1 \mathrm{~mm}$.

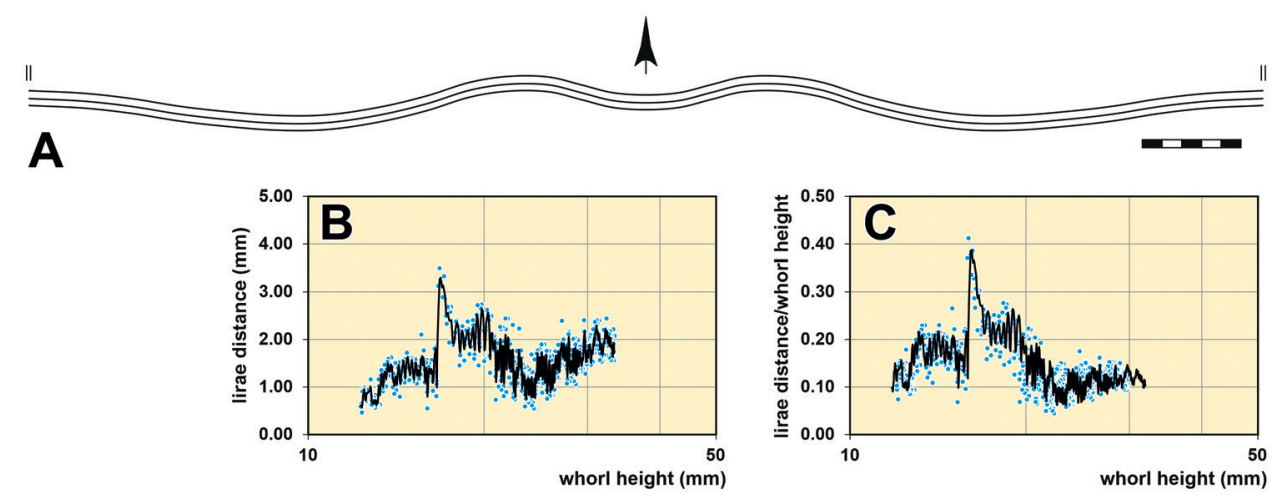

Fig. 57. Lituites bottkei sp. nov. A. Lirae of holotype MB.C.29651 (Bottke Coll.) from Gärdslösa (Island of Öland, Sweden), at wh $=32 \mathrm{~mm}$. B-C. Ontogenetic development of lirae distance (in $\mathrm{mm}$ ) and lirae distance/whorl height of holotype MB.C.29651. Blue dots = individual measurements, black lines = three data point averaged values. Scale bar units $=1 \mathrm{~mm}$.

are particularly well-visible in the ventrolateral area. Lirae $(0.1-0.3 \mathrm{~mm}$ apart) cover the annuli and their interspaces. They are slightly coarser on the ridges of annuli. The ornament elements become progressively more prominent until the beginning of the straight part (wh $\sim 17 \mathrm{~mm}$, Fig. 57), where the shell bears traces of healed injuries (Fig. 6A). For another $21 \mathrm{~mm}$ of conch length following the position of the damage, the shell ornament is composed of widely spaced annuli (ca $4 \mathrm{~mm}$ apart) and lirae (0.6 $\mathrm{mm}$ apart). After that, the annuli become weaker, less regularly developed; at the end of the straight part of the conch, the annuli attain a maximum distance of ca $3 \mathrm{~mm}$. The ornament elements extend with moderately deep ventral sinus, wide and shallow lateral sinus, shallow dorsolateral sinus and low dorsal projection. The chamber length can be measured only locally (CLR between 0.36 and 0.42 ). 


\section{Remarks}

Lituites bottkei sp. nov. differs from L. lituus in the loosely coiled part of the conch and in the ornament, which is generally finer with biconvex course in the coiled conch. Lituites bottkei sp. nov. differs from $L$. perfectus in regular coiling (i.e., the whorls are not eccentric) and greater expansion angle $\left(6^{\circ} \mathrm{vs}\right.$ $1-3^{\circ}$ ) of the uncoiled part.

Specimen MB.T.4492.52 is a nearly complete body chamber with several chambers of the phragmocone, which corresponds to the dimensions and expansion angle of $L$. bottkei sp. nov. However, the ornament is coarser (annuli up to $4 \mathrm{~mm}$ apart) and the specimen is therefore classified as Lituites cf. bottkei.

\section{Geographic and stratigraphic occurrence}

Sweden (in situ) and Poland (in erratics within Pleistocene gravels); Middle Ordovician.

Lituites clavis sp. nov.

urn:1sid:zoobank.org:act:717047ED-9C20-4AE7-B9F8-33C72291029F

Figs 58A, 59, Tables 9-10

Lituites sp. Neben \& Krueger 1971: pl. 31 fig. 3.

\section{Diagnosis}

Species of the genus Lituites with coiled part ca $34 \mathrm{~mm}$ in diameter; three tightly coiled whorls; whorl expansion rate $\sim 2.00$. Backcoiled part moderately curved, expansion angle $\sim 2^{\circ}$. Shell surface in the coiled part with annuli and growth lines and in the uncoiled part with very flat annuli a lirae. Ornament elements in the uncoiled part prorsiradiate.

\section{Etymology}

From the Latin 'clavis' (nomen) = 'a key', referring to the shape of the holotype.

\section{Type material}

\section{Holotype}

GERMANY • Brandenburg, Niederfinow; Ordovician (late Lasnamägi Regional Stage, late Darriwilian), Upper Grey Orthoceratite Limestone; Neben Coll.; MB.C.30537 (illustrated in Fig. 58A).

\section{Description}

Holotype MB.C.30537 (Fig. 58A) consists of the nearly complete coiled part ( $\mathrm{dm}=34 \mathrm{~mm}$; three tightly coiled volutions; WER $=1.90$; Fig. 59 ) and the moderately curved backcoiled part (length $=100 \mathrm{~mm}$; $\mathrm{wh}=16 \mathrm{~mm}$; EA $\sim 2^{\circ}$ ). The ornament undergoes some ontogenetic change: (1) Up to $20 \mathrm{~mm}$ diameter of the coiled conch, annuli are the dominant ornament element; these are particularly coarse and sharp on the inner half of the flank. They stand at distances of about $1 \mathrm{~mm}$ and carry fine growth lines that are strengthened to sharp lirae on the crests of the annuli. Between the crests of the annuli, the growth lines are extremely fine and have distances of less than $0.1 \mathrm{~mm}$. (2) On the last half whorl of the coiled part, the annuli become significantly weaker and are only recognisable as low undulations. The growth lines are now stronger and stand at distances of about $0.15 \mathrm{~mm}$. They are periodically raised to sharp lirae at intervals of about $1 \mathrm{~mm}$. (3) The backcoiled part of the conch shows some remains of the shell with lamellar radial elements. These are flat annuli (3-4 $\mathrm{mm}$ apart) and irregularly placed, flat lirae at distances of $0.5-1.0 \mathrm{~mm}$; both ornament elements leave a faint impression on the internal mould. Lateral sinus is shallow, ornament elements in the uncoiled part are prorsiradiate. The ventral sinus is moderately deep and rounded. The chamber length declines from CLR $=0.50-0.23$ during ontogeny. 


\section{Remarks}

Lituites clavis sp. nov. has a relatively large coiled part, which consists of as many as three volutions. In these characters, the new species is similar to Trilacinoceras knoefleri sp. nov., which differs in the finer shell ornament and a greater expansion angle. Since the mature aperture is not preserved in $L$. clavis sp. nov., it cannot be decided whether the species is indeed a Lituites or a Trilacinoceras. However, the rather coarse shell ornament and the circular whorl profile of the backcoiled part of the conch justifies the classification of L. clavis sp. nov. in the genus Lituites.

Lituites clavis sp. nov. differs from L. lituus by a greater diameter of the coiled part ( $34 \mathrm{~mm}$ but only up to $30 \mathrm{~mm}$ in L. lituus $)$ and a lower expansion angle of the uncoiled part $\left(2^{\circ}\right.$ but $5^{\circ}-8^{\circ}$ in L. lituus $)$; in addition, the annuli at the backcoiled part in L. clavis sp. nov. are flat, not prominent as in L. lituus. Lituites clavis sp. nov. differs from $L$. procerus because its coiled part is larger in diameter $(34 \mathrm{~mm}$ but only up to $30 \mathrm{~mm}$ in $L$. procerus) and its uncoiled part is moderately curved slightly curved or straight in $L$. procerus.
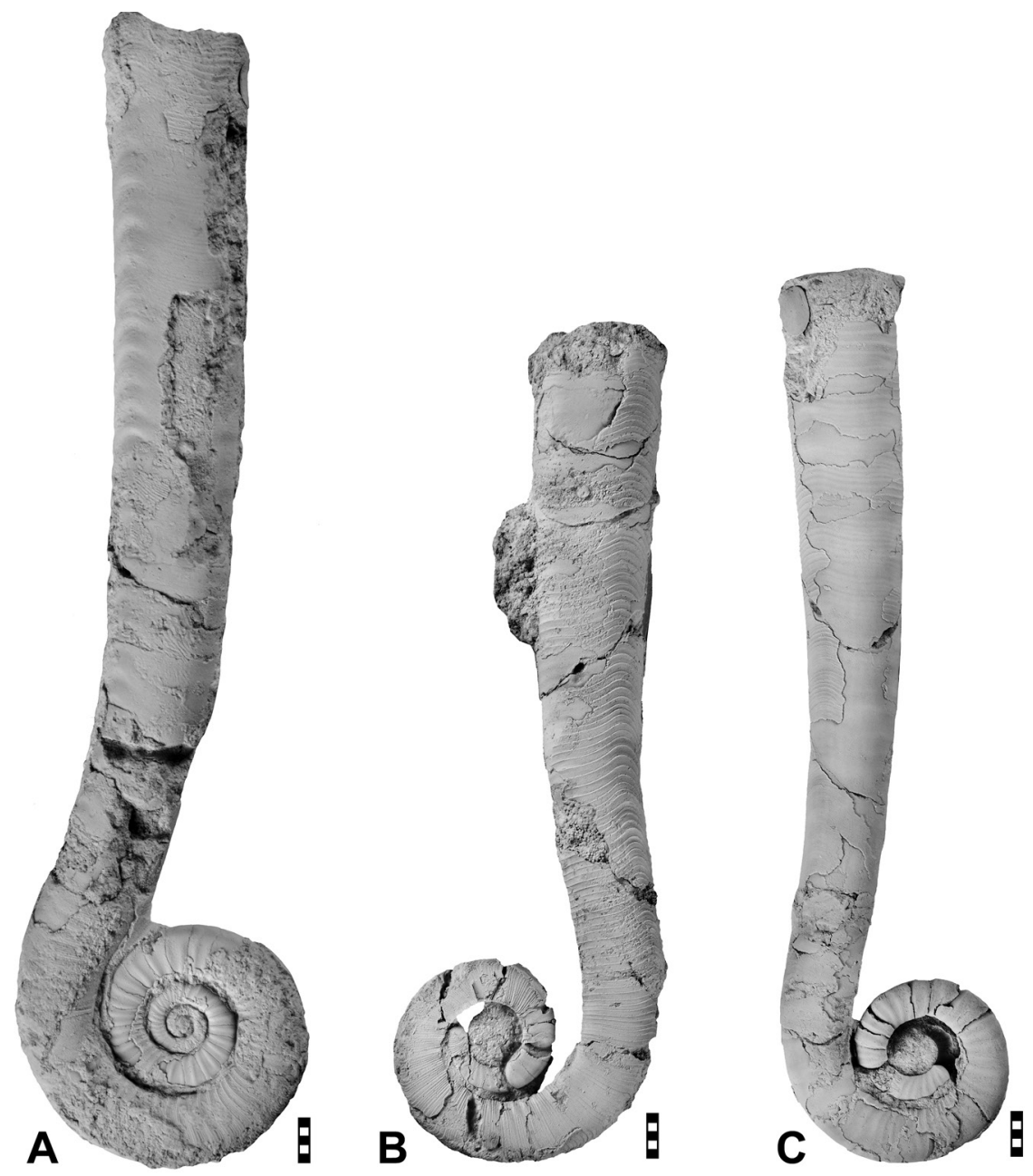

Fig. 58. Species of Lituites from glacial erratics. A. Lituites clavis sp. nov., holotype MB.C.30537 (Neben Coll.) from the Upper Grey Orthoceratite Limestone of Niederfinow (Brandenburg, Germany); previously figured by Neben \& Krueger (1971: pl. 31 fig. 3). B. Lituites dewitzi sp. nov., holotype MB.C.30538 (Neben Coll.) from the Schroeteri Limestone of Boltenhagen near Gross Klütz Höved (Mecklenburg-Vorpommern, Germany). C. Lituites nebeni sp. nov., holotype MB.C.30541 (Neben Coll.) from Upper Grey Orthoceratite Limestone of Niederfinow (Brandenburg, Germany); previously figured by Neben \& Krueger (1971: pl. 31 fig. 2). Scale bar units $=1 \mathrm{~mm}$. 

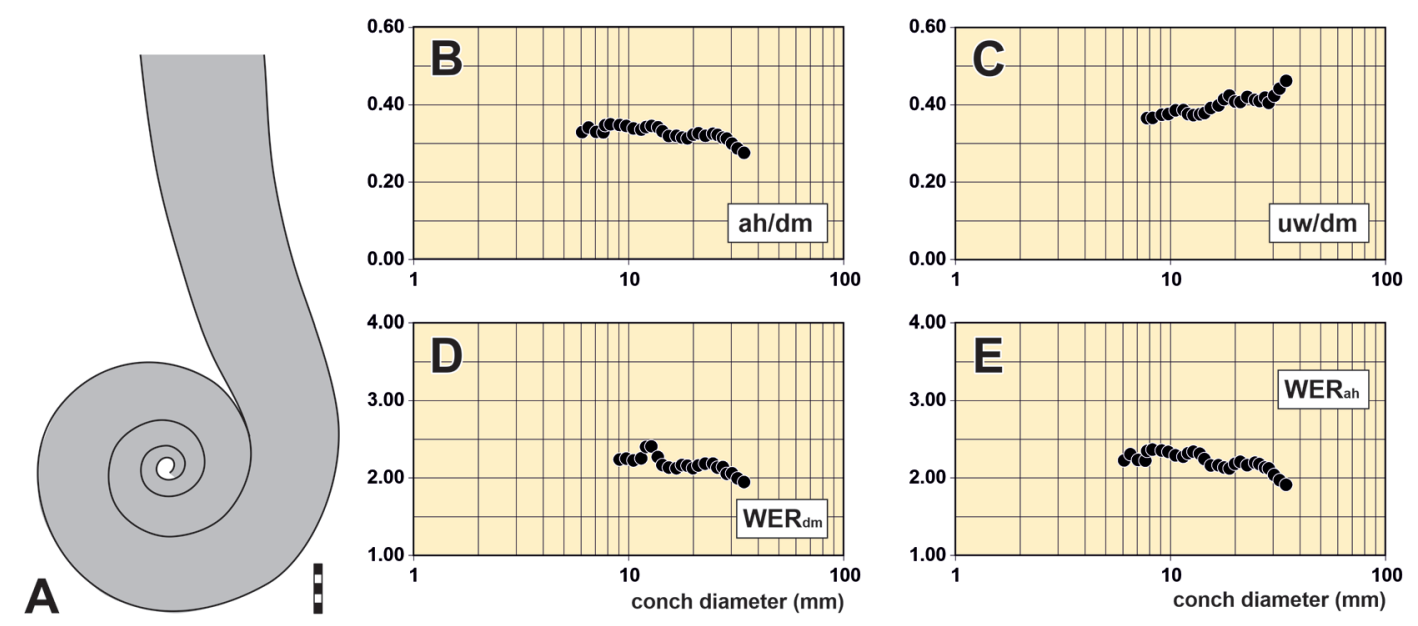

Fig. 59. Lituites clavis sp. nov. A. Outline of coiled conch part of holotype MB.C.30537. B-E. Conch proportions and coiling rates of holotype MB.C.30537. Scale bar units $=1 \mathrm{~mm}$.

Lituites dewitzi sp. nov.

urn:lsid:zoobank.org:act:8A82E920-AAD0-4EC3-A56B-B8D99B40D453

Figs 58B, 60, Tables 9-10

\section{Diagnosis}

Species of the genus Lituites with coiled part diameter of $27 \mathrm{~mm}$; tightly coiled inner volutions, last half whorl detached from the preceding; whorl expansion rate based on conch shape 2.40 and based on whorl height 2.20. Uncoiled part faintly curved, expansion angle $5^{\circ}$. Shell surface of the coiled conch with sharp, prorsiradiate growth lines and lirae, backcoiled part with wide, lamellar lirae and growth lines. Annuli very flat and widely spaced in the backcoiled part.

\section{Etymology}

After H.H. Dewitz, who published several important studies on Ordovician cephalopods during the $19^{\text {th }}$ century.

\section{Type material}

\section{Holotype}

GERMANY • Mecklenburg-Vorpommern, Boltenhagen (Gross Klütz Höved); Ordovician (Lasnamägi Regional Stage, late Darriwilian), Upper Grey Orthoceratite Limestone; MB.C.30538 (illustrated in Fig. 58B).

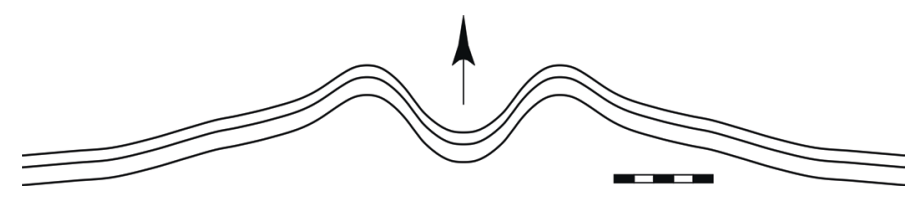

Fig. 60. Lituites dewitzi sp. nov. from the Schroeteri Limestone; lirae on the venter in holotype MB.C.30538 (Neben Coll.) from Boltenhagen near Gross Klütz Höved (Mecklenburg-Vorpommern, Germany), at $\mathrm{wh}=11 \mathrm{~mm}$. Scale bar units $=1 \mathrm{~mm}$. 


\section{Description}

Holotype MB.C.30538 (Fig. 58B) consists of the coiled part ( $\mathrm{dm}=27 \mathrm{~mm} ; 1.5$ volutions preserved, coiling of inner volutions almost tight or tight, only the last 0.5 volution detached) and the faintly curved backcoiled part (length $=68 \mathrm{~mm}$; wh $=14 \mathrm{~mm}$; EA $\sim 5^{\circ}$ ). The ornament reveals two successive stages: (1) The coiled part (except for the last $60^{\circ}$ ) shows sharp growth lines, strengthened to lirae, and annuli, which run almost straight but with a forward direction across the flank. In the ventrolateral area they bend into a shallow ventral sinus. (2) At the end of the coiled part, the narrow lirae transform into wide, lamellar lirae with distances of 0.5 to $1.2 \mathrm{~mm}$. This ornament is retained in the entire preserved backcoiled part. There are delicate growth lines between the raised lirae. Annuli are present in the coiled part and then flatten out towards the backcoiled part, where they are visible only as very flat undulations of the shell wall. In the coiled part, the lateral sinus of ornament elements is not distinctly developed; after uncoiling, it remains shallow and oblique, sloping towards the dorsum. The ventral sinus is deep and rounded with a ventral band (up to wh of $10 \mathrm{~mm}$; Fig. 60); the dorsal projection is very low.

\section{Remarks}

The type of coiling in Lituites dewitzi sp. nov. is similar to that in L. kruegeri sp. nov. described below, but the former has a much coarser shell ornament, particularly with regard to the lirae. Lituites perfectus differs from $L$. dewitzi sp. nov. in being eccentrically and openly coiled with conch diameters of up to $40 \mathrm{~mm}$; the backcoiled part in L. perfectus is nearly straight in shape with a lower expansion angle $\left(1^{\circ}-4^{\circ}\right)$. Lituites dewitzi sp. nov. stands out among the species of the genus Lituites in the prorsiradiate direction of ornament elements in the coiled part of the conch.

Lituites nebeni sp. nov.

urn:1sid:zoobank.org:act:7DBAADFC-3AC7-41C1-B0BF-894C3FE9D6FE

Figs 58C, 61-62, Tables 9-10

Lituites cf. lituus - Hardt 1953: 45, text-fig. 10.

Lituites sp. - Neben \& Krueger 1971: pl. 31 fig. 2.
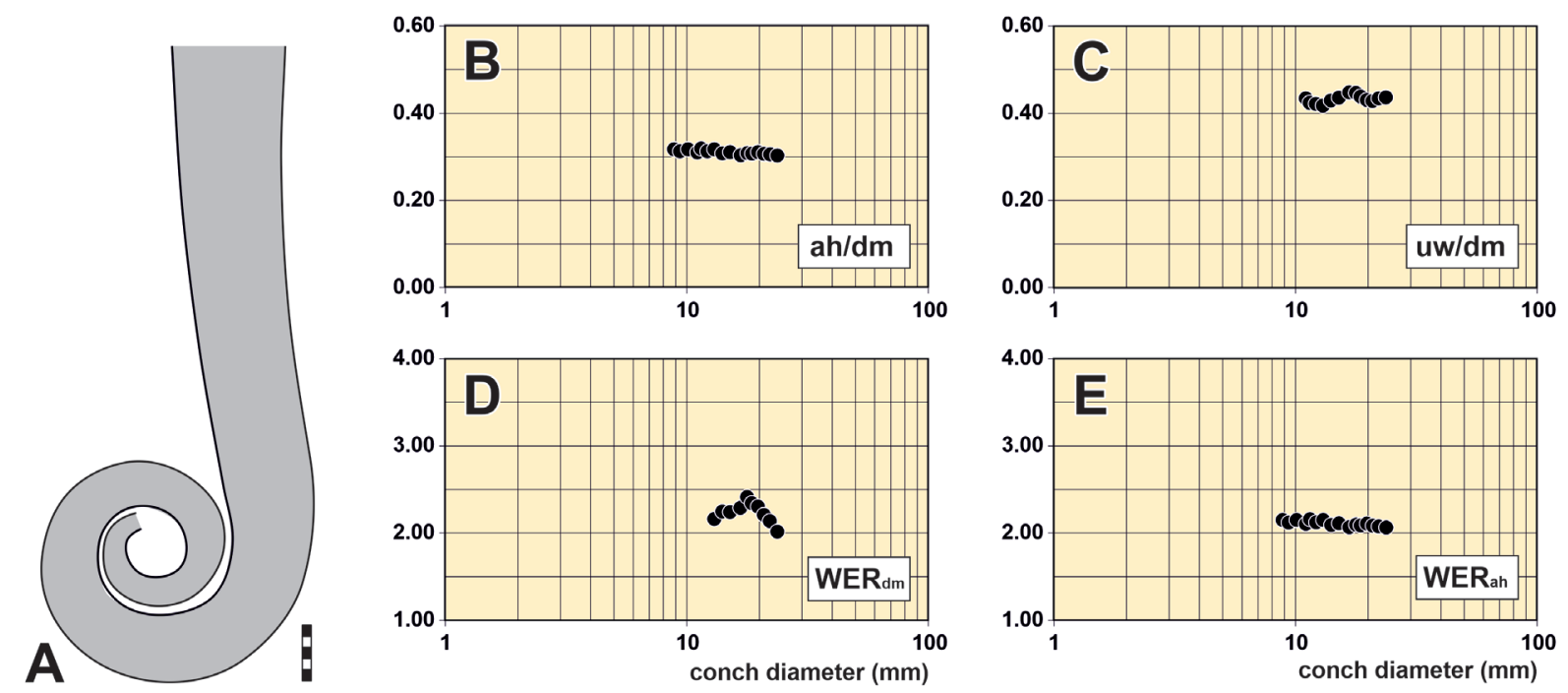

Fig. 61. Lituites nebeni sp. nov. A. Outline of coiled conch part of holotype MB.C.30541 (Neben Coll.). B-E. Conch proportions and coiling rates of holotype MB.C. MB.C.30541. Scale bar units $=1 \mathrm{~mm}$. 


\section{Diagnosis}

Species of the genus Lituites with coiled part diameter of $24 \mathrm{~mm}$; conch tightly coiled; whorl expansion rate ca 2.00. Uncoiled part weakly curved, very slender and almost tubular upon uncoiling, later reaching an expansion angle of $4^{\circ}$. Shell surface with very flat, widely spaced annuli (up to $4 \mathrm{~mm}$ apart) and sharp lirae (up to $1.2 \mathrm{~mm}$ apart).

\section{Etymology}

After the late W. Neben (1901-1971), a private collector, who collected important specimens studied herein.

\section{Type material}

\section{Holotype}

GERMANY • Brandenburg, Niederfinow; Ordovician (late Lasnamägi Regional Stage, late Darriwilian), Upper Grey Orthoceratite Limestone; Neben Coll.; MB.C.30541 (illustrated in Fig. 58C).

\section{Description}

Holotype MB.C.30541 (Fig. 58C) consists of the coiled part ( $\mathrm{dm}=24 \mathrm{~mm} ; 1.25$ whorls, tightly coiled, WER $\sim 2.00$; Fig. 61 ) and the faintly curved backcoiled part (length $=73 \mathrm{~mm}$; wh $=13 \mathrm{~mm}$ ); the backcoiled part is almost tubular after uncoiling and later reaches an expansion angle of $4^{\circ}$. The ornament of the coiled part consists of flat, widely spaced annuli (arranged up to $1.5 \mathrm{~mm}$ apart) with very fine growth lines in between; the backcoiled part possesses sharp lirae (0.5-1.2 $\mathrm{mm}$ apart), which are also visible on the internal mould, and very flat, widely spaced annuli (up to $4 \mathrm{~mm}$ apart). In the uncoiled part of the conch, the course of ornament elements is rectiradiate to slightly prorsiradiate; lateral sinus is shallow, dorsal projection is very low. The phragmocone chambers are ca 0.46 of whorl height with an increase up to 0.70 during ontogeny (Fig. 62).

\section{Remarks}

Lituites nebeni sp. nov. is somewhat similar to Trilacinoceras filix sp. nov. described below, which differs in the more delicate shell ornament, the less prominent curvature of the conch after uncoiling and a compressed whorl profile in late growth stages. The character of ornament and the circular whorl profile of the backcoiled part of the conch suggests, however, that L. nebeni sp. nov. should be classified in Lituites.

The new species is similar to $L$. anguinus but the latter has an openly coiled juvenile conch and a lower expansion angle of the uncoiled part. Lituites lituus differs from L. nebeni sp. nov. in the moderate curvature of the uncoiled part, which also has a greater expansion angle $\left(5^{\circ}-8^{\circ}\right)$; the shell ornament in L. lituus consists of prominent (instead of flat) annuli.
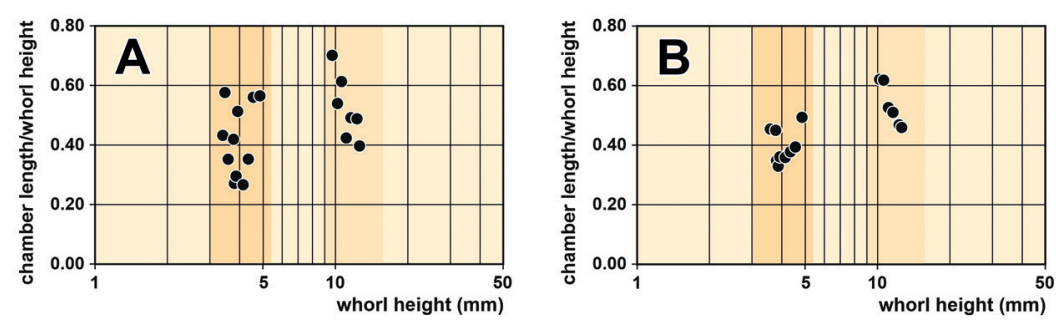

Fig. 62. Lituites nebeni sp. nov., chamber length/whorl height of holotype MB.C.30541 (Neben Coll.) from Niederfinow (Brandenburg, Germany). A. Empirical data. B. Three data point averaged. 


\section{Lituites kruegeri sp. nov. \\ urn:1sid:zoobank.org:act:52BE9C66-AE91-46CA-893A-B1749CC2980E}

Figs 63B, 64A-E, 65, Tables 9-11

Lituites sp. - Neben \& Krueger 1971: pl. 31 fig. 5.

\section{Diagnosis}

Species of the genus Lituites with coiled part $33 \mathrm{~mm}$ in diameter; inner whorls contiguous, last whorl detached, coiling widely open. Whorl expansion rate based on conch shape 2.70 , whorl expansion rate based on whorl height 2.00. Uncoiled part almost straight, tubular (expansion angle $1^{\circ}$ ). Shell surface with growth lines, sharp lirae and flat annuli. Ornament elements rectiradiate in the coiled part and prorsiradiate in the backcoiled part, closer together in the last quarter of the last whorl and further apart in distance upon uncoiling; ventral sinus deep and rounded, with a ventral band, lateral sinus very shallow or ornament elements straight across flanks.

\section{Etymology}

After Hans-Hartmut Krueger, a skilled preparator of the Museum für Naturkunde, Berlin, who masterfully prepared the holotype.

\section{Type material}

\section{Holotype}

GERMANY • Brandenburg, Werbellinsee; Ordovician (late Lasnamägi Regional Stage, late Darriwilian), Upper Grey Orthoceratite Limestone; Neben and Krueger Coll.; previously illustrated by Neben \& Krueger (1971: pl. 31 fig. 5), re-illustrated here in Fig. 63B; MB.C.30539.
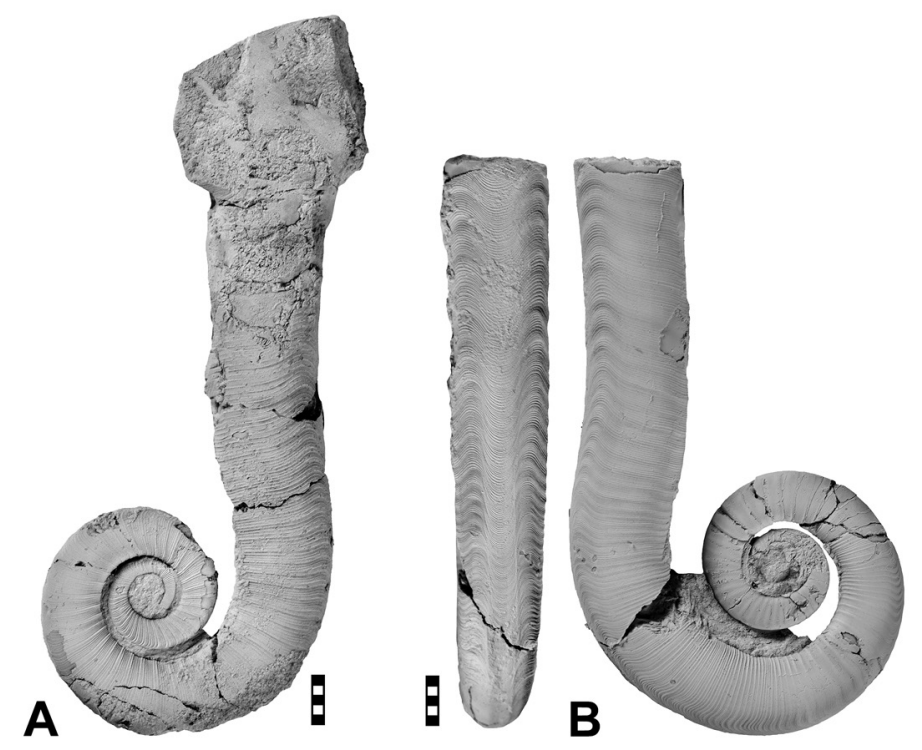

Fig. 63. Lituites kruegeri sp. nov. and L. cf. kruegeri from the Upper Grey Orthoceratite Limestone. A. L. cf. kruegeri - specimen MB.C.30540 (Neben \& Krueger Coll.) from Hohensaaten (Brandenburg); lateral view. B. L. kruegeri sp. nov. - holotype MB.C.30539 (Neben \& Krueger Coll.) from Werbellinsee (Brandenburg); previously figured by Neben \& Krueger (1971: pl. 31 fig. 5); ventral and lateral views. Scale bar units $=1 \mathrm{~mm}$. 


\section{Description}

Holotype MB.C.30539 (Fig. 63B) consists of the coiled part ( $\mathrm{dm}=33 \mathrm{~mm}$; innermost whorls are nearly in contact with the preceding, while the last whorl is detached and forms a gap $4.5 \mathrm{~mm}$ wide; coiling rates are $\mathrm{WER}_{\mathrm{dm}}=2.70$ and $\mathrm{WER}_{\mathrm{ah}}=2.00$; Fig. 64A-E) and a short part of the backcoiled part (length = $32 \mathrm{~mm}$; $w h=11 \mathrm{~mm} ; \mathrm{EA} \sim 1^{\circ}$ ). The ornament undergoes some ontogenetic change: shell is not preserved up to $16 \mathrm{~mm}$ diameter, but it appears that there are shallow annuli that are visible on the internal mould. Between 16 and $26 \mathrm{~mm}$ in diameter, the ornament consists of shallow annuli with distances of $0.5 \mathrm{~mm}$, which are particularly well-developed on the inner and outer flank. They are accompanied by sharp growth lines, which are coarsest in the area of the ventrolateral projection. The annuli weaken at $26 \mathrm{~mm}$ diameter and are replaced by raised lirae produced by rhythmically strengthened growth lines. This type of ornament continues along the last part of the coiled part of the conch ( $33 \mathrm{~mm}$ diameter). The backcoiled part and the beginning of the straight part have then sharp growth lines, which are occasionally strengthened to form lirae. This part of the conch bears incipient annuli, which are most conspicuous in the ventrolateral area as semilunate, rounded elevations. The course of the growth lines is rather stable on the coiled and the uncoiled conch, but their direction changes from rectiradiate to prorsiradiate. Generally, the growth lines extend nearly straight across the flank and form a moderately
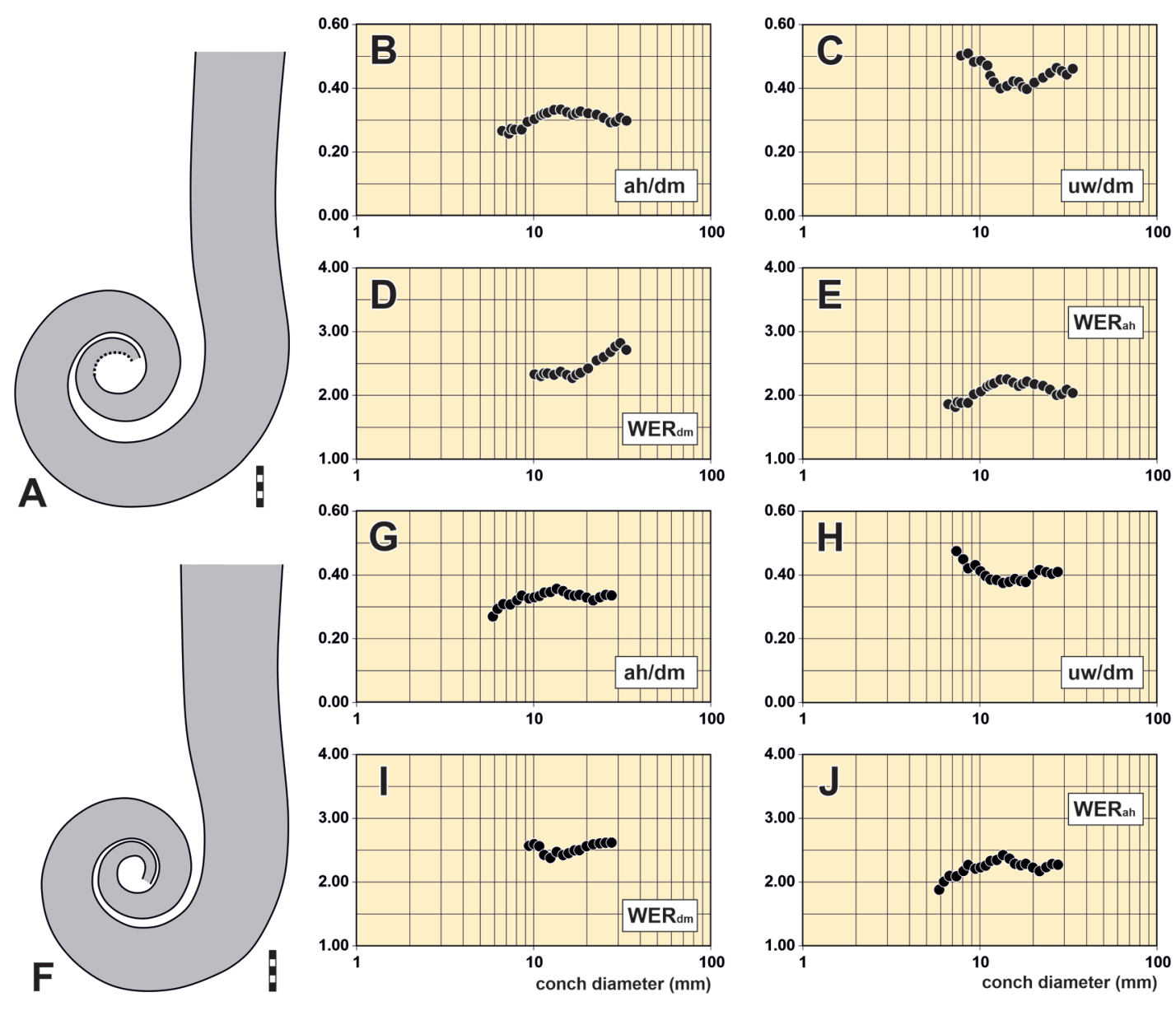

Fig. 64. Lituites kruegeri sp. nov. and Lituites cf. kruegeri. A. L. kruegeri sp. nov., outline of coiled conch part of holotype MB.C.30539. B-E. L. kruegeri sp. nov., conch proportions and coiling rates of holotype MB.C.30539. F. L. cf. kruegeri, outline of coiled conch part of specimen MB.C.30540. G-J. L. cf. kruegeri, conch proportions and coiling rates of specimen MB.C.30540. Scale bar units = $1 \mathrm{~mm}$. 


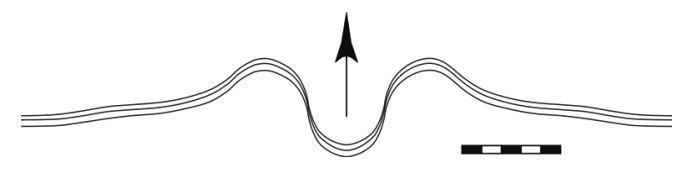

Fig. 65. Lituites kruegeri sp. nov. from the Upper Grey Orthoceratite Limestone; lirae on the venter in holotype MB.C.30539 (Neben \& Krueger Coll.) from Hohensaaten (Brandenburg, Germany), at wh = $11 \mathrm{~mm}$. Scale bar units $=1 \mathrm{~mm}$.

high ventrolateral projection. The shape of the ventral sinus changes: It is very deep and U-shaped in the coiled part and the beginning of the backcoiled part, where the growth lines touch the preceding and form a ventral band (Fig. 65). Along the backcoiled and the straight part, there occurs a shallowing of the ventral sinus. The chamber length ratio is ca 0.38 , with lower values in the coiled part apically and higher values in the backcoiled part of the specimen.

\section{Remarks}

Lituites kruegeri sp. nov. differs from L. perfectus in the more regular coiling of the conch and a more delicate shell ornament. Lituites dewitzi sp. nov. is similar in the type of coiling but has a coarser ornament and a greater expansion angle of the uncoiled part. Lituites evolutus (Late Ordovician strata of Hunan) is loosely coiled with a straight uncoiled part of the conch but some specimens have a curved uncoiled part (Fang et al. 2017: pl. 7 figs 2, 7); the whorl expansion rates are greater and the shell ornament is finer compared to L. kruegeri sp. nov.

Specimen MB.C.30540 (Figs 63A, 64F-J) might also belong to L. kruegeri sp. nov. because it has a similar geometry of the coiled part. However, the shell ornament has less prominent annuli, the ornament elements are less prorsiradiate and the interspace width is smaller. For these reasons, MB.C.30540 is classified as Lituites cf. kruegeri sp. nov.

Genus Trilacinoceras Sweet, 1958

\section{Type species}

Lituites discors Holm, 1891; designated by Sweet (1958).

\section{Species included}

Trilacinoceras aqiaense Lai \& Wang in Wang, 1981; Trilacinoceras costatum Flower, 1975; Lituites discors Holm, 1891; Trilacinoceras filix sp. nov., Trilacinoceras hunanense Lai \& Qi, 1977; Trilacinoceras kalpinense Lai \& Wang in Wang, 1981; Trilacinoceras knoefleri sp. nov., Trilacinoceras norvegicum Sweet, 1958; Trilacinoceras reubeni Flower, 1975; Trilacinoceras undulatum Flower, 1975; Trilacinoceras xinjiangense Lai \& Wang in Wang, 1981.

\section{Diagnosis}

Genus of the family Lituitidae with coiled part 18-40 mm in diameter; two to three open or tightly coiled volutions; whorl expansion rate 2.00-3.00. Whorl profile compressed throughout ontogeny. Uncoiled part straight to moderately curved, compressed, expansion angle up to $7^{\circ}$. Shell surface with narrow or prominent annulations and lirae, with conspicuously deep ventral sinus and five projections adapically, but only three projections (ventrolateral and dorsal) throughout most of the uncoiled part. Aperture with deep ventral sinus and three lappets: two incurving, tongue-shaped ventrolateral lappets and broad, low dorsal lappet; secondary dorsolateral lappet pair present in some species but this is not heralded in either 
the growth-lines, or annulations at the extreme adoral end of the body chamber. Siphuncle dorsad of centre throughout the length of phragmocone (after Sweet 1958 and Aubrechtová \& Turek 2018).

\section{Remarks}

Flower (1975) attributed three newly described species to the genus Trilacinoceras, which are supposed to differ from all other species in the combination of a slightly depressed cross section (WWI = 1.10-1.25) and suture lines with broad and shallow ventral lobe. These characters would require an emendation of the genus diagnosis provided by Sweet (1958). However, the type specimens described by Flower (1975) are rather incomplete and the preservation raises doubts about the primary origin of the peculiarities of their conch morphology. Therefore, any emendation of the original diagnosis of the genus is avoided here.

\section{Geographic and stratigraphic occurrence}

Nevada, Baltoscandia, northern Germany and Poland, Iberian Peninsula (?), central Bohemia and China; Middle to Late Ordovician.

Trilacinoceras discors (Holm, 1891)

Fig. 66A-B, Tables 12-13

Lituites discors Holm, 1891: 26, pl. 1 figs 5-7, pl. 3 figs 3-4.

Ancistroceras discors - Hyatt 1894: 508.

Trilacinoceras discors - Sweet 1958: 147, pl. 13 figs 1, 4, 6, pl. 15 fig. 5, pl. 16 figs 1, 3, 7-8, 10. Balashov 1962: pl. 7 fig. 6. - Dzik 1984: 138, text-fig. 55.12.

Lituites discors - Dzik 1984: 137, text-fig. 53b, e, pl. 40 figs 4-10.

\section{Diagnosis}

Species of the genus Trilacinoceras with coiled conch $18-33 \mathrm{~mm}$ in diameter; 2-3 coiling open or whorls contiguous. Whorl profile slightly compressed through ontogeny, commonly ventrally flattened; whorl expansion rate ca 2.70. Expansion angle of uncoiled part 3-6 $6^{\circ}$; whorl height at maturity about $23 \mathrm{~mm}$. Shell surface with annuli and/or lirae, typically fine in the coiled part (less than $1 \mathrm{~mm}$ apart) and coarser in the uncoiled part (up to ca $3 \mathrm{~mm}$ apart) of the conch. Mature aperture with very shallow and broad lateral sinuses and a short and wide ventral sinus (after Holm 1891 and Sweet 1958; modified).

\section{Type material}

Not available for study; Holm (1891) did not specify a type but he illustrated several specimens (Holm 1891: pl. 1 figs 5-7, pl. 3 figs 3-4); from Lerkaka (Island of Öland, Sweden), uppermost Red Lituites Limestone (Lasnamägi Regional Stage, late Darriwilian, Middle Ordovician).

\section{Material examined}

GERMANY - 1 spec.; Brandenburg, Niederfinow; Ordovician, Upper Red Orthoceratite Limestone; Neben and Krueger Coll.; MB.C.30552 - 1 spec.; Brandenburg, Schwedt; Ordovician, Upper Red Orthoceratite Limestone; MB.C.30553.

POLAND • 1 spec.; West Pomerania, Skowarcz (former Schönwarling), Gdańsk County; Ordovician, Upper Red Orthoceratite Limestone; MB.C.30554 - 2 specs; West Pomerania, Ustronie Morskie (former Henkengahen); Ordovician, Upper Red Orthoceratite Limestone; Krause Coll.; MB.C.11632.1, MB.C.11632.3.

COUNTRY UNKNOWN・ 1 spec.; Ordovician, Upper Red Orthoceratite Limestone; MB.C.30555. 


\section{Description}

Specimen MB.C.30552 (Fig. 66A) is a fragment of a coiled part ( $\mathrm{dm}=30 \mathrm{~mm} ; 1.3$ openly coiled whorls but the whorls get in contact just before uncoiling) and the almost straight backcoiled part (length = $60 \mathrm{~mm}$; wh $=14 \mathrm{~mm}$; EA $\sim 4^{\circ}$ ) of a conch. The whorl profile is compressed (WWI increases from $0.83-0.90$ during the backcoiled stage). The shell ornament of the coiled part consists of rhythmically strengthened growth lines $(0.10-0.15 \mathrm{~mm}$ apart), which ontogenetically transform into coarser lirae (up to $0.5 \mathrm{~mm}$ in distance); narrow annuli (ca $2.5 \mathrm{~mm}$ apart) appear after uncoiling. The ornament elements form a deep ventral sinus, a shallow to very shallow lateral sinus and a low dorsal projection; the ventral sinus is delineated by raised longitudinal lines in the coiled part, where the venter of the conch is slightly flattened. The ornament elements extend with a concavo-convex course; they are rectiradiate in the coiled part and prorsiradiate in the backcoiled part.

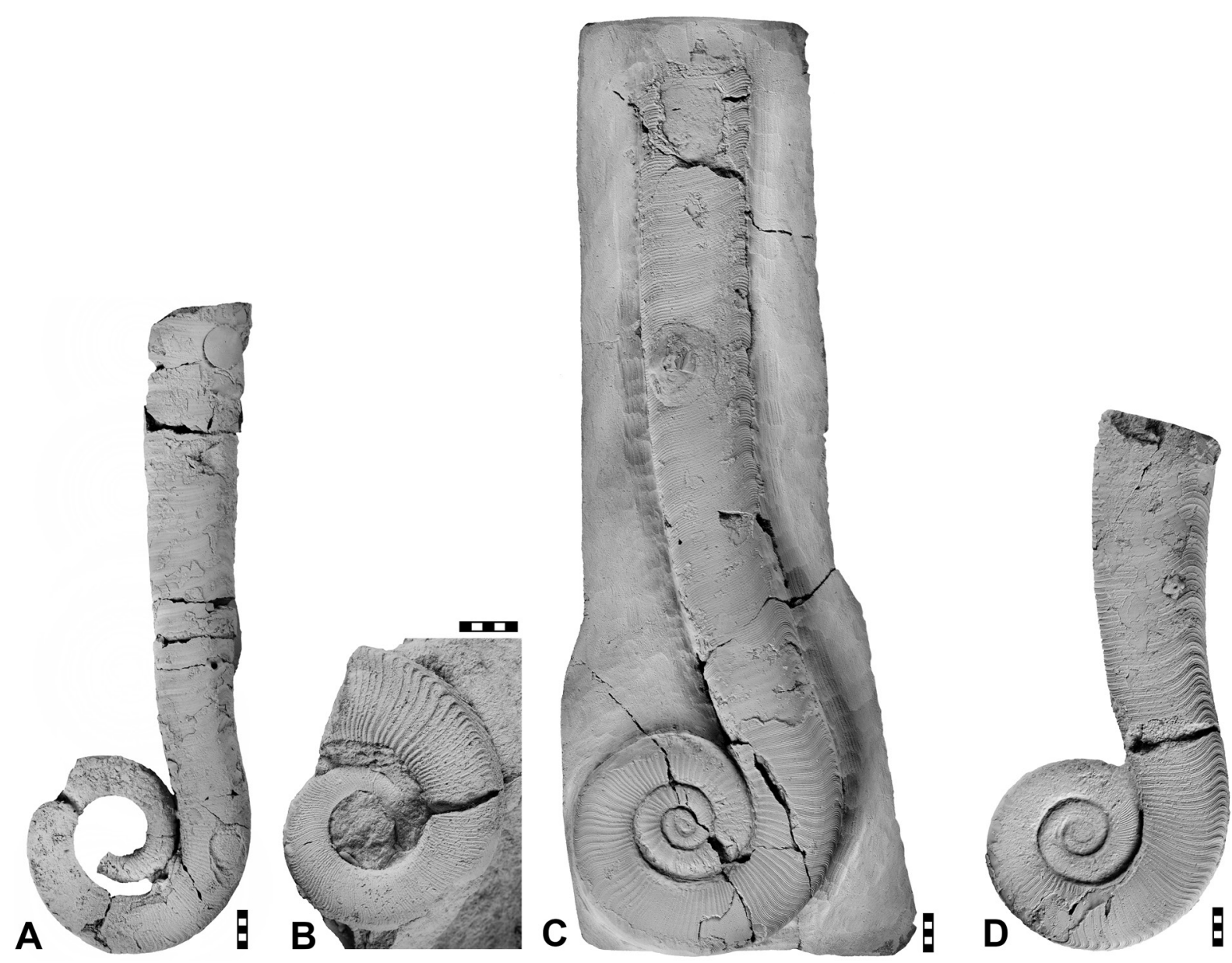

Fig. 66. Species of Trilacinoceras Sweet, 1958 from the Upper Grey Orthoceratite Limestone. A. Trilacinoceras discors (Holm, 1891), specimen MB.C.30552 (Neben \& Krueger Coll.) from Niederfinow (Brandenburg); previously figured by Neben \& Krueger(1971:pl.21 fig. 1). B. Trilacinoceras discors (Holm, 1891), specimen MB.C.30553 from Schwedt (Brandenburg). C. Trilacinoceras knoefleri sp. nov., holotype MB.C.11658 (Knöfler Coll.) from Teschendorf near Löwenberg (Brandenburg). D. Trilacinoceras knoefleri sp. nov., paratype MB.C.30559 (Krueger Coll.) from Mukran (Sassnitz, Island of Rügen) (Mecklenburg-Vorpommern). Scale bar units $=1 \mathrm{~mm}$. 
Specimen MB.C.30553 (Fig. 66B) is a fragment of a coiled conch, $25 \mathrm{~mm}$ in diameter. The shell ornament consists of growth lines, which ontogenetically transform into transverse, slightly asymmetric lirae $(0.8 \mathrm{~mm}$ distance) with fine growth lines in between them. The ornament elements form a very shallow lateral sinus and a deep ventral sinus; a low subangular ridge is present ventrally.

\section{Remarks}

Trilacinoceras discors is most similar to Lituites toernquisti (described above), but differs in the possession of a three-lappeted aperture (instead of five-lappeted) and in being usually larger in conch dimensions (Holm 1891; Sweet 1958).

\section{Geographic and stratigraphic occurrence}

Baltoscandia (in situ) and northern Germany and Poland (in erratics within Pleistocene gravels); late Aseri to Lasnamägi regional stages (late Darriwilian Middle Ordovician), possibly also early Kukruse Regional Stage (early Sandbian, early Late Ordovician).

Trilacinoceras discors has a relatively wide stratigraphic and palaeogeographic range of occurrence. It is characteristic for the early Lasnamägian Lituites discors Zone of Baltoscandia (Jaanusson \& Mutvei 1953; Jaanusson 1960; Evans et al. 2014) but occurs also in the late Lasnamägian rocks of Germany (Pleistocene erratics) and possibly in the even younger, Uhakuan, strata of peri-Gondwana (Sá \& Gutiérrez-Marco 2009; Aubrechtová \& Turek 2018).

Trilacinoceras knoefleri sp. nov. urn:1sid:zoobank.org:act:F32CE3ED-2AF5-4959-9E5D-B97ECB7AB8B4

Figs 66C-D, 67-68, Tables 12-13

\section{Diagnosis}

Species of the genus Trilacinoceras with coiled conch $38 \mathrm{~mm}$ in diameter; 2.50 to 3 tightly coiled volutions; whorl expansion rate ca 2.30 . Whorl profile compressed in coiled part, weakly compressed or almost circular early after uncoiling. Backcoiled part moderately curved, expansion angle $2-5^{\circ}$; ventral side rounded. Shell surface with growth lines and raised lirae in the coiled part; wide, flat annuli and lirae present in the backcoiled part. Ornament elements slightly irregular in distance and thickness; in the coiled part rectiradiate, in the backcoiled part prorsiradiate. Lateral sinus shallow, located between the mid-flank and the ventrolateral projection. Ventral sinus wide and rounded.

\section{Etymology}

After Hans-Rudolf Knöfler (Museum für Naturkunde, Berlin), preparator and collector of the holotype.

\section{Type material}

\section{Holotype}

GERMANY • Brandenburg, Teschendorf (Löwenberg); Ordovician (late Lasnamägi Regional Stage, late Darriwilian), Upper Grey Orthoceratite Limestone; Knöfler Coll.; MB.C.11658 (illustrated here in Fig. 66C).

\section{Paratype}

GERMANY • Mecklenburg-Vorpommern, Mukran (Sassnitz, Island of Rügen); Ordovician, Upper Grey Orthoceratite Limestone; Krueger Coll.; MB.C.30559 (illustrated in Fig. 66D). 


\section{Description}

Holotype MB.C.11658 (Fig. 66C) consists of the almost complete coiled part (dm = $38 \mathrm{~mm} ; 2.75$ tightly coiled whorls; WER $=2.20$; initial chamber does not appear to be preserved; Fig. $67 \mathrm{~A}-\mathrm{E}$ ) and a portion of the uncoiled part (length $=87 \mathrm{~mm} ; \mathrm{EA} \sim 2^{\circ}$ ). The shell ornament is preserved along the whole length of the specimen. In the first 1.5 whorls, the ornament has fine growth lines and closely spaced annuli. In the rest of the coiled part, the shell bears growth lines $(0.25-0.3 \mathrm{~mm}$ apart) and raised lirae (up to $1.7 \mathrm{~mm}$ apart) lirae. The lirae are rather irregularly developed, at conch diameters $24 \mathrm{~mm}$ and $28 \mathrm{~mm}$, they are very fine and barely visible. In the backcoiled part of the specimen, wider and lower annuli ( $3 \mathrm{~mm}$ apart) appear; lirae are up to $0.5 \mathrm{~mm}$ apart. The distance of lirae increases during ontogeny, while the distance of annuli shows a decrease (up to about $7 \mathrm{~mm} \mathrm{wh}$ ) followed by an increase (Fig. 68B-C). In the coiled part, the ornament elements are rectiradiate with a lateral sinus between the mid-flank and the ventrolateral projection, while in the backcoiled part, the ornament elements change into prorsiradiate and form a flat lateral sinus. Between coiled conch diameters 25 and $31 \mathrm{~mm}$, the ornament elements are biconvex in shape.

Paratype MB.C.30559 (Fig. 66D) consists of a coiled part $(\mathrm{dm}=30 \mathrm{~mm} ; 2.5$ tightly coiled whorls; WER $=2.40$; Fig. $67 \mathrm{~F}-\mathrm{J}$ ) and a portion of the moderately curved backcoiled part (length $=45 \mathrm{~mm}$; EA $\sim 4.5^{\circ}$ ); the whorl profile is almost circular at the beginning of uncoiling. The chamber length can
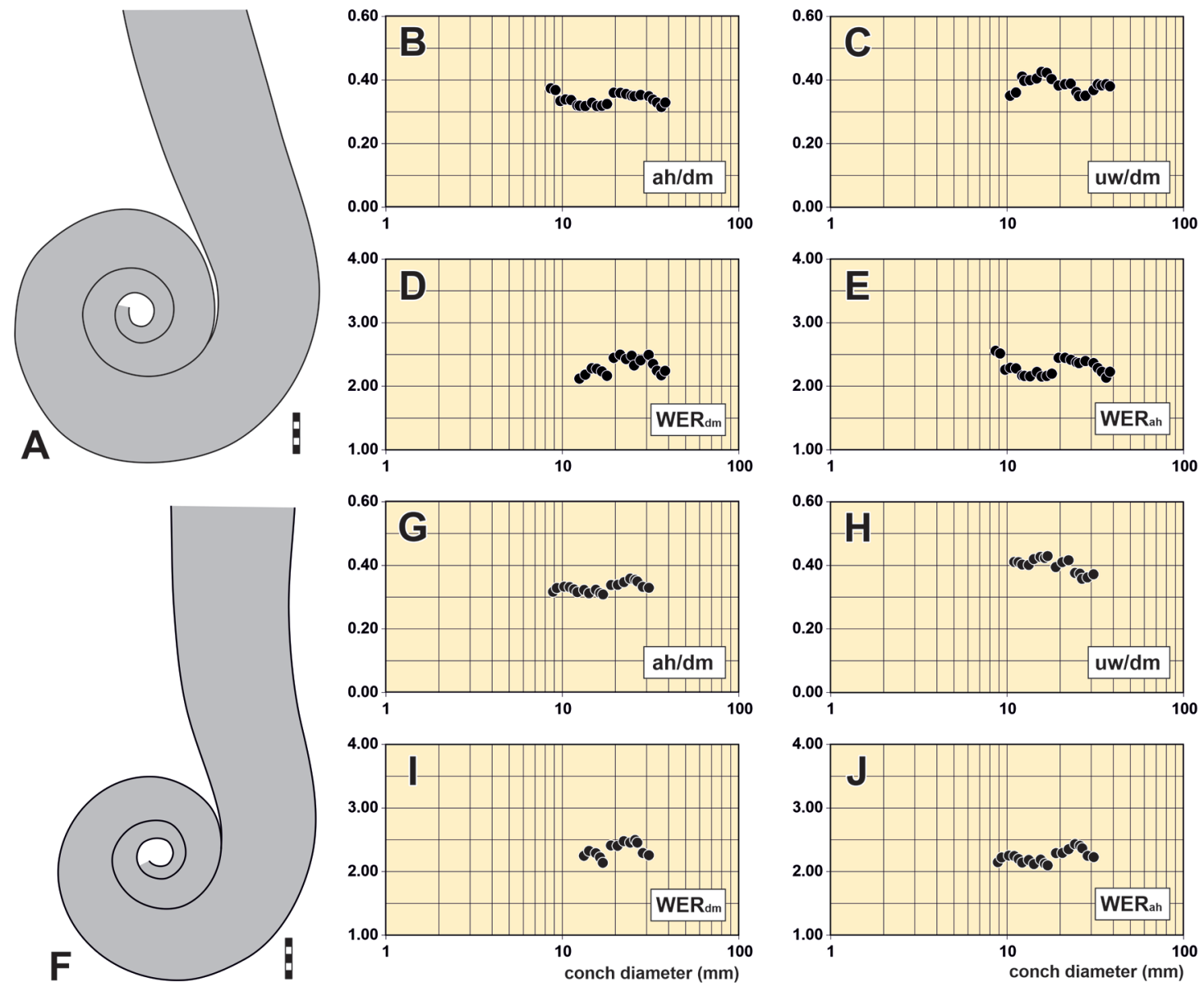

Fig. 67. Trilacinoceras knoefleri sp. nov. A. Coiling outline of holotype MB.C.11658. B-E. Conch proportions and coiling rates of holotype MB.C.11658. F. Coiling outline of paratype MB.C.30559. G-J. Conch proportions and coiling rates of paratype MB.C.30559. Scale bar units $=1 \mathrm{~mm}$. 
Table 12. Conch measurements (in mm), ratios and rates of coiled conch parts of Trilacinoceras Sweet, 1958.

\begin{tabular}{lccccccccc}
\hline taxon & catalogue $\mathbf{~ n r}$ & $\mathbf{d m}$ & $\mathbf{w h}$ & $\mathbf{u w}$ & ww & WERdm & WERah & UWI & WWI \\
\hline T. discors & MB.C.30553 & 24.8 & 8.2 & 11.4 & - & 3.14 & 2.23 & 0.46 & - \\
T. discors & MB.C.30555 & 29.0 & 10.6 & - & 26.7 & 2.48 & 2.48 & - & 0.92 \\
T. discors & MB.C.30552 & 29.6 & 9.3 & 13.9 & 24.6 & 2.19 & 2.13 & 0.47 & 0.83 \\
T. filix & MB.C.30557 & 28.0 & 8.4 & 13.4 & - & 2.47 & 2.04 & 0.48 & - \\
T. knoefleri & MB.C.11658 & 38.3 & 12.6 & 16.1 & - & 2.22 & 2.22 & 0.42 & - \\
T. knoefleri & MB.C.30559 & 29.8 & 10.6 & 13.1 & 25.3 & 2.41 & 2.41 & 0.44 & 0.85 \\
T. knoefleri & MB.C.30558 & 30.9 & 10.2 & 13.6 & - & 2.25 & 2.23 & 0.44 & - \\
T. cf. hunanense & MB.C.29655 & 36.3 & 11.4 & 15.6 & - & 2.09 & 2.13 & 0.43 & - \\
\hline
\end{tabular}

be measured near the end of the specimen, where the CLR is 0.48 . The shell ornament is preserved along the whole length of the specimen, except for the innermost whorls. In the coiled part of the conch, it consists of growth lines and more or less regularly raised lirae (up to $1 \mathrm{~mm}$ apart). After uncoiling, the lirae become wider and very flat annuli appear (ca $3 \mathrm{~mm}$ apart); the lirae are up to $1 \mathrm{~mm}$ apart. The ventral sinus of ornament elements is broad and rounded (Fig. 68A). The lateral sinus is shallow and located between the mid-flank and the ventrolateral projection. The dorsal sinus is very shallow.

\section{Remarks}

The aperture is not preserved in the specimens but they are assigned to Trilacinoceras because of the combination of a large coiled portion consisting of almost three whorls, the slowly expanding and moderately curved backcoiled conch part and ornament that changes from narrow annuli/raised lirae to wider annuli during ontogeny. Trilacinoceras knoefleri sp. nov. differs from the type species $T$. discors in the larger size and lower expansion angle. Also, the ventral sinus of the ornament elements is broader and the whorl profile in the uncoiled part of the conch is less compressed and ventrally not flattened.

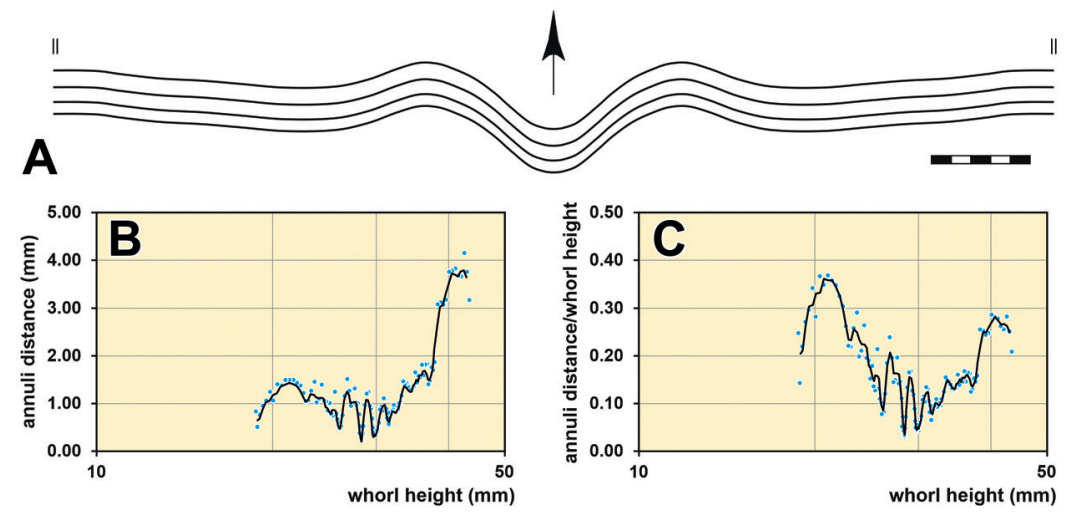

Fig. 68. Trilacinoceras knoefleri sp. nov. from the Upper Grey Orthoceratite Limestone. A. Lirae of paratype MB.C.30559 (Krueger Coll.) from Mukran (Sassnitz, Island of Rügen) (MecklenburgVorpommern), at wh $=14 \mathrm{~mm}$. B-C. Ontogenetic development of annuli distance (in $\mathrm{mm}$ ) and annuli distance/whorl height of holotype MB.C.11658 (Knöfler Coll.) from Teschendorf near Löwenberg (Brandenburg). Blue dots $=$ individual measurements, black lines $=$ three data point averaged values. Scale bar units $=1 \mathrm{~mm}$. 
Trilacinoceras knoefleri sp. nov. is very similar to $T$. cf. hunanense, which is, however, more finely ornamented along the whole conch length and has a greater expansion angle of the uncoiled part; T. hunanense possesses a straight uncoiled part of the conch.

\section{Geographic and stratigraphic occurrence}

Northern Germany (in erratics within Pleistocene gravels); late Lasnamägi Regional Stage, late Darriwilian, Middle Ordovician).

Trilacinoceras filix sp. nov. urn:1sid:zoobank.org:act:76E53596-0229-4CB3-A62F-E12F3A296FEB

Figs 69A, 70, Tables 12-13

Lituites cf. perfectus - Neben \& Krueger 1971: pl. 31 fig. 4.

Lituites sp. - Neben \& Krueger 1971: pl. 31 fig. 6.

\section{Diagnosis}

Species of Trilacinoceras with an openly coiled conch, $28 \mathrm{~mm}$ in diameter. Whorl profile slightly compressed throughout ontogeny. Backcoiled part of the conch moderately curved. Juvenile expansion angle $<1^{\circ}$, later in ontogeny up to $5^{\circ}$. Shell ornament with narrow annuli (up to $4 \mathrm{~mm}$ in distance) and fine lirae in between; rectiradiate direction with low dorsal projection, deep ventral sinus and shallow lateral sinus.

\section{Etymology}

From the Latin 'filix' = 'fern', referring to the shape of the holotype, which resembles the convoluted young leaves of some ferns.

\section{Type material}

\section{Holotype}

GERMANY - Mecklenburg-Vorpommern, Rerik (Ostsee); Ordovician (Lasnamägi Regional Stage, late Darriwilian), Upper Grey Orthoceratite Limestone; Neben and Krueger 1961 Coll.; illustrated by Neben \& Krueger (1971: pl. 31 fig. 4) and re-illustrated here in Fig. 69A; MB.C.30557.

\section{Paratype}

GERMANY • Brandenburg, Oderberg; Ordovician, Upper Grey Orthoceratite Limestone; Neben Coll.; MB.C.30556.

\section{Description}

Holotype MB.C.30557 (Fig. 69A) consists of the coiled part ( $\mathrm{dm}=28 \mathrm{~mm} ; 1.25$ openly coiled whorls; $\mathrm{WER}_{\mathrm{dm}}=2.50, \mathrm{WER}_{\mathrm{ah}}=2.00$ ) and a long portion of the almost straight backcoiled part and straight part (length $=250 \mathrm{~mm}$; EA increases from $\sim 1^{\circ}$ to $4.6^{\circ}$ ). The whorl profile is compressed (WWI increases from 0.86-0.92). It can be estimated that about half of the original body chamber is preserved. The CLR is $0.40-0.50$, without any apparent ontogenetic trend (Fig. 70). The shell ornament consists of annuli (1 to $3 \mathrm{~mm}$ in distance); fine lirae are locally preserved. The ornament elements form a deep ventral sinus and a low dorsal projection; on the flank, the elements are either straight or form a very shallow sinus.

Paratype MB.C.30556 is an incomplete, very slightly curved specimen of a body chamber with one chamber of the phragmocone preserved. The conch has similar proportions like the holotype but with better preserved shell ornament. The ornament consists of irregularly spaced annuli and lirae. The 

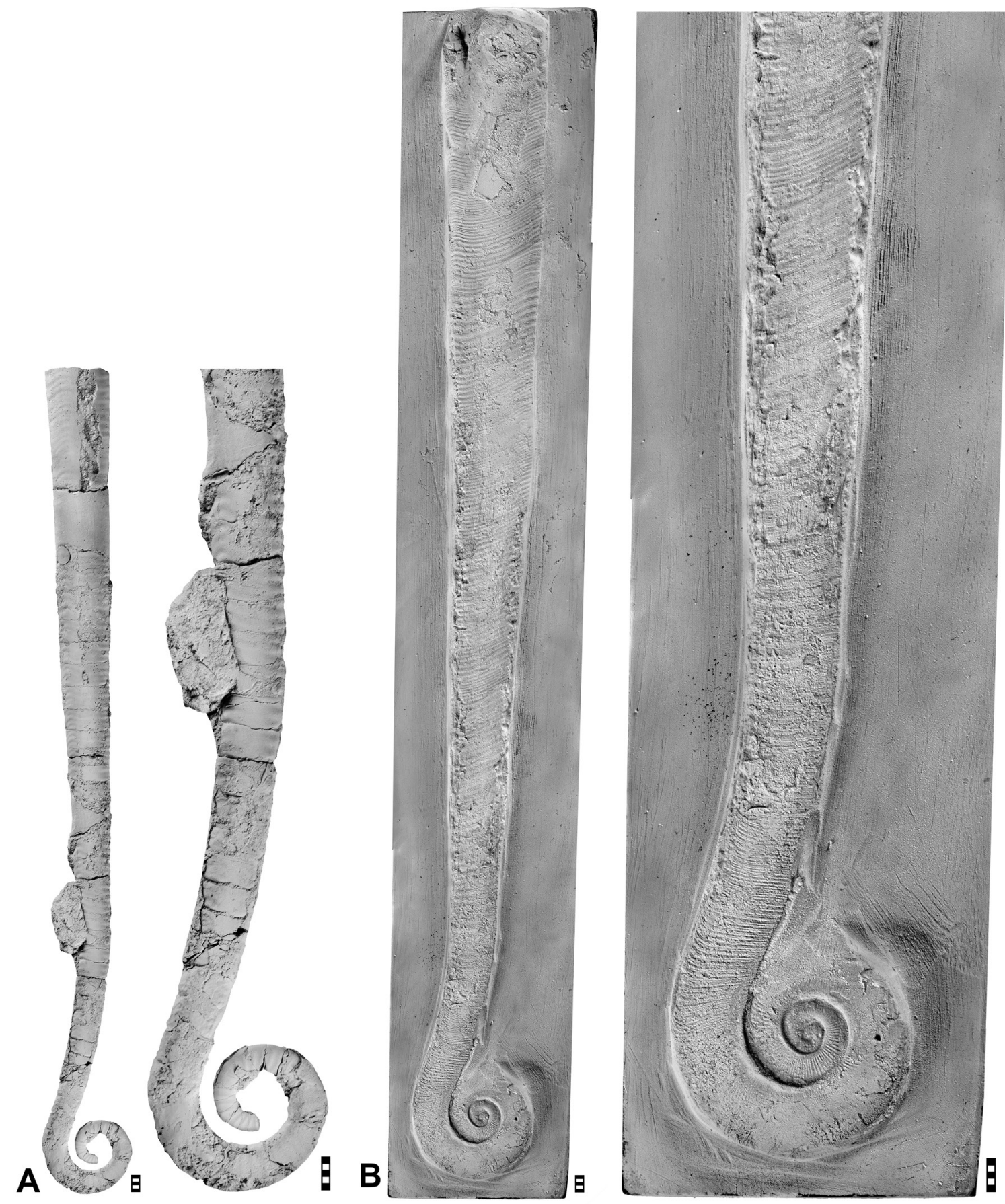

Fig. 69. Species of Trilacinoceras Sweet, 1958. A. Trilacinoceras filix sp. nov., holotype MB.C.30557 (Neben \& Krueger 1961 Coll.) from the Upper Grey Orthoceratite Limestone of Rerik (Ostsee) (Mecklenburg-Vorpommern); previously figured by Neben \& Krueger (1971: pl. 31 fig. 4). B. Trilacinoceras cf. hunanense Lai \& Qi, 1977, specimen MB.C.29655 (Bottke Coll.) from the Datianba Formation of Songtao County (Guizhou, South China). Scale bar units $=1 \mathrm{~mm}$. 
Table 13. Conch measurements (in $\mathrm{mm}$ ), and expansion rates of uncoiled conch parts of Trilacinoceras Sweet, 1958.

\begin{tabular}{lccccccc}
\hline taxon & catalogue $\mathbf{n r}$ & max. wh & max. ww & min. wh & min. ww & fragm. length & EA $\left({ }^{\circ}\right)$ \\
\hline T. discors & MB.C.30552 & 14.0 & - & 10.0 & 8.5 & 61.9 & 3.7 \\
T. filix & MB.C.30557 & 20.0 & 18.4 & 8.2 & 7.6 & 146.9 & 4.6 \\
T. filix & MB.C.30556 & 20.0 & 18.8 & 15.0 & 13.7 & 57.3 & 5.0 \\
T. knoefleri & MB.C.11658 & 15.4 & - & 13.1 & - & 65.3 & 2.0 \\
T. knoefleri & MB.C.30559 & 16.2 & 15.5 & 13.0 & 11.9 & 40.7 & 4.5 \\
T. knoefleri & MB.C.30558 & 14.6 & - & 12.1 & - & 59.7 & 2.4 \\
T. cf. hunanense & MB.C.29655 & 31.0 & - & 12.0 & - & 265.4 & 4.1 \\
\hline
\end{tabular}

annuli are more strongly approximated behind the position of the last preserved septum (ca $1 \mathrm{~mm}$ apart) and have widest distances in the mid-length of the specimen (4 mm apart). The ornament elements form a deep ventral sinus, shallow lateral sinuses and a low dorsal projection. The single preserved phragmocone chamber has CLR of 0.32 .

\section{Remarks}

The new species is assigned to the genus Trilacinoceras because the conch has a conspicuously low expansion angle and the whorl profile remains compressed even in the apertural part of the conch (max. WWI 0.92 in the holotype and 0.94 in the paratype). The species is most similar to the type species $T$. discors, in which the conch has a higher expansion angle $\left(3-6^{\circ}\right)$, particularly after uncoiling. Furthermore, the ornament is different in both species. In T. discors, narrow but prominent annuli and lirae are developed in the coiled part and wider and flatter annuli in the uncoiled part. By contrast, the holotype of T. filix sp. nov. is decorated by rather widely spaced and strong annuli (1 mm apart) in the coiled part and comparatively narrower and widely spaced annuli (up to $4 \mathrm{~mm}$ apart) towards the apertural part.

Trilacinoceras filix sp. nov. is also rather similar to Lituites nebeni sp. nov. but the latter has a circular whorl profile, a more prominent shell ornament and a stronger curvature of the backcoiled part.

\section{Geographic and stratigraphic occurrence}

Northern Germany (in erratics within Pleistocene gravels); late Lasnamägi Regional Stage, late Darriwilian, Middle Ordovician.
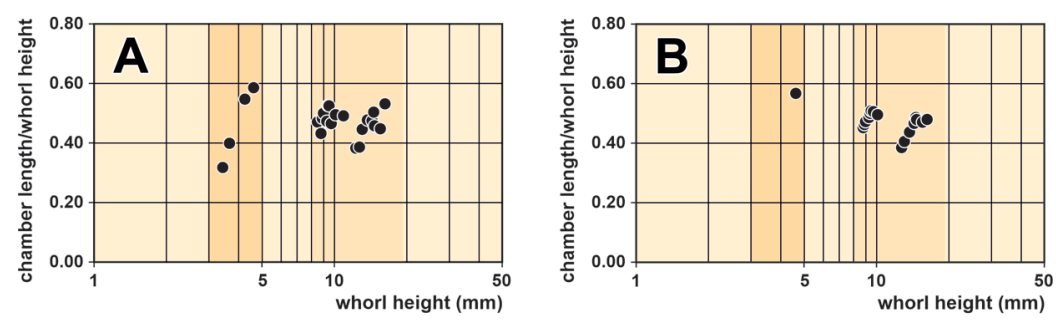

Fig. 70. Trilacinoceras filix sp. nov., chamber length/whorl height of holotype MB.C.30557 (Neben \& Krueger Coll.) from Rerik (Ostsee) (Mecklenburg-Vorpommern). A. Empirical data. B. Three data point averaged. 
Trilacinoceras cf. hunanense Lai \& Qi, 1977

Figs 69B, 71, Tables 12-13

\section{Material examined}

CHINA • 1 spec.; Guizhou, Songtao; Ordovician; Bottke Coll.; MB.C.29655.

\section{Description}

Specimen MB.C.29655 (Fig. 69B) is a $326 \mathrm{~mm}$ long conch, which is partially embedded in the surrounding dark-brown limestone. The coiled part has a diameter of $36 \mathrm{~mm}$ and consists of at least 2.25 tightly coiled volutions (initial chamber is not preserved); the whorl expansion rate is 2.10 (Fig. 71). The uncoiled part is relatively strongly curved and expands with an angle of $4^{\circ}$. Ornament is preserved along the whole length of the specimen and is slightly irregular in distance. In the coiled part, the ornament consists of growth lines and raised lirae; in inner whorls, the ornament elements are straight, later, a shallow sinus is developed ventrolaterally. In the rest of the conch, narrow annuli (up to $2.7 \mathrm{~mm}$ in distance) and lirae (up to $0.3 \mathrm{~mm}$ apart) are present; the distance and thickness of the ornament elements is irregular; the conch is slightly constricted, where the ornament elements are the finest. The ornament elements in the backcoiled part have a rectiradiate direction but towards the straight part, they become rursiradiate; a marked dorsal projection and a sinus between the mid-flank and the ventrolateral projection is developed. The adapertural part of the specimen might represent the body chamber but terminal aperture is not preserved and suture lines are not visible.

\section{Remarks}

Trilacinoceras cf. hunanense differs from $T$. hunanense in a smaller diameter of the coiled conch (36 mm vs $40 \mathrm{~mm}$ ) and a more strongly curved (vs straight) uncoiled part (Xiang Fang, pers. com.). Trilacinoceras knoefleri sp. nov. is distinguished by its smaller expansion angle and coarser, rectiradiate ornament of the backcoiled part. The rursiradiate direction of ornament elements in the straight conch part of Trilacinoceras cf. hunanense distinguishes the Chinese specimen from all specimens in the collection that come from European regions.
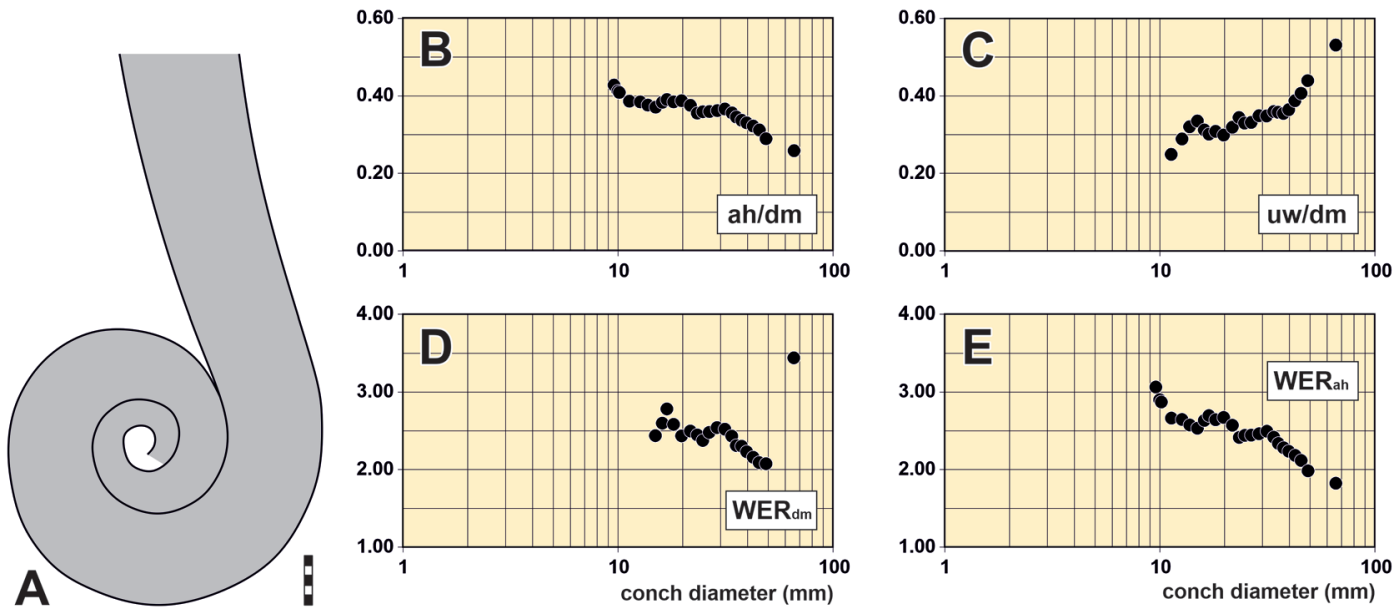

Fig. 71. Trilacinoceras ef. hunanense Lai \& Qi, 1977. A. Coiling outline of specimen MB.C.29655. B-E. Conch proportions and coiling rates of specimen MB.C.29655. Scale bar units $=1 \mathrm{~mm}$. 
Genus Cyclolituites Remelé, 1886

\section{Type species}

Lituites applanatus Remelé, 1880; by original designation.

\section{Species included}

Cyclolituites americanus Hyatt, 1894; Cyclolituites anhuiensis Qi, 1980; Lituites applanatus Remelé, 1880; Cyclolituites dazhubaensis Chen in Gao et al., 1982; Cyclolituites hubeiensis Xu \& Liu, 1977; Cyclolituites kjerulfi Sweet, 1958; Cyclolituites Lynceus Holm, 1891; Lituites Lynnensis Kjerulf, 1865; Cyclolituites trilobatus Lai \& Wang in Wang, 1981.

\section{Diagnosis}

Genus of the family Lituitidae with discoidally coiled conch, uncoiled conch part lacking. Inner whorls tightly coiled, last volution or only its apertural end detached from the preceding; umbilical window large, 2-5 mm wide; whorl expansion rate ca 3.10; increasingly prominent ventral ridge developed in apertural end of the conch. Shell surface faintly annulated or lirated. Siphuncle position subdorsal to subcentral. Aperture of mature conch five-lobed, characterised by a deep ventral sinus, a pair of asymmetric ventrolateral lappets, lateral sinuses and less pronounced dorsolateral and dorsal projections (after Sweet 1958 and Furnish \& Glenister 1964; modified).

\section{Remarks}

Cyclolituites americanus, from the early or middle Darriwilian strata of Newfoundland, differs from all other species of the genus in a significantly larger coiled conch (over $40 \mathrm{~mm}$ diameter) and in the pronounced paired grooves flanking the ventral sinus of the ornament. In both characters, C. americanus is similar to Angelinoceras latum (Dzik 1984). However, C. americanus is known so far only from a single, fragmentary specimen (Flower 1975), in which adoral part of the conch are missing, and the species is thus tentatively retained in the genus Cyclolituites.

Dzik (1984) stated that Cyclolituites applanatus, C. lynceus and C. lynnensis cannot be recognised as separate species. In fact, however, the data presented herein show that the three species can be distinguished rather easily based on their maximum conch diameters, whorl expansion rates and shell ornament (see below). Dzik (1984) stated that C. kjerulfi appears to represent apical parts belonging to some species of the genus Ancistroceras. This interpretation is not possible to validate here without the study of the type specimens of C. kjerulfi, but from descriptions of the species by Sweet (1958), it is clear that the coiled conch has an umbilical window and a ventral keel. Both features are characteristic for species of the genus Cyclolituites.

\section{Geographic and stratigraphic occurrence}

Newfoundland (Canada), Norway, Sweden, northern Germany, Anhui and Hunan (China); Middle to Late Ordovician.

\section{Cyclolituites applanatus (Remelé, 1880)}

Fig. 72

Lituites applanatus Remelé, 1880: 438.

Cyclolituites applanatus - Remelé 1886: 467; 1890: 101, pl. 1 fig. 6a-b.

Lituites applanatus - Remelé 1890: 30.

Cyclolituites applanatum - Holm 1891: 33. 
Cyclolituites applanata - Neben \& Krueger 1971: pl. 32 figs 19-20.

\section{Diagnosis}

Species of the genus Cyclolituites with tightly coiled conch, only last whorl detached near mature aperture; whorl profile compressed $(\mathrm{WWI}=0.60)$. Shell surface with narrow annuli/raised lirae, adorally $0.5-1 \mathrm{~mm}$ apart, marked ventral sinus; lateral sinus weakly developed in inner whorls of the conch, shallow and asymmetric towards the aperture.

\section{Type material}

Lectotype (designated herein)

GERMANY - Brandenburg, Eberswalde; Ordovician, Upper Grey Orthoceratite Limestone; Kgl. Forstakademie Eberswalde Coll.; illustrated by Remelé (1880: pl. 1 fig. 6; 1890: pl. 1 fig. 6), re-illustrated here in Fig. 72B; MB.C.11671.2.

\section{Additional material}

GERMANY - 1 spec.; Brandenburg, Oderberg; Ordovician, Upper Grey Orthoceratite Limestone; MB.C.30560.

\section{Description}

Lectotype MB.C.11671.2 (Fig. 72B) consists of a part of the coiled conch $(\mathrm{dm}=20 \mathrm{~mm}$; one and a half tightly coiled whorls; WWI $=0.60 ; \mathrm{WER}=2.40$ ) with an incomplete body chamber. The shell ornament consists of narrow annuli/raised lirae (up to $0.5 \mathrm{~mm}$ apart) separated by very fine growth lines. The ornament elements form a deep ventral sinus and a shallow lateral sinus. The slightly flattened venter of the last whorl is raised and separated from the flanks by subangular ridges. The last quarter of the last whorl belongs to the body chamber.

Specimen MB.C.30560 (Fig. 72A) consists of the coiled part ( $\mathrm{dm}=33 \mathrm{~mm}$; one and a half tightly coiled whorls; WWI $=0.60 ; \mathrm{WER}_{\mathrm{dm}}=3.40$ ) with an almost complete body chamber. The shell is ornamented by narrow annuli/raised lirae (up to $0.50-1 \mathrm{~mm}$ apart) and very fine growth lines in between. The
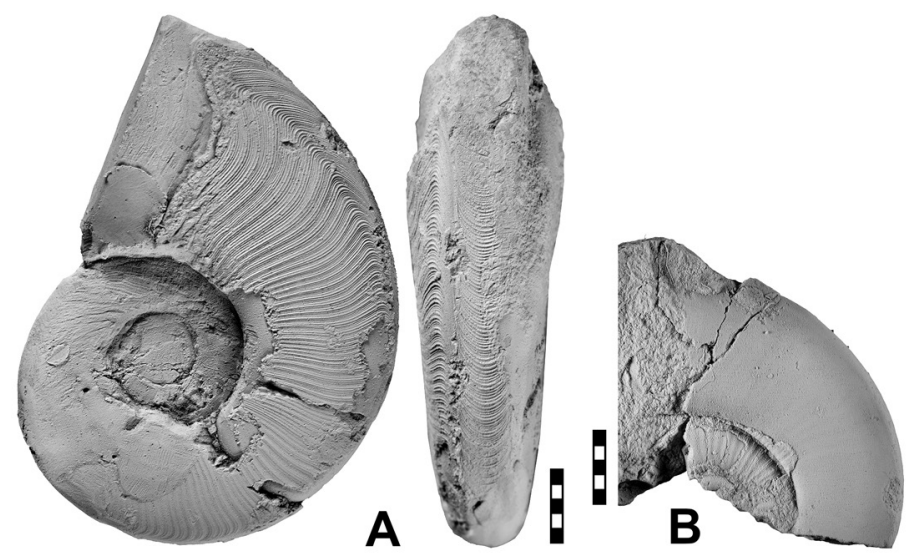

Fig. 72. Cyclolituites applanatus (Remelé, 1880) from the Upper Grey Orthoceratite Limestone. A. Specimen MB.C.30560 (Neben \& Krueger Coll.) from Oderberg (Brandenburg); previously figured by Neben \& Krueger (1971: pl. 32 figs 19-20); lateral and ventral views. B. Lectotype MB.C.11671.2 (Kgl. Forstakademie Eberswalde Coll.) from Eberswalde (Brandenburg); previously figured by Remelé (1890: pl. 1 fig. 6); lateral view. Scale bar units $=1 \mathrm{~mm}$. 
Table 14. Conch measurements (in mm), ratios and rates of coiled conchs of Cyclolituites Remelé, 1886.

\begin{tabular}{llcccccccc}
\hline taxon & catalogue $\mathbf{~ n r}$ & $\mathbf{d m}$ & $\mathbf{w h}$ & $\mathbf{u w}$ & $\mathbf{w w}$ & WERdm & WERah & UWI & WWI \\
\hline C. applanatus & MB.C.11671 & 20.3 & 7.3 & 12.0 & 8.5 & 2.44 & 2.44 & 0.42 & 0.59 \\
C. applanatus & MB.C.30560 & 32.6 & 15.0 & 19.6 & 9.8 & 3.43 & 3.43 & 0.30 & 0.60 \\
C. lynceus & MB.C.30562 & 32.4 & 13.3 & 22.7 & 12.0 & 2.94 & 2.88 & 0.37 & 0.70 \\
C. lynceus & MB.C.30561 & 37.2 & 16.1 & 26.4 & 12.6 & 3.05 & 3.11 & 0.34 & 0.71 \\
\hline
\end{tabular}

ornament elements form a ventral sinus and a lateral sinus. The lateral sinus is weakly developed and shallow, the point of its maximum backward curvature is located in the ventrolateral area. As in the lectotype, the ventral side of the last whorl is slightly raised and flattened and forms a subangular ridge. The body chamber has half the length of the last whorl.

\section{Remarks}

The lectotype of C. applanatus differs from the below described specimens of C. lynceus because it has a smaller diameter of the conch $(20 \mathrm{~mm})$, a less compressed whorl profile (WWI $=0.60)$, a lower whorl expansion rate (WER 2.40) and a coarser ornament.

Specimen MB.C.30560 (also figured by Neben \& Krueger 1971: pl. 32 figs 19-20) differs from the lectotype in the larger size and higher whorl expansion rate (WER $=3.40 \mathrm{vs} 2.40$ in the lectotype) and is thus similar to Cyclolituites lynnensis (late Middle or early Late Ordovician of Norway). It is possible, however, that the differences have the reason in an earlier ontogenetic growth stage of the lectotype. Since specimen MB.C.30560 has the same type of ornament and whorl profile shape (whorls are not impressed dorsally and lack a conspicuous keel ventrally) as the lectotype, it is retained in C. applanatus here.

\section{Geographic and stratigraphic occurrence}

Northern Germany (in erratics within Pleistocene gravels); Upper Grey Orthoceratite Limestone, late Lasnamägi Regional Stage, late Darriwilian, Middle Ordovician.

Cyclolituites lynceus Holm, 1891

Figs $73-74$

Cyclolituites Lynceus Holm, 1891: 33, pl. 1 figs 8-9.

Cyclolituites lynceus - Sweet 1958: 21. — Neben \& Krueger 1971: pl. 32 figs 17-18.

Cyclolituites lycnus - Flower 1975: 161.

\section{Diagnosis}

Species of the genus Cyclolituites with conch diameters around $35 \mathrm{~mm}$; tight coiling with only the apertural part of the body chamber detached from preceding volutions; whorl expansion rate ca 3.00; whorl profile compressed $(\mathrm{WWI}=0.70)$. Shell surface with fine growth lines and raised pairs of lirae up to $0.4 \mathrm{~mm}$ apart.

\section{Type material}

Not available for study; Holm (1891) did not specify a type but illustrated one specimen (Holm 1891: pl. 1 figs 8-9), which is reproduced here in Fig. 73C; it comes from Lerkaka (Island of Öland, Sweden), 
Folkeslunda Limestone (Upper Grey Orthoceratite Limestone, late Lasnamägi Regional Stage, late Darriwilian, Middle Ordovician).

\section{Material examined}

GERMANY • 1 spec.; Brandenburg, Oderberg; Ordovician; Neben and Krueger Coll.; MB.C.30561 - 1 spec.; Mecklenburg-Vorpommern, Boltenhagen (Gross Klütz Höved); Ordovician, Upper Grey Orthoceratite Limestone; Neben and Krueger 1962 Coll.; MB.C.30562.

\section{Description}

Specimen MB.C.30562 (Fig. 73B) is an almost complete, coiled conch with $32 \mathrm{~mm}$ diameter and consists nearly two tightly coiled whorls (WWI $=0.70 ; \mathrm{WER}=2.90$; Fig. 74B-F), of which only the second half of the last whorl is detached from the preceding. The umbilical window is $4 \mathrm{~mm}$ wide. 135 degrees of the last whorl belongs to the body chamber. An increasingly pronounced ridge is raised on the venter at the apertural end of the specimen. The shell ornament is preserved only in the inner whorls and consists of raised pairs of lirae (up to $0.4 \mathrm{~mm}$ in distance) and very fine growth lines. The aperture is partly preserved; it has a deep ventral sinus, elongated ventrolateral lappets and a rather shallow lateral sinus (dorsal edge of the aperture is not preserved). The chamber length varies between CLR $=0.20$ and 0.30 .

Specimen MB.C.30561 (Fig. 73A) is an almost complete, coiled conch $(\mathrm{dm}=37 \mathrm{~mm}$, nearly two tightly coiled whorls with only the second half of the last whorl is detached; the umbilical window $5.3 \mathrm{~mm}$ wide; WWI $=0.71$; WER $=3.10$; Fig. $74 \mathrm{~A}, \mathrm{C}-\mathrm{F}$ ); 135 degrees of the last whorl belong to the body chamber. The shell ornament is preserved only locally and consists of slightly irregularly spaced, raised lirae (up to $0.2 \mathrm{~mm}$ in distance) and very fine growth lines in between; the lirae leave imprints on the internal mould. The aperture is incomplete, only a fragment of one ventrolateral lappet is preserved.

\section{Remarks}

The two specimens under study are from the Neben \& Krueger collection and one of them, MB.C.30562, was previously figured by Neben \& Krueger (1971: pl. 32 figs 17-18). Both specimens closely resemble
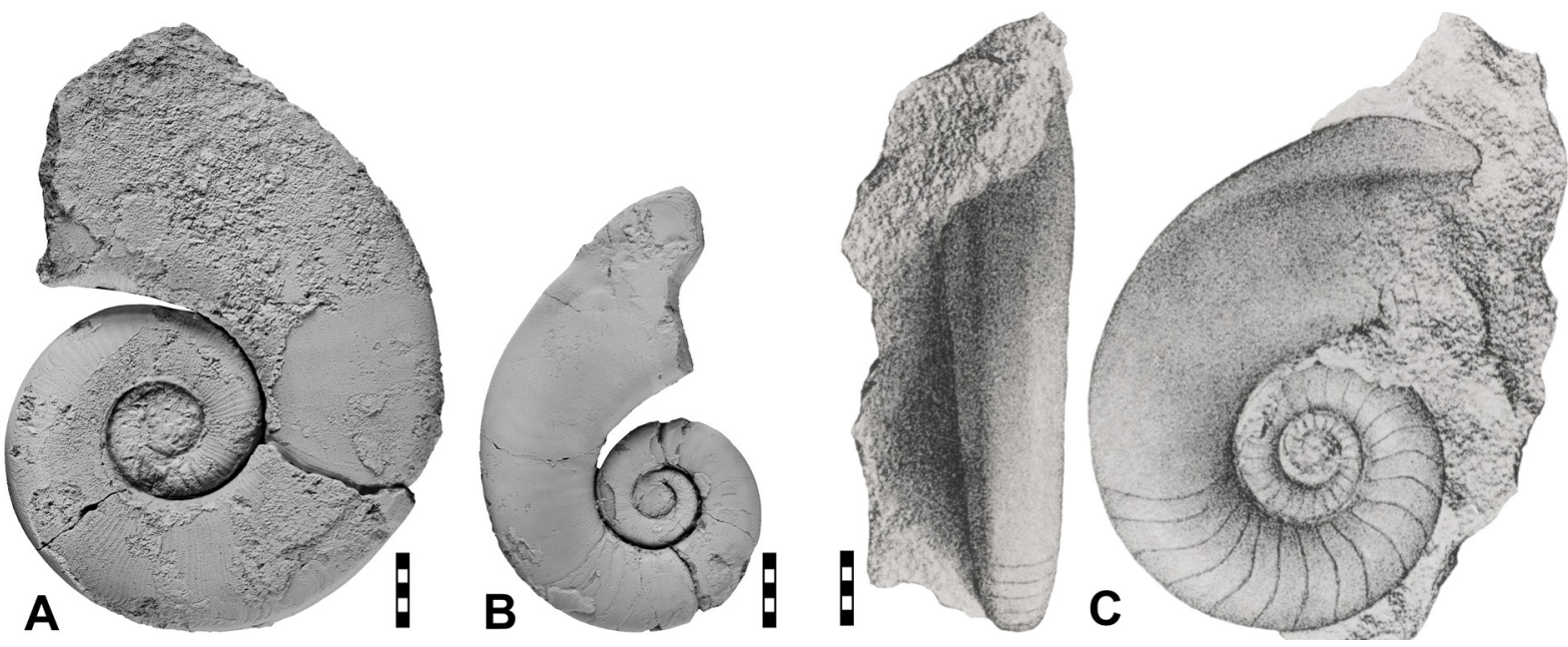

Fig. 73. Cyclolituites lynceus Holm, 1891. A. Specimen MB.C.30561 (Neben \& Krueger Coll.) from Oderberg (Brandenburg). B. Specimen MB.C.30562 (Neben \& Krueger 1962 Coll.) from Boltenhagen, Groß Klütz (Mecklenburg); previously figured by Neben \& Krueger (1971: pl. 32 figs 17-18). C. Reproduction of the illustration by Holm (1891: pl. 1 figs 8-9). Scale bar units $=1 \mathrm{~mm}$. 
Table 15. Siphuncular diameter ratio (SDR) and siphuncular distance ratio (SPR) at their corresponding whorl height in specimens of Cyclolituites Remelé, 1886.

\begin{tabular}{llcccc}
\hline taxon & catalogue $\mathbf{n r}$ & wh & SDR & wh & SPR \\
\hline C. applanatus & MB.C.11671 & 6.0 & 0.25 & 6.0 & 0.08 \\
C. lynceus & MB.C.30561 & 11.2 & 0.41 & 11.2 & 0.09 \\
\hline
\end{tabular}

the lectotype of Cyclolituites lynceus described by Holm (1891: pl. 1 figs 8-9) and are thus confidently assigned to this species. Only specimen MB.C.30561 is slightly more compressed.

In contrast to Cyclolituites applanatus, the species $C$. lynceus has a larger diameter of the conch (ca $35 \mathrm{~mm}$ ), a more compressed whorl profile (WWI $=0.70$ ), a higher whorl expansion rate (WER ca 3.00) and a finer ornament. Cyclolituites lynnensis is smaller (conch diameter around $28 \mathrm{~mm}$ ) than C. lynceus and has a coarser ornament. Cyclolituites kjerulfi differs from the other species of Cyclolituites in the smaller in diameter $(20 \mathrm{~mm})$; it uncoils much earlier (almost the whole last whorl is detached), has a narrower umbilical window and a much higher coiling rate $($ WER $=4.00-5.00)$.

\section{Geographic and stratigraphic occurrence}

Sweden (in situ) and northern Germany (in erratics within Pleistocene gravels); late Lasnamägi Regional Stage (late Darriwilian, Middle Ordovician).

\section{Discussion}

Cephalopods of the order Lituitida are among the most distinctive components of Ordovician fossil assemblages, especially from Northern Europe and China. At the same time, however, they are also one of those cephalopod groups where the clear identification and delimitation of species is a challenge. Most taxa were already described in the $19^{\text {th }}$ century (e.g., Boll 1857; Angelin 1880; Dewitz 1880; Remelé 1880, 1882, 1890; Holm 1891; Hyatt 1894), but thereafter research interest declined and only
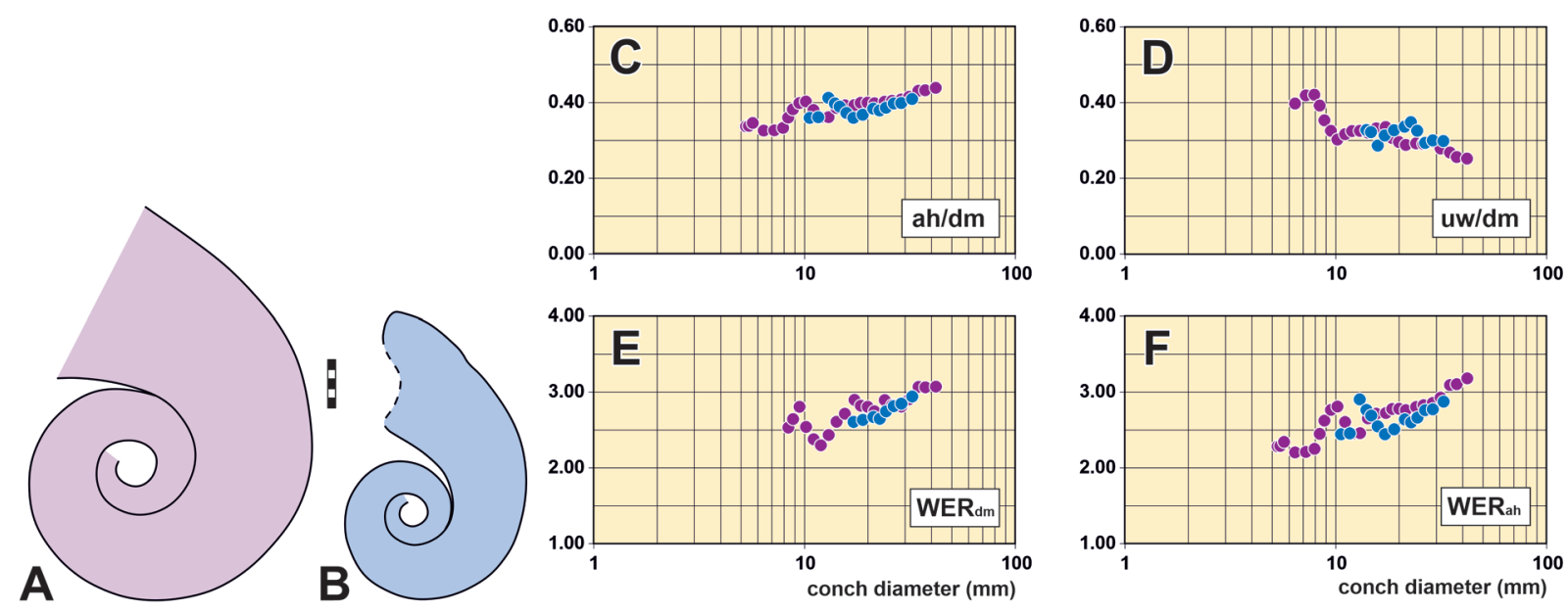

Fig. 74. Cyclolituites lynceus Holm, 1891. A. Coiling outline of specimen MB.C.30561. B. Coiling outline of specimen MB.C.30562. C-F. Conch proportions and coiling rates of the specimens MB.C.30561 and MB.C.30562. Scale bar units $=1 \mathrm{~mm}$. 
a few studies have dealt with the Baltoscandian lituitids in more detail during the $20^{\text {th }}$ and $21^{\text {st }}$ centuries (Foerste 1930; Balashov 1953; Sweet 1958; Furnish \& Glenister 1964; Dzik 1984; King 1990, 1999; Aubrechtová \& Meidla 2020; Fang et al. 2021). The insufficient knowledge of the type material and the extensive lack of detailed analyses of lituitid morphology and its changes in ontogeny have led to the fact that the classification of the Lituitida is unresolved; many taxa are only ambiguously delimited.

In this project, we studied a collection of the Baltoscandian Lituitida from Darriwilian (Middle Ordovician) erratics in Pleistocene glacio-fluvial sediments in Germany, Poland and the Kaliningrad Region of Russia and also specimens from in-situ limestones from Sweden (including the Island of Öland), Estonia and Norway. One additional specimen from the Datianba Formation (Middle or Late Ordovician) of the Songtao County (Guizhou, South China) was identified within the collection and added to the study because of its exceptionally complete preservation.

The studied material includes type specimens of several taxa, as well as later collected but unpublished material. This allowed the re-description of several poorly known and/or vaguely defined species, including Lituites lituus and L. perfectus. These two taxa were historically the first named lituitid species, but the lack of accurate descriptions as well as information on the type material made their subsequent use in the scientific literature inconsistent. Therefore, neotypes for these two species are proposed here. In addition, the following species are newly introduced: Holmiceras havelense sp. nov., Lituites baculus sp. nov., L. bottkei sp. nov., L. clavis sp. nov., L. dewitzi sp. nov., L. kruegeri sp. nov., L. nebeni sp. nov., Rhynchorthoceras kranepuhlense sp. nov., $R$. rugium sp. nov., Trilacinoceras filix sp. nov. and T. knoefleri sp. nov.

The new results update and clarify the classification and stratigraphic occurrence of lituitid cephalopods. To facilitate the taxa definition, we investigated the ontogenetic changes in coiling parameters, chamber length and ornament. Such an approach has previously proven effective in coiled cephalopods, particularly ammonoids (e.g., Klug et al. 2015 and references therein) but has been used rather rarely for early Palaeozoic nautiloid and orthoceratoid cephalopods.

\section{Acknowledgements}

We thank the curators Andreas Abele and Heike Straebelow (Museum für Naturkunde, Berlin) for their assistance, enthusiasm and company during the study in the collections of the MfN and support during the disruptions caused by COVID-19 restrictions. Xiang Fang (Nanjing Institute of Geology and Palaeontology, China) is thanked for providing missing literature on Chinese lituitid species and for helpful discussions regarding taxonomy. We are grateful to Marcela Cichowolski (University of Buenos Aires, Argentina) and an anonymous reviewer for their helpful comments and suggestions. We also thank Luca Voß (Museum für Naturkunde, Berlin) for the photography of most of the studied specimens.

\section{Funding}

MA: Deutscher Akademischer Austauschdienst (German Academic Exchange Service, DAAD), Museum für Naturkunde Berlin (Innovation Fund), Erasmus+ Programme, Faculty of Science of the Charles University (UNCE/SCI/006), Research Plan of the Institute of Geology, Czech Academy of Sciences (RVO67985831).

\section{References}

Aceñolaza F.G., Durand F.R. \& Taddei R.D. 1977. Nautiloideos ordovícicos de la Precordillera argentina: fauna de Huaco, provincia de San Juan. Acta Geológica Lilloana 13: 219-244.

Ainsaar L., Meidla T., Tinn O., Martma T. \& Dronov A. 2007. Darriwilian (Middle Ordovician) carbon isotope stratigraphy in Baltoscandia. Acta Palaeontologica Sinica 46: 1-8. 
Ainsaar L., Kaljo D., Martma T., Meidla T., Männik P., Nõlvak J. \& Tinn O. 2010. Middle and Upper Ordovician carbon isotope chemostratigraphy in Baltoscandia: a correlation standard and clues to environmental history. Palaeogeography, Palaeoclimatology, Palaeoecology 294: 189-201.

https://doi.org/10.1016/j.palaeo.2010.01.003

Angelin N.P. 1880. Fragmenta silurica e dono Caroli Henrici Wegelin: Opus studio Nicolai Petri Angelin inchoatum jussu et impensis Academiae regiae scientiarum suecicae edendum curavit G. Lindström. Samson \& Wallin, Stockholm [Holmiae]. https://doi.org/10.5962/bhl.title.63278

Aubrechtová M. \& Meidla T. 2020. Lituitid cephalopods from the upper Darriwilian and basal Sandbian (Middle-Upper Ordovician) of Estonia. GFF 142 (4): 267-296.

https://doi.org/10.1080/11035897.2020.1762723

Aubrechtová M. \& Turek V. 2018. Lituitid cephalopods from the Middle Ordovician of Bohemia and their paleobiogeographic affinities. Bulletin of Geosciences 93: 401-417.

https://doi.org/10.3140/bull.geosci.1707

Balashov Z.G. 1953. Stratigraphic distribution of nautiloids during the pre-Baltic Ordovician. Trudy vsesojuznogo neftjanogo nauchno-issledovatélskogo geologo-razvedochnogo instituta (VNIGRI) 78: 197-216.

Balashov Z.G. 1962. Otryad Tarphyceratida. In: Orlov Y.A. (ed.) Osnovy Paleontologii, MollyuskiGolovonogie 1: 77-82. Akademiya Nauk SSSR, Moskva.

Bergström S.M. 2007a. Middle and Upper Ordovician conodonts from the Fågelsång GSSP, Scania, southern Sweden. GFF 129 (2): 77-82. https://doi.org/10.1080/11035890701292077

Bergström S.M. 2007b. The Ordovician conodont biostratigraphy in the Siljan region, southcentral Sweden: a brief review of an international reference standard. In: Ebbestad J.O.R, Wickström L.M. \& Högström A.E.S. (eds) WOGOGOB 2007. Field Guide and Abstracts. Sveriges geologiska undersökning, Rapporter och Meddelande 128: 26-41.

Bergström S.M. \& Löfgren A. 2008. The base of the global Dapingian Stage (Ordovician) in Baltoscandia: conodonts, graptolites and unconformities. Earth and Environmental Science Transactions of the Royal Society of Edinburgh 99: 189-212. https://doi.org/10.1017/S1755691009008081

Bergström S.M., Chen X., Gutiérrez-Marco J.C. \& Dronov A. 2009. The new chronostratigraphic classification of the Ordovician System and its relations to major regional series and stages and to $\delta^{13} \mathrm{C}$ chemostratigraphy. Lethaia 42: 97-107. https://doi.org/10.1111/j.1502-3931.2008.00136.x

Bergström J., Pärnaste H. \& Zhiyi Z. 2013. Trilobites and biofacies in the Early-Middle Ordovician of Baltica and a brief comparison with the Yangtze Plate. Estonian Journal of Earth Sciences 62: 205-230. https://doi.org/10.3176/earth.2013.16

Bergström S.M., Saltzman M.R., Leslie S.A., Ferretti A. \& Young S.A. 2015. Trans-Atlantic Application of the Baltic Middle and Upper Ordovician Carbon Isotope Zonation. Estonian Journal of Earth Sciences 64: 8-12. https://doi.org/10.3176/earth.2015.02

Boll E. 1857. Beitrag zur Kenntnis der silurischen Cephalopoden im norddeutschen Diluvium und den anstehenden Lagern Schwedens. Archiv des Vereins der Freunde der Naturgeschichte in Mecklenburg 11: 58-95.

Breyn J.P. 1732. Dissertatio Physica de Polythalamiis, nova Testaceorum classe, cui qucedam proemittuntur de Methodo Testacea in Classes et Genera distribuendi. Huic adiictur Commentatiuncula de Belemnitis Prussicis; tandemque Schediasma de Echinis methodice disponendis. Cornelium a Beughem, Danzig [Gedani]. https://doi.org/10.5962/bhl.title.9112 
Chen T.E. 1987. Ordovician nautiloids from Xainza, northern Xizang. Bulletin of Nanjing Institute of Geology and Palaeontology, Academia Sinica 11: 133-191.

Cocks L.R.M. \& Torsvik T.H. 2005. Baltica from the late Precambrian to mid-Palaeozoic times: the gain and loss of a terrane's identity. Earth-Science Reviews 72: 39-66.

https://doi.org/10.1016/j.earscirev.2005.04.001

de Montfort P.D. 1808. Conchyliologie systématique, et classification méthodique des coquilles: offrant leurs figures, leur arrangement générique, leurs descriptions caractéristiques, leurs noms, ainsi que leur synonymie en plusieurs langues. F. Schoell, Paris. https://doi.org/10.5962/bhl.title.10571

Dewitz H. 1880. Ueber einige ostpreussische Silurcephalopoden. Zeitschrift der deutschen geologischen Gesellschaft 32: 371-393.

Dronov A. \& Holmer L. 1999. Depositional sequences in the Ordovician of Baltoscandia. Acta Universitatis Carolinea - Geologica 43: 133-136.

Dronov A. \& Rozhnov S. 2007. Climatic changes in the Baltoscandian basin during the Ordovician: sedimentological and palaeontological aspects. Acta Palaeontologica Sinica 46: 108-113.

Dronov A., Ainsaar L., Kaljo D., Meidla T., Saadre T. \& Einasto R. 2011. Ordovician of Baltoscandia: facies, sequences and sea-level changes. In: Gutiérrez-Marco J.C., Rábano I \& García-Bellido D. (eds) Ordovician of the World. Cuadernos del Museo Geominero 14: 143-150. Instituto Geológico y Minero de España, Madrid.

Dzik J. 1984. Phylogeny of the Nautiloidea. Palaeontologia Polonica 45: 1-219.

Dzik J. \& Kiselev G.N. 1995. The Baltic nautiloids Cyrtoceras ellipticum Lossen 1860, C. priscum Eichwald 1861, and Orthoceras damesi Krause 1877. Paläontologische Zeitschrift 69: 61-71. https://doi.org/10.1007/BF02985974

Ebbestad J.O.R. \& Högström A.E.S. 2007. Ordovician of the Siljan district, Sweden. In: Ebbestad J.O.R, Wickström L.M. \& Högström A.E.S. (eds) WOGOGOB 2007. Field Guide and Abstracts. Sveriges geologiska undersökning, Rapporter och Meddelande 128: 26-41.

Ekdale A.A. \& Bromley R.G. 2001. Bioerosional innovation for living in carbonate hardgrounds in the Early Ordovician of Sweden. Lethaia 34: 1-12. https://doi.org/10.1080/002411601300068152

Evans D.H., King A.H., Histon K. \& Cichowolski M. 2014. Nautiloid cephalopods - a review of their use and potential in biostratigraphy. Denisia 32: 7-22.

Fang X., Chen T., Zhang Y. \& Zhang Y. 2017. Lituitidae nautiloids from the Datianba Formation (Uppermost Darriwilian to Sandbian, Ordovician) in western Hunan Province and its ontogenical study. Acta Palaeontologica Sinica 56: 331-346.

Fang X., Pohle A., Kröger B., Aubrechtová M., Burrett C., Zhang Y. \& Zhang Y. 2021. Phylogeny of Middle-Late Ordovician lituitid cephalopods based on cladistic analysis. Journal of Systematic Palaeontology 19 (9): 633-650. https://doi.org/10.1080/14772019.2021.1944354

Flower R.H. 1955. Cameral deposits in orthoconic nautiloids. Geological Magazine 92: 89-103. https://doi.org/10.1017/S0016756800063408

Flower R.H. 1964. Nautiloid shell morphology. New Mexico Institute of Mining and Technology, State Bureau of Mines and Mineral Resources, Memoir 13: 1-77.

Flower R.H. 1968. Some Additional Whiterock Cephalopoda. New Mexico Institute of Mining and Technology, State Bureau of Mines and Mineral Resources, Memoir 19 (2): 17-55. 
Flower R.H. 1975. American Lituitidae (Cephalopoda). Bulletins of American Paleontology 67: 139173.

Foerste A.F. 1930. Three studies of cephalopods. Denison University Bulletin, Journal of the Scientific Laboratories 23: 265-381.

Foerste A.F. 1932. The cephalopod genera Cyrtendoceras and Oelandoceras. The Ohio Journal of Science 32 (3): 163-172.

Furnish W.M. \& Glenister B.F. 1964. Nautiloidea-Tarphycerida. In: Moore R.C. (ed.) Treatise on Invertebrate Paleontology: K343-K368. The Geological Survey of America and The University of Kansas Press, Lawrence, KS.

Hardt H. 1953. Schätze im norddeutschen Sand: eine geologische Betrachtung. Aufbau-Verlag. Berlin.

Hisinger W. 1837. Lethaea Svecica seu Petrificata Sveciae, iconibus et characteribus illustrata: cum duobus Supplementis. Norstedt, Stockholm.

Holm G. 1885. Über die innere Organisation einiger silurischer Cephalopoden. Palaeontologische Abhandlungen 3 (1): 1-27.

Holm G. 1891. Om mynningen hos Lituites Breyn. Geologiska Föreningen i Stockholm Förhandlingar 13: 736-780. https://doi.org/10.1080/11035899109445850

Hucke K. 1967. Einführung in die Geschiebeforschung (Sedimentärgeschiebe). Nederlandse Geogologische Vereiniging, Oldenzaal.

Hyatt A. 1894. Phylogeny of an acquired characteristic. Proceedings of the American Philosophical Society 32: 349-647. https://doi.org/10.5962/bhl.title.59826

Jaanusson V. 1960. The Viruan (Middle Ordovician) of Öland. Bulletin of the Geological Institutions of the University of Uppsala 38: 207-288.

Jaanusson V. 1963. Lower and middle Viruan (Middle Ordovician) of the Siljan district. Bulletin of the Geological Institutions of the University of Uppsala 42: 1-41.

Jaanusson V. 1973. Aspects of carbonate sedimentation in the Ordovician of Baltoscandia. Lethaia 6: 11-34. https://doi.org/10.1111/j.1502-3931.1973.tb00871.x

Jaanusson V. 1976. Faunal dynamics in the Middle Ordovician (Viruan) of Balto-Scandia. In: Bassett M.G. (ed.) The Ordovician System: Proceedings of a Palaeontological Association Symposium: 301326. University of Wales Press, Cardiff.

Jaanusson V. 1982. Introduction to the Ordovician of Sweden, Field Excursion Guide. IVth International Symposium on the Ordovician System. Paleontological Contributions from the University of Oslo: 1-9.

Jaanusson V. \& Mutvei H. 1953. Stratigraphie und Lithologie der unterordovizischen Platyurus-Stufe im Siljan-Gebiet, Dalarna. Bulletin of the Geological Institutions of the University of Uppsala 35: 7-39.

King A.H. 1990. Lower and Middle Ordovician Cephalopoda of Baltoscandia. University of Wales, Swansea.

King A.H. 1999. A review of Volkhovian and Kundan (Arenig-Llanvirn) nautiloids from Sweden. In: Olóriz F. \& Rodríguez-Tovar F.J. (eds) Advancing Research on Living and Fossil Cephalopods: 137159. Kluwer Academic-Plenum Publishers, New York. https://doi.org/10.1007/978-1-4615-4837-9_11

King A.H. \& Evans D.H. 2019. High-level classification of the nautiloid cephalopods: a proposal for the revision of the Treatise Part K. Swiss Journal of Palaeontology 138: 65-85.

https://doi.org/10.1007/s13358-019-00186-4 
Klug C. 2007. Sublethal injuries in Early Devonian cephalopod shells from Morocco. Acta Palaeontologica Polonica 52: 749-759.

Klug C., Korn D., Landman N.H., Tanabe K., De Baets K. \& Naglik C. 2015. Describing ammonoid conchs. In: Klug C., Korn D., De Baets K., Kruta I. \& Mapes R.H. (eds) Ammonoid Paleobiology: from Macroevolution to Paleogeography, Topics in Geobiology 44: 3-24. Springer, Dordrecht. https://doi.org/10.1007/978-94-017-9630-9_1

Korn D. 2010. A key for the description of Palaeozoic ammonoids. Fossil Record 13: 5-12. https://doi.org/10.1002/mmng.200900008

Korn D. \& Klug C. 2003. Morphological pathways in the evolution of Early and Middle Devonian ammonoids. Paleobiology 29: 329-348.

https://doi.org/10.1666/0094-8373(2003)029<0329:MPITEO >2.0.CO;2

Kröger B. 2004a. Large shell injuries in Middle Ordovician Orthocerida (Nautiloidea, Cephalopoda). GFF 126 (3): 311-316. https://doi.org/10.1080/11035890401263311

Kröger B. 2004b. Revision of Middle Ordovician orthoceratacean nautiloids from Baltoscandia. Acta Palaeontologica Polonica 49: 57-74.

Kröger B. 2006. Early growth-stages and classification of orthoceridan cephalopods of the Darriwillian (Middle Ordovician) of Baltoscandia. Lethaia 39: 129-139. https://doi.org/10.1080/00241160600623749

Kröger B. 2008. Nautiloids before and during the origin of ammonoids in a Siluro-Devonian section in the Tafilalt, Anti-Atlas, Morocco. Special Papers in Palaeontology 79: 1-110.

Kröger B. 2012. The "Vaginaten": the dominant cephalopods of the Baltoscandian Mid Ordovician endocerid limestone. GFF 134 (2): 115-132. https://doi.org/10.1080/11035897.2012.691897

Kröger B., Beresi M.S. \& Landing E. 2007. Early orthoceratoid cephalopods from the Argentine Precordillera (Lower-Middle Ordovician). Journal of Paleontology 81: 1266-1283.

https://doi.org/10.1666/06-013.1

Lai C. 1965. Ordovician and Silurian cephalopods from the Hanzhung and Ningkiang of Shenzi. Acta Palaeontologica Sinica 13: 308-342.

Lai C. 1986. On Lituitidae. Bulletin of the Chinese Academy of Geological Sciences 12: 107-126.

Lai C. 1989. Biogeography of the Ordovician cephalopods from China. Journal of Southeast Asian Earth Sciences 3: 125-130. https://doi.org/10.1016/0743-9547(89)90016-0

Lindskog A. \& Eriksson M.E. 2017. Megascopic processes reflected in the microscopic realm: sedimentary and biotic dynamics of the Middle Ordovician "orthoceratite limestone" at Kinnekulle, Sweden. GFF 139 (3): 163-183. https://doi.org/10.1080/11035897.2017.1291538

Lindskog A., Eriksson M.E., Tell C., Terfelt F., Martin E., Ahlberg P., Schmitz B. \& Marone F. 2015. Mollusk maxima and marine events in the Middle Ordovician of Baltoscandia. Palaeogeography, Palaeoclimatology, Palaeoecology 440: 53-65. https://doi.org/10.1016/j.palaeo.2015.08.018

Lindskog A., Costa M., Rasmussen C.Ø., Connelly J. \& Eriksson M. 2017. Refined Ordovician timescale reveals no link between asteroid breakup and biodiversification. Nature Communications 8: 1-8. https://doi.org/10.1038/ncomms14066

Lindskog A., Eriksson M.E., Rasmussen J.A., Dronov A. \& Rasmussen C.M.Ø. 2020. Middle Ordovician carbonate facies development, conodont biostratigraphy and faunal diversity patterns at the Lynna River, northwestern Russia. Estonian Journal of Earth Sciences 69: 37-61.

https://doi.org/10.3176/earth.2020.03 
Lindström M. 1971. Vom Anfang, Hochstand und Ende eines Epikontinentalmeeres. Geologische Rundschau 60: 419-438. https://doi.org/10.1007/BF02000464

Lindström M. 1979. Diagenesis of Lower Ordovician hardgrounds in Sweden. Geologica et Palaeontologica 13: 9-30.

Lossen C. 1860. Über einige Lituiten. Zeitschrift der deutschen geologischen Gesellschaft 12: 15-28.

Maletz J. \& Schöning H. 2017. Graptolites from glacial erratics of the Laerheide area, northern Germany. PalZ 91: 223-235. https://doi.org/10.1007/s12542-017-0345-9

Malinky J.M. 2007. Hyolitha from the Early Paleozoic glacial erratic boulders (Geschiebe) of Germany and Poland. Fossil Record 10: 71-90. https://doi.org/10.1002/mmng.200600020

Manda Š. 2008. Trocholites Conrad, 1838 (Nautiloidea, Tarphycerida) in the Middle Ordovician of the Prague Basin and its palaeobiogeographical significance. Bulletin of Geosciences 83: 327-334. https://doi.org/10.3140/bull.geosci.2008.03.327

Marek J. 1999. Ordovician cephalopods of the Prague Basin (Barrandian area, Czech Republic): a review. Acta Universitatis Carolinae - Geologica 43: 413-416.

Meidla T., Ainsaar L. \& Hints O. 2014. The Ordovician System in Estonia. $4^{\text {th }}$ Annual Meeting of IGCP 591, Estonia, 10-19 June 2014. Abstracts and Field Guide: 116-122. University of Tartu, Tartu.

Modéer A. 1796. Slägtet Rörkamring, Orthocera. Svenska Vetenskaps-Akademiens Handlingar, Stockholm.

Mutvei H. 2002. Connecting ring structure and its significance for classification of the orthoceratid cephalopods. Acta Palaeontologica Polonica 47: 157-168.

Neben W. \& Krueger H.-H. 1971. Fossilien ordovizischer Geschiebe. Staringia 1: 1-50.

Neben W. \& Krueger H.-H. 1973. Fossilien ordovizischer und silurischer Geschiebe. Staringia 2: 51109.

Noetling F. 1882. Ueber Lituites lituus Montfort. Zeitschrift der deutschen geologischen Gesellschaft 34: $156-192$.

Noetling F. 1884. Beiträge zur Kenntniss der Cephalopoden aus Silurgeschieben der Provinz OstPreussen. Jahrbuch der Königlich Preussischen Geologischen Landesanstalt und Bergakademie zu Berlin 1883: 101-135.

Nõlvak J., Hints O. \& Männik P. 2006. Ordovician timescale in Estonia: recent developments. Proceedings of the Estonian Academy of Sciences, Geology 55: 95-108. https://doi.org/10.3176/geol.2006.2.02

Pärnaste H. \& Bergström J. 2013. The asaphid trilobite fauna: its rise and fall in Baltica. Palaeogeography, Palaeoclimatology, Palaeoecology 389: 64-77. https://doi.org/10.1016/j.palaeo.2013.06.007

Pärnaste H., Bergström J. \& Zhiyi Z. 2013. High resolution trilobite stratigraphy of the Lower-Middle Ordovician Öland Series of Baltoscandia. Geological Magazine 150: 509-518.

https://doi.org/10.1017/S0016756812000908

Patrunky H. 1926. Die Geschiebe der silurischen Orthocerenkalke. Paläontologischer Teil. Cephalopoden. Zeitschrift für Geschiebeforschung 2: 97-127.

Pohle A., Klug C., Toom U. \& Kröger B. 2019. Conch structures, soft-tissue imprints and taphonomy of the Middle Ordovician cephalopod Tragoceras falcatum from Estonia. Fossil Imprint 75: 70-78.

https://doi.org/10.2478/if-2019-0006 
Pohle A., Kröger B., Warnock R.C.M., King A.H., Evans D.H., Aubrechtová M., Cichowolski M., Fang X. \& Klug C. In press. Bayesian phylogenetic inference of Cambrian-Ordovician nautiloid cephalopods - a lesson on posterior clade supports in fossil datasets. BMC Biology.

Qi D. 1980. Ordovician cephalopods from Wuwei of Anhui and their stratigraphical significance. Acta Palaeontologica Sinica 19: 245-261.

Rasmussen C.M., Nielsen A.T. \& Harper D.A. 2009. Ecostratigraphical interpretation of lower Middle Ordovician East Baltic sections based on brachiopods. Geological Magazine 146: 717-731. https://doi.org/10.1017/S0016756809990148

Remelé A. 1880. Ueber einige neue oder seltene Versteinerungen aus silurischen Diluvialgeschieben der Gegend von Eberswalde. Festschrift für die Fünfzigjährige Jubelfeier der Forstakademie Eberswalde: 179-252. Julius Springer, Berlin

Remelé A. 1881. Strombolituites, eine neue Untergattung der perfecten Lituiten, nebst Bemerkungen über die Cephalopoden-Gattung Ancistroceras Boll. Zeitschrift der deutschen geologischen Gesellschaft 33: $187-195$.

Remelé A. 1882. Ueber einige gekrümmte untersilurische Cephalopoden. Zeitschrift der deutschen geologischen Gesellschaft 34: 116-138.

RemeléA. 1883. Untersuchungenüber die versteinerungsführenden Diluvialgeschiebe des norddeutschen Flachlandes, mit besonderer Berücksichtigung der Mark Brandenburg. I. Stück. Allgemeine Einleitung der älteren baltischen Sedimentgebilde. Untersilurische gekrümmte Cephalopoden. 1. Lieferung. Julius Springer, Berlin.

Remelé A. 1886. Systematic der Lituiten. Zeitschrift der deutschen geologischen Gesellschaft 38: 467468.

RemeléA. 1890. Untersuchungenüber die versteinerungsführenden Diluvialgeschiebe des norddeutschen Flachlandes mit besonderer Berücksichtigung der Mark Brandenburg. Springer, Berlin, Heidelberg. https://doi.org/10.1007/978-3-662-32621-3

Rüdiger H. 1889. Über die Silur-Cephalopoden aus den mecklenburgischen Diluvialgeschieben. Philosophische Facultät, Universität Rostock, Güstrow, Rostock.

https://doi.org/10.5962/bhl.title.14078

Sá A.A. \& Gutiérrez-Marco J.C. 2009. Middle Ordovician cephalopods from the Valongo Formation, northern Portugal. Geogaceta 47: 9-12.

Schindewolf O.H. 1942. Evolution im Lichte der Paläontologie. Bilder aus der Stammesentwicklung der Cephalopoden. Jenaische Zeitschrift für Medizin und Naturwissenschaft 75: 324-386.

Schmitz B., Lindström M., Asaro F. \& Tassinari M. 1996. Geochemistry of meteorite-rich marine limestone strata and fossil meteorites from the Lower Ordovician at Kinnekulle, Sweden. Earth and Planetary Science Letters 145: 31-48. https://doi.org/10.1016/S0012-821X(96)00205-1

Sendino C. \& Bochmann M.M. 2021. An exceptionally preserved conulariid from Ordovician erratics of Northern European Lowlands. PalZ: 1-14. https://doi.org/10.1007/s12542-020-00534-7

Sweet W.C. 1958. The Middle Ordovician of the Oslo region, Norway. 10. Nautiloid cephalopods. Norsk Geologisk Tidsskrift 38: 1-176.

Teichert C. 1964. Doubtful taxa. In: Moore R.C. (ed.) Treatise on Invertebrate Paleontology: K484K490. The Geological Society of America and The University of Kansas Press, Lawrence, KS.

Tinn O. \& Meidla T. 2001. Middle Ordovician ostracods from the Lanna and Holen limestones, southcentral Sweden. GFF 123 (3): 129-136. https://doi.org/10.1080/11035890101233129 
Tinn O., Meidla T. \& Ainsaar L. 2006. Arenig (Middle Ordovician) ostracods from Baltoscandia: fauna, assemblages and biofacies. Palaeogeography, Palaeoclimatology, Palaeoecology 241: 492-514. https://doi.org/10.1016/j.palaeo.2006.05.002

Toom U., Vinn O. \& Hints O. 2019. Ordovician and Silurian ichnofossils from carbonate facies in Estonia: a collection-based review. Palaeoworld 28: 123-144. https://doi.org/10.1016/j.palwor.2018.07.001

Torsvik T.H. \& Cocks L. 2017. Ordovician. In: Torsvik T.H. \& Cocks L. (eds) Earth History and Palaeogeography: 101-123. Cambridge University Press, Cambridge.

https://doi.org/10.1017/9781316225523.007

Troedsson G.T. 1931. Studies on Baltic fossil cephalopods. I. On the nautiloid genus Orthoceras. Lund Universitets Arsskrift, N.F., Avd. 2 27: 1-36.

Wahlenberg G. 1818. Petrificata telluris Suecana. Uppsala, p. 83.

Wahlenberg G. 1821. Petrificata telluris Suecana examinata a Georgio Wahlenberg. Svecanae. Nova Acta Regiae societatis Scientarum Upsaliensis 8: 1-116.

Walch J.E.I. 1771. Die Naturgeschichte der Versteinerungen: zur Erläuterung der Knorrischen Sammlung von Merkwürdigkeiten der Natur. Dritter Theil. Felßecker, Nürnberg.

Woodward S.P. 1856. On an Orthoceras from China. The Quarterly Journal of the Geological Society of London 12: 378-381. https://doi.org/10.1144/GSL.JGS.1856.012.01-02.48

Wu R.C., Calner M., Lehnert O., Lindskog A. \& Joachimski M. 2018. Conodont biostratigraphy and carbon isotope stratigraphy of the Middle Ordovician (Darriwilian) Komstad Limestone, southern Sweden. GFF 140 (1): 44-54. https://doi.org/10.1080/11035897.2018.1435561

Xiao C., Chen Z., Liu L. \& He Y. 2006. Ordovician cephalopod biofacies of South China and its provincialization. Journal of China University of Geosciences 17: 221-230.

https://doi.org/10.1016/S1002-0705(06)60031-9

Zhuravleva F.A. 1961. On rare types of cameral deposits of Devonian nautiloids. Paleontologiceskij Zhurnal 1: 89-94.

Manuscript received: 31 August 2021

Manuscript accepted: 15 November 2021

Published on: 8 March 2022

Topic editor: Christian de Muizon

Desk editor: Pepe Fernández

Printed versions of all papers are also deposited in the libraries of the institutes that are members of the EJT consortium: Muséum national d'histoire naturelle, Paris, France; Meise Botanic Garden, Belgium; Royal Museum for Central Africa, Tervuren, Belgium; Royal Belgian Institute of Natural Sciences, Brussels, Belgium; Natural History Museum of Denmark, Copenhagen, Denmark; Naturalis Biodiversity Center, Leiden, the Netherlands; Museo Nacional de Ciencias Naturales-CSIC, Madrid, Spain; Real Jardín Botánico de Madrid CSIC, Spain; Zoological Research Museum Alexander Koenig, Bonn, Germany; National Museum, Prague, Czech Republic.

\section{Supplementary material}

Supp. file 1. List of specimens investigated in this study. https://doi.org/10.5852/ejt.2022.799.1681.6157

Supp. file 2. Complete measurements table of the specimens investigated in this study. https://doi.org/10.5852/ejt.2022.799.1681.6159 